\title{
SOCIAL SCIENCE RESEARCH FUND:
}

International Literature Review:

Attitudes, Behaviours, Knowledge and

Education - Drugs in Sport: Past, Present and Future

Prepared for

World Anti-Doping Agency

By the

Carnegie Research Institute leeds metropolitan university 
The following members of Leeds Metropolitan University have contributed to the literature review

Dr Susan Backhouse

Prof. Jim McKenna

Prof. Simon Robinson

Mr Andrew Atkin 
WADA

LITERATURE REVIEW

Table of Contents

1 EXECUTIVE SUMMARY 1

$\begin{array}{llr}1.1 & \text { Introduction } & 1\end{array}$

$\begin{array}{lll}1.2 & \text { The Literature Review Methodology } & 1\end{array}$

$\begin{array}{lll}1.3 & \text { The Findings } & 1\end{array}$

$\begin{array}{llr}1.4 & \text { Conclusion } & 2\end{array}$

1.5 Recommendations 2

2 INTRODUCTION 3

2.1 Who is the review of literature for? 3

2.2 The aims and objectives of the review of literature 3

$\begin{array}{lll}2.3 & \text { Search strategy } & 4\end{array}$

2.4 Data sources 4

$2.5 \quad$ Hierarchy of research evidence 4

$2.6 \quad$ Report structure $\quad 5$

$3 \quad$ PRECIPITATING FACTORS 6

$\begin{array}{llc}3.1 & \text { Summary } & 6\end{array}$

$\begin{array}{lll}3.2 & \text { Background } & 6\end{array}$

$\begin{array}{lll}3.3 & \text { Sample } & 6\end{array}$

$\begin{array}{lll}3.4 & \text { Methods } & 7\end{array}$

$\begin{array}{llr}3.5 & \text { Findings } & 8\end{array}$

$\begin{array}{lll}3.6 & \text { Discussion } & 14\end{array}$ 
$\begin{array}{llr}4.1 & \text { Detailed Analysis - Elite Athletes } & 17\end{array}$

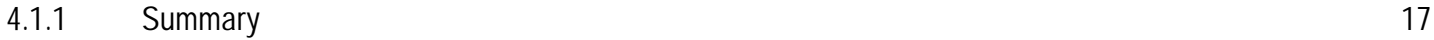

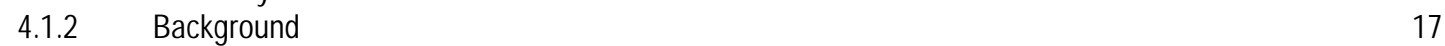

$\begin{array}{llr}4.1 .3 & \text { Sample } & 18\end{array}$

$\begin{array}{ll}\text { 4.1.4 Methods } & 18\end{array}$

$\begin{array}{ll}\text { 4.1.5 Findings: Prevalence and reasons for doping } & 19\end{array}$

$\begin{array}{ll}\text { 4.1.6 Findings: Knowledge of doping } & 20\end{array}$

4.1.7 Findings: Attitudes towards doping prevention, testing and education 21

$\begin{array}{lll}4.1 .8 & \text { Discussion } & 27\end{array}$

4.2 Detailed Analysis - College Athletes 29

$\begin{array}{lll}4.2 .1 & \text { Summary } & 29\end{array}$

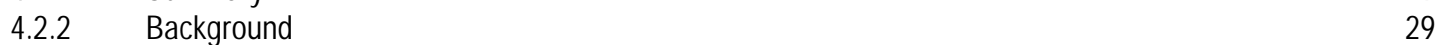

$\begin{array}{lr}4.2 .3 \text { Sample } & 29\end{array}$

$\begin{array}{lll}4.2 .4 & 30\end{array}$

4.2.5 Findings: Framing the issue - the prevalence of drug use 30

$\begin{array}{ll}\text { 4.2.6 Findings: Attitudes towards doping } & 31\end{array}$

$\begin{array}{lll}\text { 4.2.7 Findings: Attitudes toward mandatory drug testing } & 34\end{array}$

4.2.8 Findings: Attitudes towards the efficacy of the drug testing system 36

4.2.9 Discussion 43

$\begin{array}{lll}4.3 & \text { Detailed Analysis - School Children } & 45\end{array}$

$\begin{array}{lll}4.3 .1 & \text { Summary } & 45\end{array}$

$\begin{array}{ll}4.3 .2 & \text { Background }\end{array}$

$\begin{array}{lr}4.3 .3 & \text { Sample }\end{array}$

$\begin{array}{lll}4.3 .4 & \text { Methods } & 46\end{array}$

$\begin{array}{ll}\text { 4.3.5 } & \text { Findings: Prevalence and reasons for doping }\end{array}$

$\begin{array}{lll}\text { 4.3.6 Findings: Attitudes towards doping } & 47\end{array}$

4.3.7 Findings: Beliefs regarding the effects of doping 48

$\begin{array}{ll}4.3 .8 & \text { Discussion }\end{array}$

4.4 Detailed Analysis - Bodybuilders, Powerlifters \& Gym users $\quad 54$

$\begin{array}{lll}4.4 .1 & \text { Summary } & 54\end{array}$

$\begin{array}{ll}4.4 .2 & \text { Background } \\ 4.4 .3 & 54\end{array}$

$\begin{array}{ll}4.4 .3 \text { Sample } & 55\end{array}$

4.4.4 Methods $\quad 55$

$\begin{array}{lll}\text { 4.4.5 } & \text { Findings: Reasons for doping (anabolic steroids) } & 57\end{array}$

4.4.6 Findings: Beliefs regarding the effects of doping (anabolic steroids) 57

4.4.7 Findings: Attitudes towards doping prevention and testing 58

$\begin{array}{ll}\text { 4.4.8 Findings: Attitudes towards other users and physicians } & 59\end{array}$

$\begin{array}{ll}4.4 .9 & \text { Discussion }\end{array}$

$\begin{array}{lll}\text { 4.5 Detailed Analysis - Medical Professionals } & 67\end{array}$

$\begin{array}{lll}4.5 .1 & \text { Summary } & 67\end{array}$

$\begin{array}{lll}\text { 4.5.2 } & \text { Background } & 67\end{array}$

$\begin{array}{lll}4.5 .3 & \text { Sample } & 68\end{array}$

$\begin{array}{ll}\text { 4.5.4 Methods } & 68\end{array}$

$\begin{array}{lll}\text { 4.5.5 Findings: Contact with Doping } & 69\end{array}$

$\begin{array}{ll}\text { 4.5.6 Findings: Knowledge of doping } & 69\end{array}$

$\begin{array}{ll}\text { 4.5.7 Findings: Attitudes towards doping } & 70\end{array}$

$\begin{array}{ll}4.5 .8 & \text { Discussion }\end{array}$ 
$\begin{array}{lll}4.6 & \text { Detailed Analysis - Coaches and support staff } & 76\end{array}$

$\begin{array}{lll}4.6 .1 & \text { Summary } & 76\end{array}$

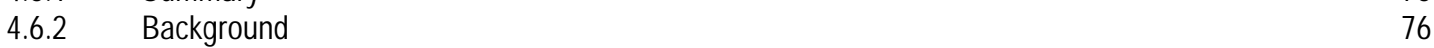

$\begin{array}{lll}4.6 .3 & \text { Sample } & 77\end{array}$

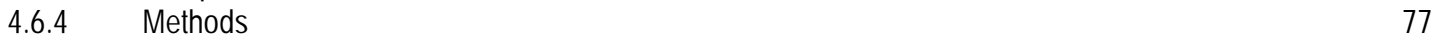

$\begin{array}{lll}\text { 4.6.5 Findings: Contact with doping } & 78\end{array}$

$\begin{array}{lll}\text { 4.6.6 Findings: Beliefs regarding the effects of doping } & 78\end{array}$

$\begin{array}{lll}\text { 4.6.7 Findings: Attitudes toward doping prevention } & 79\end{array}$

4.6.8 Findings: Attitudes towards testing and education $\quad 80$

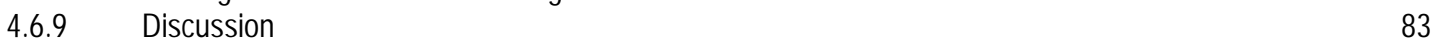

$\begin{array}{llr}\text { 4.7 Detailed Analysis - General Public } & 85\end{array}$

$\begin{array}{ll}\text { 4.7.1 Background } & 85\end{array}$

$\begin{array}{llr}4.7 .2 & \text { Sample } & 85\end{array}$

$\begin{array}{lll}4.7 .3 & \text { Method } & 85\end{array}$

$\begin{array}{lll}4.7 .4 & \text { General Findings } & 86\end{array}$

$\begin{array}{lll}4.7 .5 & \text { Discussion } & 88\end{array}$

$\begin{array}{llr}4.8 & \text { Attitudes section overview and synopsis } & 89\end{array}$

$\begin{array}{llr}4.8 .1 & \text { Background } & 89\end{array}$

$\begin{array}{llr}4.8 .2 & \text { Sample } & 89\end{array}$

$\begin{array}{ll}4.8 .3 \quad \text { Methods } & 90\end{array}$

$\begin{array}{lll}4.8 .4 & \text { Discussion } & 90\end{array}$

$\begin{array}{ll}\text { 4.8.5 } & \text { Attitude research limitations }\end{array}$

$5 \quad$ EDUCATION AND INTERVENTION PROGRAMMES 95

$\begin{array}{llr}5.1 & \text { Background } & 95\end{array}$

$\begin{array}{llr}5.2 & \text { Sample } & 95\end{array}$

$\begin{array}{llr}5.3 & \text { Design } & 95\end{array}$

$\begin{array}{llr}5.4 & \text { Intervention Components } & 97\end{array}$

$\begin{array}{llr}5.5 & \text { Effectiveness } & 98\end{array}$

$\begin{array}{llr}5.6 & \text { Discussion } & 101\end{array}$

6 MODELS OF PERFORMANCE ENHANCING DRUG USE 103

$\begin{array}{llr}\text { 6.1 } & \text { The Drugs in Sport Deterrence Model (DSDM) } & 103\end{array}$

$\begin{array}{llr}6.2 & \text { Drug compliance in sport: A conceptual framework } & 105\end{array}$

$\begin{array}{llr}6.3 & \text { Discussion } & 106\end{array}$

$\begin{array}{lll}\text { 6.3.1 Model comparisons } & 106\end{array}$

$\begin{array}{ll}\text { 6.3.2 } & \text { Models in practice } \\ 6.3 .3 & 107\end{array}$

$\begin{array}{ll}\text { 6.3.3 } & \text { Model development agenda } \\ \end{array}$ 
7 DRUGS AND VALUES: AN ETHICAL REFLECTION OF THE LITERATURE

7.2 An ethical reflection of selected papers

7.6 Discussion.

8 RECOMMENDATIONS FOR FUTURE RESEARCH

8.1 Research methodology

8.2 Target groups

8.3 Education

REFERENCES:

APPENDIX A: ANNOTATED BIBLIOGRAPHY

APPENDIX B: SEARCH STRATEGY

APPENDIX C: ETHICAL DECISION MAKING FRAMEWORK 


\section{List of Figures}

\begin{tabular}{|c|l|}
\hline Figure & Title \\
\hline 1 & Theories of Reasoned Action and Planned Behaviour. \\
\hline 2 & The Drugs in Sport Deterrence Model (DSDM). \\
\hline 3 & Drug compliance in sport conceptual framework. \\
\hline 4 & An overview of the electronic search. \\
\hline
\end{tabular}

\section{List of Tables}

\begin{tabular}{|c|l|}
\hline Table & Title \\
\hline 1 & Hierarchy of research evidence. \\
\hline 2 & $\begin{array}{l}\text { Descriptive analysis of studies that employed regression analysis to identify variables } \\
\text { were predictive of performance enhancing drug use. }\end{array}$ \\
\hline 3 & $\begin{array}{l}\text { Descriptive analysis of studies examining the attitudes of elite athletes towards doping in } \\
\text { sport. }\end{array}$ \\
\hline 4 & $\begin{array}{l}\text { Descriptive analysis of studies examining the attitudes of college athletes towards doping in } \\
\text { sport. }\end{array}$ \\
\hline 5 & $\begin{array}{l}\text { Descriptive analysis of studies examining the attitudes of school age children/athletes } \\
\text { towards doping in sport. }\end{array}$ \\
\hline 6 & $\begin{array}{l}\text { Descriptive analysis of studies examining the attitudes of bodybuilders, powerlifters and } \\
\text { gym-users towards doping in sport. }\end{array}$ \\
\hline 7 & $\begin{array}{l}\text { Descriptive analysis of studies examining the attitudes of the medical profession towards } \\
\text { doping in sport. }\end{array}$ \\
\hline 8 & $\begin{array}{l}\text { Descriptive analysis of studies examining the attitudes of coaches and support staff towards } \\
\text { doping in sport. }\end{array}$ \\
\hline 9 & $\begin{array}{l}\text { Descriptive analysis of studies examining the attitudes of the general public towards doping } \\
\text { in sport. }\end{array}$ \\
\hline 10 & Empirical studies examining knowledge, attitudes and beliefs. \\
\hline 11 & \begin{tabular}{l} 
Descriptive analysis of the key findings from doping intervention programmes. \\
\hline
\end{tabular} \\
\hline
\end{tabular}




\section{EXECUTIVE SUMMARY}

\subsection{Introduction}

1.1.1 The World Anti-Doping Agency (WADA) promotes, coordinates and monitors the global fight against doping in sport. This review is the result of WADA's identification of education and social science research as strategic priorities for developing evidence-based anti-doping education programs and interventions.

1.1.2 Based upon the need identified by WADA, the review provides an extensive annotated bibliography of peer reviewed publications in the social sciences regarding (a) predictors and precipitating factors in doping; (b) attitudes and behaviours towards doping and (c) anti-doping education or prevention programs. The database created during this review should be maintained so that future research in this area can be centrally documented and recorded.

\subsection{The Literature Review Methodology}

1.2.1 The review was conducted in line with guidelines devised by the UK National Health Service Centre for Reviews and Dissemination. An extensive search of the literature was conducted using electronic resources, including, but not limited to, PubMed, Ingenta, Academic Search Elite and ZETOC. The search strategy employed keywords for drug use in sport: 'doping', 'performanceenhancing drugs' and 'drugs AND sport' combined with selected terms relating to specific areas of interest:

i) 'attitudes', 'beliefs', 'knowledge', 'perspectives', 'opinions'.

ii) 'correlates', 'determinants', 'risk factors', 'precipitating factors'.

iii) 'education', 'intervention', 'model', 'prevention'.

1.2.2 The review was limited to peer-reviewed articles written in the English language and published

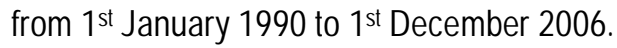

\section{$1.3 \quad$ The Findings}

1.3.1 One hundred and three articles met the inclusion criteria and were considered in this review. Of these, 69 articles considered the attitudes of various target groups, 18 studies sought to examine the precipitating factors and correlates of performance enhancing drug use and 16 articles presented the findings of education intervention studies or model development in relation to doping in sport.

1.3.2 The United States dominated the literature surveyed across attitudes, precipitating factors and education, providing $61 \%$ of the empirical research output examined. 
1.3.3 Attitudinal research is largely descriptive and typically fails to establish causal relationships between attitudes and behaviour. With few exceptions most research is under-theorised. Crosssectional designs, which are categorised as level III in the hierarchy of research evidence, dominate and self-report questionnaires feature in over $97 \%$ of the reported studies. The majority of surveys administered were not subject to psychometric testing, which undermines the validity and reliability of the findings.

1.3.4 Understanding of the precipitating factors for drug use is dominated by studies focused on anabolic steroids among young people. A wide range of factors have been identified although few are seriously helpful in addressing the complex way in which drug use begins, is sustained or stops. More recent studies have begun to explore the complex social matrix within which drug use becomes established. In this process researchers are increasingly acknowledging that like other behaviours, drug use follows a process and is more than an all-or-nothing behaviour. It is likely that the direction taken by Public Health research - in terms of addressing the interplay of motivation, context and skills - will represent the next generation of research design with drug prevention.

1.3.5 Education and intervention research are limited by both their span and scale. The limits of the chosen research designs restrict the capacity to transfer findings across settings, populations or communities. Randomised controlled trials represent the highest standard of research evidence and there is a need for more studies based on this design to confirm 'which works best'. Importantly, within these designs, 'best bet' intervention approaches should be compared. In this way, trials will be able to establish the everyday value of intervention approaches.

\subsection{Conclusion}

The evidence presented in this review leads to a simple conclusion: the weak evidence base undermines strategic planning and limits the capacity to target appropriate and efficacious education programmes to abate doping in sport.

\subsection{Recommendations}

This review has highlighted a number of key priorities in the social science research field. For example, adopting a Behavioural Epidemiological Framework would direct research efforts. Employing a variety of research designs from the upper echelons of the evidence hierarchy would facilitate the examination of causality and developing psychometrically sound measurement tools would enhance the validity and reliability of findings. Finally, the collaborative networks between practitioner and researcher need to be established so that evidence based findings inform the strategic planning of interventions and enable effective monitoring and evaluation. 


\section{INTRODUCTION}

This section provides an introduction and background to the review of literature presented hereafter. The World Anti-Doping Agency (WADA) promotes, coordinates and monitors the fight against doping in sport from a global position. Article 19 of the World Anti-Doping Code (WADC) states that the purpose of anti-doping research is to "contribute to the development and implementation of efficient programs within Doping Control and to anti-doping information and education" (p.53). This review of literature is the result of WADA's identification of education and research as strategic priorities, based upon the fact that anti-doping education programs and interventions should emanate from evidence based practice. Therefore, WADA initiated a Social Sciences Research Grant Program in order to encourage research in the social sciences. WADA's objective is to fund research that will enable more efficacious doping prevention strategies and develop a deeper understanding of the factors that lead athletes to commit doping violations in sport. WADA identified this literature review as a priority in the 2006 Call for Bids.

\subsection{Who is the review of literature for?}

This literature review is aimed at the commissioners, doping in sport researchers and providers of anti-doping education programmes and interventions.

\subsection{The aims and objectives of the review of literature}

Based upon the need identified by WADA, the review of literature will provide an extensive annotated bibliography of peer reviewed publications in the social sciences regarding (a) predictors and precipitating factors in doping; (b) attitudes and behaviours towards doping and (c) anti-doping education or prevention programs. More specific aims of the review were:

- To report the key findings and conclusions on:

- Research examining the predictors and precipitating factors involved in doping in sport.

- Research examining the attitudes and behaviours towards doping of various groups. 
- Research examining the efficacy of anti-doping education or prevention programs.

- To highlight both the content and the quality of the available evidence. Given the importance of quality research design, we place the available evidence found following the international literature review within an established hierarchical framework.

- To provide recommendations for future research commissioning based upon a critical reflection of the current approaches and methodologies employed.

\subsection{Search strategy}

We searched for studies that reported beliefs and attitudes of population groups towards doping, precipitating factors and doping correlates and anti-doping education and intervention programmes. The review was conducted in accordance with guidelines devised by the UK National Health Service Centre for Reviews and Dissemination. To establish the need for a review and estimate the number of potentially eligible studies, the lead author conducted scoping searches in August 2005. The main literature search was conducted in April 2006, with a follow up search carried out in the first week of December 2006, to highlight new articles published in the interim.

\subsection{Data sources}

An extensive search of the literature was conducted using the a wide range of databases, including: PubMed, Ingenta, Academic Search Elite, CINAHL, PsycARTICLES, PsycINFO, SPORTDiscus, Web of Science, ZETOC and Library Information Science and Technology Abstracts. Additional publications were identified by reviewing the bibliographies of articles identified through the database search. Among others, the main key words included: 'doping', 'performance-enhancing drugs' and 'drugs AND sport' combined with selected terms relating to specific areas of interest. Further details of the search strategy, including the strategy terms and inclusion criteria are shown in Appendix B.

\subsection{Hierarchy of research evidence}

The following hierarchy of research evidence ${ }^{1}$ has been considered when evaluating the strength of the literature in this field. 
Table 1. Hierarchy of research evidence.

\begin{tabular}{|c|l|}
\hline \multicolumn{2}{|l|}{ Hierarchy of evidence } \\
\hline Level & Type of evidence \\
\hline Ia & $\begin{array}{l}\text { Evidence from systematic reviews or meta analysis of randomised } \\
\text { controlled trials }\end{array}$ \\
\hline Ib & Evidence from at least one randomised controlled trial \\
\hline Ila & Evidence from at least one controlled study without randomisation \\
\hline Ilb & Evidence from at least one other type of quasi experimental study \\
\hline III & $\begin{array}{l}\text { Evidence from non experimental descriptive studies, such as comparative } \\
\text { studies, correlation studies and case control studies }\end{array}$ \\
\hline IV & $\begin{array}{l}\text { Evidence from expert committee reports or opinions and/or clinical } \\
\text { experience of respected authorities }\end{array}$ \\
\hline
\end{tabular}

\subsection{Report structure}

This review is divided into eight sections, with three appendices. Firstly, an executive summary is provided, which synthesises the key findings of the review. Section two presents a brief introduction and rationale for the review, before identifying its main objectives. The third section critically examines the empirical studies that have considered the precipitating factors and correlates of doping in sport. Section four examines the attitudes, knowledge and beliefs of various target groups in relation to drug use in sport and drug testing programmes. Target groups are considered individually and include elite athletes, college athletes and the medical profession. This section follows a standardised format for all target groups, beginning with an overall synopsis of the studies undertaken in this specific field. Section five examines the studies that have investigated anti-doping education programmes and interventions. Section six presents a brief overview of current theoretical models of doping in sport, identified in the literature. The section also considers future model testing. In section six, an ethical and values perspective is offered and key themes from the literature surveyed are identified. Finally, several broad conclusions and future recommendations are included in section seven of the review. The appendices include the annotated bibliography, further details of the search strategy and background information on the ethical reflection. 


\section{PRECIPITATING FACTORS}

\subsection{Summary}

Under this heading are studies that attempted to identify variables that correlated with or predicted the use of performance enhancing drugs. It is important to identify the pre-existing factors that respond to interventions and that predict intervention outcomes. Such factors indicate the action potential of the theoretical models from which they emerge. They also show how well interventions influence the mechanisms that should alter intentions toward, or actual, drug use.

\subsection{Background}

Twenty-one studies were identified that examined correlates, determinants or risk factors associated with the use of performance enhancing substances. Of these, twelve were conducted in the United States 17-19, 31,32,36, 43,57,58,79, 108 and two in France 63,71 , Norway 122,136 , one each in Canada ${ }^{16}$, the Netherlands ${ }^{131}$, Germany 120 and Italy ${ }^{72}$. One study addressed doping among tertiary education students across five EU countries (Finland, France, Germany, Greece, Italy) and Israel 92. Three studies, from the associates of Oregon Health Sciences University $31,36,43$, were focused upon an intervention design, but considered precipitating factors in their analysis. Consequently, these studies are annotated in the education/intervention section (Appendix A) and they are included in the total study numbers for the education/intervention studies, rather than the precipitating factor studies.

\subsection{Sample}

In the largest study the sample was over $1600{ }^{79}$ and the combined total of participants' across all other studies exceeded 15000. Sample size varied from 4918 to $3207^{36}$ and $6402{ }^{63}$, with the largest samples drawn from young athletes typically addressing a wide range of drug and bodyshape related factors. A majority of papers report data collected solely from males $16-19,36,57,58,72$, 108. Of the remaining articles, one provided no gender details 63,122 , one provided no gender profile of respondents ${ }^{136}$, three were male-dominated $32,120,131$, two were based on gendermatched sample 72,92 and one was female-only ${ }^{31}$. Participant ages ranged $14-65$ years, 
though the majority of studies were in people aged 16-30, although no data on age was reported by either Tangen et al ${ }^{122}$ or Elliott et al ${ }^{31}$.

Seven studies recruited samples dominated ( $\geq 65 \%$ ) by a single ethnic group; described as either 'White' 17, 18, 36, 58, 'Caucasian' 108, 'Dutch' 131 or 'Hispanic' 19. Ethnicity data was unreported in studies $16,31,12263,72,73,92,120$. All studies with participants aged 16+ included participants involved in weight-lifting or regular gym use. Weight-lifters or bodybuilders were selected as the sole study population in five studies $17,18,57,58,131$. In the ATLAS study ${ }^{36}$, where adolescents and young people were the focus, American Football provided the context; clearly increased body size, strength and power are important in this sport. Three studies compared responses between bodybuilders and other athletes or non-athletes $16,19,108$. Only Tangen et al ${ }^{122}$ recruited elite athletes (defined as individuals receiving support from the Norwegian Olympic Committee) with gym users and sports students included for comparison. However, participants were grouped according to use or non-use of doping substances, rather than athletic status, so characteristics of elite athletes cannot be isolated.

\subsection{Methods}

Seven studies employed a case-control survey design, recruiting separate samples of drug users and non-users to compare responses on a range of social, psychological and demographic variables $16,17,19,58,79,108,122$. Brower et al ${ }^{18}$ conducted a cross-sectional survey to identify risk factors for dependence among known anabolic steroid users. Vogels et al 131 and Streiegel et al 120 also employed cross-sectional surveys to examine the risk factors and their prevalence for using performance-enhancing drugs among gym users. All such data were based on self-report questionnaires. Burnett and Kleiman ${ }^{19}$ supplemented questionnaire data by conducting structured interviews to corroborate responses.

Most studies focused upon factors associated with the use of anabolic-androgenic steroids 16-19, $57,58,73,108,120$. One study also explored future use of AAS ${ }^{136}$. Tangen et al ${ }^{122}$, Vogels et al 131 and Lucidi et al 72 examined drug use in a broader sense, assessing factors associated with use of a range of performance enhancing drugs including steroids, amphetamines and growth hormones. Papadapolous et al ${ }^{92}$ assessed a range of doping related behaviours (androgens, 
anabolic substances, diuretics, beta-blockers, stimulants etc), based on wide variability of sporting involvement across the samples from respective countries (3-40\%).

Three studies 17, 19, 108 employed instruments devised and validated in previous research and one 58 used elements drawn from established scales. Other studies used questionnaires developed for the specific purposes of that study 18,31,120,122, 131 or modified instruments developed for other projects $16,57,58,79$. Tangen et al 122 drew upon an extensive review of the socio-cultural literature and existing decision-making theories to construct a heuristic model summarising the most important structures and processes informing the decision to use performance enhancing drugs. Based upon this model, a questionnaire was then devised to provide insight into each of these key constructs. Work underpinning the ATLAS ${ }^{36,73}$ and ATHENA ${ }^{31}$ studies has been developed through extensive refinement of population-specific instruments, supported by a growing body of psychometric validation. All studies gathered information that may be summarised under headings of 'psychological', 'social' and 'cultural'. Psychological variables included those relating to body image $16-19,31,36,58,108$, personality ${ }^{19}$, value-orientation ${ }^{122}$, anti-social or behavioural disorders 58,120 and educational discipline ${ }^{92}$. Social and cultural variables were primarily related to patterns and duration of drug use, knowledge and contact with other users and peer and referent group norms 17, 18, 63, 92, 108, 120, 131. Three papers represent interventions $31,36,120$ which provide important information about precipitating factors that lead to involvement. Wichström ${ }^{136}$ provided important and unique prospective data for young Norwegian students based on selfreported questionnaire measures. Participants began the study with an average of 14.9 years, completing it with follow-up measures five years later.

\subsection{Findings}

All studies employed statistical methods to identify significant differences between users and nonusers of performance enhancing drugs. Regression analysis allows researchers to determine the strength of the relationship between performance enhancing drug use $16,18,57,58,92,108,120,131,136$ or dependence ${ }^{17}$ and a range of psycho-social variables. One study identified factors that predicted subsequent drug use ${ }^{136}$. A summary of key findings from those studies that employed regression analysis to identify factors associated with performance enhancing drug use is shown in Table 2. 
Of the studies examining the relationship between body image and drug use (specifically anabolic steroids), six indicated that deficits in body image, such as high body dissatisfaction, drive for bulk I thinness, feeling 'not big enough', preoccupations with body size or bulimia predicted of drug use $16,57,58,131$ 17, 108 or dependence ${ }^{18}$. In contrast, Vogels et al 131 identified no significant relationship between performance enhancing drug use and 'body satisfaction'. Kanayama et al ${ }^{57}$ highlighted that low response variability - often related to narrow stereotypical masculine values limited the capacity to distinguish non-users, experimental users and heavy AAS users.

Other variables that predicted drug use included: knowing other drug users $17,92,131$ not studying biomedicine ${ }^{92}$, illicit drug use, poor paternal relations and childhood conduct disorder ${ }^{58}$. Using standard statistical tests, Tangen et al 122 identified a number of significant differences between self-reported drug users and non-users including value-orientation, sporting and social environment, social position and motives for training. Burnett and Kleiman ${ }^{19}$ reported that adolescent steroid users appear to be relatively similar to non-using peers on a number of personality variables including introversion, inhibition, sociability, confidence, forcefulness, respectfulness and sensitivity as measured using the Millon Adolescent Personality Inventory. Kanayama et al 57 found few variables to distinguish what causes or perpetuates AAS use, although this study was profoundly limited by a small sample size ( $n=89$ men). The hierarchical regression analyses of Miller et al ${ }^{79}$ highlight important protective effects of sport participation on use of other risk behaviours. For example, risky sexual behaviour and rates of suicidal idea/behaviour are lower athlete users of AAS. These protective effects especially benefited males. 
Table 2. Descriptive analysis of studies that employed regression analysis to identify variables that were predictive of performance enhancing drug use.

\begin{tabular}{|c|c|c|c|}
\hline Study & Dependent variable & Independent variables & Outcomes \\
\hline $\begin{array}{l}\text { Blouin and } \\
\text { Goldfield (1995) }\end{array}$ & Anabolic steroid use & $\begin{array}{l}\text { Psychological factors; self-esteem, } \\
\text { ineffectiveness, perfectionism, interoceptive } \\
\text { awareness, interpersonal distrust, maturity } \\
\text { fears, depression. } \\
\text { Body image factors; drive for thinness, } \\
\text { bulimia, body dissatisfaction, drive for bulk. }\end{array}$ & $\begin{array}{l}\text { - Steroid using bodybuilders reported lower self esteem }(-6.5 ; P<0.05) \text {, higher } \\
\text { maturity fears }(+14.2 ; P<0.05) \text { and higher scores on measures for bulimia }(+9.3 \text {, } \\
P<0.01) \text { and drive for bulk }(+5.4 ; P<0.01) \text { than non steroid using bodybuilders. } \\
\text { - Psychological and body image variables predicted steroid use }\left(r^{2}=0.47, P<0.001\right) \text {. } \\
\text { - Significant independent predictors of steroid use were bulimia (beta }=0.28) \text {, drive } \\
\text { for bulk (beta }=0.028 \text { ) and maturity fears (beta }=0.15 \text { ). }\end{array}$ \\
\hline Brower et al (1991) & $\begin{array}{l}\text { Symptoms of anabolic } \\
\text { steroid dependence }\end{array}$ & $\begin{array}{l}\text { Demographic factors; age location, } \\
\text { education, income } \\
\text { Pharmacologic factors; duration of use, } \\
\text { dosage } \\
\text { Psychological factors; positives and } \\
\text { negatives of use, body satisfaction, feelings } \\
\text { of being 'not big enough'. } \\
\text { Physical factors; muscle size and strength, } \\
\text { competition performance, amount lifted, } \\
\text { side effects (acne, alopecia, hirsutism) }\end{array}$ & $\begin{array}{l}\text { - Significant predictors of the number of symptoms of anabolic steroid dependency } \\
\text { were maximum dosage taken and feeling not big enough after taking steroids }\left(r^{2}=\right. \\
0.28, P<0.01) \text {. } \\
\text { - Greater risk of being a steroid user was linked to higher scores for body } \\
\text { dissatisfaction, upper body strength and age }\end{array}$ \\
\hline Brower et al (1994) & Anabolic steroid use & As above & $\begin{array}{l}\text { - Predictors of being a 'high-risk' non-user or a steroid user were student status, } \\
\text { number of non-steroidal substances used for training, 'feeling not big enough' and } \\
\text { weight (goodness of fit } x 2=59.19, P<0.001 \text { ) } \\
\text { - Predictors of being a non-user or a 'high-risk' non-user were 'feeling not big } \\
\text { enough', height and knowing a steroid user (goodness of fit } X 2=38.14, P<0.001 \text { ) }\end{array}$ \\
\hline $\begin{array}{l}\text { Kanayama et al } \\
(2003)\end{array}$ & Anabolic steroid use & $\begin{array}{l}\text { History of nutritional supplement / } \\
\text { performance enhancing drug use, history of } \\
\text { psychiatric or childhood conduct disorder, } \\
\text { Attention Deficit Hyperactivity Disorder, } \\
\text { family and childhood environment. }\end{array}$ & $\begin{array}{l}\text { - AS users were most likely to report poor relations with their father than non using } \\
\text { peers }(P<0.05) \text {. } \\
\text { - Steroid users were also most likely to be diagnosed with childhood conduct } \\
\text { disorder }(P<0.05) \text {. } \\
\text { - Steroid users reported significantly lower self-confidence about bodily appearance } \\
\text { prior to initiating regular gym use }(P<0.05) \text {. } \\
\text { - AS users were more likely to have experienced previous dependence on } 1(+) \text { other } \\
\text { drug (alcohol, cannabis, cocaine). }\end{array}$ \\
\hline
\end{tabular}


Table 2. Descriptive analysis of studies that employed regression analysis to identify variables that were predictive of performance enhancing drug use.

\begin{tabular}{|c|c|c|c|}
\hline Study & Dependent variable & Independent variables & Outcomes \\
\hline $\begin{array}{l}\text { Kanayama et al } \\
(2006)\end{array}$ & $\begin{array}{l}\text { History of anabolic- } \\
\text { androgenic } \\
\text { Steroid use }\end{array}$ & $\begin{array}{l}\text { Self-esteem, Male role attitudes, Eating } \\
\text { Disorder, Body size preoccupation, Muscle } \\
\text { dysmorphia }\end{array}$ & $\begin{array}{l}\text { - Linear/Logistic regression identified that AAS use was associated with body image } \\
\text { pathology; behavioural; measures distinguished current (episodic versus regular) } \\
\text { users; Attitude measures distinguished previous users. } \\
\text { - Heavy users were distinguished from non-users by 'preoccupation with body size' } \\
\text { (OR=15.4, } 95 \% \mathrm{Cl} 1.8 \text { to } 132.1 \text { ) and 'always covers body with clothes' (OR=5.4, } \\
1.5 \text { to } 20.1) \text {. } \\
\text { - Past users were distinguished from non-users by 'preoccupation with body size' } \\
\text { (OR=5.8, } 1.1 \text { to } 30.9 \text { ). } \\
\text { - Body image concerns may be stable traits rather than exclusive states linked to } \\
\text { initial or recent use of AAS. }\end{array}$ \\
\hline Lucidi et al (2004) & $\begin{array}{l}\text { Use of doping } \\
\text { substances }\end{array}$ & $\begin{array}{l}\text { Demographics } \\
\text { Variables drawn from Theory of Planned } \\
\text { Behaviour (attitudes, social norms, } \\
\text { perceived behavioural control) plus 'moral } \\
\text { disengagement' }\end{array}$ & $\begin{array}{l}\text { - TPB theoretical propositions predicting intentions were supported across genders; } \\
\text { the model accounted for } 51 \% \text { of criterion variance. } \\
\text { - Attitudes, followed by subjective norms were the strongest predictors of intention to } \\
\text { use doping substances. } \\
\text { - Moral disengagement and past use of protein supplements influenced behavioural } \\
\text { intention. }\end{array}$ \\
\hline Miller et al (2003) & Use of AAS & $\begin{array}{l}\text { Demographics, risks scales for tobacco, } \\
\text { alcohol, drugs, sex, suicide, athletic status. }\end{array}$ & $\begin{array}{l}\text { - Hierarchical regression analyses were applied to responses from over } 16000 \\
\text { nationally representative high school students (1997 Youth Risk Behaviour } \\
\text { Survey). } \\
\text { - After controlling for race ethnicity and SES significant differences were found for } \\
\text { athlete users (n=291) vs } 360 \text { non-athlete users, who had the lowest suicide risk, } \\
\text { yet female users were more likely to have a higher suicide risk than males. } \\
\text { - In males, but NOT in females, athletic users' sport involvement buffered against } \\
\text { use of illegal substances. Gender was a significant predictor of illicit drug use in } \\
\text { non-athlete AAS users but not among athlete users. }\end{array}$ \\
\hline
\end{tabular}


Table 2. Descriptive analysis of studies that employed regression analysis to identify variables that were predictive of performance enhancing drug use.

\begin{tabular}{|c|c|c|c|}
\hline Study & Dependent variable & Independent variables & Outcomes \\
\hline $\begin{array}{l}\text { Papadopolous et al } \\
(2006)\end{array}$ & $\begin{array}{l}\text { Use of doping } \\
\text { substances }\end{array}$ & $\begin{array}{l}\text { Demographics, academic discipline, other } \\
\text { health-related behaviours, sports } \\
\text { involvement. }\end{array}$ & $\begin{array}{l}\text { - Logistic and multiple logistic regression showed that increased risk for reporting } \\
\text { doping was linked to Males [vs Female] (OR=2.16, } 1.25 \text { to } 3.74) \text {, Participating in a } \\
\text { major sport event [vs not] (OR=1.98, } 1.14 \text { to } 3.46) \text {, Having a doping peer [vs not] } \\
\text { (OR=8.61, } 4.49 \text { to } 16.53 \text { ) and Increasing frequency of drunkenness. In contrast, } \\
\text { Studying medicine [vs not] (OR=0.49, } 0.27 \text { to } 0.89 \text { ) was linked to reduced risk of } \\
\text { doping. }\end{array}$ \\
\hline $\begin{array}{l}\text { Schwerin et al } \\
\text { (1997) }\end{array}$ & Anabolic steroid use & $\begin{array}{l}\text { Social physique anxiety, brief fear of } \\
\text { negative evaluation, body esteem (upper } \\
\text { body), body dissatisfaction, eating } \\
\text { disorders. }\end{array}$ & $\begin{array}{l}\text { - Logistic regression revealed that three variables were significantly related to being } \\
\text { a steroid using bodybuilder: Body dissatisfaction, upper body strength and age } \\
\text { (model } x 2=49.98, P<0.001 \text { ). }\end{array}$ \\
\hline Streigel et al (2006) & $\begin{array}{l}\text { Use of anabolic } \\
\text { ergogenic substances }\end{array}$ & $\begin{array}{l}\text { Demographic factors: Education, Education, } \\
\text { Marital status, Nationality, Religion } \\
\text { Sport factors: Gender, BMI, Weight, Sport, } \\
\text { Weekly training/days, training years, Alcohol } \\
\text { use, Cocaine use }\end{array}$ & $\begin{array}{l}\text { - Logistic regression revealed that only Sport variables predicted being a 'user'. } \\
\text { Strongest predictors were involvement in Body-building (OR=12.4), Training } 3 \text { or } \\
\text { more times/week (OR=8.65) and BMI >23 (OR=6.17). } \\
\text { - Stepwise regression confirmed the positive links of anabolic ergogenic substance } \\
\text { use with greater BMI, previous cocaine use, increased training years and training } \\
\text { frequency. A negative relationship was found for alcohol consumption. }\end{array}$ \\
\hline Vogels et al (1996) & $\begin{array}{l}\text { Performance enhancing } \\
\text { drug use }\end{array}$ & $\begin{array}{l}\text { Individual factors; sex, age, education } \\
\text { status, reasons for gym use, body } \\
\text { satisfaction, interest in drugs } \\
\text { Social / cultural factors; peer group opinions } \\
\text { / beliefs regarding drug use, conformity with } \\
\text { social norms }\end{array}$ & $\begin{array}{l}\text { - The most reliable predictors of use of performance enhancing drugs were 'being } \\
\text { interested' (OR=4.5), 'knowing other users' (OR=4.2), 'non-conformity of the peer } \\
\text { group' (OR=3.0), body building (OR=2.4) and positive conversations with } \\
\text { acquaintances about doping (OR=5.2). }\end{array}$ \\
\hline Wichstrǿm (2006) & $\begin{array}{l}\text { Future use of AAS; } 1994 \\
\text { to } 1999\end{array}$ & $\begin{array}{l}\text { AAS involvement, Involvement in power } \\
\text { sports, Appearance and eating issues, } \\
\text { Problem behaviours, Emotional problems. }\end{array}$ & $\begin{array}{l}\text { - Multivariate logistic regression identified that male gender }(\mathrm{OR}=5.55) \text {, } \\
\text { comparatively younger age }(\mathrm{OR}=0.67) \text {, prior use of } \mathrm{AAS}(\mathrm{OR}=5.02) \text {, involvement } \\
\text { in power sport (OR=3.89) and frequent alcoholic drunkenness }(\mathrm{OR}=14.80) \text { all } \\
\text { predicted future use of AAS }\end{array}$ \\
\hline
\end{tabular}


In German research ${ }^{120}$, use of anabolic ergonomics was predicted by male gender (Odds Ratio $(\mathrm{OR})=5.87,95 \% \mathrm{Cl} 3.30$ to 12.8$)$, greater body mass index $(\mathrm{OR}=6.17,95 \% \mathrm{Cl} 3.49$ to 11.7$)$. Of the possible factors, no social indicators achieved significance whereas all parameters linked to physical fitness were predictors. Involvement in body building provided the strongest Odds Ratio (12.4). Further predictor variables included more frequent training days/week (OR=8.65), training for more than six years $(O R=2.79)$ and use of alcohol and cocaine.

A recent intervention study (Adolescents Training and Learning to Avoid Steroids, ATLAS) assessed the impact of baseline factors for assessing intervention effects in a trial designed to reduce anabolic steroid use in young males (US) ${ }^{36}$. Findings indicated consistent 'baseline $x$ treatment interaction' differences; lower baseline scores for (i) knowledge of the effects of steroid use and (ii) intentions to use steroid were associated with better intervention outcomes.

'Mediation' describes the factors which, when changed, lead to different intervention outcomes. The ATLAS study ${ }^{73}$ emphasised that intentions to use anabolic androgenic steroids (AAS) were mediated (reduced) by a number of factors, including the perceived severity of AAS effect (22\% mediation) and the ability to turn down offers of drugs (14\% mediation). Increasing reasons for using AAS was counterproductive, leading to heightened intention to use AAS. At one year, mediators were perceived severity of AAS effects ( $25 \%$ effect); reasons for using AAS remained counterproductive (15\%).

In another intervention, designed to address drug use in disordered eating and body-shaping in young female athletes (Athletes Targeting Healthy Exercise and Nutrition Alternatives, ATHENA), 11 factors were identified as potential predictors within a randomised controlled trial intervention 31. These were; (a) Disordered eating behaviour and body-shaping drug use; (b) Nutrition and exercise behaviours and abilities; (c) Intentions towards future disordered eating and drug use; (d) Knowledge; Moods, traits and beliefs; (e) Media; Coach and peer effects. Trial effects resulting from $8 \times 40$-minute peer-led sessions showed positive benefits in most factors indicating their amenability to peer-led intervention among female high school athletes. 
Among Italian students, aged 14-20, attitudes were the strongest predictors of doping intentions ${ }^{72}$. Past use of protein supplements was another predictor for doping intentions although only 12 males and no females (from a total sample 952) reported using AAS.

\subsection{Discussion}

Most studies in this field have examined risk factors for anabolic steroid use amongst weight lifters or body builders. More recent studies have increasingly addressed specific precipitating factors for a broad range of drug use in high school athletes and young people up to age 20. Researchers have employed questionnaire methods to assess differences between users and non-users and adopted regression analyses to identify factors that may predict steroid use. The weight of prevailing evidence supports a strong association between body image or body esteem and steroid use amongst weight-lifters and bodybuilders, although these factors often do not consistently distinguish within people training within weightlifting.

A range of social and cultural variables, including contact with other users and behavioural/conduct disorders may also facilitate use of performance enhancing drugs. In one $2 \times 2 \times 2$ study design [gender (2) by users and non-users ( $2 x$ ) and by athletes and non-athletes (2)], authors ${ }^{79}$ speculate that differences that were found may reflect protective effects of athletic involvement. They suggest that sport involvement may narrow the definitions of 'user' that may predominate in the athletic identity, whereas 'drug user' may have wider and more encompassing (and potentially more damaging) notions among non-athletes.

The extent to which existing literature contributes to an understanding of performance enhancing drug use amongst athletes is unclear. Although there is relatively consistent evidence highlighting risk factors for anabolic steroid abuse, the use of samples comprising solely of weight lifters or body builders limits the degree to which findings may be generalised. On the other hand, these studies are justified in that most AAS use seems to be found in groups with experience of weight training.

What may distinguish bodybuilders from other steroid users, including other athletes, is that the goals of bodybuilding pertain to achieving an idealised body shape, the achievement of which is 
determined by visual or aesthetic appraisal. With this in mind, the association between body image and anabolic steroid use in bodybuilders seems valid. For other athletes, however, the impetus lies with training the body to perform a particular task, to run faster or kick further, thus physical appearance may be less important than physical function. The distinction between the use of anabolic steroids for aesthetic reasons and for purposes of improved sporting performance in a more functional sense may be important when seeking to identify factors associated with steroid use. There may be a need to more closely profile the range of variables that combine to increase risk, and that ultimately predict, drug use. Identifying the effects of these different factors in any pathways into - and out of - drug use seems justified.

It is also likely that the motivation for steroid use may, at least partly, derive from sources unrelated to the individual's choice of athletic pursuit, such that personality factors relating to risk taking or sensation seeking may be important. Other potential motivators include curiosity about their effects or a desire for acceptance within a particular social group or environment. Research that seeks to identify factors that motivate steroid use amongst participants from a range of sporting events would shed further light on this issue. Improvements in prediction will result from widening the range of factors that are considered within multivariate analysis. Newer concepts, such as athleteinitiated or athlete-enticed drug use and moral disengagement should be considered for their respective impact. Further, Striegel et al., ${ }^{120}$ has highlighted the important role of support for drug use (by 13.5\% of fitness centre users) within health care systems, presumably under the logic of harm-minimisation. This contrasts with the findings of Papadopolous et al., ${ }^{92}$ who showed the protective effect of studying biomedicine in tertiary students aged $20+$.

Interestingly, the only study that failed to identify an association between body image and drug use 131 was also one of the few studies exploring the broader notion of using performance enhancing drug use, rather than focusing upon a specific substance. However, among the $29 \%$ of females in the total sample only one female identified herself as a steroid user; suggesting that this finding is unlikely to be gender mediated. It is unclear whether risk factors for use vary from one substance to the next, though on the understanding that different drugs may produce different effects and therefore appeal to different audiences, this proposal warrants further investigation. On the basis 
of existing research, it would appear that bodybuilders represent a unique population within the context of drug use, due to the overriding emphasis placed on bodily appearance. 


\section{$4 \quad$ ATTITUDES TOWARDS DOPING}

\subsection{Detailed Analysis - Elite Athletes}

\subsubsection{Summary}

Doping scandals appear to be common place in the national and international media. A number of high profile athletes have engaged in doping behaviours and have consequently been banned from competition. The resulting headlines tarnish high-level sport and impact upon the perceived climate of elite sport. Furthermore, the subsequent handling of such cases can impact upon the attitudes of elite athletes. However, it is disappointing to note that limited research has been published on this high profile group, not least because they are arguably subject to the most stringent drug testing programmes.

Self-report questionnaires suggest that elite athletes generally hold negative attitudes towards doping in sport and support the drug testing programmes currently in place in their sports. Indeed, the majority of this group indicates that they would welcome further education initiatives to better inform them of doping issues. However, methodological limitations cloud the findings and the heterogeneous nature of the research methodologies employed limit the capacity to synthesise the evidence to arrive at firm conclusions. The account that follows reflects the main findings of peer-reviewed published articles that report more than prevalence statistics by offering information on elite athletes' knowledge of, and attitudes towards doping and drug testing systems.

\subsubsection{Background}

Fourteen peer-reviewed published papers, were identified that examined the knowledge and attitudes of elite and/or competitive athletes in relation to doping $6,8,11,12,21,67,77,85,88,94,103,114,121$, 133. Articles were retrieved from a range of countries; four from the UK 21, 77, 114, 133, two from France 67,94 and Australia ${ }^{11,12}$ and one each from Cameroon ${ }^{8}$, Finland ${ }^{6}$, Germany ${ }^{121}$, Italy 103 , Nigeria ${ }^{85}$, and Turkey ${ }^{88}$. Eleven studies examined attitudes towards all classes of doping and/or recreational drugs $6,8,11,67,77,94,103,114,121,133$ whilst two focused specifically upon anabolic steroids ${ }^{12,85}$. Two further studies 26,134 were identified that explored the attitudes and knowledge 
of elite powerlifters. However, for completeness these studies were analysed in the bodybuilding/powerlifting section (section 4.5). A brief descriptive analysis of each study can be found in Table 3 and a detailed annotation in Appendix A.

\subsubsection{Sample}

Across the fourteen papers, sample size varied from $1277-1231^{103}$, with a mean of 428 subjects per study. However, the Scarpino et al. ${ }^{103}$ study was a mixed sample and in addition to elite athletes, comprised 216 coaches, managers and doctors. Four studies comprised samples that were evenly distributed by gender ( $40-60 \%$ male) $6,21,77,114$, ten were made up primarily of males (> 60\%) 8,11,12, 67, 77, 85, 94,103,121, and one did not report gender, although since the sample was drawn from English professional soccer we anticipate that it was male-only 133.

The majority of subjects were aged $18-30$ years in the eleven studies that provided age statistics $6,8,11,12,21,77,85,94,103,114,121,133$. No study offered information on the respondents ethnicity mix. Two studies assessed track and field athletes only 12, 21, two focused on soccer players ${ }^{8,133}$ and one study each examined endurance walkers ${ }^{67}$ and fencers ${ }^{77}$. The remaining studies $6,11,77,85,88,94,103,114,121$ drew subjects from a range of sports, including cycling, swimming, baseball, rowing, cricket and rugby.

\subsubsection{Methods}

Cross-sectional survey designs were used in all studies. Of the eleven studies that employed self-report questionnaires, 10 were administered face-to-face $6,8,11,12,21,94,114$ and one was distributed by post ${ }^{133}$. Anshel ${ }^{11}$ supplemented questionnaire data with information drawn from personal interviews conducted with all subjects. McArdle 77 and Scarpino et al ${ }^{103}$ conducted face-to-face semi-structured interviews. All researchers devised their own questionnaire for the purpose of the particular study at hand, providing no psychometric detail.

Since no two studies employed the same questionnaire, a coherent synthesis and definitive conclusion pertaining to the attitudes, beliefs and knowledge of elite athletes is not possible. Instead, key themes explored across the body of research will be examined together. Studies sought to understand subjects' attitudes towards drug use $6,8,11,12,21,77,85,94,103,114,121,133$ and/or 
prevention and testing $21,67,77,103,121,133$. Researchers examined personal, team-mates or competitors use of performance enhancing or recreational drugs $6,8,11,88,94,103,133$, over the counter medicines ${ }^{21}$, or anabolic steroids ${ }^{12,85}$. A number of studies examined subjects' knowledge (effects, legality, etc) of doping and/or recreational drugs 12, 67, 77,85, 114. More specifically, McArdle 77 explored the perceptions of elite Fencers on the issue of performance enhancing drug use, with particular reference to how their attitudes were influenced by the experiences of Diane Modahl, a British 800-meter runner who tested positive for testosterone at the European Championships in 1994, but was subsequently exonerated due to testing flaws. Somerville and Lewis ${ }^{114}$ worked to identify the educational needs of elite sportspeople, by examining the frequency with which they received doping education, the format and usefulness of this information and ways in which the system could be improved. Lastly, Chester et al ${ }^{21}$ explored knowledge, attitudes and use of over the counter medications, which have been known to contain banned substances and cited by some athletes as the cause of a positive test result.

A number of National Doping Agency reports were also uncovered through the search, including a report by the US Anti-Doping Agency entitled 'Educational Program Development Athlete Survey' ${ }^{229}$, UK Sport entitled 'Drug Free Sport Survey' 128 and the Netherlands Centre for Doping Affairs entitled 'Three Anti-doping Studies from the NeCeDo: Education, Gaps and Anti-doping in Intellectual Sports' ${ }^{\prime 3}$. While these reports provide worthwhile statistics and perspectives, they have not been included in the main analysis as they did not satisfy our inclusion criteria.

\subsubsection{Findings: Prevalence and reasons for doping}

There was consistent evidence that athletes are engaging in doping behaviours or perceive that team-mates or competitors are doing so, although a reliable estimate of prevalence cannot be provided. Three studies assessed personal use of performance enhancing drugs $8,85,88$, whilst six asked for estimates of use by team-mates or competitors $6,11,67,77,85,103,133$. The proportion of respondents admitting to personal use of banned substances ranged from 1.2\% 85 to $8 \% 8$. Indications of the proportion of other athletes (team-mates or competitors) using performance enhancing drugs, rates of usage, varied widely but were considerably greater than self-reported use. The percentage of respondents indicating that they knew of another athlete using banned substances ranged from 6\% 133 amongst a sample of English soccer players to $72 \%$ among 
female Australian athletes from a variety of sports ${ }^{11}$. Estimates of use amongst team-mates or competitors ranged from $6 \%$ to $34 \% 133$.

Five studies explored why athletes had used, or why they perceived others had used, performance enhancing drugs. Anshel 11 provides a detailed exploration of reasons for use of banned substances in sport, relating that motives fall into three categories; improving physical performance and meeting psychological or social needs. Frequently cited motives fall under five broad umbrella terms, including to win in competition 67, 103, for financial gain (associated with improved performance and success) 67,121 , to improve physical performance $67,88,103$, to solve weight problems ${ }^{88}$, or to reduce pain 103.

\subsubsection{Findings: Knowledge of doping}

Deficits in knowledge were identified across the studies that assessed this issue $67,85,88,114$. Anshel and Russell 12 also assessed subjects doping knowledge, but discussed findings only in relation to how they impacted upon attitude and did not detail actual athlete knowledge. Due to the divergent methods used between studies it is not possible to directly compare findings. However, it appears that athletes commonly lack doping knowledge. For example, Laure and Riensberger 67 found that endurance walkers could only name, on average, 1.5 of the drugs on the International Olympic Committees banned list. In terms of health consequences, Ohaeri et al 85 found that over $80 \%$ of Nigerian athletes were unaware that using anabolic steroids could result in tendon injuries, acne or gynaecomastia. This lack of awareness was also noted by Ozdemir et al. 88 .

A limited number of studies examined elite athletes' knowledge of doping and all studies discussed here made only limited attempts to assess knowledge, largely by subjective, self-report means. Future research must begin to examine actual knowledge rather than perceived knowledge, which is unreliable. Anshel and Russell ${ }^{12}$ attempted to assess subjects knowledge of anabolic steroid using a 40-item questionnaire, but failed to provide detailed statistics of the subjects scores. Interestingly, what was reported was that greater knowledge about steroids and their effects on an athlete's physical and mental health was not significantly related to their attitudes about the use of steroids. 


\subsubsection{Findings: Attitudes towards doping prevention, testing and education}

The vast majority of athletes acknowledged the need for work to be undertaken in doping prevention and, in principal, supported the use of drug testing 77,103,121. For example, a large proportion of subjects requested more frequent and efficacious control over the sports environment 103 and $98 \%$ of athletes surveyed, indicated that measures should be taken to combat doping in sport ${ }^{121}$. McArdle 77 reported that athletes believed that the freedom to use performance enhancing drugs was something to be avoided. Indeed, a considerable proportion of athletes believed that drug testing should be conducted more frequently 103,121. Eighty-two percent of athletes in an Italian survey said they would be in favour of systematic doping checks during training ${ }^{103}$. Similarly, across a range of performance levels (national, international-youth, international, professional), 48 - $75 \%$ of German athletes indicated that testing was not being conducted often enough 121.

Despite the generally positive attitude towards doping prevention, athletes harbour concerns over the integrity and effectiveness of current drug testing methods $67,77,103,121,133$. Concerns over the validity of testing were also expressed. McArdle $77 ;$ p.50) states "The fencers were of the opinion that a rational, coherent and scientifically valid testing policy had yet to be developed, and the system that did exist had been undermined by the perceived corruption of international sport". However, McArdle ${ }^{77}$ drew upon a very small sample $(\mathrm{N}=12)$ and therefore findings cannot be generalised to the wider athletic community. 
Table 3. Descriptive analysis of studies examining the attitudes of elite athletes towards doping in sport.

\begin{tabular}{|c|c|c|c|c|}
\hline $\begin{array}{c}\text { First author } \\
\text { (year) }\end{array}$ & Country & Sample & Methods & Summary \\
\hline $\begin{array}{l}\text { Alaranta et al } \\
(2006)\end{array}$ & Finland & $\begin{array}{l}446 \text { Elite athletes } \\
\text { Mean age }-23.0 \text { years } \\
\text { Response rate }-90 \%\end{array}$ & $\begin{array}{l}\text { Questionnaire (7 items) } \\
\text { [Key themes: athletes beliefs } \\
\text { and attitudes to doping } \\
\text { across different sports] }\end{array}$ & $\begin{array}{l}\text { - Overall } 90 \% \text { of athletes believed that performance could be improved with the } \\
\text { use of banned substances. None of the athletes admitted use. } \\
\text { - } \quad \text { 90\% said it was possible to reach the highest level of achievement without } \\
\text { doping. } \\
\text { - Athletes from skill-based events were most likely to indicate that banned } \\
\text { substances were not effective in enhancing performance. } \\
42 \% \text { of athletes in speed and power sports knew of another athlete using } \\
\text { banned substances, whilst just } 17 \% \text { from skill-based sports shared this view. } \\
\text { - } \quad \text { Across all sports, men were more likely to know of another athlete using doping } \\
\text { agents than women. } \\
\text { - } 7 \% \text { of athletes stated they would start using currently banned substances if they } \\
\text { were allowed, and } 3 \% \text { believed that doping agents could be used completely or } \\
\text { nearly without adverse effects. }\end{array}$ \\
\hline Ama et al. (2003) & Africa & $\begin{array}{l}723 \text { amateur players, } \\
314 \text { professional } \\
\text { footballers and } 79 \\
\text { female footballers } \\
(n=1116)\end{array}$ & $\begin{array}{l}\text { Questionnaire (30 items) } \\
\text { [Key themes: use and } \\
\text { awareness of } \\
\text { social/recreational drugs, } \\
\text { doping substances and } \\
\text { nutritional supplements] }\end{array}$ & $\begin{array}{l}\text { - } 60 \% \text { stating they had not heard of cocaine, } 68 \% \text { were not aware of anabolic } \\
\text { steroids and } 74 \% \text { had not heard of amphetamines. } \\
\text { - } 7 \% \text { of all respondents indicated that they had used cocaine before a match, with } \\
\text { greatest use amongst local players ( } 8 \% \text { ), followed by professional footballers } \\
\text { (5\%) and female players (3\%). } \\
\text { - A small percentage (6\%) of amateur and professional players reported using } \\
\text { liboga (a plant root with stimulating effects) before matches. }\end{array}$ \\
\hline Anshel (1991) & USA & $\begin{array}{l}126 \text { Elite Athletes } \\
\text { Males - 75\% }\end{array}$ & $\begin{array}{l}\text { Interview } \\
\text { [Key themes: performance } \\
\text { enhancing and recreational } \\
\text { drug use by team-mates; } \\
\text { reasons for use; Problem- } \\
\text { Behaviour Theory] }\end{array}$ & $\begin{array}{l}\text { - Reasons for using performance enhancing drugs fell into three categories: (1) } \\
\text { physical, (2) psychological/emotional and (3) social. } \\
\text { - } \quad \text { Physical causes - reduce pain, speed recovery from injury, increase or decrease } \\
\text { energy and arousal (usually dependant on the sport). } \\
\text { - } \quad \text { Psychological and emotional causes - fear of failure and lack of self-confidence. } \\
\text { - Social causes - modelling of significant others or rewarded behaviour and a lack } \\
\text { of social support, especially amongst female athletes. } \\
\text { - Findings are explored using Jessors (1982) Problem Behaviour Theory, wherein } \\
\text { athletes view drug use as desirable, or even necessary, due to situational } \\
\text { demands, implications, expectations, roles or personal needs. }\end{array}$ \\
\hline
\end{tabular}


Table 3. Descriptive analysis of studies examining the attitudes of elite athletes towards doping in sport.

\begin{tabular}{|c|c|c|c|c|}
\hline $\begin{array}{l}\text { First author } \\
\text { (year) }\end{array}$ & Country & Sample & Methods & Summary \\
\hline $\begin{array}{l}\text { Anshel \& Russell } \\
\text { (1997) }\end{array}$ & Australia & $\begin{array}{l}291 \text { elite track and field } \\
\text { athletes } \\
186 \text { males ( } 25.3 y r s) \\
105 \text { females ( } 22.6 \text { yrs) } \\
72 \% \text { response rate }\end{array}$ & $\begin{array}{l}\text { Questionnaire (74 items) } \\
\text { [Key themes: relationship } \\
\text { between knowledge of AS } \\
\text { and attitudes towards AS; } \\
\text { Health Belief Model, Theory } \\
\text { of Reasoned Action] }\end{array}$ & $\begin{array}{l}\text { - Multiple regression analysis indicated relatively low } R^{2} \text { values and correlations } \\
\text { (>0.20) between various components of subjects' knowledge and their attitude } \\
\text { toward steroid ingestion. } \\
\text { - Males had higher mean knowledge scores than females at all levels of education } \\
\text { except college/university. } \\
\text { - Greater knowledge about steroids and their effects on the athletes' physical and } \\
\text { mental health was not significantly related to their attitudes about using steroids } \\
\text { in sport. } \\
\text { - The author comments that existing educational programmes for may have } \\
\text { limited value in terms of creating appropriate attitudes to reduce steroid use. }\end{array}$ \\
\hline $\begin{array}{l}\text { Chester et al } \\
(2003)\end{array}$ & UK & $\begin{array}{l}199 \text { Track \& Field } \\
\text { Athletes and } 202 \text { non- } \\
\text { athletes ( } n=401) \\
\text { Response rate }-73 \%\end{array}$ & $\begin{array}{l}\text { Questionnaire } \\
\text { [Key themes: use of and } \\
\text { attitudes toward over-the- } \\
\text { counter (OTC) medicines] }\end{array}$ & $\begin{array}{l}\text { - } 3.4 \% \text { of athletes stated they had used OTC drugs to enhance performance, but } \\
\text { less than half of those believed they had been effective. } \\
\text { - } 23.5 \% \text { of athletes and } 14.4 \% \text { of non-athletes believed that OTC drugs should be } \\
\text { banned. }\end{array}$ \\
\hline $\begin{array}{l}\text { Curry \& Wagman } \\
\text { (1999) } \\
\text { (detailed analysis } \\
\text { presented in } \\
\text { section } 4.5 \text { - } \\
\text { included here for } \\
\text { completeness) }\end{array}$ & USA & $\begin{array}{l}15 \text { US Powerlifters } \\
\text { Response rate - } 60 \% \\
\text { Age range - } 23 \text { to } 45 \\
\text { years }\end{array}$ & $\begin{array}{l}\text { Questionnaire } \\
\text { [Key themes: use of and } \\
\text { experience with anabolic } \\
\text { steroids; effectiveness of } \\
\text { doping controls; attitudes } \\
\text { regarding competing with or } \\
\text { without doping control] }\end{array}$ & $\begin{array}{l}\text { - } 10 \text { respondents admitted to having used anabolic steroids and } 5 \text { had beaten the } \\
\text { IOC doping control procedures. } \\
\text { - All subjects indicted that they suspected steroid use amongst other Powerlifters } \\
\text { at National and International competitions, accompanied by comments that } \\
\text { subjects 'knew for a fact' this was happening and that it was 'no secret' and they } \\
\text { had 'done it'. } \\
\text { - } 10 \text { respondents stated that steroids could be used in sufficient dosage to } \\
\text { improve performance without hazard to health. } \\
\text { - } 11 \text { subjects reported that they would prefer a situation where no performance } \\
\text { enhancing drugs were allowed and detection was } 100 \% \text { effective. }\end{array}$ \\
\hline
\end{tabular}


Table 3. Descriptive analysis of studies examining the attitudes of elite athletes towards doping in sport.

\begin{tabular}{|c|c|c|c|c|}
\hline $\begin{array}{c}\text { First author } \\
\text { (year) }\end{array}$ & Country & Sample & Methods & Summary \\
\hline $\begin{array}{l}\text { Laure \& } \\
\text { Reinsberger } \\
\text { (1995) }\end{array}$ & France & $\begin{array}{l}102 \text { high-level } \\
\text { endurance walkers } \\
91.5 \% \text { male } \\
\text { Response rate = 54\% }\end{array}$ & $\begin{array}{l}\text { Questionnaire (13 items) } \\
\text { [Key themes: Knowledge } \\
\text { and attitudes of doping; } \\
\text { excusable doping practices; } \\
\text { health risks; prevalence of } \\
\text { use] }\end{array}$ & $\begin{array}{l}\text { - Motives for doping in sport, (1) to increase performance (17\%), wish to win } \\
(15 \%) \text { and for financial reasons (11\%). } \\
\text { - Subjects were unclear as to whether or not existing sanctions for doping were } \\
\text { adequate or acted as a deterrent, but indicated that tests for doping should be } \\
\text { conducted. } \\
\text { - Subjects were familiar with anabolic androgenic steroids and amphetamines as } \\
\text { doping agents but did not show extensive knowledge of other possible } \\
\text { substances. } \\
\text { Doping definition in this sample stems from potential benefits rather than the } \\
\text { potential costs (e.g. substance to enhance physical/mental performance, not } \\
\text { illegal) }\end{array}$ \\
\hline McCardle (1999) & UK & 12 Elite Fencers & $\begin{array}{l}\text { Semi-structured interview } \\
\text { [Key themes: knowledge and } \\
\text { perceptions of drug testing; } \\
\text { effects of drug use; attitudes } \\
\text { towards sources of doping } \\
\text { information; Diane Modahl } \\
\text { case]. }\end{array}$ & $\begin{array}{l}\text { - The majority of subjects had poor knowledge of the effects of anabolic steroids } \\
\text { and other performance enhancing drugs. } \\
\text { Overall, there primary source of information on drugs were newspaper reports } \\
\text { and subjects lacked faith in the official sources of information on doping and } \\
\text { preferred to seek advice from other athletes, doctors or pharmacists if } \\
\text { necessary. } \\
\text { - All participants reported that they did not have confidence in testing procedures, } \\
\text { and without prompting referred to the Diane Modahl case as the main reason for } \\
\text { this. } \\
\text { A number of subjects expressed concerns about testing positive for substances, } \\
\text { such as caffeine or codeine, which can be found in 'over-the-counter' products. } \\
\text { Most participants believed that giving athletes the freedom to take performance } \\
\text { enhancing substances should be resisted. }\end{array}$ \\
\hline $\begin{array}{l}\text { Ohaeri et al } \\
\text { (1993) }\end{array}$ & Nigeria & $\begin{array}{l}250 \text { Professional } \\
\text { Nigerian Athletes } \\
\text { Response rate }-83 \% \\
72.4 \% \text { males } \\
\text { Mean age - } 24.6 \text { years }\end{array}$ & $\begin{array}{l}\text { Questionnaire } \\
\text { [Key themes: use and } \\
\text { awareness of anabolic } \\
\text { steroids and other drugs; } \\
\text { perception of muscle build; } \\
\text { satisfaction with body shape] }\end{array}$ & $\begin{array}{l}\text { - } 1.2 \% \text { reported previous use of AS, } 5.6 \% \text { use of codeine/Feldene/Omega H3. } \\
\text { - } \quad 14.8 \% \text { reported knowing a Nigerian sportsperson using AS } \\
\text { - } \quad \text { Side effects knowledge of AS use was poor. Over } 80 \% \text { of athletes were not } \\
\text { - } \quad 8 \% \text { suggested that team-mates encouranged use of AS } \\
\text { - } \quad 4 \% \text { stated that they admired the achievements of sportspeople who used AS. } \\
\text { - } 5 \text { subjects admitted that they had trafficked drugs previously. } 13 \text { had been } \\
\text { approached to serve as a drug courier. }\end{array}$ \\
\hline
\end{tabular}


Table 3. Descriptive analysis of studies examining the attitudes of elite athletes towards doping in sport.

\begin{tabular}{|c|c|c|c|c|}
\hline $\begin{array}{l}\text { First author } \\
\text { (year) }\end{array}$ & Country & Sample & Methods & Summary \\
\hline $\begin{array}{l}\text { Ozdemir et al } \\
\text { (2005) }\end{array}$ & Turkey & $\begin{array}{l}433 \text { Athletes and } 450 \\
\text { Healthy Non-Athletes } \\
(n=883) \\
\text { Mean age }-21.8+/-3.7 \\
\text { yrs } \\
\text { Males - } 78.2 \%\end{array}$ & $\begin{array}{l}\text { Questionnaire (24 items) } \\
\text { [Key themes: prevalence of } \\
\text { performance enhancing drug } \\
\text { use in athletes; reasons for } \\
\text { use; opinions about doping] }\end{array}$ & $\begin{array}{l}\text { - } 8.0 \% \text { (71 cases in } 883 \text { subjects) reported doping. } \\
\text { - } \quad \text { Doping drug use among the athletes was significantly }(\mathrm{P}<0.05) \text { higher }(14.5 \%) \\
\text { compared with the non-athletes }(1.8 \%) \text {. } \\
\text { - } \quad \text { Prevalence rates in men were significantly higher }(\mathrm{P}<0.05) \text { than women. } \\
\text { - } \quad \text { Usage rates were reported with AS use being the greatest }(60.5 \%) \text {. } \\
\text { (gaining or loosing) problems. } 11.3 \% \text { doped due to pressure from others }(41.3 \% \\
\text { reported that friends advised them). } \\
\text { - } 52 \% \text { were unaware of the potential side effects of doping. } \\
\text { - } 32 \% \text { of athletes who dope agreed that the legalisation of doping was acceptable } \\
\text { compared with } 9.8 \% \text { who do not dope. }\end{array}$ \\
\hline $\begin{array}{l}\text { Peretti-Watel et al } \\
(2004)\end{array}$ & France & $\begin{array}{l}458 \text { Elite student } \\
\text { athletes } \\
\text { Response rate - } 74 \%\end{array}$ & $\begin{array}{l}\text { Questionnaire (127 items) } \\
\text { [Key themes: attitudes } \\
\text { towards doping, their } \\
\text { correlates and their } \\
\text { relationship with cigarette, } \\
\text { alcohol and cannabis use; } \\
\text { sociology of deviance } \\
\text { perspective; 'neutralisation', } \\
\text { 'positive deviance' and self- } \\
\text { fulfilment] }\end{array}$ & $\begin{array}{l}\text { - Over } 90 \% \text { of all athletes reported that doping was dishonest, unhealthy and/or } \\
\text { hazardous because of sanctions. } \\
\text { - Three clusters of subjects were identified: those that considered doping as (1) } \\
\text { both dangerous and useless, (2) dangerous but efficient in improving } \\
\text { performance and (3) dangerous but necessary adjunct to sporting and non- } \\
\text { sporting achievement. } \\
\text { - Other factors associated with a positive attitude towards doping were lower } \\
\text { personal and parental academic achievement and greater involvement in } \\
\text { sporting practice (assessed by number of hours per week spent in sporting } \\
\text { activity). }\end{array}$ \\
\hline $\begin{array}{l}\text { Scarpino et al } \\
\text { (1990) }\end{array}$ & & $\begin{array}{l}1015 \text { Italian athletes } \\
\text { and } 216 \text { coaches, } \\
\text { doctors and managers } \\
(n=1231) \\
\text { Males - } 67 \% \\
\text { Italy }\end{array}$ & $\begin{array}{l}\text { Semi-structured Interviews } \\
\text { [Key themes: Knowledge of, } \\
\text { attitudes to and use of illegal } \\
\text { drugs and other forms of } \\
\text { doping] }\end{array}$ & $\begin{array}{l}\text { - }>10 \% \text { of athletes stated that amphetamines and AS were being used frequently } \\
\text { at national or international level. } \\
\text { - Overall, } 30 \% \text { of athletes, coaches and managers thought athletic performance } \\
\text { could be enhanced by doping. } \\
\text { - Athletes' most frequently cited reasons for using doping agents were to win in } \\
\text { competition (63\%), improve training performance }(9 \%) \text {, reduce pain (6\%) and at } \\
\text { the request of a coach (6\%). } \\
\text { - The majority of athletes believed that they had been put under external pressure } \\
\text { to use drugs or doping practices. } \\
\text { Three-quarters of athletes indicated that access to illegal substances was not } \\
\text { difficult. A greater number of subjects indicated that doping was potentially } \\
\text { harmful than stated it was efficacious in improving performance. }\end{array}$ \\
\hline
\end{tabular}


Table 3. Descriptive analysis of studies examining the attitudes of elite athletes towards doping in sport.

\begin{tabular}{|c|c|c|c|c|}
\hline $\begin{array}{l}\text { First author } \\
\text { (year) }\end{array}$ & Country & Sample & Methods & Summary \\
\hline $\begin{array}{l}\text { Somerville \& } \\
\text { Lewis (2005) }\end{array}$ & UK & $\begin{array}{l}74 \text { Athletes } \\
\text { (athletics, cycling, } \\
\text { rowing and sailing } \\
\text { Response rate }-38 \%\end{array}$ & $\begin{array}{l}\text { Questionnaire } \\
\text { [Key themes: opinions } \\
\text { regarding accidental } \\
\text { breaches of doping } \\
\text { regulations; educational } \\
\text { needs; effective practice] }\end{array}$ & $\begin{array}{l}\text { - } 92 \% \text { had received a doping education update within the last } 6 \text { months and most } \\
\text { believed it was relevant. } \\
\text { - } \quad \text { Participants would prefer to receive more regular reminders about doping issues. } \\
\text { Most frequently suggested methods of improving athletes knowledge was to (a) } \\
\text { increase awareness of the UK Sport website and (b) provide regular updated } \\
\text { lists of acceptable medicines and supplements. } \\
\text { - Inadequate labelling or changes in product composition and human error were } \\
\text { reasons for accidental breaches. }\end{array}$ \\
\hline $\begin{array}{l}\text { Striegel et al } \\
(2002)\end{array}$ & Germany & $\begin{array}{l}101 \text { National and } \\
\text { International German } \\
\text { Athletes } \\
64 \% \text { males }\end{array}$ & $\begin{array}{l}\text { Questionnaire } \\
\text { [Key themes: psychosocial } \\
\text { motivates for drug taking; }\end{array}$ & $\begin{array}{l}\text { - } 98 \% \text { believed measures should be taken to combat doping in sport. } \\
\text { - } \quad \text { Improved methods of detection and more information on the health risks of } \\
\text { doping were preferable to more severe punishments for drug users. } \\
\text { - } \quad 21 \% \text { believed the current dope testing to be sufficient. } \\
\text { - } 74 \% \text { of athletes supported Government intervention in anti-doping efforts } \\
\text { - } \quad \text { Reasough the establishment of an anti-doping law. } \\
\end{array}$ \\
\hline $\begin{array}{l}\text { Waddington et al } \\
\text { (2005) }\end{array}$ & UK & $\begin{array}{l}706 \text { Professional } \\
\text { footballers } \\
\text { Response rate }-25 \%\end{array}$ & $\begin{array}{l}\text { Questionnaire } \\
\text { [Key themes: knowledge of } \\
\text { PED use; attitudes towards } \\
\text { drug testing; peer use; } \\
\text { nutritional supplements] }\end{array}$ & $\begin{array}{l}\text { - } 34 \% \text { believed performance enhancing drugs were being used by some players } \\
\text { and } 6 \% \text { stated that they knew someone personally that was using them. } \\
65 \% \text { of players reported that they had been tested for banned drugs within the } \\
\text { last two years, 35\% reported that they had not been tested and } 60 \% \text { believed it } \\
\text { was unlikely that they would be tested within the next twelve months. } \\
\text { - } 73 \% \text { reported a positive attitude towards drug testing as a deterrent. } \\
\text { - } 59 \% \text { believed that punishment for drug use was 'about right' whilst } 25 \% \text { felt that } \\
\text { it was 'not severe enough' }\end{array}$ \\
\hline $\begin{array}{l}\text { Wagman et al } \\
\text { (1995) } \\
\text { (detailed analysis } \\
\text { presented in } \\
\text { section } 4.5- \\
\text { included here for } \\
\text { completeness) }\end{array}$ & US & $\begin{array}{l}15 \text { Elite Powerlifters } \\
10 \text { former or current } \\
\text { 'users' and } 5 \text { 'non-users' } \\
\text { Response rate }=60 \%\end{array}$ & $\begin{array}{l}\text { King Drugs in Sport } \\
\text { Questionnaire (1991) } \\
\text { [Key themes: AAS use; } \\
\text { attitudes towards AAS use \& } \\
\text { current technology; } \\
\text { conformation] }\end{array}$ & $\begin{array}{l}\text { - All participants believed their competitors were using AAS. } \\
\text { - } 2 / 3 \text { of all respondents believed current doping controls were ineffective. } \\
\text { - Users were more likely than non-users to believe that 'I would not be hurting } \\
\text { anyone else if I decided to use AS' and that 'Taking AS is necessary if I am to be } \\
\text { competitive in my sport'. } \\
\text { - Non-users were more likely to agree that 'I do not need AS to help me become the } \\
\text { best athlete I can be'. } \\
\text { - All non-users compared to } 60 \% \text { of users indicated that they would not want to } \\
\text { compete if there were no doping controls. }\end{array}$ \\
\hline
\end{tabular}




\subsubsection{Discussion}

Despite a reliance on self-report measures, there is consistent evidence to support the contention that elite athletes are engaging in doping practices. However, a reliable estimate of prevalence has yet to be established. Existing research suggests that a considerable proportion of athletes lack doping knowledge, in terms of effects, legal issues or sources of information. This may increase their risk for damaging their health or inadvertently committing a doping offence. Whilst most athletes report negative attitudes towards doping in sport and are in favour of taking steps to prevent the use of performance enhancing drugs, they remain concerned about the value of testing as a deterrent and question the reliability and integrity of testing procedures. Although systematic and evidence based research is scarce in this respect, athletes appear to be in favour of increased drug testing, and would like more information to be provided by National Governing Bodies and anti-doping agencies.

A number of studies have sought to establish the motives for using doping agents and across this small body of published literature, the findings are somewhat consistent. Elite athletes' motives for doping are primarily concerned with maintaining or improving physical functioning, coping with social or psychological pressures or striving for social or psychological goals. Investigations of drug use amongst elite athletes should acknowledge that they are subject to unique social and psychological conditions, which distinguish them from other groups of athletes (intense pressure from sponsors, media, spectators; opportunities for huge financial reward); these combinations may increase the likelihood of doping. Accordingly, it is advisable that doping education and prevention initiatives should be tailored to the unique experience of being an elite athlete to ensure that athletes are properly equipped to deal with the pressures of high profile sport. With regards to athletes' knowledge of doping, few empirical investigations have examined this research question and therefore conclusions cannot be drawn. In the studies identified here, athletes' are deficient in knowledge regarding prohibited substances and/or their effects, legal issues and understanding of the testing process. Given the likelihood of considerable knowledge variation between different nations, sports and indeed between teams and individuals, this warrants further research into such contextual factors. 
Based on this small number of studies, one could conclude that WADA and NADO's are faced with a considerable challenge; guaranteeing the reliability and integrity of drug testing procedures and regaining the confidence of those athletes subjected to testing. So long as testing fails to be $100 \%$ effective in identifying drug users then this deficiency may be exploited, such are the rewards for sporting success. Cases in which athletes have been identified as providing a positive sample, only for flaws in procedure or testing to be identified at a later date, evoke mistrust and apprehension amongst athletes subjected to testing. This is a complex issue, and it is unclear at this stage exactly what action should be taken to resolve it. A key step in the process is likely to involve gathering more data, outlining in greater detail elite athletes attitudes and experiences with drug testing, aligned to continued research. 


\section{$4 \quad$ ATTITUDES TOWARDS DOPING}

\subsection{Detailed Analysis - College Athletes}

\subsubsection{Summary}

Elite athletes represent a relatively small group who are potentially at risk for using performance enhancing drugs. There is also a concern that doping may be increasing among amateur athletes and the physically active young ${ }^{92}$. College level athletes often approach their sport with high commitment and in the US in particular the stakes are high. Consequently, repeated efforts have been made to document the extent of the doping problem. However, the findings are clouded by heterogeneous research methodologies which limit the ability to synthesise the available evidence to arrive at firm conclusions. Still, the information that follows is a detailed analysis of the main findings of peer-reviewed published articles that have gone beyond merely reporting prevalence statistics by offering information on college athletes' attitudes and knowledge of doping and drug testing systems.

\subsubsection{Background}

Eighteen articles were identified that explored doping behaviours amongst college or university athletes, sixteen from the United States 7, 9, 15, 22-24, 28, 45, 54, 60, 90, 96, 104, 127, 139 and one each from Canada 115 and Australia ${ }^{89}$. A brief descriptive analysis of each study can be found in Table 4 and study annotations are located in Appendix A.

\subsubsection{Sample}

Total sample across all studies was 12 043, with a mean of 669 participants per study. Sample size varied considerably, from just eight subjects recruited for a qualitative investigation of male athletes attitudes towards drug use and testing 28 to 2282 for a national survey of drug and alcohol behaviour in college athletes 7,9 . In terms of gender composition, samples from three studies were evenly distributed by gender (40 - 60\% male) $22,54,89$ and eleven samples were predominantly male (>60\%) 9, 15, 23, 24, 28, 45, 54,60,96, 104, 115, 139. Three studies failed to report gender or the actual percentage composition of the sample 7,90,127. Samples comprised subjects from all college years, with mean age falling between 19 - 24 years 15, 22, 28, 54, 60, 89, 104. Eleven studies 
did not indicate subjects' age 7, 9, 23, 24, 45, 54, 90, 96, 115, 127, 139 and only five studies reported subjects' ethnicity. Of these, four were predominantly 'white' or Caucasian 7, 9, 28, 60 and one primarily African-American ${ }^{96}$. In all cases, subjects were drawn from a range of sports, though given the gender bias in sampling it is likely that participants from female dominated sports may be underrepresented.

\subsubsection{Methods}

All papers report using a cross-sectional survey method. Twelve studies employed only a questionnaire to gather data 7, 9, 15,22, 28, 45, 54,60,89, 127, 139, two conducted in-depth interviews 28,96 and three combined questionnaire and interview methods $23,24,54$. Twelve studies developed a questionnaire specific to the research at hand $15,23,24,45,54,56,60,89,90,139$, three studies employed modified versions of a questionnaire devised in previous research 7,9,115, and one study used the King Drugs in Sport Questionnaire (KDSQ) ${ }^{127}$. The KDSQ, devised and validated by King ${ }^{61}$, assesses subjects' knowledge about anabolic steroids, side-effects, where to get these drugs and information about personal steroid use. Alongside establishing prevalence rates of doping use eight studies examined subjects' knowledge or attitudes towards college drug testing 7, 23, 24, 28, 45, $54,56,60$, four considered attitudes towards anabolic steroid use and steroid users 22, 60, 89, 139, one dealt with stimulant misuse ${ }^{15}$ and five examined attitudes towards drug or alcohol use more generally $9,90,96,115,127$.

\subsubsection{Findings: Framing the issue - the prevalence of drug use}

There was consistent evidence that college/university athletes are violating doping regulations or perceive their team-mates and fellow competitors to be doing so. Prevalence rates (indicated by self-report) vary and reliable estimates have not been provided to date. Surveying drug use comes in many forms. Some studies choose to focus entirely on the use of particularly substances such as anabolic steroids (AS) $22,60,139$ or stimulants ${ }^{15}$. Other studies focus on drug use in general (including social substances such as alcohol) and often times estimates of AS use are presented 9,115 . Such heterogeneous methodologies may explain the diverse usage rates reported in the literature. In the studies that have used a self-report methodology to assess AS use, the proportion of respondents admitting to personal use ranged from $3.2 \% 115$ to $23 \% 22$. However, the high prevalence rate reported by Chng and Moore must be interpreted with caution 
because the sample included community gym members, targeted due to anecdotal evidence that this group of gym members included a significant proportion of AS users. Consequently, the extrapolation of this estimate to college athletes may not be appropriate.

It is beyond the scope of this review to fully examine the prevalence research. However, the prevalence rate differences reported across the field could be due, in part, to the variety of questionnaires employed to gather data. Moreover, self-report bias is inherent in this type of methodology and may elicit under-reporting of drug misuse. Response rates varied across the studies and drug users may actively avoid contributing to such research. One study ${ }^{139}$ attempted to overcome this issue by assessing projected use by asking competitors to estimate their fellow competitors' AS use. The overall projected rates were $14.7 \%$ for males and $5.9 \%$ for females. However, the sport engaged in by the competitors had a major influence on these projections. For example, American Football had the highest projected AS use at $29.3 \%$, followed by Track and Field (20.5\%) and Basketball (8.3\%). For males, this projected rate is three times greater than the self-report figures provided by Anderson et al ${ }^{9}$ and Spence and Gauvin ${ }^{115}$. However, projected response techniques generally yield overestimates. Yesalis and colleagues ${ }^{139}$ state that "significantly more work is required to develop and refine methodologies to help penetrate the 'veil of secrecy' surrounding drug use in sport" (p.170).

\subsubsection{Findings: Attitudes towards doping}

Despite the lack of theoretically driven research, studies to-date purport that anti-drug attitudes pervade the college-athlete literature ${ }^{28}$. Generally, athletes perceive drug use to be an unacceptable practice $27,45,54,56,104,127$ and this conclusion stems largely from research conducted in the US through the administration of self-report questionnaires to student-athletes at NCAA Divisional Institutions. For example, ensuring fair competition 28,45 , wanting to win drugfree 22 and the belief that it is unethical to participate in sports when using performance enhancing drugs ${ }^{54}$ were some of the reasons given by college athletes for rejecting the use of performance enhancing substances.

Although this anti-drug attitude is reported, research findings do conflict. For example, Tricker and Connolly 127 noted that athletes identified as 'at risk' would use banned substances given the right 
circumstances, suggesting a measure or moral relativism. Among potential AS users, $12 \%$ of the college athletes agreed that they would use AS if this act of deviance would guarantee that they would reach their athletic potential. For example, an attitude variable that explained $60 \%$ of the variance of intention to use AS was "I would take steroids if I knew that I would not test positive for using them". Moreover, males were much more likely to agree with this statement compared to females. Corroborating this statement are the reports that $34 \%$ of all male hockey players 15 would take a banned substance if it would help them play in the National Hockey League, while $61 \%$ of athletes and $77 \%$ of non-athletes agreed with the statement that 'more college athletes would use drugs if they were not afraid of losing their eligibility' ${ }^{54}$. As concluded by Tricker and Connolly ${ }^{127}$, the research literature suggests that some college athletes are using performance enhancing drugs and more would do so if they perceived that there was little or no chance of detection. Indeed, it was interesting to note the findings of Coombs and Ryan ${ }^{24}$ who found that college athletes reported the loss of social status following a positive drugs test was more of a concern to them than the physical and psychological side effects associated with drug use. Such findings, if replicated across different population types, could offer significant insights into the planning and delivery of effective educational programmes that have historically focused on inculcating knowledge on the negative health side effects of drug misuse. Indeed, Pan and Baker 90 found that male college athletes' were still vulnerable to AS use despite being aware of the dysfunctional side effects of use and surmise that the knowledge approach alone may not effectively deter drug use in college athletes.

Although a number of studies have provided detail on drug use prevalence and types of drugs used, few published empirical studies have thoroughly considered 'why' athletes engage in doping behaviours. Even allowing for inherent self-report bias, such information is potentially valuable since it highlights our limited understanding of the decision making process involved in drug use behaviour; this is further exaggerated by the limited application of theoretical perspectives. Rather uniquely, Tricker \& Connolly ${ }^{127}$ and Peters ${ }^{96}$ used the tenets of the social cognitive theories of Planned Behaviour and Reasoned Action 2, 4 (Figure 1) as a guiding framework for their research, to consider the relationships between attitudes, intentions and behaviour. Using multiple regression analysis, Tricker and Connolly ${ }^{127}$ concluded that the college athletes 'would use banned substances given the 'right' circumstances and that the three 
components of the Theory of Reasoned Action could be used to classify the major deterrents for preventing drug use. Unfortunately, due to the research design, the tenets of the model were not fully analysed and firm conclusions of the applicability of the model in the doping domain cannot be offered at the present time. Further research is therefore warranted to explore the fit of socialcognitive models to this domain.

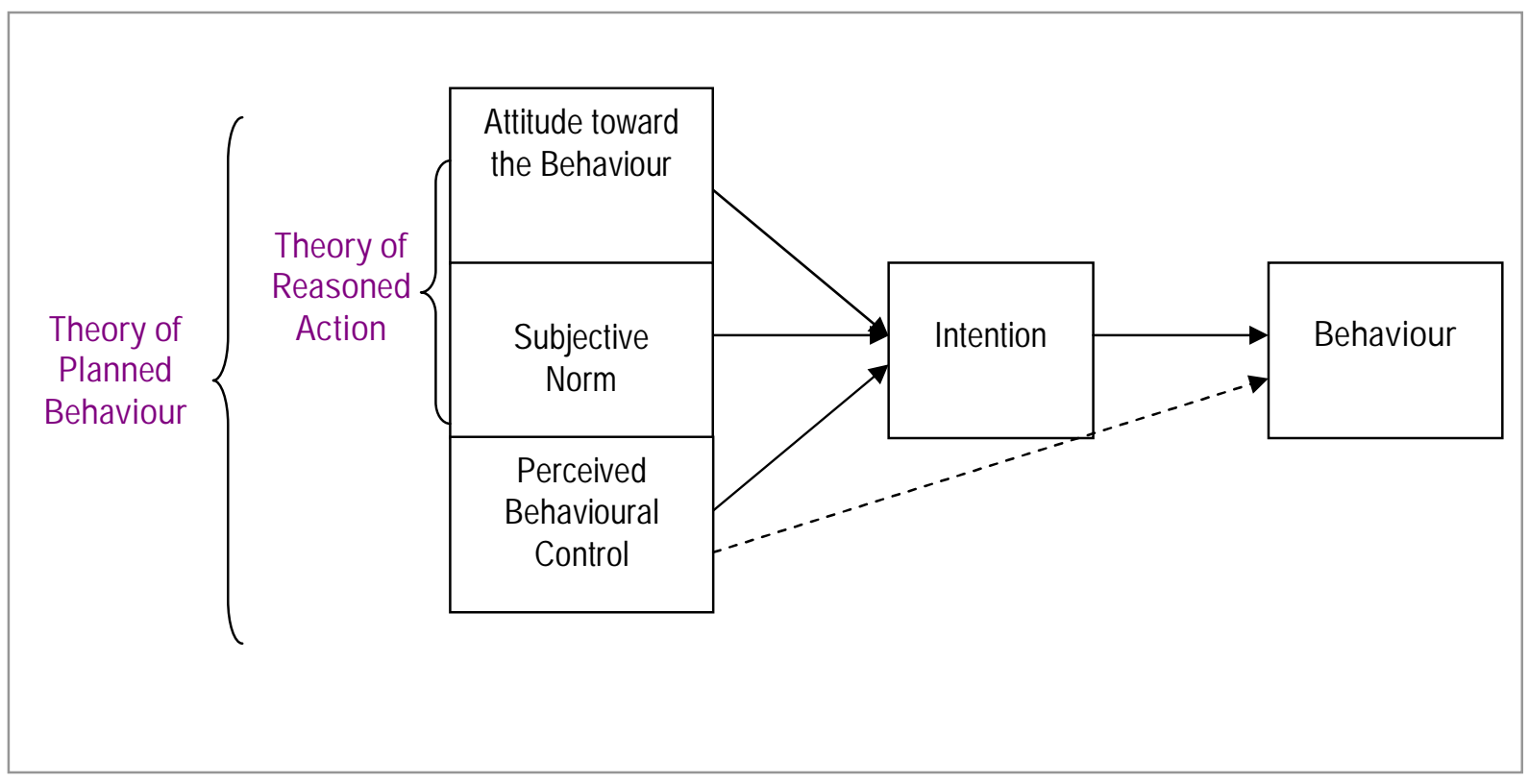

Figure 1. Theories of Reasoned Action ${ }^{2}$ and Planned Behaviour 5

Still, methodological limitations aside, the potential impact of athlete's subjective estimate of the extent that important others want them to participate in a doping behaviour (subjective norm) was emphasised in Tricker and Connolly's ${ }^{127}$ study. For example, the statement "I would take HGH if my team mates wanted me to" exhibited the largest correlation with the statement "I would use HGH if I knew it would make me a better athlete". Further, among college athletes at risk for amphetamine use, their perception that fellow competitors were using such substances predicted $42 \%$ of the variance of their intention to use amphetamines if they knew that they would not get caught. Such findings appear to indicate that athletes' beliefs about their social world and the pressures to perform a target behaviour (and according to the theory, their motivation to comply with such norms) may be useful predictors of doping behaviours. Further, Coombs and Ryan 24 reported that the physiological and psychological side effects associated with drug use, which are 
internal factors, were less of a concern to athletes than loss of social status associated with a positive drugs test (external, or subjective norm factors). Also, in a qualitative study by Peters et al. ${ }^{96}$ male ephedra users reported that their secondary motive for engaging in this behaviour was encouragement from previous high school coaches and friends. Moreover, female ephedra users also reported that they believed it to be the norm among athletes in their college.

Social psychological approaches suggest that an individual's attitude, subjective norms and the degree to which they perceive control over behaviour are important factors that can be used to predict social behaviour ${ }^{5}$. However, perhaps as a function of the methodologies employed, not all studies have identified external factors or subjective norms as motives for drug use. In a study conducted by Chng and Moore 22, the majority of student athletes chose not to engage in anabolic steroid use because of an intrinsic desire to remain healthy, while the main reason for opting to use anabolic steroids was to get stronger (46\% of respondents) and over $30 \%$ reported that they would use anabolic steroids if they felt this would improve their chance of becoming a professional athlete, help them look more muscular, earn more money and enhance their attractiveness to their sex partners. The majority of studies reported in the literature fail to detail the nature of the questionnaire and the items offered, therefore, college athletes may not have been asked to consider the potential impact of such norms. In sum, extensive and systematic testing of the attitude-behaviour models in this domain is lacking. However, early findings suggest that there is potential in the application of social cognitive models.

\subsubsection{Findings: Attitudes toward mandatory drug testing}

The NCAA testing programme featured strongly in the analysis of athletes' attitudes towards drug testing programmes. In sum, the majority of college athletes supported the use of drug testing by Institutions and the NCAA 9, 45 and they were generally positive about drug testing. In the US national survey of alcohol and drug in college athletes ${ }^{9} 65 \%$ of athletes surveyed agreed or strongly agreed that all college athletes should be tested for drug use by their institution or the NCAA. In the Canadian national survey ${ }^{115}$, this figure was higher - $83 \%$ of respondents indicated that they agreed or strongly agreed that Canadian university athletes should be randomly tested. Direct comparisons can be made between college athletes in the US and Canada because the Canadian survey was a modified version of the questionnaire used in the US national survey ${ }^{9}$. 
Unfortunately, these studies are notable exceptions and a preclusion of direct cultural comparisons remains due to the heterogeneous methodologies employed.

Strong support for drug testing was also noted in a single institution survey, thus corroborating the large scale national surveys. In this instance, the majority (90\%) of those surveyed (athletes and non-athletes) felt that the University in question was right to require drug testing of intercollegiate athletes ${ }^{54}$. Moreover, in the same study, $89 \%$ agreed that a professional athlete has the duty not to take illegal drugs and amateur athletes were also expected to abstain from illegal drug use. Gray and Schoof 45 reported that both athletes and non-athletes strongly agreed that drug testing was a good idea because it prevents an unfair advantage. Further support for drug testing came from a study examining the effects of mandatory drug testing on the morale and well-being in college athletes ${ }^{23}$. Of those surveyed, $71 \%$ reported that drug testing was 'no big deal' and over a third stated that it had little impact on their personal lives and was actually interesting. However, despite such positive attitudes towards testing, a number of adverse consequences were also reported. For example, over a third reported that it was a stressful/anxious experience, it was embarrassing and that drug testing had adversely affected the participants' morale. Drawing from the same sample, Issari and Coombs 56 identified gender differences in attitudes towards drug testing, with significantly fewer females reporting that drug testing was an invasion of privacy, a violation of civil rights or unethical compared to males. Furthermore, females were significantly more likely to support mandatory drug testing for all intercollegiate and professional athletes.

Coombs and Coombs ${ }^{23}$ also noted that nearly half of their respondents worried about being incorrectly identified and the authors offer some interesting insights into the educational process of college athletes in regards to mandatory drug testing. A majority of respondents wanted improved educational sessions based on fewer scare tactics. Indeed, the orientation phase in college athlete education appears to be pivotal and the authors assert that the underlying assumption of a drug testing education programme must be that the programme helps rather than ruins the participants. As an aside, this study reported that more than half of the respondents credited the drug-testing policy as a means of providing them with a socially acceptable way of refusing drugs and this finding is certainly worthy of future follow-up. 


\subsubsection{Findings: Attitudes towards the efficacy of the drug testing system}

A number of studies examined the perceived effectiveness of the drug testing programmes in identifying and preventing drug use. Attitudes about the efficacy of mandatory testing programmes and drug education were mixed. Once again, the research stems largely from North America. Firstly, $58 \%$ of college athletes in the US ${ }^{9}$ and $67 \%$ of those in Canada ${ }^{115}$, agreed or strongly agreed that drug testing by their athletic associations has deterred drug use by college athletes. Smaller scale studies corroborated this finding with the percentage of respondents agreeing that drug testing discourages the use of drugs ranging from $56 \%$ to $68 \% 24,104$. These statistics suggest that more than one third of respondents perceive the drug testing programmes to be ineffective and those individuals could be at a greater risk of committing a doping offence. For example, Coombs and Coombs ${ }^{23}$ offered a novel contribution to the literature by supplementing the traditional quantitative questionnaire approach with qualitative interviews to gather richer data. One athlete concluded that "With all your clothes stripped off and two guys watching you from five feet away, it's next to impossible to cheat" (p.175). However, this contrasts with figures for cheating; between $19 \%$ and $31 \%$ of the college athletes subject to testing, strongly agreed or agreed that they were aware of ways to beat the system such as timing their drug use. Indeed, $60 \%$ of tested athletes agreed that sampling needs to be less predictable and that a move to randomised spot checks was required ${ }^{24}$. The rich data supplied offered interesting insight into the attitudes of one athlete who explained "As it is now, drug testing is a joke. At the start of the season you know it's coming, so you can stay clean and pass the initial test. Every athlete I know has a way of finding out when the next test is coming up" (p.989). Therefore, such conflicting reports suggest that statistics alone do not allow conclusions to be made regarding the attitudes of college athletes in relation to the efficacy of the current mandatory drug testing procedures and further qualitative research is required.

On the whole, the literature that met our inclusion criteria suggests that athletes support mandatory drug testing and accompanying education programmes. However, studies suggest that knowledge of procedures is limited at times and this lack of awareness needs to be addressed. For example, in a study by Albrecht and colleagues ${ }^{7}$, more than $70 \%$ of 1,482 athletes attending testing institutions were unable to correctly identify their school's drug testing protocol. In a single-site study, $57 \%$ of those surveyed were not aware of the drugs being tested 
for at their institution ${ }^{104}$. In the Canadian national survey 115 over one third of the participants were unaware of drug education programmes for athletes in their colleges. Other studies have supported the need for improved educational sessions 9, 23,115. 
Table 4.Descriptive analysis of studies examining knowledge, attitudes and beliefs of college athletes on doping in sport.

\begin{tabular}{|c|c|c|c|c|}
\hline First author (year) & Country & Sample & Methods & Summary \\
\hline $\begin{array}{l}\text { Albrecht et al. } \\
\text { (1992) }\end{array}$ & US & $\begin{array}{l}2282 \text { College Athletes } \\
\text { Demographics not } \\
\text { presented }\end{array}$ & $\begin{array}{l}\text { Questionnaire (75-items) \& } \\
\text { Sub-Sample Interview } \\
\text { Follow-Up ( } n=57) \\
\text { [Key Themes: Institution } \\
\text { drug-testing awareness] }\end{array}$ & $\begin{array}{l}\text { - College athletes reported misconceptions regarding drug-testing policies at their } \\
\text { institutions. } \\
\text { - } 36 \% \text { of athletes enrolled at institutions where drug testing programmes were in } \\
\text { effect indicated they were ignorant of testing taking place (21\%) or incorrectly } \\
\text { stated that testing did not occur (15\%). } \\
\text { - Approximately } 70 \% \text { were unable to correctly identify the testing protocol used at } \\
\text { their institution.. }\end{array}$ \\
\hline $\begin{array}{l}\text { Anderson et al. } \\
\text { (1991) } \\
\text { (Replication of } 1985 \\
\text { National survey - } \\
\text { Prevalence and } \\
\text { attitudes about drug } \\
\text { testing) }\end{array}$ & US & $\begin{array}{l}2282 \text { College Athletes } \\
70 \% \text { responses rate } \\
68 \% \text { male, } 32 \% \text { female } \\
11 \text { NCAA-affiliated } \\
\text { colleges \& universities }\end{array}$ & $\begin{array}{l}\text { Questionnaire (over } 300 \\
\text { items) } \\
\text { [Key themes: Personal drug } \\
\text { use behaviours; Changing } \\
\text { prevalence since } 1985 \\
\text { survey; attitudes to drug } \\
\text { testing and drug education; } \\
\text { demographic characteristics] }\end{array}$ & $\begin{array}{l}\text { - Alcohol was the most common drug used by athletes in the last } 12 \text { months. } \\
\text { - Compared to the } 1985 \text { survey there was a } 5 \% \text { decrease in the use of } \\
\text { amphetamines (3\% total use in 1989) and a 6\% increase in the use of major } \\
\text { pain medications ( } 35 \% \text { use in 1989). Overall rate of AS use was } 5 \% \text {. } \\
\text { - } 65 \% \text { of athletes agreed or strongly agreed that all college athletes should be } \\
\text { tested for drug use by their institution or NCAA. } \\
\text { - } 56 \% \text { of athletes agreed or strongly agreed that drug testing by their institution } \\
\text { had deterred drug use. This percentage increased to } 58 \% \text { when drug tested was } \\
\text { conducted by NCAA }\end{array}$ \\
\hline Bents et al. (2004) & US & $\begin{array}{l}122 \text { College Athletes } \\
\text { Mean age }=21.9 \text { years }\end{array}$ & $\begin{array}{l}\text { Questionnaire (23 items) } \\
\text { [Key themes: Prevalence; } \\
\text { student knowledge regarding } \\
\text { ephedrine and other } \\
\text { metabolic stimulants; hockey } \\
\text { players] }\end{array}$ & $\begin{array}{l}\text { - } 58 \% \text { of the collegiate hockey players admitted to using ephedrine, } \\
\text { pseudoephedrine, or amphetamines to enhance performance at some point. } \\
\text { - } 35 \% \text { of the athletes admitted to currently using one or more of the stimulants } \\
\text { surveyed (within the past } 30 \text { days). } \\
\text { - } 34 \% \text { of all players stated that they would take a banned substance if it would } \\
\text { help them play in the NHL. } \\
\text { - Almost } 19 \% \text { of non-stimulant users stated they intended to use NCAA-banned } \\
\text { substances at some point in their college careers } \\
\text { - Nearly } 91 \% \text { of respondents demonstrated awareness and agreement of the } \\
\text { potential health risks associated with taking stimulants. }\end{array}$ \\
\hline
\end{tabular}


Table 4.Descriptive analysis of studies examining the attitudes of college athletes towards doping in sport.

\begin{tabular}{|c|c|c|c|c|}
\hline First author (year) & Country & Sample & Methods & Summary \\
\hline $\begin{array}{l}\text { Chng \& Moore } \\
\text { (1990) }\end{array}$ & US & $\begin{array}{l}222 \text { Mixed Sample } \\
\text { (University \& Community } \\
\text { Gym Athletes \& Non- } \\
\text { Athletes) } \\
\text { Median age = } 24 \text { years }\end{array}$ & $\begin{array}{l}\text { Questionnaire (32-items) } \\
\text { [Key themes: prevalence of } \\
\text { AS use; relationship } \\
\text { between knowledge, } \\
\text { attitudes and prevalence of } \\
\text { AS use] }\end{array}$ & $\begin{array}{l}\text { - Overall AS prevalence use - } 23 \% \text { (Athletes - } 32.5 \% \text {, non-athletes- } 1.5 \%) \\
\text { - Users were more positive and knowledgeable about AS use. } \\
\text { - A moderate, significant correlation ( } r=.48, p<.001 \text { ) was found between attitude and } \\
\text { knowledge. } \\
\text { - Males knew more and had a more positive attitude about AS than females. } \\
\text { - Reasons for AS use (>36\%); (1) Strength gains; (2) Improved chance of becoming } \\
\text { a professional athlete; (3) Look more muscular; (4) Help earn more money; (5) Sex } \\
\text { partners find user more attractive } \\
\text { - Reasons for rejecting use (>30\%): (1) Potentially harmful (2) too many unpleasant } \\
\text { side effects; (3) illegal; (4); want to win drug-free }\end{array}$ \\
\hline $\begin{array}{l}\text { Coombs \& Coombs } \\
1991\end{array}$ & US & $\begin{array}{l}500 \text { Intercollegiate } \\
\text { Athletes } \\
71 \% \text { male }\end{array}$ & $\begin{array}{l}\text { Questionnaire (75-items) \& } \\
\text { Sub-Sample Follow-up } \\
\text { Interview ( } n=57) \\
\text { [Key themes: drug use; } \\
\text { attitudes towards drug } \\
\text { education and testing } \\
\text { programmes; impact of } \\
\text { testing upon drug use } \\
\text { behaviour; morale and well- } \\
\text { being] }\end{array}$ & $\begin{array}{l}\text { - } 71 \% \text { reported that taking part in the drug test was 'no big deal', whilst } 37 \% \text { stated it } \\
\text { was 'interesting' and ' } 36 \% \text { that it was 'educational'. } \\
\text { - Qualitative comments support the above statements - "it was } 15 \text { minutes out of my } \\
\text { - } 47 \% \text { rear" and 'Its an interesting conversation piece". } \\
26 \% \text { that it was 'upsetting'. } \\
\text { - } 38 \% \text { believed drug testing adversely affected athletes' morale. } \\
\text { - } 70 \% \text { believed there was a need for improved educational sessions. } \\
\text { - } 53 \% \text { wanted information on the effects of doping agents. } \\
\text { - Qualitative interviews explored further the need for more rigorous testing } \\
\text { standards. }\end{array}$ \\
\hline $\begin{array}{l}\text { Coombs \& Ryan } \\
\text { (1990) }\end{array}$ & US & $\begin{array}{l}624 \text { College Athletes } \\
\text { (500 drug-tested athletes, } \\
124 \text { intercollegiate athletes } \\
\text { not subject to drug testing) } \\
71 \% \text { male in tested } \\
\text { athletes } \\
50 \% \text { male in comparison } \\
\text { group }\end{array}$ & $\begin{array}{l}\text { Questionnaire (75-items) \& } \\
\text { Sub-Sample Follow-Up } \\
\text { Interview ( } n=57) \\
\text { [Key Themes: beliefs about } \\
\text { drug testing effectiveness; } \\
\text { testing experience] }\end{array}$ & $\begin{array}{l}\text { - } 69 \% \text { believed that urine testing is effective in identifying athletes who use drugs, } \\
\text { though fewer in the comparison group shared this opinion. } \\
\text { - Methods of avoiding a positive test were identified by the college athletes (mainly } \\
\text { referenced to social drugs). } \\
\text { - Physical and psychological side effects associated with drug use were of less a } \\
\text { concern to athletes than the loss of social status associated with a positive drug } \\
\text { test. }\end{array}$ \\
\hline
\end{tabular}


Table 4. Descriptive analysis of studies examining the attitudes of college athletes towards doping in sport.

\begin{tabular}{|c|c|c|c|c|}
\hline Author (year) & Country & Sample & Methods & Summary \\
\hline Diacin et al. (2003) & US & $\begin{array}{l}8 \text { male intercollegiate } \\
\text { athletes } \\
100 \% \text { male } \\
\text { Age range - } 20-22 \text { years } \\
7 \text { Caucasian }\end{array}$ & $\begin{array}{l}\text { Semi-Structured } \\
\text { Interviews } \\
\text { [Key themes: drug use; drug } \\
\text { testing; reinforcement; } \\
\text { attitudes to testing; } \\
\text { pragmatic role acceptance; } \\
\text { organisation deviance; } \\
\text { inductive analysis] }\end{array}$ & $\begin{array}{l}\text { - Athletes generally rejected the use of performance enhancing substances in sport } \\
\text { and supported the drug testing programmes. } \\
\text { - Coaches and peers/team-mates were the primary shapers of beliefs about drug } \\
\text { use. The author use theories of reinforcement developed by Bandura (1977) to } \\
\text { explain these perceptions. } \\
\text { - Athletes believed that representing their university in sport was a privilege and that } \\
\text { drug testing was not an invasion of privacy. } \\
\text { - Athletes believed that testing for certain substances was justified on the basis that } \\
\text { it ensured fair competition. }\end{array}$ \\
\hline $\begin{array}{l}\text { Gray \& Schoof } \\
\text { (1993) }\end{array}$ & US & $\begin{array}{l}140 \text { College Males ( } 70 \\
\text { athletes, } 70 \text { non-athletes) } \\
\text { Demographics not } \\
\text { presented }\end{array}$ & $\begin{array}{l}\text { Questionnaire (34-items) } \\
\text { [Key Themes: Drug testing } \\
\text { beliefs; legal issues; } \\
\text { procedures; athletes vs. non- } \\
\text { athletes] }\end{array}$ & $\begin{array}{l}\text { - Both groups believed that drug testing of athletes was a good idea, because it } \\
\text { prevented unfair advantage. } \\
\text { - Athletes and non-athletes disagreed significantly on the four concepts examined. } \\
\text { - Non-athletes were generally supportive of more stringent treatment for the } \\
\text { offending athlete, more likely to support measures to reduce the athlete's financial } \\
\text { aid and penalise the entire team. }\end{array}$ \\
\hline $\begin{array}{l}\text { Hamilton \& Stone } \\
(1990)\end{array}$ & US & $\begin{array}{l}640 \text { College Students } \\
\text { (non-athletes, } n=559) \\
18-24 \text { years } \\
45 \% \text { males \& } 55 \% \text { females }\end{array}$ & $\begin{array}{l}\text { Questionnaire } \\
\text { [Key Themes: Attitudes } \\
\text { towards drug-testing; } \\
\text { perceived prevalence of drug } \\
\text { use; perceived benefits of } \\
\text { drug use] }\end{array}$ & $\begin{array}{l}\text { - } 90 \% \text { of participants stated it was the right of the college to require drug testing of } \\
\text { intercollegiate athletes. } \\
\text { - } 89 \% \text { agreed that a professional athlete has a duty not to take illegal drugs (similar } \\
\text { value for amateur athletes) } \\
\text { - Overall, } 80 \% \text { believed it was unethical to participate in sports when using } \\
\text { performance enhancing drugs. } \\
\text { - } 61 \% \text { of athletes and } 77 \% \text { of non-athletes believed more college athletes would use } \\
\text { drugs if they were not afraid of losing their eligibility. }\end{array}$ \\
\hline $\begin{array}{l}\text { Issari \& Holman } \\
\text { Coombs (1998) }\end{array}$ & US & $\begin{array}{l}500 \text { Intercollegiate } \\
\text { Athletes } \\
\text { Same sample as Coombs } \\
\text { \& Ryan (1990) and } \\
\text { Coombs \& Coombs (1991) }\end{array}$ & $\begin{array}{l}\text { Questionnaire (75-items) \& } \\
\text { Sub-Sample Follow-up } \\
\text { Interview ( } \mathrm{n}=57) \\
\text { [Key Themes: Gender; } \\
\text { attitudes towards drug- } \\
\text { testing \& use] }\end{array}$ & $\begin{array}{l}\text { - Females were significantly less likely than men to consider drug testing an } \\
\text { invasion of privacy }(P<0.01) \text {, a violation of civil rights }(P<0.001) \text { or unethical } \\
(P<0.001) \text {. } \\
\text { - Females were significantly more likely to support mandatory drug testing for all } \\
\text { intercollegiate and professional athletes. } \\
\text { - Female athletes were more likely to support the banning of athletes who tested } \\
\text { positive for illegal substances, whilst males believed that athletes should be given } \\
2 \text { or more chances following a positive test before being banned. }\end{array}$ \\
\hline
\end{tabular}


Table 4. Descriptive analysis of studies examining the attitudes of college athletes towards doping in sport.

\begin{tabular}{|c|c|c|c|c|}
\hline First author (year) & Country & Sample & Methods & Summary \\
\hline Kersey (1996) & US & $\begin{array}{l}1185 \text { College Athletes } \\
\text { (17-39 years) }\end{array}$ & $\begin{array}{l}\text { Questionnaire (27-items) } \\
\text { [Key themes: prevalence of } \\
\text { AS use; knowledge of AS; } \\
\text { user vs non-user } \\
\text { comparisons; AS use } \\
\text { patterns and profiles] }\end{array}$ & $\begin{array}{l}\text { - Overall rate of AS use was 3.3\% (4.2\% males, } 1.2 \% \text { females) } \\
\text { - } 48 \% \text { of users compared to } 15 \% \text { of non-users considered themselves to be "very } \\
\text { knowledgeable" on AS related matters } \\
\text { - Sources of knowledge: Users - lifting partners \& fellow athletes; non -users - } \\
\text { coaches or instructors }\end{array}$ \\
\hline $\begin{array}{l}\text { Paccagnella \& } \\
\text { Grove (1997) }\end{array}$ & Australia & $\begin{array}{l}106 \text { Sport Science } \\
\text { Students } \\
\text { Mean age }-20.4 \text { yrs } \\
\text { Equal gender mix }\end{array}$ & $\begin{array}{l}\text { Questionnaire (72-items) } \\
\text { [Key themes: attitudes } \\
\text { towards stigmatised athletes; } \\
\text { ascribed personality traits; } \\
\text { high-profile sports } \\
\text { performers] }\end{array}$ & $\begin{array}{l}\text { - Athletes associated with drug use were perceived as less honest and rule } \\
\text { orientated than performers subject to other forms of publicity. } \\
\text { - Drug using athletes were also viewed as lacking in self-control and being uncaring, } \\
\text { especially by male subjects. } \\
\text { - Exemplary behaviour from high profile sports stars expected. } \\
\text { - Athletes who had been sexually stigmatised were generally viewed more positively } \\
\text { than the doping and criminal athletes. }\end{array}$ \\
\hline Pan \& Baker (1998) & US & $\begin{array}{l}237 \text { responses from } \\
\text { college athletes (across } \\
\text { institutions) } \\
\text { Demographics not } \\
\text { reported }\end{array}$ & $\begin{array}{l}\text { Questionnaire (multi- } \\
\text { dimensional-scaling } \\
\text { approach) } \\
\text { [Key themes: side effect } \\
\text { beliefs, relevance to athletic } \\
\text { performance] }\end{array}$ & $\begin{array}{l}\text { - Marijuana, speed, and LSD were popular amongst male students and } \\
\text { amphetamines and morphine among female students. } \\
\text { - Male athletes were well informed about the functions and dysfunctions of AS yet } \\
\text { were still vulnerable to use. }\end{array}$ \\
\hline Peters et al. (2005) & US & $\begin{array}{l}43 \text { self-identified past } \\
\text { ephedra users } \\
30 \text { males, } 13 \text { females }\end{array}$ & $\begin{array}{l}\text { Qualitative study - } \\
\text { interviews } \\
\text { (8 open-ended questions } \\
\text { based on the Theory of } \\
\text { Planned Behaviour) } \\
\text { [Key themes: beliefs and } \\
\text { norms associated with past } \\
\text { ephedra use] }\end{array}$ & $\begin{array}{l}\text { - In this minority sample of athletes, the most frequent reason for use for males was } \\
\text { to increase athletic performance and for females it was weight loss. } \\
\text { - The majority of males athletes believe that it is a personal choice to use ephedra } \\
\text { and most females believed it's the norm among athletes }\end{array}$ \\
\hline
\end{tabular}


Table 4. Descriptive analysis of studies examining the attitudes of college athletes towards doping in sport.

\begin{tabular}{|c|c|c|c|c|}
\hline First author (year) & Country & Sample & Methods & Summary \\
\hline $\begin{array}{l}\text { Schneider \& Morris } \\
\text { (1993) }\end{array}$ & US & $\begin{array}{l}197 \text { College Athletes } \\
(524 \text { questionnaires } \\
\text { administered, } 197 \text { returned } \\
\text { - } 38 \% \text { response rate) } \\
19-24 \text { years } \\
72 \% \text { males, } 28 \% \text { females }\end{array}$ & $\begin{array}{l}\text { Questionnaire (22 items) } \\
\text { [Key Themes: Personal drug } \\
\text { use behaviours; attitudes } \\
\text { towards mandatory testing; } \\
\text { varsity differences; gender } \\
\text { differences] }\end{array}$ & $\begin{array}{l}\text { - } 95 \% \text { of athletes were aware of the Institutions mandatory drug education and } \\
\text { testing programme for athletes. Only } 57 \% \text { knew which drugs were being tested for. } \\
\text { - } 12 \% \text { claimed to be using banned substances (including alcohol) one or more times } \\
\text { a month. } \\
\text { - }>5 \% \text { of athletes claimed to have tried drugs as a performance enhancer. } \\
\text { - } 57 \% \text { of athletes claimed to have experimented will illegal substances at college } \\
\text { (only } 10 \% \text { suggested it was to enhance performance). } \\
\text { - } 56 \% \text { said drug testing discourages drug use by athletes. }\end{array}$ \\
\hline $\begin{array}{l}\text { Spence \& Gauvin } \\
(1996) \\
\text { National survey - } \\
\text { drug and alcohol } \\
\text { use by Canadian } \\
\text { University Athletes }\end{array}$ & Canada & $\begin{array}{l}754 \text { College Athletes } \\
62 \% \text { male, } 38 \% \text { female }\end{array}$ & $\begin{array}{l}\text { Questionnaire (over } 300 \\
\text { items - adapted Anderson } \\
\text { et al. inventory for } \\
\text { Canadian use) } \\
\text { [Key themes: Personal drug } \\
\text { use behaviours; attitudes to } \\
\text { drug testing and drug } \\
\text { education; demographic } \\
\text { characteristics] }\end{array}$ & $\begin{array}{l}\text { - More than } 85 \% \text { of athletes agree or strongly agree with the idea that Canadian } \\
\text { Universities should provide drug and alcohol education programs for athletes. } \\
\text { - } 67 \% \text { of athletes agreed or strongly agreed that drug testing by the CIAU had } \\
\text { deterred drug use. } \\
\text { - Over } 1 / 3 \text { of athletes were unaware of their school's drug education programme. } \\
\text { - Alcohol was the drug most frequently used by all athletes in the last } 12 \text { months } \\
\text { - For the drugs perceived as ergogenic, athletes used more major pain medications } \\
\text { (18\%). Less than } 1 \% \text { of athletes reported using AS (varsity differences noted - } 6 \% \\
\text { males basketballers reported AS use), amphetamines or barbiturates. }\end{array}$ \\
\hline $\begin{array}{l}\text { Tricker \& Connolly } \\
\text { (1997) }\end{array}$ & US & $\begin{array}{l}563 \text { College Athletes } \\
\text { Demographics not } \\
\text { reported }\end{array}$ & $\begin{array}{l}\text { King Drug in Sport } \\
\text { Questionnaire (32-items) } \\
\text { [Key Themes: Attitudinal } \\
\text { factors; 'at-risk' athletes } \\
\text { characteristics; Theory of } \\
\text { Planned behaviour] }\end{array}$ & $\begin{array}{l}\text { - 'At risk' users in this study would use banned substances given the 'right' } \\
\text { circumstances. } \\
\text { - The statement "I would take steroids if I knew that I would not test positive for } \\
\text { using them" accounted for } 60 \% \text { of variance related to intention to use AS. } \\
\text { - Major deterrents for preventing use can be classified within the } 3 \text { areas of the } \\
\text { Theory of Reasoned Action. } \\
\text { - Authors suggest that subjective norms were the strongest deterrent of drug use. }\end{array}$ \\
\hline Yesalis et al. (1990) & US & $\begin{array}{l}1638 \text { College Athletes } \\
\text { Demographics not } \\
\text { reported }\end{array}$ & $\begin{array}{l}\text { Questionnaire } \\
\text { [Key themes: Estimates of } \\
\text { competitors AS use level] }\end{array}$ & $\begin{array}{l}\text { - Mean overall projected rate of use of AS (ever used) across all Division I sports } \\
\text { surveyed was } 12 \% \text { ( } 15 \% \text { males, } 6 \% \text { females) } \\
\text { - American football player respondents reported highest projected use (ever used) } \\
\text { ( } 29 \%) \text {, followed by Track and Field ( } 21 \%) \\
\text { - Only } 3 \% \text { of American football players and } 8.4 \% \text { of track athletes felt their sport had } \\
\text { no problem regarding AS. }\end{array}$ \\
\hline
\end{tabular}




\subsubsection{Discussion}

There is consistent evidence to support the contention that college athletes are engaging in doping practices, though as in other populations, a reliable estimate of prevalence is yet to be established. Still, since 1990, two national surveys have been conducted in Canada and the US and the methodologies employed enabled direct comparisons to be made. Furthermore, although not covered in the detailed analysis presented in this section, tertiary students in a number of European countries were surveyed in an attempt to establish prevalence of drug use and potential precipitating factors (section 3). Although sample size across countries was unequal in this investigation and some EU countries were absent (e.g., Denmark, Sweden, Spain and the UK), doping behaviours were also reported in these countries. Systematic, large scale studies are beginning to emerge and this can only benefit this line of inquiry. However, at the present time the research in this population is heterogeneous and only tentative conclusions can be offered when discussing doping prevalence.

Whilst most college athletes are in favour of taking steps to prevent the use of performance enhancing drugs in their sports, concerns are expressed regarding the effectiveness of mandatory testing as a deterrent. Furthermore, some studies suggest that college athletes question the reliability and integrity of the testing procedures. Despite their reservations, college athletes were largely in favour of increased drug testing and would welcome a more randomised approach to testing selection and delivery. Moreover, college athletes would welcome more and better doping and drug testing information from their own institutions and in the case of the US, the NCAA. Cross-sectional studies suggest that this delivery is paramount in the orientation phase of an education programme, when athletes would like to receive information that they perceive assures them that drug testing is conducted to support, rather than attack, them. Finally, deficits in college athletes' knowledge relating to prohibited substances, doping effects and testing procedures were identified. Clearly, great variation in knowledge will arise across studies, but it is important to undertake objective knowledge evaluations if that is the goal of the education programme.

As highlighted, researchers continue to experience considerable difficulty in establishing an accurate estimate of doping prevalence amongst college athletes, with figures varying widely 
according to the population under study and methodology employed. Given the sensitive nature of the subject matter this is perhaps unsurprising. As with all the target groups studied, the true prevalence of drug use amongst college athletes' likely falls between the upper boundaries of self-reported usage and the lower boundaries of athletes' estimates of usage amongst teammates and competitors. Furthermore, the motives for using doping agents are yet to be fully established. However, maintaining or improving physical functioning, coping with social or psychological pressures or striving for social or psychological goals were motives identified in this population. Understanding the motives for doping violations in college athletes is complicated because studies on this population also include social drugs, making motives for performance enhancing drug use difficult to discriminate. Perhaps the most concerning finding across studies sampled was the suggestion that college athletes would commit a doping violation if the circumstances were right.

Once again, drawing firm conclusions in relation to the attitudes of college athletes to all aspects of sporting drug use is limited by the research methodologies employed. Non-validated questionnaires dominated the literature and this limitation was exacerbated by the fact that the research papers failed to report in detail the content of the questionnaire. Internal reliability, validity and test-retest reliability are psychometric terms that one does not come across readily in this literature. Consequently, one cannot help but question the credibility of the findings. Also, the haphazard approach to surveying college athletes 'attitudes' to doping means that direct comparisons across studies cannot be made. Moreover, a systematic research programme has not been followed by a team of researchers, which itself demonstrates a lack of coherence and continuity in the field. Finally, the term attitudes should be used loosely in this section. On the whole, the knowledge of college athletes has been surveyed rather than their attitudes and the lack of theoretical integration is concerning. Indeed, on the whole, this field does not draw upon psychosocial foundations or the main stream attitude researchers who have been examining the attitude-behaviour relationship for decades in order to understand more empirically the attitudes of this athletic population. 


\section{$4 \quad$ ATTITUDES TOWARDS DOPING}

\subsection{Detailed Analysis - School Children}

\subsubsection{Summary}

Few published studies have considered the attitudes and knowledge of school age athletes in relation to performance enhancing drug use. Again, anabolic steroid use dominated the focus of the investigations conducted and prevalence rates of performance enhancing drug use indicated that doping behaviour is by no means exclusive to elite athletes. Yet, the majority of young people surveyed, both athletes and non-athletes, generally expressed a negative attitude towards doping. There is evidence to suggest a lack of knowledge regarding anabolic steroids and other doping agents amongst this population, which may in part contribute to the decision-making process of some young people to use doping drugs. Very little research has been conducted on the full spectrum of doping agents and scientific literature on young athletes' usage and attitudes towards stimulants, narcotics, diuretics or masking agents is sparse. Again, methodological flaws were evident in research investigating this target group but the information that follows is a detailed analysis of the main findings of peer-reviewed articles that have gone beyond merely reporting prevalence statistics by offering information on high school athletes' attitudes, beliefs and knowledge of doping and drug testing systems.

\subsubsection{Background}

Eight studies examined doping knowledge and attitudes amongst school children. Six were conducted in the United States $25,82,117,123,135,138$, one in Canada 78 and one in France 66 . Five papers focused specifically upon anabolic steroids $25,78,117,123,138$, two addressed recreational and ergogenic drugs 66,82 , and one study examined attitudes towards non-steroidal antiinflammatory drugs (NSAIDs) ${ }^{135}$. A brief descriptive analysis of each study can be found in Table 5 and study annotations are located in Appendix A.

\subsubsection{Sample}

Sample size varied greatly from $604^{135}$ to $16169{ }^{78}$, though it should be noted that seven out of eight studies comprised samples of between 600 and 2200 subjects. Three articles described 
data gathered from the general high school population $78,82,123$, two studies focused solely upon high school American football players 117,135 and the remaining three articles drew subjects from a range of sports $25,66,138$. Five articles indicated that subjects were drawn from high school years 6-12, thus it can be assumed that all subjects were between 11 and 18 years of age 25, 78, 82, 123, 138. Two studies reported that subjects mean age was approximately 16 years 66,135 . Stilger and Yesalis ${ }^{117}$ provided no indication of the subjects' age. Only three papers report ethnicity data, wherein samples were comprised $66 \% 138,85 \% 117$ and 90\% 135 Caucasians. Four studies comprised samples with a fairly equal distribution (40-60\% male) of males and females $25,66,82$, 123, two articles used a sample of predominantly (>60\%) male subjects ${ }^{135,138}$ and two studies did not report on subjects gender 78,117 .

\subsubsection{Methods}

All studies were cross-sectional in nature and administered questionnaires to gather data. Five studies reported that the questionnaire design was informed by the work of previous researchers $66,78,82,135,138$, however, minimal detail is offered in relation to the validity and reliability of the inventories used. Indeed, only two studies report efforts to ensure the validity of the research questionnaire, either through pilot testing 66,117 or through assessment by a panel of experts 117 . Despite rudimentary attempts to ensure the validity and reliability of the scales employed, no study documented an acceptable level of psychometric validation. Key themes that were assessed across the body of research include, patterns of anabolic steroid use 25, 78, 117, 123, 138, recreational or doping drug use 66,82 or use of NSAIDs ${ }^{135}$. Researchers also explored beliefs about the positive and negative effects of doping drugs on athletic performance $66,117,123,135$ or general health $66,117,135$. Availability and sources of doping agents were assessed by a number of researchers $25,117,123,138$. Four studies explored factors related to sports involvement, including type of sport, years of sport involvement, level of performance and perceptions on the incidence of doping in other sports 25,78, 117, 123. Stilger and Yesalis 117 also assessed the types of steroid taken, dosages used and methods of administration. Naylor et al 82 examined the effectiveness of substance use regulations and education interventions, as implemented by the Massachusetts Interscholastic Athletic Association. 


\subsubsection{Findings: Prevalence and reasons for doping}

Prevalence rates for anabolic steroid or other doping drug use ranged from $0.7 \%$ in a sample of pre-adolescent athletes 138 to $6.3 \%$ amongst a group of high school American football players ${ }^{117}$. Across all studies, incidence of drug use was higher in males than females, with availability and usage increasing with age 25,66,78,117,123,138. Two studies support the contention that athletes are more likely to use anabolic steroids than non-athletes 78,123 , whilst Naylor et al 82 found no differences in use between athletes and non-athletes. Terney and McLain 123 report that the sports with the highest incidence of steroid use were American football (9.3\%) and wrestling (12.2\%). Seventy nine percent of respondents indicated that the incidence of doping is increasing 66 . Warner et al 135 indicated that $75 \%$ of high school American footballers had used NSAIDs in the three months prior to investigation, with no differences according to age or race.

Three studies questioned subjects on their reasons for using anabolic steroids, with the most frequently cited motive in all cases being to improve athletic performance, followed by a desire to change or improve physical appearance $78,117,138$. Amongst a sample of American football players, the most frequently cited reasons for choosing not to use steroids were concerns regarding adverse health effects, a contradiction of beliefs or due to fear of being drug tested 117 . Between $11 \% 138$ and $50 \% 25$ of respondents indicated that they could obtain anabolic steroids without difficulty. Sources of anabolic steroids included other athletes or team-mates, coaches, school officials and physicians $25,117,123$.

\subsubsection{Findings: Attitudes towards doping}

Researchers questioned subjects on a number of issues pertaining to attitudes and ethics, which may impact upon their decision to engage in doping behaviour. Whilst no two studies examined the same issues, it is possible to conclude that in general this population disapproved of doping in sport and their self-reported attitude was negative. Melia et al 78 , for example, reported that $74 \%$ of subjects considered that using drugs to improve sporting performance was cheating, corroborated by the finding that $94 \%$ of high school athletes stated that doping is cheating 66 . However, a small proportion of students expressed an inclination towards doping under certain conditions - demonstrating ambivalent attitudes. For example, Corbin et al 25 found that $12 \%$ of boys and $7 \%$ of girls would use anabolic steroids if it would guarantee them an Olympic medal 
and approximately 5\% would use them if they were legal. Similarly, Stilger and Yesalis 117 reported that between $20-50 \%$ of high school American footballers would use steroids if they knew their opponents were also using them. Other indications that young people may be complicit to the use of doping agents were noted by Laure et al ${ }^{66}$, who report that $17 \%$ of respondents believed that a friend would not reproach them for using doping agents and $5 \%$ would take performance enhancing drugs if they were offered them by a friend. Such findings underscore the need to consider prevention approaches to education rather than focusing solely on deterrence approaches 75 .

\subsubsection{Findings: Beliefs regarding the effects of doping}

With regard to the effectiveness of anabolic steroids or other doping agents in improving performance, $54 \%$ of high school students reported that they are effective in increasing strength and speed ${ }^{123}$. Sixty-eight percent of high school athletes 66 and $44 \%$ of pre-adolescent athletes 138 indicated that doping agents are effective in improving sporting performance. However, ninety percent of pre-adolescents stated that they did not believe using steroids would improve their chances of athletic success ${ }^{138}$. Twenty one percent of high school athletes reported that refusing to dope meant losing all chances of becoming a great champion ${ }^{66}$, whilst approximately $3 \%$ of pre-adolescent athletes believed that steroids were needed to improve chances of athletic success ${ }^{138}$.

Awareness of potential negative effects resulting from steroid use varied considerably between studies. For example, Wroble et al 138 reported that $64 \%$ of respondents had received information regarding the possible side effects of steroid use, in contrast to Terney and McLain ${ }^{123}$ who stated that just $43 \%$ of subjects were aware of the medical risks associated with steroid use. There was some evidence to suggest that steroid users were less aware of or less willing to acknowledge that steroid use may be harmful. Melia et al 78 report that $30 \%$ of anabolic-androgenic users believed that steroids are not harmful. However, only $6 \%$ of non-users shared the same belief. Similarly, Laure et al 66 noted that $49 \%$ of subjects, who had used doping agents previously, as compared to only $6 \%$ of non-users, indicated that doping is not always hazardous to health. Furthermore, $27 \%$ of respondents believed that doping agents could be used without risk to health if supervised by a physician, with this percentage increasing for boys as compared to girls 
(31\% vs. $22 \%$ ) and for those who had already used drugs compared to non-users (46\% vs. $27 \%$ ). One of the most startling findings was reported by Melia et al 78 - $29 \%$ of anabolic-androgenic steroid users who administered drugs by injection admitted to sharing needles with fellow users. 
Table 5. Descriptive analysis of studies examining the attitudes of school age children/athletes towards doping in sport.

\begin{tabular}{|c|c|c|c|c|}
\hline $\begin{array}{c}\text { First author } \\
\text { (year) }\end{array}$ & Country & Sample & Methods & Summary \\
\hline $\begin{array}{l}\text { Laure et al. } \\
\text { (2004) }\end{array}$ & France & $\begin{array}{l}1459 \text { high school athletes } \\
\text { Mean age = } 16 \text { years }\end{array}$ & $\begin{array}{l}\text { Questionnaire } \\
\text { [Key themes: drug use; attitudes } \\
\text { towards doping and psycho- } \\
\text { sociological factors associated } \\
\text { with the use of drugs and doping } \\
\text { agents] }\end{array}$ & $\begin{array}{l}\text { - } 4 \% \text { of subjects stated they had used doping agents at least once, } \\
\text { - Drug use increased with age and level of competition and was higher in boys. } \\
\text { - } 7 \% \text { believed doping was not always hazardous to health (particularly boys, } \\
\text { athletes }>18 \text { years of age and those who had used doping practices previously). } \\
\text { - } 68 \% \text { of athletes believed that doping is effective in improving sport performance. } \\
\text { - } 21 \% \text { believed that refusal to use doping practices meant losing all chances of } \\
\text { becoming a great champion. } \\
\text { - } 27 \% \text { of subjects believed supervision by a physician meant doping could be } \\
\text { practised without health risks } \\
\text { - Athletes who admitted using doping agents were more likely to have bad } \\
\text { relations with their parents, feel disliked by classmates and feel unhealthy. }\end{array}$ \\
\hline $\begin{array}{l}\text { Corbin et al } \\
\text { (1994) }\end{array}$ & US & $\begin{array}{l}1690 \text { high school athletes } \\
\text { Grades 8-11 } \\
60 \% \text { males }\end{array}$ & $\begin{array}{l}\text { Questionnaire (10 items) } \\
\text { [Key themes: AAS use; } \\
\text { characteristics of AAS users; } \\
\text { attitudes; availability; peer } \\
\text { influence] }\end{array}$ & $\begin{array}{l}\text { - Males reported greater availability and were more likely to know someone who } \\
\text { sold them or used them. } \\
\text { - } 8 \% \text { of males, compared to } 2 \% \text { of females would use AAS if they were legal. } \\
\text { - } 10 \% \text { indicated they would use AAS if it would guarantee them an Olympic } \\
\text { medal. } \\
\text { - Previously considering steroid use, a willingness to use them if they were legal } \\
\text { and a willingness to use them if they could ensure success in sports were the } \\
\text { most useful in classifying athletes as steroid users versus non-users. } \\
\text { - } 2.4 \% \text { of males and } 1.1 \% \text { of females had used AAS. }\end{array}$ \\
\hline Melia et al (1996) & Canada & $\begin{array}{l}16169 \text { high school } \\
\text { students } \\
11-18 \text { years }\end{array}$ & $\begin{array}{l}\text { Questionnaire (42 items) } \\
\text { [Key themes: prevalence of use } \\
\text { of performance enhancing drugs, } \\
\text { (particularly AS); knowledge and } \\
\text { attitudes] }\end{array}$ & $\begin{array}{l}\text { - } 29 \% \text { of users, compared to just } 6 \% \text { of non-users, believed that steroid use would } \\
\text { not harm them. } \\
\text { - } 74 \% \text { of students strongly agreed that using drugs to do better in sport was } \\
\text { cheating. } \\
\text { - Overall prevalence of steroid use was } 2.8 \% \text { ( } 1.5 \% \text { to improve performance and } \\
1.3 \% \text { to alter body image). } \\
\text { - Prevalence greater for males and increased with age and involvement in } \\
\text { competitive sport. }\end{array}$ \\
\hline $\begin{array}{l}\text { Naylor et al } \\
(2001)\end{array}$ & US & $\begin{array}{l}1515 \text { high school students } \\
\text { (representing } 15 \text { schools) } \\
\text { Response rate not reported } \\
\text { Evenly distributed by gender } \\
\text { and across grades } 9-12\end{array}$ & $\begin{array}{l}\text { Questionnaire (150-items) } \\
\text { [Key themes: Drug use; } \\
\text { effectiveness of MIAA rules and } \\
\text { educational interventions] }\end{array}$ & $\begin{array}{l}\text { - Athletes were less likely to use recreational drugs than non-athletes. } \\
\text { - No differences in usage of AAS between athletes and non-athletes. } \\
\text { - } 32 \% \text { of athletes were not aware of the local rule prohibiting the use of } \\
\text { recreational or ergogenic drugs during the athletic season. } \\
\text { - } 38 \% \text { reported violation of the Chemical Health Eligibility rule. } \\
\text { - } 71 \% \text { of athletes believed that some of their team-mates had violated this rule. } \\
\text { - } 31 \% \text { expressed interest in drug education initiatives provided by the athletic } \\
\text { department. }\end{array}$ \\
\hline
\end{tabular}


Table 5. Descriptive analysis of studies examining the attitudes of school age children/athletes towards doping in sport.

\begin{tabular}{|c|c|c|c|c|}
\hline Study & Country & Sample & Methods & Summary \\
\hline $\begin{array}{l}\text { Stilger \& Yesalis } \\
\text { (1999) }\end{array}$ & US & $\begin{array}{l}873 \text { high school American } \\
\text { football players } \\
\text { (representing } 27 \text { schools) } \\
\text { Response rate }=66 \%\end{array}$ & $\begin{array}{l}\text { Questionnaire ( } 50 \text {-items) } \\
\text { [Key themes: knowledge \& } \\
\text { attitude toward use of AAS, } \\
\text { motives for use; personal use; } \\
\text { administration of AAS] }\end{array}$ & $\begin{array}{l}\text { - No difference in AAS use between urban, suburban and rural schools. } \\
\text { - } 49 \% \text { of users reported improvement in performance as the primary reason for } \\
\text { use, } 29 \% \text { stated improved appearance. } \\
\text { - Off those that discontinued use, } 43 \% \text { did so because of adverse health effects, } \\
28 \% \text { were afraid of being drug tested and } 11 \% \text { said it was against their beliefs. } \\
\text { - } 54 \% \text { of users indicted that "I would use anabolic androgenic steroids if I knew } \\
\text { opponents playing against me were using them" compared to } 22 \% \text { of non-users. } \\
\text { - } 41 \% \text { of steroid users listed a physician or coach as their primary source for } \\
\text { obtaining steroids. }\end{array}$ \\
\hline $\begin{array}{l}\text { Terney \& McLain } \\
(1990)\end{array}$ & US & $\begin{array}{l}2113 \text { high school students } \\
\text { Evenly distributed by gender } \\
\text { and across grades } 9-12\end{array}$ & $\begin{array}{l}\text { Questionnaire (29-items) } \\
\text { [Key themes: knowledge, } \\
\text { attitudes, personal use and } \\
\text { availability of anabolic steroids; } \\
\text { perceptions of use by others] }\end{array}$ & $\begin{array}{l}\text { - } 5.5 \% \text { of athletes reported steroid use compared to } 2.4 \% \text { of non-athletes. } \\
\text { - Usage greater in males than females. } \\
\text { - Highest incidence of steroid use - American football and wrestling. } \\
\text { - } 2 \% \text { of athletes stated that a coach or faculty member had suggested that they } \\
\text { use steroids. } \\
\text { - } 10 \% \text { indicated they would use steroids to help in high school sport } \\
\text { - } 9 \% \text { would use them to obtain an athletic scholarship. } \\
\text { - Sources of information - television ( } 34 \%), \text { friends ( } 27 \%) \text {, 'muscle' magazines } 6 \% \\
\text { and physicians (4.8\%). } \\
\text { - AAS use - } 6.5 \% \text { percent in males and } 2.5 \% \text { in females (4.4\% overall). }\end{array}$ \\
\hline $\begin{array}{l}\text { Warner et al } \\
(2002)\end{array}$ & US & $\begin{array}{l}604 \text { High School American } \\
\text { Football Players } \\
\text { Response rate }=55 \% \\
\text { Mean age }=15.8 \text { years, } 90 \% \\
\text { white }\end{array}$ & $\begin{array}{l}\text { Questionnaire } \\
\text { [Key themes: prevalence, } \\
\text { knowledge, attitudes towards } \\
\text { NSAIDS; users vs. non-users] }\end{array}$ & $\begin{array}{l}\text { - } 75 \% \text { of subjects reported using NSAIDS in the previous } 3 \text { months and } 15 \% \\
\text { report daily use. } \\
\text { - Daily users were more likely to believe that NSAIDS improved their performance, } \\
\text { to have decided independently to use them and used them to block pain before it } \\
\text { occurred rather then as treatment for it. }\end{array}$ \\
\hline $\begin{array}{l}\text { Wroble et al } \\
\text { (2002) }\end{array}$ & US & $\begin{array}{l}1553 \text { pre-adolescent } \\
\text { athletes } \\
\text { Response rate }=76 \% \\
10-14 \text { years, } 70 \% \text { males, } \\
66 \% \text { Caucasian }\end{array}$ & $\begin{array}{l}\text { Questionnaire (20-items) } \\
\text { [Key themes: AS prevalence, } \\
\text { knowledge, and attitudes; } \\
\text { information sources of AS; } \\
\text { acquiring AS; } 1989 \text { survey] }\end{array}$ & $\begin{array}{l}\text { - > } 1 \% \text { reported current or previous use of AS } \\
\text { - Higher prevalence amongst males (0.9\%) than females }(0.2 \%) \text {. } \\
\text { - Reasons for use - improve athletic performance, improve personal appearance } \\
\text { and peer pressure. } \\
\text { - } 66 \% \text { of athletes believed that AS would not improve their performance } \\
\text { - } 90 \% \text { stated that they did not need to use AS to be successful in their chosen } \\
\text { - Dport. } \\
\text { - Drug information sources - books \& magazines, parents, coaches, teachers. } \\
\text { - } 30 \% \text { believed Olympic athletes used AS to make the team, whilst } 25 \% \text { believed } \\
\text { college athletes also used AS to make the team. }\end{array}$ \\
\hline
\end{tabular}




\subsubsection{Discussion}

A consistent focus of this body of literature is the use of anabolic steroids in this target group. Additionally, studies have supplemented this research question by considering high school athletes and non-athletes attitudes towards and knowledge of anabolic steroid use. Usage rates varied, but once again indicated that doping behaviour is occurring. Indeed, studies in this domain identify a population at risk and Terney \& McLain ${ }^{123}$ conclude there is a "serious, as yet unappreciated drug problem in our adolescents" (p. 99). Furthermore, steroid use appears to be greater in males than females and to increase with age.

It is encouraging to note that the majority of young people, both athletes and non-athletes, generally expressed a negative attitude towards doping; with the identification that the use of doping agents is unethical in the sporting arena and potentially hazardous to ones health. Despite this, a small percentage of respondents, across the body of research sampled, expressed an inclination towards the use of steroids and other doping agents in the event of changes in the law or on the proviso that such an act would allow them to achieve their sporting goals. It was also evident that a small, but notable proportion of young people (especially those who have engaged in doping behaviour previously), minimise the potential health consequences of their actions, distrust the advice given by physicians or health professional or simply choose to ignore them. This perhaps highlights that even amongst young athletes the pressures and rewards associated with sporting success, whether actual or perceived, are sufficient to at least contemplate engaging in doping behaviour.

There is evidence to suggest a lack of knowledge regarding anabolic steroids and other doping agents amongst this population, which may in part contribute to the decision-making process of some young people to use doping drugs. For example, between $50-70 \%$ of respondents across three investigations believed that anabolic steroids 123,138 or doping agents 66 could improve speed or strength and sporting performance, though this is only possible when combined with appropriate dietary conditions and intensive training. Perhaps of greatest concern regarding young peoples lack of knowledge is the finding reported by Melia et al 78 that almost one third of anabolic steroid users who administering drugs by injection were sharing needles with other users, presumably unaware of the serious risks associated with this practice. Improving young 
people's knowledge of the effects of doping agents, both positive and negative, should be included in any programme intended to reduce doping behaviour.

In addition to the limitation of studies relying almost exclusively upon self-report methods for data collection, a number of studies reviewed in this section have relied on coaches, or support staff, to administer and collect the questionnaires and this may exacerbate the issue of selfpresentation bias. Furthermore, in addition to methodological weaknesses, it should also be noted that very little research has been conducted on the full spectrum of doping agents. Specifically, the scientific literature examining young athletes' usage and attitudes towards stimulants, narcotics, diuretics or masking agents is sparse. Finally, and perhaps most importantly, owing to the cross-sectional nature of existing research and lack of theoretical frameworks guiding the research question, it has not been possible to describe the development of attitudes or drug using behaviour. A longitudinal approach may be instrumental in devising effective interventions to reduce doping behaviour amongst young athletes. 


\section{$4 \quad$ ATTITUDES TOWARDS DOPING}

\subsection{Detailed Analysis - Bodybuilders, Powerlifters \& Gym users}

\subsubsection{Summary}

The use of anabolic steroids within the bodybuilding and weight lifting community has been the foci of research efforts in this population. In parallel with the prevalence enquiries, a number of studies have surveyed motives for use and attitudes towards anabolic steroid use and drug testing. On balance, the evidence suggests that the majority of steroid users are knowledgeable and assert that usage elicits the desired effects. Infact, the potentially detrimental consequences appear outweighed by the perceived benefits in this population. A widespread mistrust of the medical and scientific community is evident; compromising this community's integrity and authority in the eyes of this sub-culture, many of whom have experienced first hand the effects of steroids in increasing muscle mass, enhancing performance and improving self-efficacy. Indeed, it was apparent across a number of studies that bodybuilders and powerlifters, particularly those using steroids, consider existing prevention and testing strategies to be ineffective. Consistent with the prior analysis sections, the research designs employed do not sit at the highest level of the research hierarchy and with the exception of one study, which employed an ethnography approach, all were cross-sectional in nature, utilised non-validated questionnaires and employed basic statistical analysis. However, qualitative research featured more in this population, thus facilitating the collection of 'richer' data. The information that follows is a detailed analysis of the main findings of peer-reviewed articles that have gone beyond merely reporting prevalence statistics by offering information on bodybuilders/powerlifters and gym-users attitudes towards and knowledge of doping and drug testing systems.

\subsubsection{Background}

Thirteen papers met the selection criteria and examined the knowledge and attitudes of bodybuilders, powerlifters and/or gym users. Nine studies were conducted in the United States $13,26,59,86,87,98,105,130,134$, two in the UK ${ }^{80,137}$, one in Sweden ${ }^{69,134}$ and one in the West Indies ${ }^{74}$. All studies examined attitudes of the target group towards the use of anabolic steroids, except 
Pope et al ${ }^{98}$ who assessed steroid users' attitudes towards physicians. A brief descriptive analysis of these studies is shown in Table 6 and a study annotation can be found in Appendix A.

\subsubsection{Sample}

Sample size varied from 1086,87 to $1062^{74}$, though when the latter study was excluded from analysis sample size fell within the range of 10 to 309 130. However, the Van Raalte study was a mixed sample and only comprised 22 bodybuilders and powerlifters. Therefore, Kersey 59 represented the largest sample of this population ( $n=185)$. Including the full sample of Van Raalte ${ }^{130}$, sample size totalled 2103 across all studies, with a mean of 162 subjects per study. This mean figure falls to 62 (total $n=744$ ) if only the sample of bodybuilders/powerlifters from the Van Raalte study is taken into account and the Maharaj et al ${ }^{74}$ study is not included in the sample size analysis.

Eight studies used samples comprised solely of males $13,26,69,86,87,98,105,130$ and three papers report samples with $75-95 \%$ of subjects being male $59,80,137$. Maharaj et al ${ }^{74}$ gathered data from a roughly equal proportion of males and females (48\% male). Wagman et al ${ }^{134}$ did not report subjects' gender, but in view that the entire sample was drawn from elite powerlifters it is proposed that males predominated. Whilst subjects' age varied considerably across the body of research (17 - 68 years) ${ }^{130,137}$, the majority of subjects fell within the range of $20-30$ years of age $13,26,74,86,87,98,105,130,137$. Monaghan 80 and Wagman et al 134 did not report subjects' age. From the seven studies that identified ethnicity $13,26,59,80,86,87,98$, six comprised $>70 \%$ Caucasian subjects $13,26,80,86,87,98$.

\subsubsection{Methods}

All studies used a cross-sectional survey design, with the exception of Monaghan 80 who utilised an ethnography approach. Ten papers employed a questionnaire to gather data, administered either by post 26 , through a magazine ${ }^{13}$ or person to person $13,59,69,74,105,130,134$. Olrich and colleagues ${ }^{86,87}$ gathered data using in-depth interviews and these were also employed by Pope et al ${ }^{98}$ to supplement questionnaire data. Seven studies devised questionnaires tailored to the specific research aims of the study at hand $13,26,59,69,74,98,137$ and only Curry and Wagman 26 report taking steps to ensure questionnaire validity. Van Raalte et al 130 employed the Steroid 
Perception Questionnaire (SPQ) ${ }^{107}$, Wagman et al ${ }^{134}$ used the King Drugs in Sport Questionnaire (KDSQ) ${ }^{61}$ and Schwerin and Corcoran 105 utilised the Beliefs about Steroids Scale (BASS) 20 .

The SPQ is an 18-item inventory that assesses subjects' perceptions of a target individuals arousal and aggression, intelligence, relaxation and tension reduction, sexual enhancement, social assertiveness and global positive effects on a 4-point scale from 'definitely true' to 'definitely false'. The reliability of this inventory is questionable as research has indicated that the internal consistencies of a number of subscales are weak ${ }^{106}$. The KDSQ assesses subjects' knowledge about anabolic steroids, side-effects, where to get these drugs and personal steroid use and had undergone initial psychometric validation during a doctoral thesis ${ }^{61}$ The BASS is a 40-item inventory in which subjects rate statements concerning the physical and psychological effects of anabolic steroid use on a 4-point Likert-type scale. The SPQ and KDSQ have been validated in previous research 20,107. At the time of study, the BASS was still under construction and had not been fully cross-validated. To date, few empirical studies have administered these scales and those that have employed them in their investigations have not reported the internal consistencies of the items.

Researchers tended to focus upon a series of general themes when designing their questionnaires. Most studies examined subjects' knowledge $13,59,74$, attitudes $69,74,137$, or experiences with use of anabolic steroids $26,59,74,86,87$. Three studies examined subjects experiences and attitudes towards drug education and/or testing 13, 26, 134. Three studies sought to understand reasons for steroid use $74,80,137$. Four articles examined users' perceptions of the physical and psychological effects of steroid use 13,86,87,137. Two studies examined steroid users' attitudes towards other drug users ${ }^{130}$ or physicians ${ }^{98}$.

Direct comparison of findings from across the body of research is not possible due to considerable variation in the research methodologies used to gather data. Accordingly, findings will be examined under broad headings such that general trends in the evidence can be summarised. 


\subsubsection{Findings: Reasons for doping (anabolic steroids)}

On balance, motivating factors for engaging in anabolic steroid use were fairly consistent across the seven studies that considered this question $13,59,74,80,87,134,137$. The most frequently cited reasons were to increase body size ${ }^{59,137}$, or strength ${ }^{13}$ and to improve performance or overcome a plateau 87,134 . Only one study noted that 'to improve physical appearance' was the most frequent reason for anabolic steroid use ${ }^{74}$. Monaghan 80 reported that bodybuilders in his research utilised 'self-fulfilment accounts' to explain their drug use behaviours, wherein anabolic steroid use is viewed as a legitimate means of achieving their desired body shape.

\subsubsection{Findings: Beliefs regarding the effects of doping (anabolic steroids)}

In describing the perceived and actual effects of anabolic steroids, subjects' responses can be summarised under headings of 'physical',' psychological' and 'social'. Subjects from six studies reported improvements in physical characteristics such as increased strength $87,105,134,137$, muscle mass $74,87,137$, libido 87 , improved athletic performance 59 , improved recovery 134 and decreased body fat 87,134 . Less desirable 'side-effects' of steroid use were also reported, including being injured more frequently 87 fluid retention ${ }^{87}$, increased aggression, mood swings, hypertension and gynecomastia 26 . Two papers report that between $70-80 \%$ of steroid users experienced side effects, but failed to specify exactly what they were 69,134 . Awareness of a range of side-effects, such as acne, hypertension, increased facial hair amongst women, liver damage and sexual problems were reported in two studies 74,134 , though the proportion of respondents who experienced such effects first hand was not indicated. Olrich ${ }^{86}$ and Olrich and Ewing 87 comment that the physical gains associated with steroid use lead to enhanced social recognition and acceptance for users within the bodybuilding community. Such 'social' effects serve to reinforce steroid use in a similar manner to the more tangible physical outcomes.

Notable differences in the perceived effects of anabolic steroids were observed when responses from users and non-users were compared. Overall, users held a much more positive opinion of steroid use, being more likely to recognise positive effects and minimise negative ones $59,80,105$, 134, 137. For example, Kersey ${ }^{59}$ states that $84 \%$ of users compared to $69 \%$ of non-users felt that anabolic steroids increased athletic performance. Schwerin and Corcoran ${ }^{105}$ conclude "AS (anabolic steroid) users overwhelmingly have greater beliefs about the positive effects of AS use 
than do non-users" (p.223). Two studies revealed that steroid users were significantly more knowledgeable about anabolic steroids than non-users 69,74 . When asked to rate their knowledge on steroids, $48 \%$ of users considered themselves "very knowledgeable" compared to just $12 \%$ of non-users ${ }^{59}$. Opinion was also split with regard to the safety of steroid use. Non-users were more likely to indicate that sufficient scientific evidence exists to support the contention that anabolic steroids are hazardous to health, whereas users suggested that more conclusive research was required 13,105 .

\subsubsection{Findings: Attitudes towards doping prevention and testing}

Only three studies examined attitudes towards drug testing and prevention $13,26,134$, however, there was a consensus amongst steroid users that current prevention efforts are ineffective and detection through testing could be avoided. Curry and Wagman ${ }^{26}$ report that 14 out of 15 elite powerlifters indicated that someone they suspected of steroid use had passed a drug test at National or International competition. Qualitative comments corroborated this assertion, for example one subject stated that "Many detection circumvention techniques are (and have been) prevalent for years" and "Yes, I know this for a fact. I've done it". A further six subjects indicated that they had personally avoided detection when using steroids. Yet, comparison of users and non-users perception of doping prevention efforts revealed conflicting findings. Ardito et al ${ }^{13}$ stated that non-users were more likely to perceive drug testing in sport as being effective in discouraging anabolic steroid use. In contrast, Wagman et al ${ }^{134}$ reported that non-users (80\%) were more inclined than users (60\%) to believe that current doping controls were ineffective, though it should be noted that this difference failed to attain statistical significance. In a study conducted by Wagman and colleagues ${ }^{134}$, non-users $(100 \%)$ were also more likely than users $(60 \%)$ to report that they would not be prepared to compete if there were no doping controls. Interestingly, more users (80\%) than non-users (60\%) reported that they would prefer a situation where no performance enhancing drugs were allowed and in which the detection methodology was 100\% effective. Further investigation of users and non-users attitudes towards drug testing may help clarify the conflicting evidence that is apparent in places. 


\subsubsection{Findings: Attitudes towards other users and physicians}

Three studies noted that anabolic steroid users have little trust in the knowledge of physicians and/or the wider scientific community 13,98,105. Pope et al 98 found that whilst steroid users gave physicians high ratings on knowledge about general health, cigarette smoking, alcohol and conventional illicit drugs, they rated them markedly and significantly lower for their knowledge of anabolic steroids. Wright et al 137 and Ardito et al ${ }^{13}$ report that steroid users mistrust the information provided by the medical community and feel that further research is needed to support the belief that steroid use is harmful.

Van Raalte et al 130 examined the attitudes of steroid users and non-users towards other athletes and drug users. Using the SPQ, steroid users viewed fellow users in a positive light, rating them similarly to a diet conscious athlete, and significantly more positively than a cocaine user. Whilst findings were not so conclusive, there was evidence to suggest that non-users do not view steroid users negatively, or differently from non-using athletes, and rate them more positively then a cocaine user. Monaghan ${ }^{80}$ uncovered similar findings, wherein steroid using bodybuilders distanced themselves from other 'recreational' drug users by asserting that steroid use was a means to an end rather than an end in itself. 
Table 6. Descriptive analysis of studies examining the attitudes of bodybuilders, powerlifters and gym-users towards doping in sport.

\begin{tabular}{|c|c|c|c|c|}
\hline $\begin{array}{l}\text { First author } \\
\text { (year) }\end{array}$ & Country & Sample & Methods & Summary \\
\hline Ardito et al (1994) & US & $\begin{array}{l}20 \text { Bodybuilders } \\
10 \text { steroid users and } 10 \\
\text { non-users } \\
90 \%>30 \text { years old } \\
70 \% \text { Caucasian }\end{array}$ & $\begin{array}{l}\text { Questionnaire } \\
\text { [Key themes: perceptions of } \\
\text { bodybuilders regarding benefits of } \\
\text { AS use and AS prevention and } \\
\text { education programmes; } \\
\text { perceptions of AS research efforts] }\end{array}$ & $\begin{array}{l}\text { - } 40 \% \text { to enhance athletic performance, } 50 \% \text { to increase strength/size. } \\
\text { - Only } 20 \% \text { of users stated that steroid use could be detrimental to health } \\
\text { compared to } 80 \% \text { of non-users. } \\
\text { - Overall, } 85 \% \text { said supplements could not be as effective as AS use. } \\
\text { - Only } 30 \% \text { of steroid users believed that drug testing was effective. } \\
\text { - Users and non-users agreed that sufficient medical research exists to support } \\
\text { the belief that steroids work } \\
\text { - } 90 \% \text { of users reported that there was insufficient evidence to support the belief } \\
\text { that steroids could be harmful. } \\
\text { - Only } 3 \text { out of } 20 \text { subjects had attended a steroid prevention or education } \\
\text { programme. }\end{array}$ \\
\hline $\begin{array}{l}\text { Curry \& Wagman } \\
\text { (1999) }\end{array}$ & US & $\begin{array}{l}15 \text { US Powerlifters } \\
\text { Response rate }-60 \% \\
\text { Age range }-23 \text { to } 45 \\
\text { years }\end{array}$ & $\begin{array}{l}\text { Questionnaire } \\
\text { [Key themes: use of and } \\
\text { experience with anabolic steroids; } \\
\text { effectiveness of doping controls; } \\
\text { attitudes regarding competing with } \\
\text { or without doping control] }\end{array}$ & $\begin{array}{l}\text { - } 10 \text { respondents admitted to having used anabolic steroids and } 5 \text { had beaten the } \\
\text { IOC doping control procedures. } \\
\text { - All subjects indicted that they suspected steroid use amongst other Powerlifters } \\
\text { at National and International competitions, accompanied by comments that } \\
\text { subjects 'knew for a fact' this was happening and that it was 'no secret' and they } \\
\text { had 'done it'. } \\
\text { - } 10 \text { respondents stated that steroids could be used in sufficient dosage to } \\
\text { improve performance without hazard to health. } \\
\text { - } 11 \text { subjects reported that they would prefer a situation where no performance } \\
\text { enhancing drugs were allowed and detection was } 100 \% \text { effective. }\end{array}$ \\
\hline Kersey (1993) & US & $\begin{array}{l}185 \text { private health club } \\
\text { I gym users }\end{array}$ & $\begin{array}{l}\text { Questionnaire } \\
\text { [Key themes: strength training } \\
\text { habits; use and knowledge of } \\
\text { anabolic steroids; users vs. non } \\
\text { users] }\end{array}$ & $\begin{array}{l}\text { - } 48 \% \text { of users reported being 'very knowledgeable' on the subject of steroids } \\
\text { compared to just } 12 \% \text { of non-users. } \\
\text { - Primary source of knowledge on anabolic steroids was 'magazines / trade } \\
\text { literature' for non-users and 'lifting partners' for users. } \\
\text { - } 84 \% \text { of users and } 69 \% \text { of non-users felt that anabolic steroids could improve } \\
\text { athletic performance. } \\
\text { - } 44 \% \text { percent of users and } 17 \% \text { of non-users reported that between } 50-80 \% \text { of } \\
\text { people they knew were using steroids. }\end{array}$ \\
\hline
\end{tabular}


Table 6. Descriptive analysis of studies examining the attitudes of bodybuilders, powerlifters and gym-users towards doping in sport.

\begin{tabular}{|c|c|c|c|c|}
\hline $\begin{array}{c}\text { First author } \\
\text { (year) }\end{array}$ & Country & Sample & Methods & Summary \\
\hline $\begin{array}{l}\text { Lindström et al } \\
\text { (1990) }\end{array}$ & Sweden & $\begin{array}{l}138 \text { Bodybuilders } \\
\text { (53 current or previous } \\
\text { anabolic steroid users) }\end{array}$ & $\begin{array}{l}\text { Questionnaire (49-items) } \\
\text { [Key themes: knowledge and } \\
\text { attitudes concerning use of AS; } \\
\text { prevalence of use; steroid user vs } \\
\text { non-steroid user] }\end{array}$ & $\begin{array}{l}\text { - 94\% of all respondents considered anabolic steroids to be dangerous; for steroid } \\
\text { users this was only the case if consumed in high doses. } \\
\text { - Steroid users were more likely to be training for competition than non-users and } \\
\text { showed significantly greater knowledge than non-users. } \\
\text { - 39\% of current steroid users indicated that they planned to continue usage in the } \\
\text { future. } \\
\text { - Non-users were more likely to be involved in body building to improve well-being } \\
\text { or increase muscle volume. }\end{array}$ \\
\hline $\begin{array}{l}\text { Maharaj et al } \\
(2000)\end{array}$ & $\begin{array}{l}\text { West } \\
\text { Indies }\end{array}$ & $\begin{array}{l}1062 \text { Recreational Gym } \\
\text { Users } \\
48.3 \% \text { male, } 52.7 \% \\
\text { female } \\
50 \% \text { of subjects aged } \\
20-29\end{array}$ & $\begin{array}{l}\text { Questionnaire } \\
\text { [Key themes: Motives for use; } \\
\text { knowledge of AS effects; attitude } \\
\text { towards regulations; AS practices] }\end{array}$ & $\begin{array}{l}\text { - Knowledge of anabolic steroids was greater amongst males and steroid users. } \\
\text { - } 66 \% \text { indicated that anabolic steroids should be banned in competition, } 6.4 \% \text { that } \\
\text { steroids should be allowed in competition and } 27 \% \text { expressed no opinion on this } \\
\text { matter. } \\
\text { - } 69 \% \text { reported that steroids should only be available with a prescription. } \\
\text { - The most frequently cited reason for steroid use was to improve physical } \\
\text { appearance. } \\
\text { - Prevalence of lifetime steroid use was } 2.9 \%(95 \% \mathrm{Cl} 2.0-4.1) \text {, with significantly } \\
\text { greater usage amongst males than females. }\end{array}$ \\
\hline Monaghan (2002) & UK & $\begin{array}{l}67 \text { Bodybuilders and } \\
\text { weight trainers } \\
\text { undertook the } \\
\text { interview element of } \\
\text { this research study } \\
\text { Males - } 91 \%\end{array}$ & $\begin{array}{l}\text { Ethnography and depth audio- } \\
\text { recorded interviews ( } \mathrm{n}=67 \text { ) } \\
\text { [Key themes: Vocabularies of } \\
\text { motive for use of anabolic steroids; } \\
\text { sociological perspective; social } \\
\text { constructions; 'safe' and 'risky' } \\
\text { steroid practices; justification in } \\
\text { contrast to excuse, analytic } \\
\text { induction] }\end{array}$ & $\begin{array}{l}\text { - } 60 \% \text { of respondents reported using or having used AS. } \\
\text { - } 3 \text { main justifications for use were (1) self-fulfilment accounts, (2) condemnation } \\
\text { of condemners and (3) a denial of injury. } \\
\text { - Steroid use was justified as a means to an end, distinct from recreational drug } \\
\text { use. } \\
\text { - Observers that passed negative judgements on those using steroids were } \\
\text { rejected on the basis that condemners were likely to be in poor physical } \\
\text { condition, engaged in more common risk practices (e.g. smoking, drinking } \\
\text { alcohol) and be ignorant about steroids. } \\
\text { - Steroid use was justified on the grounds that it was not injurious to health. Usage } \\
\text { was informed by a collective body of knowledge held by experienced members } \\
\text { of the bodybuilding community. }\end{array}$ \\
\hline
\end{tabular}


Table 6. Descriptive analysis of studies examining the attitudes of bodybuilders, powerlifters and gym-users towards doping in sport.

\begin{tabular}{|c|c|c|c|c|}
\hline $\begin{array}{l}\text { First author } \\
\text { (year) }\end{array}$ & Country & Sample & Methods & Summary \\
\hline Olrich (1999) & US & $\begin{array}{l}10 \text { male bodybuilders } \\
\text { (5 users and } 5 \\
\text { discontinued users) } \\
\text { Varied education levels } \\
\text { and ages }\end{array}$ & $\begin{array}{l}\text { Qualitative Interviews } \\
\text { [Key themes perceived benefits of } \\
\text { steroid use; psychological } \\
\text { dependency; Mishkind et al.'s } \\
\text { (1987) framework; mesomorphic } \\
\text { body type; masculinity] }\end{array}$ & $\begin{array}{l}\text { - All subjects agreed that there is a strong psychological dependency involved } \\
\text { with steroid use. } \\
\text { Dependence experienced through a desire to maintain the benefits accrued } \\
\text { through steroid use and an urge to avoid the negative consequences associated } \\
\text { with loss of muscle upon termination. } \\
\text { - Social gains associated with increased muscle size, such as increased peer } \\
\text { recognition and social status were important. } \\
\text { - The author contends that termination of steroid use not only results in loss of } \\
\text { muscle mass but also peer recognition, self-confidence and social status. }\end{array}$ \\
\hline $\begin{array}{l}\text { Orlich \& Ewing } \\
\text { (1999) }\end{array}$ & US & $\begin{array}{l}10 \text { male bodybuilders } \\
\text { (5 users and } 5 \\
\text { discontinued users) } \\
\text { Same sample reported } \\
\text { upon by Orlich (1999) }\end{array}$ & $\begin{array}{l}\text { Qualitative Interviews } \\
\text { [Key themes: experience of AS use } \\
\text { period, reasons for initiating use; } \\
\text { perceptions of the psychological } \\
\text { and physical effects] }\end{array}$ & $\begin{array}{l}\text { - 9/10 subjects described their experience in a very positive manner. } \\
\text { - Physical, psychological and social benefits of steroid use, including increased } \\
\text { muscle mass, improved confidence and greater social status and peer } \\
\text { recognition were reported. } \\
\text { - Reasons for use: (1) a feeling that they were at a plateau in their training, (2) } \\
\text { frustration at watching others progress while they did not, and, (3) curiosity as to } \\
\text { their effects. } \\
\text { - } 50 \% \text { stated that their decision to try steroids was a difficult one, characterised by } \\
\text { feelings of guilt and/or compromised morals. } \\
\text { - } 8 \text { subjects commented that to be competitive at a high level in bodybuilding, } \\
\text { steroids and other drugs were a MUST. } \\
\text { - All acknowledged the possibility of psychological dependence. }\end{array}$ \\
\hline Pope et al (1999) & US & $\begin{array}{l}80 \text { Weightlifters } \\
\text { (43 AS users and } 37 \\
\text { non-users) } \\
\text { Mean age } \\
\text { Users - } 29.7 \text { years } \\
\text { Non-users - } 30.6 \text { years }\end{array}$ & $\begin{array}{l}\text { Qualitative Interviews and } \\
\text { Questionnaires } \\
\text { [Key themes: attitudes towards } \\
\text { physicians; level of trust in the } \\
\text { knowledge and advice provided by } \\
\text { physicians] }\end{array}$ & $\begin{array}{l}\text { - Subjects gave physicians high ratings on knowledge of general health and } \\
\text { conventional drugs but much lower ratings on knowledge of anabolic steroids. } \\
\text { - Steroid users rated physician knowledge significantly lower than non-users. } \\
\text { - As a source of knowledge on steroids, users scored physicians as no more } \\
\text { reliable than their friends, internet sites or the person who had sold them the } \\
\text { drugs. } \\
\text { - } 40 \% \text { of anabolic steroid users trusted information from their drug supplier at least } \\
\text { as much as they trusted information from their physician. } \\
\text { - Steroid users were also more inclined to disclose their use of steroids to male } \\
\text { friends, girlfriends or spouses than any physician they had seen. }\end{array}$ \\
\hline
\end{tabular}


Table 6. Descriptive analysis of studies examining the attitudes of bodybuilders, powerlifters and gym-users towards doping in sport.

\begin{tabular}{|c|c|c|c|c|}
\hline $\begin{array}{l}\text { First author } \\
\text { (year) }\end{array}$ & Country & Sample & Methods & Summary \\
\hline $\begin{array}{l}\text { Schwerin \& } \\
\text { Corcoran (1996) }\end{array}$ & US & $\begin{array}{l}47 \text { Male University } \\
\text { Bodybuilders } \\
\text { (20 steroid users and } 27 \\
\text { non-users) }\end{array}$ & $\begin{array}{l}\text { Beliefs About Steroids Scale, } \\
\text { BASS (Carney \& Corcoran, 1990). } \\
\text { [Key themes: beliefs about physical } \\
\text { and psychological effects of AS } \\
\text { use; Theory of Reasoned Action] }\end{array}$ & $\begin{array}{l}\text { - Significant differences were found between users and non-users on } 35 \text { out of } 40 \\
\text { questionnaire items. } \\
\text { - Steroid users expressed more positive beliefs about the physical and } \\
\text { psychological effects of anabolic steroid use. } \\
\text { - Amongst other reasons, users stated that they expected steroids to make them } \\
\text { feel more masculine ( } 3.84 \text { vs. } 2.85, P<.001) \text {, more confident ( } 3.79 \text { vs. } 2.44 \text {, } \\
P<.001) \text {, a better athlete ( } 3.74 \text { vs. } 2.48, P<.001) \text { and happier with themselves } \\
\text { (3.63 vs. } 1.85, P<.001) \text {. } \\
\text { - Hypothesise that behavioural beliefs are associated with behaviour. }\end{array}$ \\
\hline $\begin{array}{l}\text { Van Raalte et al } \\
\text { (1993) } \\
\text { Study replicates } \\
\text { and extends } \\
\text { research } \\
\text { conducted by } \\
\text { Schwerin and } \\
\text { Corcoran (1992) }\end{array}$ & US & $\begin{array}{l}\text { Mixed sample }(n=319) \\
\text { Exp } 1-22 \text { AS using } \\
\text { bodybuilders \& } \\
\text { powerlifters } \\
\text { Exp } 2-43 \text { non-using } \\
\text { athletes } \\
\text { Exp } 3-254 \\
\text { undergraduates }\end{array}$ & $\begin{array}{l}\text { Steroid Perception } \\
\text { Questionnaire (Scwerin\& } \\
\text { Corcoran, 1992) } \\
\text { [Key themes: AS using athletes - } \\
\text { perceptions of others; story } \\
\text { protagonist] }\end{array}$ & $\begin{array}{l}\text { - Steroid using athletes viewed the steroid user in the story no differently from the } \\
\text { diet conscious bodybuilder but more positively than the recreational cocaine } \\
\text { user. } \\
\text { - Non-steroid using athletes viewed the steroid using bodybuilder and the diet } \\
\text { conscious bodybuilder or athlete similarly. } \\
\text { - Undergraduate students viewed the steroid user more negatively than both the } \\
\text { diet conscious athlete and diet conscious bodybuilder. }\end{array}$ \\
\hline $\begin{array}{l}\text { Wagman et al } \\
\text { (1995) } \\
\text { (study also listed } \\
\text { in the elite } \\
\text { athletes section } \\
\text { for completeness) }\end{array}$ & US & $\begin{array}{l}15 \text { Elite US } \\
\text { Powerlifters } \\
10 \text { former or current } \\
\text { 'users' and } 5 \text { 'non-users' } \\
\text { Response rate }=60 \%\end{array}$ & $\begin{array}{l}\text { King Drugs in Sport } \\
\text { Questionnaire (King, 1991) } \\
\text { [Key themes: AS use; attitudes } \\
\text { towards AS use; regulation; } \\
\text { attitudes towards current } \\
\text { technology] }\end{array}$ & $\begin{array}{l}\text { - All participants indicated that their competitors at national / international level } \\
\text { were using AS. } \\
\text { - Two thirds of all respondents ( } 60 \% \text { users / } 80 \% \text { non-users) reported that current } \\
\text { doping controls were ineffective. } \\
\text { - Users were more likely than non-users to believe that 'I would not be hurting } \\
\text { anyone else if I decided to use AS' and that 'Taking AS is necessary if I am to be } \\
\text { competitive in my sport'. } \\
\text { - Non-users were more likely to agree that 'I do not need AS to help me become } \\
\text { the best athlete I can be'. } \\
\text { - All non-users compared to } 60 \% \text { of users indicated that they would not want to } \\
\text { compete if there were no doping controls. }\end{array}$ \\
\hline $\begin{array}{l}\text { Wright et al } \\
\text { (2001) }\end{array}$ & US & $\begin{array}{l}135 \text { Bodybuilders } \\
59 \text { steroid users } \\
\text { Response rate = } \\
\text { Unknown. } \\
89 \% \text { male }\end{array}$ & $\begin{array}{l}\text { Questionnaire } \\
\text { [Key themes: attitudes and motives } \\
\text { for steroid use; implications for } \\
\text { development of drug education] }\end{array}$ & $\begin{array}{l}\text { - Positive attitude to steroid use, negative aspects played down and mostly } \\
\text { attributed to ill-informed or ignorant practices. } \\
\text { - The majority of non-users viewed steroid use as cheating. } \\
\text { - Users and non-users generally agreed that steroids were used by many sports } \\
\text { people and were necessary for competing. } \\
\text { - Reasons for steroid use were often multiple, including to increased size/ } \\
\text { muscularity, to compete, cosmetic reasons, overcome plateau or out of curiosity. }\end{array}$ \\
\hline
\end{tabular}




\subsubsection{Discussion}

Attempts to document the prevalence of anabolic steroid use within the bodybuilding and weight lifting community have been the foci of research efforts. Accompanying this line of inquiry has been a limited number of the studies which have sought to examine this sub-cultures attitude towards anabolic steroids. However, use of and attitudes towards other performance enhancing drugs remains almost entirely unstudied. In terms of anabolic steroid research, investigators seeking to gain an understanding of patterns of use often draw from the bodybuilding population in view that use amongst this subgroup is believed to be higher than other groups of athletes. On balance, the evidence suggests that the majority of steroid users are knowledgeable and report that usage produces the desired physical increases in body mass and strength. Whilst most users indicate that they have experienced side-effects with steroid use, these are generally overridden by the belief that the benefits out-weigh the negative consequences. Those individuals, whose body shape most closely resembles the ideal, as determined within the bodybuilding subculture, are subject to high levels of peer recognition and acceptance, thus providing further reinforcement for the use of anabolic steroids. Hence, the recommendations by a number of researchers to consider the psychosocial pressures involved in drug abuse. In addition, based on the current literature, a general mistrust of the medical and/or scientific community appears to exist with regard to the effects of anabolic steroids. Most users prefer to consult fellow users, dope dealers or underground handbooks to physicians as sources of knowledge or advice.

Two key findings emerged from this literature that could pose significant challenges in developing doping education and prevention initiatives for this population. Firstly, there is widespread mistrust of the medical and scientific community, whose attempts to deny the efficacy of anabolic steroids appear to have compromised their integrity and authority in the minds of bodybuilders; many of whom have experienced first hand the effects of steroids in increasing muscle mass, enhancing performance and improving self-efficacy. Based on the research findings, anti-doping efforts presented by or affiliated with sections of the scientific community could be viewed with suspicion by this sub-group, and hence are unlikely to be effective in changing steroid related attitudes or behaviours. Secondly, it was apparent across a number of studies that bodybuilders and powerlifters, particularly those using steroids, consider existing prevention and testing 
strategies to be ineffective. It would appear that a number of methods can be employed to circumvent testing, such as 'cycling down' usage prior to testing or using masking agents and a number of studies reported that those surveyed had indicated that they had 'beaten the system'. Still, there were indications that a large proportion of the competing arm of this sub-group would prefer to compete under conditions where all performance enhancing drugs were prohibited and testing was $100 \%$ effective. This suggests that there is scope for anti-doping agencies to make an impact on drug use in this population.

An interesting insight into the morals and values of this subculture is provided by the qualitative research of Monaghan ${ }^{80}$, Olrich 86 and Olrich and Ewing ${ }^{87}$. Notably, it was reported that in addition to the more tangible physical gains associated with steroid use, those bodybuilders whose body shape most closely resembles that which is desired within that community, were subject to social reinforcement in the form of increased peer recognition and acceptance. For individuals that spend much of their spare time in the gym and as such develop strong relationships with fellow bodybuilders, the increased sense of belonging and respect that occur as a result of improved physique is likely to be a powerful motivator for continued steroid use. Indeed, a number of subjects expressed concerns regarding the reduction in body mass ('dropoff') and the resultant loss of social status associated with terminating steroid use. Accordingly, researchers should employ methodologies that provide insight into the psychosocial meanings of steroid use, especially when exploring prolonged use or dependency.

It was evident across a number of studies that many steroid users feel vilified by the perception that their drug use is comparable to that of other 'recreational' drug users or that their involvement in steroid use is irresponsible or deviant. There were indications that an unwritten code of conduct exists within the bodybuilding subculture, outlining boundaries within which doping could be practised safely, such that only those who 'abused' these conditions would suffer serious sideeffects. Many users describe their experiences of anabolic steroid use in a very positive manner and justify it as a means of achieving socially acceptable competitive or physical goals. These points combined indicate that reducing steroid use in this population is an extremely challenging and complex proposition. 
Evidence in this field is strengthened by the insights and depth of understanding provided by qualitative work, which has often been lacking in doping research. The decision of one or two researchers to focus upon this community means that they are probably in a well placed position to make recommendations on the content and strategy framework for anti-doping initiatives targeted at this group. However, use of performance enhancing drugs, other than anabolic steroids, remains almost entirely unstudied in bodybuilders and powerlifters and should be addressed by researchers in the future. Given that the majority of research has been conducted in the United States, researchers must be cautious in generalising findings to other countries where bodybuilding cultures and ethics may differ. In addition, it may be inappropriate to generalise findings from this review to other groups of athletes, in view that motivating factors for drug use are likely to be disparate. 


\section{$4 \quad$ ATTITUDES TOWARDS DOPING}

\subsection{Detailed Analysis - Medical Professionals}

\subsubsection{Summary}

Despite the pivotal role that medical professionals play in the health and well-being of athletes, particularly elite athletes, few researchers have sought to understand the doping-related knowledge and attitudes of this sub-group. Whilst it is unwise to generalise findings based upon such a limited number of investigations, it is encouraging to note that the majority of medical professionals surveyed express a negative attitude towards prescription of performance enhancing drugs for non-medical purposes. However, a small proportion of survey respondents admitted to prescribing doping drugs for non-medical purposes or directing patients to another general practitioner (GP) who would be prepared to do so. Trainee doctors in Greece also supported this facilitating view. Further, initial results suggest that GPs and pharmacists require significantly more education on the subject of doping and this may serve to minimise the inadvertent supply of doping agents. A key challenge for anti-doping agencies will be to identify and take steps to prevent the actions of medical professionals who knowingly supply both professional and recreational athletes with doping agents. Again, the research presented hereafter is low in the research hierarchy being cross-sectional in nature, utilising non-validated questionnaires and employing basic statistical analysis. Still, the information that follows is a detailed analysis of the main findings of peer-reviewed articles that have gone beyond merely reporting prevalence statistics by offering information on medical professionals' knowledge and attitudes towards doping and drug testing systems.

\subsubsection{Background}

Eight peer-reviewed studies were identified that explored knowledge and attitudes towards performance enhancing drugs amongst the medical profession. Two studies were conducted in France ${ }^{64,65}$, two in the United Kingdom ${ }^{46,95}$ and one each in Australia ${ }^{51}$, the United States ${ }^{95}$, Italy 103 and Greece ${ }^{91}$. Three studies focused specifically upon anabolic steroids 51,95 and five addressed doping in a more general sense $46,64,65,91,103$. A summary of key findings from those studies is shown in Table 7 and a study annotation is provided in Appendix A. 


\subsubsection{Sample}

Five studies gathered data from GPs $46,51,64,95$, one study surveyed retail pharmacists, one examined young doctors and trainees ${ }^{91}$ and the Italian survey examined doctors concomitantly with athletes, coaches and managers ${ }^{103}$. Sample size ranged from 10395 to $1231{ }^{103}$. However, the Scarpino et al. study was a mixed sample, comprising 102 doctors only. Therefore, Salva and Bacon 102 represented the largest sample of doctors ( $n=517)$. Including the full sample of Scarpino et al., sample size totalled 2582 across all studies, with a mean of 323 subjects per study. This mean figure falls to 193 medical professionals per study $(n=1545)$ if only the sample of doctors from the Scarpino et al. study is included in the analysis. Two studies did not provide details of subjects' age or gender 46,95 and information on subjects ethnicity was not detailed in any paper. Males comprised $69 \%{ }^{51}, 75 \% 64$ and $84 \%{ }^{95}$ of the total sample for three studies conducted with GPs, $83 \%$ for the sample conducted with trainee doctors, whilst distribution by gender was more even ( $52 \%$ male) for the only paper that examined retail pharmacists. The Italian survey did not describe the gender distribution ${ }^{103}$. In the studies that provided demographic details, subjects mean age was $28 \pm 3$ years in the trainee doctors study and between 43 and 46 51,64,65, 95 in the remaining studies. Two studies provide detail on the respondents medical experience, with subjects reporting 15 years ${ }^{95}$ and 16 years ${ }^{64}$ of experience as a registered physician, respectively. Pharmacists reported 15 years on the pharmaceutical register 64 .

\subsubsection{Methods}

All papers report on data gathered by cross-sectional survey. Four studies utilised a postal questionnaire 46, 51, 102, 103 and two used a scripted telephone interview based upon a questionnaire 64,65 . Perry et al ${ }^{95}$ and Panagiotis et al. ${ }^{91}$ also administered a questionnaire to gather data, though it is unclear how they were administered. Survey response rate varied from $39 \% 46$ to $100 \% 91$. Of the six papers that utilised questionnaires $46,51,91,95,102,103$ all were developed for the specific study at hand by the investigators and were not validated. Although Laure and colleagues 64,65 utilised a questionnaire developed in previous studies by the lead author, validity and reliability statistics are not reported. Moreover, questionnaire content and format, in terms of the number of items included and the use of open / closed answer questions is not presented in any of the articles reviewed. 
As highlighted, only two studies 64,65 employed the same questionnaire, therefore a detailed synthesis of the topics explored across all studies is not possible. However, broad themes of investigation, consistent across the body of research, can be summarised. Researchers generally sought to examine the degree of contact GPs / pharmacists have with either anabolic steroid 51,95, 102 or doping drug users 64,65, 103. Subjects knowledge of doping issues, procedures and sources of information on doping 46,51,64,65, 91, 103 were explored. The legal status of specific substances 46, 91 and willingness to prescribe steroids for non-medical purposes 46, 51, 64, 65, 91 were also examined. GPs and pharmacists were questioned regarding their opinions toward preferred methods of doping education ${ }^{51}$, their role in preventing doping and the effectiveness of current prevention efforts $51,64,65$. Furthermore, one study explored the education of trainee doctors in Greek medical schools, with specific emphasis on doping ${ }^{91}$.

\subsubsection{Findings: Contact with Doping}

The majority of studies indicated that survey respondents had received enquiries for doping substances or consulted with known users. For example, Salva and Bacon ${ }^{102}$ report that $55 \%$ of respondents had been asked about steroids or consulted with a possible user in the previous five years. They also noted that for patients aged $13-17,26 \%$ of enquiries regarding anabolic steroids were made by parents ${ }^{102}$. Laure et al 64 indicated that $11 \%$ of GPs have been directly confronted with a request for the prescription of doping agents. Greenway and Greenway ${ }^{46}$ stated that $18 \%$ of respondents have prescribed or been asked to prescribe anabolic steroids for performance enhancement or body image purposes. Laure et al 64 reported that $25 \%$ of pharmacists have been in a situation where a prescription presented to them appeared suspicious. In addition, $6 \%$ of the pharmacists stated that they have received financial or other such like proposals to supply doping agents to groups of athletes (e.g., a club) ${ }^{64}$.

\subsubsection{Findings: Knowledge of doping}

Six studies assessed knowledge of doping related issues $46,64,65,91,103$. Laure et al 64 report that $77 \%$ of GPs considered themselves poorly trained to take action in preventing doping. Gupta and Towler ${ }^{51}$ state that only $54 \%$ of GPs felt they had sufficient knowledge to advise patients about anabolic steroids and Panagiotis et al. ${ }^{91}$ concluded that trainee GPs and internal medical doctors doping in sport knowledge was also poor. However, it must be acknowledged that this study only 
surveyed trainee doctors from a single, local hospital in Greece. Poor doping knowledge was also identified in pharmacists. According to Laure et al ${ }^{64} 74 \%$ of pharmacists felt themselves to be poorly trained in the issue of doping in sport.

Importantly, when knowledge was assessed through objective methods such assertions were corroborated. Of the eight classes of prohibited substances at the time of investigation, on average, pharmacists could name only 1.7 agents on the banned list ${ }^{64}$. In a similar study, Laure et al 64 report that GPs named, on average, 2.6 substances that appeared on the International Olympic Committees (IOC) list of banned agents, which had expanded to include thirteen classes of prohibited drugs at the time of study. Approximately $18 \%$ of pharmacists and $27 \%$ of GPs were not aware that the Vidal dictionary (equivalent of the Physician's Desk Reference or the Martindale) contained a list of prohibited substances in sport 64,65 . Only $35 \%$ of GPs were aware that the British National Formulary contained a list of prohibited substances, with $23 \%$ incorrectly stating that it does not contain such a list and 66\% responding "don't know" 46 . Only 25\% of trainee doctors indicated that they had heard of the IOC/WADA list of banned substances ${ }^{91}$. Between $20-30 \%$ of respondents answered incorrectly or responded "don't know" when asked to indicate the legal status of a number of drugs, including salbutamol, oral steroids, inhaled corticosteroids and dihydrocodeine ${ }^{46}$ and in one study although 100\% of respondents recognised that anabolic-androgenic steroids were used as performance enhancing aids, only $6 \%$ referred to blood doping as a doping method ${ }^{91}$. According to Gupta and Towler ${ }^{51}, 46 \%$ of GPs incorrectly stated that most anabolic steroid users were competitive athletes, whilst only $13 \%$ correctly indicated that psychological dependence is a common side effect of steroid use. Interestingly, although the trainee doctors acknowledge the ergogenic nature of anabolic steroids, only $54 \%$ reported that they were aware of the effect of use on the muscle and fewer respondents (35\%) referred to the adverse impacts on the athlete's health ${ }^{91}$.

\subsubsection{Findings: Attitudes towards doping}

All studies examined subjects' attitudes or beliefs regarding doping agents in general $46,64,65,91$, 103 or anabolic steroids in particular 51,95,102. Gupta and Towler 51 reported that in a hypothetical situation $6 \%$ of GPs were willing to prescribe steroids for non-medical purposes and $2 \%$ admitted to prescribing anabolic steroids to assist in bodybuilding. Seventy-nine percent of pharmacists 
and $75 \%$ of GPs indicated that doctors were a source of doping agents, though both believed that other athletic team members were a more likely supply for such drugs 64,65 . Further, Gupta and Towler ${ }^{51}$ stated that $21 \%$ of respondents knew of at least one GP that would be willing to prescribe anabolic steroids for non-medical purposes.

Approximately $88 \%$ of pharmacists and GPs indicated that doping is a public health problem, but GPs were more likely to believe that doping is a form of drug addiction (80\% vs. $69 \%) 64,65$. Gupta and Towler 51 report that 40\% of GPs would be willing to monitor and advise a known anabolic steroid user and Perry et al ${ }^{95}$ report that $72 \%$ of GPs state they would extend harm minimisation procedures to such users. These findings are in contrast to an unpublished study by the Netherlands Centre for Doping Affairs ${ }^{83}$. They surveyed 503 GPs and found that a large majority of GPs are unwilling to monitor an athlete during doping use. This study was not included in the main analysis because it has not been subject to peer-review and therefore did not meet our inclusion criteria. However, given the large sample size, the findings are noteworthy and highlight the importance of dissemination to the wider scientific and practitioner community. Over $15 \%$ of trainee doctors in Greece believed that a "health physician must be allowed to prescribe anabolic steroids or other ergogenic aid substances, even without medical therapeutic indication, if athletes ask for them" ${ }^{91}($ p.3).

On the subject of doping prevention, $82 \%$ of GPs ${ }^{64}, 73 \%$ of pharmacists ${ }^{64}$ and $48 \%$ of trainee doctors ${ }^{91}$ consider that current methods of prevention are ineffective. The vast majority of surveyed GPs (89\%) ${ }^{64}$ and pharmacists (91\%) ${ }^{64}$ believe that they have a role to play in preventing doping, but feel inadequately trained to do so. Inadequate training was also identified in the study by Panagiotis et al ${ }^{91}$. Across the studies, it was clear that members of the medical profession want more information about doping 51,103 and one study indicated that the preferred format for educational materials was a pamphlet or fact sheet ${ }^{51}$. However, caution must be asserted because one study is unlikely to be representative of the doping education needs of the medical profession. Finally, this perceived lack of knowledge is exacerbated by the fact that one study demonstrated that sports newspapers were the main source of knowledge about doping substances, methods and the doping control process, rather than the practitioners medical education 91. 
Table 7. Descriptive analysis of studies examining the attitudes of the medical profession towards doping in sport.

\begin{tabular}{|c|c|c|c|c|}
\hline $\begin{array}{c}\text { First author } \\
\text { (year) }\end{array}$ & Country & Sample & Methods & Summary \\
\hline $\begin{array}{l}\text { Gupta and } \\
\text { Towler (1997) }\end{array}$ & Australia & $\begin{array}{l}143 \text { General } \\
\text { Practitioners } \\
69 \% \text { male } \\
\text { Median age }=46 \\
\text { Response Rate }=87 \%\end{array}$ & $\begin{array}{l}\text { Questionnaire } \\
\text { [Key themes: contact with (known } \\
\text { and/or suspected) users, non- } \\
\text { medical prescription of AS, } \\
\text { knowledge and sources of steroid } \\
\text { information] }\end{array}$ & $\begin{array}{l}\text { - } 55 \% \text { stated they had seen at least one patient in the last year that had used } \\
\text { steroids for non-medical purposes. } \\
\text { - } 21 \% \text { reported knowing another GP who would prescribe steroids for non } \\
\text { medical purposes. } \\
\text { - } 40 \% \text { of respondents indicated they would advise a known user on side } \\
\text { effects and safe injecting methods (responding to a fictional scenario). } \\
\text { - } 51 \% \text { believed they had insufficient knowledge to advise patients on doping. } \\
\text { - } 77 \% \text { wanted more information on steroids }\end{array}$ \\
\hline $\begin{array}{l}\text { Greenway and } \\
\text { Greenway } \\
\text { (1997) }\end{array}$ & UK & $\begin{array}{l}157 \text { General } \\
\text { Practitioners } \\
\text { Response Rate }=39.2 \%\end{array}$ & $\begin{array}{l}\text { Questionnaire } \\
\text { [Key themes: sources of doping } \\
\text { information, knowledge of drugs, } \\
\text { non-medical prescription of AS] }\end{array}$ & $\begin{array}{l}\text { - } 35 \% \text { correctly stated that information on banned substances could be found } \\
\text { in the British National Formulary ( } 66 \% \text { responded "don't know"). } \\
\text { - } 18 \% \text { indicated that they had either prescribed or been asked to prescribe } \\
\text { anabolic steroids for performance enhancement or body image purposes. } \\
\text { - } 12 \% \text { of GPs incorrectly stated that doctors are permitted to prescribe } \\
\text { anabolic steroids for non-medical purposes. }\end{array}$ \\
\hline $\begin{array}{l}\text { Laure et al } \\
(2000)\end{array}$ & France & $\begin{array}{l}198 \text { Retail Pharmacists } \\
52 \% \text { male } \\
\text { Mean age }=43 \\
\text { Response Rate }=66 \%\end{array}$ & $\begin{array}{l}\text { Telephone Interview } \\
\text { [Key themes: knowledge of doping } \\
\text { agents, contact with doping users, } \\
\text { training in and commitment to } \\
\text { doping prevention] }\end{array}$ & $\begin{array}{l}\text { - } 25 \% \text { had been confronted by a request for information on doping agents in } \\
\text { the previous } 12 \text { months. } \\
\text { - } 73 \% \text { believed current prevention methods were ineffective. } \\
\text { - Respondents indicated that prevention efforts should be aimed at children } \\
\text { followed by amateur athletes and then professional athletes. } \\
\text { - } 88 \% \text { indicated that they considered doping to be a public health problem } \\
\text { and } 69 \% \text { that doping is a form of drug addiction. } \\
\text { - } 91 \% \text { of pharmacists believed that they have a role to play in doping } \\
\text { prevention, but } 74 \% \text { considered themselves poorly trained to do so. }\end{array}$ \\
\hline $\begin{array}{l}\text { Laure et al } \\
\text { (2003) }\end{array}$ & France & $\begin{array}{l}202 \text { General } \\
\text { Practitioners } \\
75.5 \% \text { male } \\
\text { Mean age }=45 \\
\text { Response Rate }=50.5 \% \mathrm{n}\end{array}$ & $\begin{array}{l}\text { Telephone Interview } \\
\text { [Key themes: knowledge of doping } \\
\text { agents, contact with doping users, } \\
\text { training in and commitment to } \\
\text { doping prevention] }\end{array}$ & $\begin{array}{l}\text { - } 37 \% \text { had been confronted by a request for information and } 11 \% \text { a request } \\
\text { for prescription of doping agents in the last } 12 \text { months. } \\
\text { - } 82.5 \% \text { stated that current methods of preventing doping in sport were } \\
\text { ineffective. } \\
\text { - } 89 \% \text { of GPs believed that they had a role to play in preventing doping, but } \\
77 \% \text { considered themselves poorly on this matter. } \\
\text { - GPs indicated that doping prevention efforts were necessary due to health } \\
\text { risks associated with drug use ( } 81 \%) \text { and sports ethics ( } 12 \%) \\
\text { - GPs indicated that prevention efforts should be aimed at children and } \\
\text { adolescents followed by professional athletes and then amateur athletes. }\end{array}$ \\
\hline
\end{tabular}


Table 7. Descriptive analysis of studies examining the attitudes of the medical profession towards doping in sport.

\begin{tabular}{|c|c|c|c|c|}
\hline $\begin{array}{l}\text { First author } \\
\text { (year) }\end{array}$ & Country & Sample & Methods & Summary \\
\hline $\begin{array}{l}\text { Panagiotis et al. } \\
\text { (2006) }\end{array}$ & Greece & $\begin{array}{l}123 \text { Trainee Doctors } \\
83 \% \text { male } \\
\text { Mean age }=28 \\
\text { Response Rate }=100 \%\end{array}$ & $\begin{array}{l}\text { Questionnaire } \\
\text { [Key themes: knowledge of doping } \\
\text { agents and their effects, sources of } \\
\text { knowledge, attitudes towards } \\
\text { prevention; sports medicine } \\
\text { training] }\end{array}$ & $\begin{array}{l}\text { - Only } 25 \% \text { of respondents had heard of the WADA/IOC banned lists and only } \\
5.7 \% \text { possessed knowledge of the laboratory control procedures. } \\
\text { - } 99 \% \text { declared that newspapers were their main source of knowledge relating } \\
\text { to doping, rather than their medical studies. } \\
\text { - } 87 \% \text { felt under-trained in practicing sports medicine. } \\
\text { - Nearly half of those surveyed ( } 48 \% \text { ) considered the current methods of } \\
\text { preventing doping in sport as ineffective }\end{array}$ \\
\hline $\begin{array}{l}\text { Perry et al } \\
\text { (1994) }\end{array}$ & UK & $\begin{array}{l}103 \text { General } \\
\text { Practitioners } \\
84 \% \text { male } \\
\text { Mean age }=43 \\
\text { Response Rate }=85.8 \%\end{array}$ & $\begin{array}{l}\text { Questionnaire } \\
\text { [Key Themes: contact with anabolic } \\
\text { steroid users, medical tests offered } \\
\text { to users, willingness to provide } \\
\text { harm minimisation advice, } \\
\text { awareness and confidence in } \\
\text { support services] }\end{array}$ & $\begin{array}{l}\text { - } 52 \% \text { had knowingly consulted for known steroid users. } \\
\text { - } 66 \% \text { perceived that there is a steroid problem in West Glamorgan. } \\
\text { - } 72 \% \text { indicated they would extend harm minimisation procedures to users. } \\
\text { - Only } 34 \% \text { of GPs expressed confidence in counselling services available to } \\
\text { steroid users. }\end{array}$ \\
\hline $\begin{array}{l}\text { Salva and } \\
\text { Bacon (1991) }\end{array}$ & US & $\begin{array}{l}517 \text { General } \\
\text { Practitioners } \\
\text { Response Rate }=40 \%\end{array}$ & $\begin{array}{l}\text { Questionnaire } \\
\text { [Key themes: frequency and nature } \\
\text { of enquiries about steroids, contact } \\
\text { with known steroid users] }\end{array}$ & $\begin{array}{l}\text { - } 50 \% \text { reported at least one enquiry about anabolic steroids in the preceding } 5 \\
\text { years. } \\
\text { - The majority of enquiries for young adults and adults were in relation to } \\
\text { bodybuilding activities. Enquiries were most frequently in relation to sports } \\
\text { activities (primarily American football). } \\
\text { - } 26 \% \text { of teenager inquiries were made by parents. }\end{array}$ \\
\hline $\begin{array}{l}\text { Scarpino et al } \\
\text { (1990) }\end{array}$ & Italy & $\begin{array}{l}102 \text { doctors, } 1015 \text { Italian } \\
\text { athletes and } 92 \text { coaches \& } \\
\text { managers }(n=1231) \\
\text { Males }-67 \%\end{array}$ & $\begin{array}{l}\text { Questionnaire and interview } \\
\text { [Key themes: knowledge of the } \\
\text { effects of drug use on athletic } \\
\text { performance; prevalence of doping } \\
\text { practices; availability of doping } \\
\text { agents; reasons for drug use] }\end{array}$ & $\begin{array}{l}\text { - Study did not clearly differentiate between doctors, coaches and managers } \\
\text { when discussing the findings. } \\
\text { - } 21 \% \text { of doctors indicated that athletic performance could be enhanced by } \\
\text { use of drugs and other doping practices. } \\
\text { - More than } 20 \% \text { of technicians (doctors, coaches and managers) stated that } \\
\text { anabolic steroids were being used frequently at national or international } \\
\text { level. } \\
\text { - A greater number of technicians indicated that doping was potentially } \\
\text { harmful than stated it was efficacious in improving performance. } \\
\text { - Over } 60 \% \text { of technicians reported that the } 7 \text { substances examined were } \\
\text { dangerous }\end{array}$ \\
\hline
\end{tabular}




\subsubsection{Discussion}

The strength of the literature in relation to doping and the medical population is weak. Few studies have been conducted and those that have can be categorised as level III research, which is one of the lowest categories in the hierarchy of evidence. Research to date has drawn upon data gathered by non-validated questionnaires, administered either by post or used as a template for telephone interviews. Thus, the reliability and validity of the findings may be compromised and also subject to self-presentation bias. A response rate of less than 50\%, reported in three studies reviewed here, may compromise study findings due to the inherent response bias. In addition, all studies were retrospective in nature, wherein the validity of findings may be questioned, due to the reliance upon subjects' accurate recall of past events. It should also be noted that the quality of research in this field is occasionally compromised by a failure to gather sufficient data, report it accurately and analyse or discuss the findings in enough detail. However, a brief discussion is drawn from the limited number of studies that were identified in the search in the hope that it will stimulate future research on this important sub-group.

Since 1990, a handful of researchers have sought to understand the doping-related knowledge and attitudes of GPs, trainees and pharmacists. Early findings indicate that these professionals are confronted with the doping issue in their work, either in the prescription of performance enhancing drugs or in providing information for users and potential users. With this is mind, it is essential that all parties receive sufficient training and have a good understanding of this area. One of the key themes to emerge from the research in this field is that GPs, trainees and pharmacists acknowledge that they have a role to play in preventing doping but they perceive that they lack the knowledge to take effective action. Based on the limited evidence base, it is unclear if this lack of knowledge can be generalised to the medical profession as a whole. Furthermore, it is unlikely that educational needs will be identical between nations, thus it may not be appropriate to generalise findings of studies conducted in different countries. Accordingly, further research is required to establish the needs of medical professionals in order to obtain an evidence base from which to design appropriate educational strategies for this target group.

Perhaps the most significant finding to emerge from this review is that whilst the majority of GPS view doping negatively and express a commitment towards its prevention, a small number of 
GPs, either directly or indirectly, support the use of performance enhancing drugs in sport. A small proportion of GPs admitted to prescribing doping drugs for non-medical purposes or directing patients to another GP who would be prepared to do so 46,51 and trainees also supported this facilitating view ${ }^{91}$. It may also be the case that where GPs have lacked appropriate knowledge, they have prescribed doping agents (specifically anabolic steroids) for the purposes of performance enhancement, unaware that this is against the law ${ }^{46}$. Improved education for GPs will serve to minimise the inadvertent supply of doping agents in this manner. The key challenge for anti-doping agencies, however, will be to identify and take steps to prevent the actions of GPs who knowingly supply both professional and recreational athletes with doping agents. 


\section{$4 \quad$ ATTITUDES TOWARDS DOPING}

\subsection{Detailed Analysis - Coaches and support staff}

\subsubsection{Summary}

Over a decade ago, Dubin 30 emphasised the importance of coaches as potential agents in the prevention of drug use amongst athletes. Despite this assertion and the central role that coaches can play in an athlete's life, few studies have examined the doping-related knowledge and attitudes of coaches and support staff. Whilst it is unwise to generalise findings based upon such a limited number of investigations, the majority of coaches and other athletic support staff surveyed report a negative attitude towards doping, both in regard to its ethical position and its impact upon athlete health. However, across the spectrum of athletic performance, this group is faced with doping related issues in their work. Further, the majority acknowledged that they were in need of additional education and support to enable them to take appropriate action. This is consistent with the other sections on attitudes and knowledge. Again, the studies presented hereafter are low in the research hierarchy being cross-sectional in nature, utilising non-validated questionnaires and employing basic statistical analysis. Still, the information that follows is a detailed analysis of the main findings of peer-reviewed articles that have focused upon coaches and support staff.

\subsubsection{Background}

Seven studies exploring the knowledge and attitudes of coaches, athletic directors and athlete support staff (managers) were identified. Three were conducted in the United States 110, 112, 116 with the remaining undertaken in Norway ${ }^{34}$, Italy ${ }^{103}$, France 68 and Hong Kong ${ }^{37}$. Two studies focused primarily upon athletic trainers attitudes towards drug testing and education in a college/university setting 112,116 . One study examined the observations-perceptions of athletic directors and coaches in relation to drug use amongst athletes and non-athletes ${ }^{110}$. Knowledge, attitude and behavioural intentions of a sample of community coaches attending a coach education class was also considered and the remaining studies explored knowledge and attitudes towards doping in a more general sense $34,68,103$. A brief descriptive analysis of each study can be found in Table 8 and a detailed annotation in Appendix A. 


\subsubsection{Sample}

Two studies focused entirely on coaches alone 37,68 and one study surveyed coaches alongside managers and doctors ${ }^{103}$. The remaining studies focused on the following support staff; community sports leaders and instructors ${ }^{34}$, athletic trainers ${ }^{116}$, head athletic trainers ${ }^{112}$ and athletic directors 110 . Sample size was fairly consistent, ranging from 10034 to 353112 . However, the Scarpino et al. ${ }^{103}$ study was a mixed sample, comprising 1231 participants, but only 114 participants were coaches or managers. Including the full sample of Scarpino et al., sample size totalled 2231 across all studies, with a mean of 372 subjects per study. This mean figure falls to 139 coaches/support staff per study (total $n=1114$ ) if only the sample of coaches and managers from the Scarpino et al. study are taken into account. In the five studies that reported subjects' gender, males dominated and comprised between $68-96 \%$ of the sample $37,68,103,110,116$. No study indicated respondents ethnicity and only Laure et al 68 and Fung \& Yuan ${ }^{37}$ reported subjects age, with a mean of 29 years and 30 years, respectively.

\subsubsection{Methods}

All studies utilised a cross-sectional survey design, with three researchers gathering data using a postal questionnaire 68,110,116. Shirazi and Tricker 112 employed an internet based questionnaire, Fjeldheim ${ }^{34}$ administered a questionnaire in person, and Scarpino et al ${ }^{103}$ conducted semistructured interviews. Fung and Juan ${ }^{37}$ did not report how the questionnaire was administered. Of the six studies that employed a questionnaire, five were devised by the investigators specifically for the study at hand 34,37,110,112,116 and one was based upon an instrument developed in previous research ${ }^{68}$. Only Shirazi and Tricker 112 and Fung and Yuan ${ }^{37}$ report the steps taken to ensure the validity and reliability of their questionnaire. Fung and Yuan 37 consulted doping and drug use experts and Shirazi and Tricker ${ }^{112}$ undertook a slightly more robust testing procedure via questionnaire assessment by a panel of experts, followed by pilot testing.

Researchers examined a disparate range of research questions. For example, awareness of different doping agents, knowledge of their possible effects (positive and negative) ${ }^{34,103}$ and availability and contact with such substances on a daily basis $34,68,103$ were considered. Fung and Yuan ${ }^{37}$ applied the tenets of a social-cognitive theory to examine Hong Kong community 
coaches' performance enhancement knowledge, attitudes and behavioural intention towards doping. Further, Fjeldheim ${ }^{34}$ examined subjects views on the ethics of doping, in terms of whether it constitutes cheating, appropriate punishments for offenders and attitudes towards antidoping guidelines and Shields ${ }^{110}$ explored athletic directors opinions regarding prevalence of drug use amongst athletes and non-athletes. Finally, Starkey et al 116 and Shirazi and Tricker 112 assessed athletic trainers attitude towards drug testing in general and as it was practised at their particular institution.

Due to the diversity of the sample composition and the range of research questions addressed in data collection, direct comparison of research findings is not possible or conducive. Therefore, results are summarised under broad themes of interest, examined across the body of research.

\subsubsection{Findings: Contact with doping}

Subjects employed in a variety of settings (college/university, community) and working with athletes at all levels of performance (community, college/university, professional) indicated that they were faced with doping related issues in their work. Seventeen percent of coaches reported that they had been directly confronted with a request for information on doping in the previous 12 months 68 , whilst $78 \%$ of athletic directors were personally aware of athletes at their institution using drugs ${ }^{110}$. With regard to the perceived prevalence of doping, $81 \%$ of sports instructors / leaders disagreed to some degree with the statement that there is no extensive use of doping in elite sports ${ }^{34}$. Scarpino et al 103 report that 6 $20 \%$ of sports coaches, doctors or managers believe that amphetamines and/or anabolic steroids are being used frequently at national or international level. On the subject of availability or sources of doping agents, $11 \%$ of sports leaders / instructors were aware of another leader or instructor that has distributed doping drugs ${ }^{34}$. Laure et al 68 and Fjeldheim ${ }^{34}$ report that athletes are most likely to obtain doping agents from team members, another coach / leader, physician or pharmacist. Between 4-6\% of coaches and/or sports instructors / leaders reported personal use of doping drugs within the previous 12 months 34,68 .

\subsubsection{Findings: Beliefs regarding the effects of doping}

Three studies 34, 68, 103 examined attitudes regarding the effects of doping, either on athletic performance or physical and psychological health. There was general agreement that doping 
substances could lead to improved performance but were also likely to result in negative health consequences. For example, Scarpino et al 103 report that $30 \%$ of coaches and managers believed that athletic performance could be improved by drugs or other doping practices. Seventy percent of coaches believed that most records have been broken due to doping and $30 \%$ thought that an athlete who declines doping has little chance of success ${ }^{68}$. A similar finding emerged from a sample of community coaches in Hong Kong, with only $70 \%$ not agreeing that refusing to take performance enhancing drugs means refraining from being an elite athlete. However, in this study, just over half of the coaches sampled agreed that most achievement records in sport are related to doping and a little over $20 \%$ of the sample highly agreed that scientific research should develop drugs that can pass tests of doping control. On the subject of health, Fjeldheim ${ }^{34}$ reported that $94 \%$ of sports leaders I instructors indicated that doping should be outlawed due to its negative effects on health. Similarly, only $10 \%$ of coaches stated that doping may be used without hazard to health even when supervised by a physician 68 . Between $61-95 \%$ of sports coaches, managers and doctors indicated that doping agents, such as amphetamines, diuretics, beta-blockers and anabolic steroids, posed a threat to health, a noticeably higher proportion than believed they were efficacious in improving performance 103.

\subsubsection{Findings: Attitudes toward doping prevention}

It was generally agreed that athletic support staff have a role to play in doping prevention. One hundred percent of sports instructors / leaders surveyed by Fjeldheim ${ }^{34}$ and $98 \%$ of coaches assessed by Laure et al 68 reported that they have a role to play in preventing doping. It is interesting to note that opinion regarding the effectiveness of current prevention efforts varied between studies. Ninety three percent of sports instructors / leaders agreed that the Norwegian Sports Association's policy is effective in reducing doping [15], whilst $80 \%$ of coaches from France reported that current methods of preventing doping are ineffective ${ }^{68}$. It is unclear whether this disparity in findings reflects the contrasting status of doping prevention efforts between nations or the opposed views of coaches versus community leaders and instructors. Unfortunately, not all studies, including the investigation of community coaches in Hong Kong, examined attitudes towards doping prevention. Still, those that did agreed that further work is required to prevent doping. Over two thirds of sports technicians (coaches, doctors, managers) highlighted a need for more frequent and efficacious control of the sports 
environment ${ }^{103}$ and Laure et al 68 report that $96 \%$ of coaches stated a need for preventive actions with $73 \%$ requesting specific training on the subject.

\subsubsection{Findings: Attitudes towards testing and education}

Three studies surveyed the opinion of college or university athletic trainers or directors on issues of drug use ${ }^{110}$, testing and education 111,116 . Starkey et al ${ }^{116}$ state that $62 \%$ of athletic trainers expressed concern that drug testing placed them in the dual role of police and counsellor, but that on the whole this did not compromise their relationship with the athletes. Trainers were more inclined towards acting as a resource for the organisation of a testing programme, rather than serving as administrators of the sampling process ${ }^{116}$. The majority of athletic trainers indicated that student athletes should be provided with drug education at least once a year, that they would support student rehabilitation and submit to testing themselves in order to keep their job 116.

Shirazi and Tricker ${ }^{112}$ compared the perceptions of head athletic trainers (HATs) with regard to the composition of current drug testing practices and areas of improvement. HATs from National Collegiate Athletic Association (NCAA) division 1 institutions were significantly more likely to indicate that their drug education programmes emphasised improving students knowledge on drug use, focused upon students attitudes and attempted to change behaviour than HATs from divisions 2 and 3. HATs from all NCAA division indicated that alcohol and drug education programmes needed to be scheduled closer to social or athletic events when the possibility of drug use amongst athletes was increased. Disparities between actual and desired components of drug education were highlighted in relation to the need to provide more information of nutritional supplements and their risks, and in attempting to change students' drug related attitudes and behaviour. HATs from all institutions indicated that barriers to the development and evaluation of alcohol and drug education programmes were inadequate guidelines on policy development, financial constraints and a failure to acknowledge the time limitations that exist in practice. 
Table 8. Descriptive analysis of studies examining the attitudes of coaches and support staff towards doping in sport.

\begin{tabular}{|c|c|c|c|c|}
\hline $\begin{array}{l}\text { First author } \\
\text { (year) }\end{array}$ & Country & Sample & Methods & Summary \\
\hline Fjeldheim (1992) & Norway & $\begin{array}{l}100 \text { sports instructors } \\
\text { and sports leaders }\end{array}$ & $\begin{array}{l}\text { Questionnaire } \\
\text { [Key themes: knowledge of and } \\
\text { attitudes towards doping in sport] }\end{array}$ & $\begin{array}{l}\text { - } 98 \% \text { stated that it is cheating to use doping practices in sport. } \\
\text { - } 94 \% \text { stated doping should not be allowed due to negative side effects. } \\
\text { - All sports leaders and instructors believed they had a role to play in } \\
\text { preventing doping. } \\
\text { - } 10 \% \text { believed that doping controls in Norway were too strict, whilst } \\
37 \% \text { indicated that they thought it was unfair that Norwegian athletes were } \\
\text { subject to stricter controls than those from other nations. } \\
\text { - Knowledge of doping issues was lacking. } 25 \% \text { were unable to mention } \\
\text { a single method of doping in sport and } 46 \% \text { were not aware of laws relating } \\
\text { to being an accessory to use of anabolic steroids. }\end{array}$ \\
\hline $\begin{array}{l}\text { Fung \& Juan } \\
\text { (2006) }\end{array}$ & Hong Kong & $\begin{array}{l}114 \text { Community Coaches } \\
82 \% \text { male } \\
\text { Mean age }-29.3(\mathrm{SD} \pm \\
\text { 8.1) }\end{array}$ & $\begin{array}{l}\text { Questionnaire (61-items) } \\
\text { [Key themes: community coaches; } \\
\text { actual knowledge \& perceived } \\
\text { knowledge of doping; attitudes } \\
\text { towards doping; behavioural } \\
\text { intention; Theory of Planned } \\
\text { Behaviour] }\end{array}$ & $\begin{array}{l}\text { - } 70 \% \text { disagreed "refusal to take performance drugs equals to refraining from } \\
\text { being an elite athlete". } \\
\text { - } 63 \% \text { disagreed or highly disagreed that they would find ways to assist } \\
\text { friends or relatives (significant others) to get hold of banned substances. } \\
\text { - } 20 \% \text { of the sample highly agreed that scientific research should develop } \\
\text { drugs that can pass tests of doping control. } \\
\text { - The relationship between subjective norm and behavioural intent was not } \\
\text { significant, although behavioural intention was related to the coaches' } \\
\text { attitude ( } r=.335 \text { ), perceived knowledge ( } r=-.270 \text { ) and actual knowledge. ( } r= \\
\text {.304). } \\
\text { - There was a large discrepancy between coaches' perceived knowledge } \\
\text { (mean = 23.7) and actual knowledge (mean = 66.1). }\end{array}$ \\
\hline $\begin{array}{l}\text { Scarpino et al } \\
(1990)\end{array}$ & Italy & $\begin{array}{l}114 \text { coaches and } \\
\text { managers, } 1015 \text { Italian } \\
\text { athletes, } 102 \text { doctors } \\
(n=1231) \\
\text { Males }-67 \%\end{array}$ & $\begin{array}{l}\text { Questionnaire and Interview } \\
\text { [Key themes: knowledge of the } \\
\text { effects of drug use on athletic } \\
\text { performance; prevalence of doping } \\
\text { practices; availability of doping } \\
\text { agents; reasons for drug use] }\end{array}$ & $\begin{array}{l}\text { - The study did not clearly differentiate between coaches, managers and } \\
\text { doctors when discussing the rubric of 'technician'. } \\
\text { - Overall, } 30 \% \text { of athletes, coaches and managers indicated that athletic } \\
\text { performance could be enhanced by use of drugs and other doping practices. } \\
\text { - More than } 20 \% \text { of technicians (doctors, coaches and managers) stated that } \\
\text { anabolic steroids were being used frequently at national or international } \\
\text { level. } \\
\text { - A greater number of technicians indicated that doping was potentially } \\
\text { harmful than stated it was efficacious in improving performance. } \\
\text { - Over } 60 \% \text { of technicians reported that the } 7 \text { substances examined were } \\
\text { dangerous (over } 90 \% \text { for AS and amphetamines). }\end{array}$ \\
\hline
\end{tabular}


Table 8. Descriptive analysis of studies examining the attitudes of coaches and support staff towards doping in sport.

\begin{tabular}{|c|c|c|c|c|}
\hline $\begin{array}{c}\text { First author } \\
\text { (year) }\end{array}$ & Country & Sample & Methods & Summary \\
\hline Shields (1995) & US & $\begin{array}{l}215 \text { Athletic Directors' } \\
\text { (AD's) } \\
\text { Response rate }=66 \% \\
96 \% \text { male } \\
88 \% \text { aged between } 36-60 \\
\text { years. }\end{array}$ & $\begin{array}{l}\text { Questionnaire } \\
\text { [Key themes: observations and } \\
\text { perceptions of general substance } \\
\text { abuse amongst student athletes } \\
\text { and the general student body] }\end{array}$ & $\begin{array}{l}\text { - The percentage of AD's who perceived the drug problem to be 'very big' or } \\
\text { 'somewhat big' for student athletes was less than for students in the general } \\
\text { study body for } 10 \text { out of } 12 \text { specified drugs, including alcohol, tobacco and } \\
\text { marijuana. } \\
\text { - The perception of reduced drug use by athletes compared to other students } \\
\text { was consistent. } \\
\text { - The author asserts that this data presents a case for participation in athletics } \\
\text { as a deterrent to drug abuse. } \\
\text { - Corroboration of findings through other methods of investigation would be } \\
\text { necessary before this could be stated with any certainty. }\end{array}$ \\
\hline $\begin{array}{l}\text { Shirazi \& Tricker } \\
\text { (2005) }\end{array}$ & US & $\begin{array}{l}353 \text { Head Athletic } \\
\text { Trainers (HATS) } \\
\text { Range of US NCAA } \\
\text { institutions } \\
\text { Response rate }=66 \%\end{array}$ & $\begin{array}{l}\text { Questionnaire (20-items) } \\
\text { [Key themes: current athletic } \\
\text { department alcohol, tobacco and } \\
\text { other drug (ATOD) policies } \\
\text { operating in their college or } \\
\text { university; ecological model] }\end{array}$ & $\begin{array}{l}\text { - } 83 \% \text { of HATS reported having an ATOD policy in place. } \\
\text { - } 30 \% \text { of HATS indicated that ATOD courses were offered to students once a } \\
\text { year, compared to just } 1 \% \text { who reported courses were offered on a monthly } \\
\text { basis. } \\
\text { - ATOD courses generally covered topics relating to health }(65 \%) \text { and legal } \\
\text { aspects (41\%) of drug abuse, materials aimed at improving students' } \\
\text { decision-making skills ( } 35 \%) \text {. } \\
\text { - Programmes relating to assertiveness training, resisting peer pressure and } \\
\text { coping with the pressures of competition were often absent. } \\
\text { - HATS emphasised a need for athletic departments to develop long-term and } \\
\text { comprehensive ATOD programmes for athletes. } \\
\text { - The most frequently cited barriers to developing and evaluating ATOD } \\
\text { courses were inadequate guidelines on policy development and financial } \\
\text { and time constraints. }\end{array}$ \\
\hline $\begin{array}{l}\text { Starkey et al } \\
\text { (1994) }\end{array}$ & US & $\begin{array}{l}218 \text { Athletic Trainers } \\
\text { Response rate }=44 \% \\
\text { Predominantly male ( } 84 \%) \\
\text { Certified on average } 18 \\
\text { years }\end{array}$ & $\begin{array}{l}\text { Questionnaire (16-items) } \\
\text { [Key themes: attitudes towards the } \\
\text { drug screening of athletes and how } \\
\text { ATs view their role in the process] }\end{array}$ & $\begin{array}{l}\text { - } 62 \% \text { indicated their involvement in the university/college drug testing } \\
\text { programme placed them in dual role of being 'police' and 'counsellor'. } \\
\text { - Further } 73 \% \text { stated that they did not think that they should be involved in the } \\
\text { process of collecting urine specimen samples. } \\
\text { - Just under } 50 \% \text { of trainers felt that their involvement in the drug screening } \\
\text { process compromised their rapport with athletes. } \\
\text { - } 64 \% \text { stated that educational sessions relating to drug use must be } \\
\text { reinforced by actual implementation of the drug screening process. }\end{array}$ \\
\hline
\end{tabular}




\subsubsection{Discussion}

When one considers that only eight studies contributed to this line of research and acknowledges the considerable disparity in terms of sample characteristics and subject matter, it is apparent that caution must be exercised when drawing conclusions. Given the pivotal role that coaches can play in regulating athletes' attitudes and behaviour it is surprising that so few studies have been conducted on this population. However, based on such limited findings, it may be surmised that coaches and other athletic support staff across the spectrum of athletic performance are faced with doping in their work and hold a generally negative attitude towards doping, both in regard to its ethical position and its impact upon athlete health. Of those respondents asked, the majority acknowledged that they have a role to play in doping prevention, but were in need of additional education and/or support from relevant sporting or anti-doping organisations in order to take appropriate action.

A number of findings emerge from the evidence, which point toward some interesting opportunities for additional research in this field. Firstly, the perception by athletic directors that drug use by athletes was significantly lower than non-athletes ${ }^{110}$ is in contrast to a number of studies that have surveyed athletes directly. Melia et al ${ }^{78}$, for example, reported that student athletes, particularly those engaged in wrestling or American football, had higher rates for use of anabolic steroids than non-athletes. A second finding that warrants further investigation is that coaches and/or support staff may be engaging in doping behaviour themselves through the supply of agents to athletes. Clearly, coaches should also be a key target group for doping prevention initiatives and Dubin 30 has highlighted the importance of coaches as potential agents in the prevention of drug use amongst athletes and corroborates this assertion. Lastly, athletic trainers expressed concerns regarding the organisation and administration of drug testing for college athletes. Further research that seeks to clarify the attitudes of trainers towards drug testing in college would be of benefit.

Once again, a striking feature of this body of literature was the absence of informed research, guided by theoretical frameworks. Only one research team ${ }^{37}$ approached their investigation from a theoretical perspective, namely the Theory of Planned Behaviour ${ }^{2}$. Fung and Yuan ${ }^{37}$ used this as their guiding framework for questionnaire design and subsequent data analysis. This theory considers the relationships between attitudes, intentions and behaviour (Figure 1) and although some interesting findings emerged in relation to self-report attitude and behavioural intent, only partial agreement with 
the theory was noted. In contrast to attitudes, subjective norms were not found to significantly correlate with behavioural intentions. However, it could be argued that the three items used in the questionnaire to tap into subjective norm do not truly represent the coaches' perception of the subjective norm in relation to doping. For example, the subjective norm item "Doping is a serious problem in international sports" illustrates this point well. Furthermore, basic statistical techniques were employed which did not enable the tenets of the model to be fully examined and firm conclusions of the applicability of the model in the understanding the attitude-behaviour relationship in coaches cannot be offered at the present time. 


\section{$4 \quad$ ATTITUDES TOWARDS DOPING}

\subsection{Detailed Analysis - General Public}

\subsubsection{Background}

Four published studies were identified that examined attitudes towards doping amongst nonathletic adults (aged 18 years or above). Three studies were conducted in the United States ${ }^{106}$, 107, 130 and one in Australia 50. All studies explore attitudes towards anabolic steroid users as compared with other drug users or athletes subject to other forms of stigmatisation 50, 106, 107, 130 . A brief descriptive analysis of each study can be found in Table 9 and a detailed annotation in Appendix A.

\subsubsection{Sample}

All studies comprised samples of undergraduate students $106,107,130$ with sample size ranging from 139-399. Only Grove and Paccagnella 50 reported subjects age (mean $=20.3$ years) and

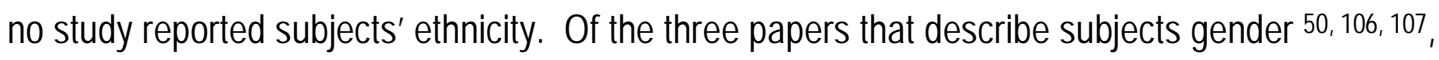
the mix was roughly equal.

\subsubsection{Method}

All studies employed a cross-sectional survey design and gathered data by questionnaire. Schwerin and Corcoran ${ }^{107}$ devised the Steroid Perception Questionnaire (SPQ), an 18-item inventory that assesses subjects' perceptions of a target individuals arousal and aggression, intelligence, relaxation and tension reduction, sexual enhancement, social assertiveness and global positive effects on a 4-point scale from 'definitely true' to 'definitely false'. The SPQ was also utilised by Van Raalte et al 130 and Schwerin and Corcoran ${ }^{106}$. Grove and Paccagnella 50 employed a questionnaire devised for the specific purposes of the study at hand, assessing subjects perception of a stigmatised athlete in terms of attraction, envy and ascribed personality traits (e.g., friendly vs. unfriendly; honest vs. dishonest).

Grove and Paccagnella 50 explored attitudes towards anabolic steroid users as compared to athletes that had been subject to other forms of stigmatisation (sexual, racial, medical). Schwerin 
and Corcoran 107 provided subjects with a written description of a bodybuilder under three conditions; (1) anabolic steroid user, (2) cocaine user or (3) non-drug user, who were then assessed by subjects using the SPQ. Van Raalte et al 130 replicated the study conducted by Schwerin and Corcoran ${ }^{107}$ with the addition of a 'cheating bodybuilder' condition. Schwerin and Corcoran 106 extended the work of Van Raalte et al 130 by presenting information on target subjects in visual format, rather than written, using a narrated slide show.

\subsubsection{General Findings}

In this sub-group steroid users were generally rated negatively compared to non-using counterparts in terms of intelligence, happiness, confidence, relaxation, social assertiveness and global positive effects ${ }^{107}$. Steroid users were viewed negatively compared to non-users in terms of trustworthiness, rule-orientation, integrity, honesty and self controlled ${ }^{50}$. The evidence generally suggested that anabolic steroid users were viewed in a similar manner to cocaine users 107 and athletes subject to other forms of stigmatisation such as those with HIV or homosexuals 50. There was some evidence to suggest that the manner in which an anabolic steroid user is presented may impact upon the way in which they are perceived. Findings from Schwerin and Corcoran 106, 107 indicate that when presented with a visual image of a steroid user, in contrast to a solely written description, users are perceived in a less negative manner. When provided with a visual stimulus, the steroid using bodybuilder was perceived similarly to a non-using counterpart on the intelligence and global positivity dimensions of the SPQ. 
Table 9. Descriptive analysis of studies examining knowledge, attitudes and beliefs of the general public on doping in sport.

\begin{tabular}{|c|c|c|c|c|}
\hline $\begin{array}{l}\text { First author } \\
\text { (year) }\end{array}$ & Country & Sample & Methods & Summary \\
\hline $\begin{array}{l}\text { Grove \& } \\
\text { Paccagnella } \\
\text { (1995) }\end{array}$ & US & $\begin{array}{l}139 \text { University Students } \\
\text { Mean age }=20.38 \text { years } \\
\text { Males }(43 \%) \text {, females } \\
(57 \%)\end{array}$ & $\begin{array}{l}\text { Questionnaire } \\
\text { [Key themes: Tall Poppy } \\
\text { Syndrome' attitudes to high-profile } \\
\text { athletes; stigmatisation] }\end{array}$ & $\begin{array}{l}\text { - Subjects would rather be similar to athletes in group B than A. They would } \\
\text { like these athletes more and be happier to spend time socially with them. } \\
\text { - Athletes from group A were considered to be less trustworthy, rule- } \\
\text { orientated or honest and have less integrity and self-control. } \\
\text { - Athletes who are perceived to violate the generally conservative values } \\
\text { upheld in sport, such as fair play, discipline and achievement through hard } \\
\text { work, are subject to harsh judgement. }\end{array}$ \\
\hline $\begin{array}{l}\text { Schwerin \& } \\
\text { Corcoran (1992) }\end{array}$ & US & $\begin{array}{l}276 \text { University } \\
\text { Psychology Students }\end{array}$ & $\begin{array}{l}\text { Written Stimulus Presentation \& } \\
\text { Steroid Perception } \\
\text { Questionnaire (Schwerin \& } \\
\text { Corcoran, 1992) } \\
\text { [Key themes: perceptions of } \\
\text { psychology students of an AS } \\
\text { users] }\end{array}$ & $\begin{array}{l}\text { - Results indicated that subjects viewed the bodybuilding steroid-user } \\
\text { significantly more negatively than the drug-free bodybuilder or the } \\
\text { athletically active individual. } \\
\text { - The steroid user was seen as less intelligent, interesting, happy, confident } \\
\text { and relaxed compared to non-using athletes. } \\
\text { - A cocaine-using bodybuilder and a steroid-using bodybuilder were viewed } \\
\text { similarly. }\end{array}$ \\
\hline $\begin{array}{l}\text { Schwerin \& } \\
\text { Corcoran (1996) }\end{array}$ & US & $\begin{array}{l}399 \text { University } \\
\text { Psychology Students } \\
\text { The study extended } \\
\text { previous work (see } \\
\text { Schwerin and Corcoran, } \\
\text { 1992) }\end{array}$ & $\begin{array}{l}\text { Visual Stimulus Presentation \& } \\
\text { Steroid Perception } \\
\text { Questionnaire (Schwerin \& } \\
\text { Corcoran, 1992) } \\
\text { [Key themes: perceptions of } \\
\text { psychology students of a male AS } \\
\text { user bodybuilder] }\end{array}$ & $\begin{array}{l}\text { - Steroid using bodybuilder was generally viewed negatively compared to } \\
\text { drug-free counterparts. } \\
\text { - Steroid using bodybuilders were rated poorly on constructs relating to social } \\
\text { assertiveness, tension reduction, global positive perceptions and } \\
\text { intelligence. } \\
\text { - Ratings of intelligence and global positive enhancement changed for the } \\
\text { steroid using protagonist with the change from written to visual mode of } \\
\text { representation. Ratings were more positive after the visual mode of } \\
\text { presentation, suggesting that visual information may mitigate negative } \\
\text { attitudes about drug use, possible as a result of the visible physical effects } \\
\text { apparent in this form of presentation. }\end{array}$ \\
\hline $\begin{array}{l}\text { Van Raalte et al } \\
(1993) \\
\text { Study replicates } \\
\text { and extends } \\
\text { research } \\
\text { conducted by } \\
\text { Schwerin and } \\
\text { Corcoran (1992) }\end{array}$ & US & $\begin{array}{l}\text { Mixed sample }(n=319) \\
\text { Experiment } 1-22 \text { AS } \\
\text { using bodybuilders \& } \\
\text { powerlifters } \\
\text { Exp } 2-43 \text { non-using } \\
\text { athletes } \\
\text { Exp } 3-254 \\
\text { undergraduates }\end{array}$ & $\begin{array}{l}\text { Steroid Perception } \\
\text { Questionnaire (Schwerin \& } \\
\text { Corcoran, 1992) } \\
\text { [Key themes: AS using athletes - } \\
\text { perceptions of others; story } \\
\text { protagonist] }\end{array}$ & $\begin{array}{l}\text { - Undergraduate students viewed the steroid user more negatively than both } \\
\text { the diet conscious athlete and diet conscious bodybuilder. }\end{array}$ \\
\hline
\end{tabular}




\subsubsection{Discussion}

Given the scarcity of research in this field a detailed discussion of the findings is not appropriate or possible. To date, the majority of research has focused upon attitudes towards anabolic steroid users, with the evidence suggesting that users are generally viewed negatively in terms of personality, in a similar manner to other drug users and stigmatised athletes. There was evidence to suggest that attitudes towards anabolic steroid users may be mediated by the manner in which information about them is presented. Specifically, visual information may serve to mitigate negative attitudes towards an individuals drug use. A possible explanation for this is that when people see the effects of steroid use, their negative perceptions of the user are mediated by the tangible physical effects of use. An understanding of those factors which influence people's attitudes towards anabolic steroid users, or doping users in general, may be of benefit when devising intervention programmes. 


\section{$4 \quad$ ATTITUDES TOWARDS DOPING IN SPORT}

\subsection{Attitudes section overview and synopsis}

\subsubsection{Background}

Sixty nine papers were identified that described attitudes, beliefs and knowledge of doping or drug testing amongst various populations (Table 10). Overall, thirty eight studies were conducted in the United States 7, 9, 13, 15, 22-26, 28, 34, 45, 50, 54, 56, 59, 60, 82, 86, 87, 90, 96, 98, 102, 105-107, 110, 112, 116, 117, 123, 127, 130, 134, 135, 138, 139, eight in the United Kingdom 21, 46, 77, 80, 95, 133, 137, six in France 64-68, 94, four in Australia ${ }^{11,12,51,89}$, two in Canada 78,115 , and one each in Cameroon ${ }^{8}$, Finland ${ }^{6}$, Germany ${ }^{121}$, Italy ${ }^{103}$, Nigeria ${ }^{85}$, Norway ${ }^{34}$, Sweden ${ }^{69}$, West Indies ${ }^{74}$, Turkey ${ }^{88}$, Hong Kong ${ }^{37}$ and Greece 91.

Table 10. Empirical studies examining knowledge, attitudes and beliefs.

\begin{tabular}{|c|c|c|}
\hline $\begin{array}{l}\text { Target } \\
\text { Group }\end{array}$ & $\begin{array}{l}\text { No. of } \\
\text { Studies }\end{array}$ & $\begin{array}{l}\text { Number of studies and References } \\
\text { (First author and year only) }\end{array}$ \\
\hline Elite Athletes & 14 & $\begin{array}{l}\text { Wagman, 1995; Alaranta, 2006; Ama, 2003; Anshel, 1991; Anshel, 1997; Chester, 2003; Laure, 1995; } \\
\text { McCardle, 1999; Ohaeri, 1993; Peretti-Watel, 2004; Scarpino, 1990; Somerville, 2005; Striegel, 2002; } \\
\text { Waddington, 2005; Ama, 2003; Ozdemir, } 2005\end{array}$ \\
\hline $\begin{array}{l}\text { College/Uni } \\
\text { \& High } \\
\text { School } \\
\text { Athletes }\end{array}$ & 25 & $\begin{array}{l}\text { Laure, 2004; Albrecht, 1992; Anderson, 1991; Chng, 1990; Coombs, 1991; Coombs, 1990; Diacin, } \\
\text { 2003; Gray, 1993; Hamilton, 1990; Kersey, 1996; Pan, 1998; Peters, 2005; Schneider, 1993; Tricker, } \\
\text { 1997; Yesalis, 1990; Spence, 1996; Paccagnella, 1997; Bents, 2004; Corbin, 1994; Naylor, 2001; } \\
\text { Stilger, 1999; Terney, 1990; Warner, 2002; Wroble, 2002; Melia, } 1996\end{array}$ \\
\hline $\begin{array}{l}\text { Bodybuilders, } \\
\text { Powerlifters } \\
\text { \& Gym users }\end{array}$ & 13 & $\begin{array}{l}\text { Ardito, 1994; Curry, 1999; Kersey, 1993; Olrich, 1999; Olrich, 1999; Pope, 1988; Schwerin, 1996; Van } \\
\text { Raalte, 1993; Wagman, 1995; Wright, 2001; Monaghan, 2002; Lindstrom, 1990; Maharaj, } 2000\end{array}$ \\
\hline $\begin{array}{l}\text { Coaches \& } \\
\text { support staff }\end{array}$ & 7 & $\begin{array}{l}\text { Shields, 1995; Shirazi, 2005; Starkey, 1994; Fjeldheim, 1992; Scarpino, 1990; Laure, 2001; Fung, } \\
2006\end{array}$ \\
\hline $\begin{array}{l}\text { Medical } \\
\text { Professionals }\end{array}$ & 8 & $\begin{array}{l}\text { Laure, 2000; Laure, 2003; Greenway, 1997; Perry, 1994; Gupta, 1997; Salva, 1991; Scarpino, 1990; } \\
\text { Panagiotis, } 2006\end{array}$ \\
\hline $\begin{array}{l}\text { General } \\
\text { Public }\end{array}$ & 4 & \{Grove, 1995; Schwerin, 1992; Schwerin, 1996; Van Raalte, 1993 \\
\hline
\end{tabular}

\subsubsection{Sample}

Total sample across all studies was approximately 49 564, with a range of 828 to 1616978 .

Males dominated the literature and only 6 studies utilised samples in which $50 \%$ or more of the 
participants were female 50,54,96, 106, 107, 123. Furthermore, numerous studies failed to provide information on the gender of the sample $7,34,46,78,90,102,112,117,127,130$ and few studies reported subjects ethnicity, of which ten utilised samples comprising greater than $70 \%$ White or Caucasian subjects $7,9,13,26,28,86,87,98,117,137$.

\subsubsection{Methods}

All studies employed a cross-sectional design and with the exception of four studies, which utilised qualitative research methodologies 28,86,87, all administered self-report questionnaires. In the context of this research domain, Monaghan 80 adopted a unique approach and conducted indepth interviews and participant observation methods to collect data for an ethnographic study of bodybuilders. All but six studies 105, 106, 127, 130, 134 employed questionnaires that were devised by the investigators for the specific research project at hand and they were not subject to psychometric validation. The use of psychometrically sound instruments is not a feature of this literature, however, a number of researchers have employed inventories that have received some psychometric testing, albeit early stage validation. Schwerin and Corcoran ${ }^{106}$ and Van Raalte et al 130 have employed the Steroid Perception Questionnaire, previously devised and administered by Schwerin and Corcoran 107. Schwerin and Corcoran 107 used the Beliefs About Steroids Scale (BASS) developed by Carney and Corcoran 20 , whilst Tricker and Connolly 127 and Wagman et al 134 used the King Drugs in Sport Questionnaire (KDSQ), drawn from an unpublished doctoral publication 61 .

\subsubsection{Discussion}

Although not extensive, a number of empirical investigations have attempted to examine the attitudes towards doping of various target groups, including elite athletes and coaches and support staff. An examination of the last sixteen years of this line of inquiry has revealed a lack of knowledge and understanding in relation to this social science research theme. Progress has been identified in some areas, such as the rudimentary development of performance enhancing drug use models by Donovan and colleagues ${ }^{29}$ and Strelan and Boeckmann ${ }^{119}$ and the basic application of attitude-behaviour theoretical frameworks to study design and evaluation 37, 96, 127, but advancement appears slow and unsystematic. Some tentative conclusions that span the target groups examined will now be offered. 


\section{- Prevalence}

Establishing prevalence of drug use in sport was not an objective of this review. However, given the behaviour focus it was worth noting that a consistent finding emerged across the body of research. Athletes across all sporting disciplines are committing doping violations, or perceive their team mates or competitors to be doing so. Self-reported incidence was consistently higher in males compared to females. Further, when asked to estimate competitor and team mate use, the statistics were much higher than when personal use was reported. At the present time, a reliable estimate of prevalence is yet to be established.

\section{- Attitudes towards doping}

In general, based upon self-report questionnaire findings, negative attitudes towards doping prevail in all groups examined except the bodybuilding and powerlifting community. However, across target groups, it appears that ambivalent attitudes co-exist and athletes state that they would be complicit to the use of doping agents under the 'right conditions' if it led to performance success.

\section{- Attitudes towards drug testing programmes}

Overall, self-reports demonstrated that target groups have a positive attitude towards drug testing and support its role in the prevention of drug use. However, sub-groups acknowledge the need for further testing programme development and improvement and across the body of literature concerns were raised regarding the validity, integrity and efficacy of the testing system and methods of detection.

\section{- Knowledge}

Knowledge of the effects of performance enhancing drug use, drug testing procedures, etc. were examined across the target groups, albeit sporadically. Deficits in knowledge emerged. For example, the few studies that considered the medical profession identified a limited understanding of the effects of doping and a poor awareness of the banned list in this group of professionals. Furthermore, elite athletes, college athletes and school-age children also demonstrated a lack of basic awareness of testing procedures and doping effects.

\subsubsection{Attitude research limitations}

Although progress has been made in this field, there is arguably much to do if we are to understand the real nature of target group attitudes towards doping in sport. The aim of the 
following discussion is to highlight a number of the inherent limitations of the studies reviewed; it does not represent an exhaustive list. We hope this reflection will help stimulate debate and guide future research agendas. The expectancy-value model of attitudes (e.g., Theory of Reasoned Action ${ }^{2}$ and Planned Behaviour ${ }^{5}$ has provided a useful framework for guiding research on attitudes towards doping in sport, but an enduring group of adherents to the pursuit of this line of enquiry is not evident. Consequently, there is limited debate across research teams and this hinders research momentum. At present, the findings do not suggest a causal link between attitudes and beliefs and performance enhancing drug use. However, this conclusion is perhaps not surprising when one realises that research to date has tended to collect data which elicits hypothesis generation rather than causality testing. It is true to say that exploratory investigation and preliminary findings dominate this literature.

\section{- Nature of attitudes}

It is apparent that this field trails behind mainstream attitude research and only really scratches the surface, so to speak, when considering this construct in relation to human behaviour and doping. The underlying structure of attitudes in not often defined or considered in the doping literature and, at times, the construct appears misinterpreted and poorly understood. In addition, recent developments in attitude-behaviour research have not transferred to the doping domain and consequently much work is to be done if we are to establish causal relationships between attitudes and performance enhancing drug use behaviours. For example, research on automatic attitude activation and the use of response latencies to obtain measures of attitudes that are free from reactive effects is being encouraged ${ }^{3}$, particularly when researchers are assessing attitudes towards socially sensitive issues, such as doping in sport. Research ${ }^{3}$ suggests that individuals can hold two different attitudes towards a given object in the same context, one attitude that is implicit or habitual and the other explicit. It seems timely to suggest the need to consider implicit attitude examination towards performance enhancing drug use (Petroczi, personal communication) instead of relying solely on explicit attitude measurement which could be subject to self-impression management ${ }^{97}$. Such an approach could prove insightful given the suggestion that target groups appear to hold ambivalent attitudes towards doping in sport. For example, across a number of studies examining elite athletes, college athletes and school age children, respondents report that they believe doping is cheating and against the spirit of sport but a 
percentage of those report that they would (intention) experiment with performance enhancing drugs if such an act would guarantee them an Olympic medal or they were able to avoid detection. According to Ajzen ${ }^{3}$, holding ambivalent attitudes affects judgements and behaviour in profound ways and attitudinal ambivalence could be a promising area of research in understanding the effects of attitudes on doping behaviour.

Finally, the doping field appears not to have acknowledged or recognised the interactive nature of attitudes which are influenced by cognition (i.e., beliefs) and affect (i.e., feelings). Research in mainstream social psychology suggests that when both these attitude elements are considered, one obtains a better prediction of the overall attitude of the respondent and of the reported behaviour ${ }^{3}$. Moreover, Haddock and Zanna 52 purport that there are 'thinkers' and 'feelers' and individuals differ in their tendency to base their attitudes towards a target object on cognition and affect. This proposition has not been considered by researchers interested in the attitude-doping behaviour link and the development of a model that captures individual differences in this thinking/feeling tendency could be beneficial to understanding the highly complex nature of doping in sport.

\section{- Reliance on self-report methodologies}

At the present time, this literature is dominated by US research teams. In addition to this skewed representation, it is difficult to reach evidence-based conclusions at the present time due to inherent flaws in research methodologies employed or the manner in which the research findings are reported. Such limitations may explain why few articles are published in high impact factor scientific journals because the majority of manuscripts examined would not pass the initial screening phase of highly esteemed journals because a number fail to appropriately articulate the methods of investigation or sample characteristics in sufficient detail, or present only limited description and analysis of the study findings. More specifically, the articles present research designs that sit in the lower echelons of the hierarchy of research evidence. The finding that the overwhelming majority of research in this review has been conducted using self-report methodologies explains one of the reasons for this position within the hierarchy. Also, self-report surveys raise questions of self-presentation bias and this limitation is exacerbated by the fact that the majority of inventories have not been psychometrically tested. Indeed, over $91 \%$ of the 
studies reviewed had employed questionnaires which were designed by the research team, with little consideration for the questionnaires psychometric properties.

\section{- Demographic mix}

Many studies failed to report even the most basic demographic information such as gender and age. However, those studies that did provide such detail highlighted an uneven gender sampling - with males dominating this research field. More specifically, less than $50 \%$ of the sample was female in over $91 \%$ of the investigations pertaining to knowledge, attitudes and beliefs.

Furthermore, fewer studies actually reported the ethnic mix of their responses and the limited studies that did were dominated by Caucasian respondents. 


\section{EDUCATION AND INTERVENTION PROGRAMMES}

\subsection{Background}

Sixteen papers were retrieved that described anti-doping education or intervention programmes; two studies present theoretical models 29,119 to explain key factors that influence doping behaviour, three papers describe a model for a drug and/or alcohol abuse prevention programme 47-49, seven papers describe drug and/or alcohol intervention programmes 31, 39-42, 44, 73, 125, 126 and one article discusses practical strategies for coaches and sport psychologists to reduce doping behaviours amongst their teams ${ }^{10}$. One study ${ }^{43}$ describes the effects of SATURN - a mandatory drug testing programme in two Oregon high schools. Overall, the majority of studies were conducted in the United States 31,39-44, 47-49,73, 125, 126, although three studies were conducted in Australia 10,29,119. Some retrieved papers represent studies reported in others of our sample of sixteen.

\section{$5.2 \quad$ Sample}

Across the seven studies with the most demanding research designs (Table 11) the total sample was approximately 5845, with a mean of 835 subjects per study. However, sample size varied from 35125 to 3207 44. Five papers report on interventions conducted with high school athletes, all of whom were male American football players aged approximately $14-18$ years $39-42,44$. Of the remaining two papers, one describes an intervention with male junior school wrestlers aged 9-12 years 125 and the other a programme aimed at university athletes (32\% female) from a range of sports ${ }^{126}$. Tricker and Connolly ${ }^{126}$ did not provide details of subject age but was the only study to collect female data. However, the sample was weighted in favour of males and findings were not separated by sex during analysis. Only three articles reported ethnicity 41,42,44. Participants were predominantly white in each of these studies, with fewer than $5 \%$ of respondents identifying themselves as Asian, Native American, Hispanic, African American or mixed heritage. In the SATURN study 43 the sample reflected school enrolment with Caucasian domination (83.8\%).

\subsection{Design}

Five studies used random assignment designs 29, 39, 44, 125, but none provided details of the randomisation procedure. All seven studies employed a control group to compare intervention 
effects, placing these studies in the higher echelons of the hierarchy of evidence. Self-report questionnaires assessed knowledge, attitudes and intentions before and after interventions were implemented. Tricker and Conolly ${ }^{126}$ gathered data using the previously validated King Drug in Sport Questionnaire (KDISQ) and the Decision Making Questionnaire (DMQ). Goldberg et al 41 devised and validated a 299-item questionnaire, which was shortened in subsequent studies 42 , 44. This device was consistent with the stated perspective of AAS use as a learned, goal-directed activity, reinforced by individual, peer, family, community or school influences (p.714).

Trenhaile et al ${ }^{125}$ devised and validated the Anabolic Steroid Knowledge Questionnaire (ASKQ) and utilised a modified version of the D.A.R.E Program Student Questionnaire (DARESQ) to gather information. Goldberg et al 39,40 revised existing questionnaires to their needs, but provided no details of psychometric testing.

Six studies employed interventions targeting anabolic steroid abuse 39-42, 44,125. Tricker and Connolly ${ }^{126}$ addressed drug use in a wider context to include recreational (alcohol, tobacco, marijuana) and performance enhancing drugs (anabolic steroids, human growth hormone, amphetamines). Goldberg et al. ${ }^{43}$ evaluated the effects of a random drug testing approach in a high school, based on a non-punitive mandatory, random, suspicion-free drug testing policy (p.17) system in western USA over a single school year. Social Learning Theory informed the development of the Adolescents Training and Learning to Avoid Steroids (ATLAS) programme, delivered to varsity football players in two urban high schools. This study is described in a range of articles reviewed here $41,42,44,73$ and for the sister ATHENA study (Athletes Targeting Healthy Exercise and Nutrition Alternatives) ${ }^{31}$. All remaining interventions were informed by analysis of previous research but without reference to a particular theory or perspective.

Duration of intervention and follow-up varied greatly from 2 weeks to approximately 12 months. Three studies 29, 39, 125, completed baseline testing, intervention and post-testing within a 2-3 week period, with no long term follow-up. Goldberg et al conducted follow-up testing 1 week after the final session of an 8 week intervention. Tricker and Connolly ${ }^{126}$ assessed subjects at the beginning and end of a 10 week drug education programme. Two studies ${ }^{42,44}$ conducted longterm follow-up of intervention effects, conducting post tests approximately 12 months after 
baseline assessment. Overall, there have been few attempts to determine the optimum duration for an intervention programme and only a minority of studies have assessed effectiveness over an extended period of follow-up.

\subsection{Intervention Components}

All studies sought to improve subjects' knowledge by providing information in the form of lectures or classroom based sessions. Five studies also provided subjects with printed materials in the form of a short pamphlet describing effects of particular drugs (anabolic steroids) ${ }^{29,39}$ or booklets giving advice on appropriate nutrition and weight training practices $41,42,44$. Tricker and Connolly 126 also required subjects to complete written assignments and an oral presentation.

Four papers $41,42,44,73$ describe applications of the ATLAS intervention. The ATLAS programme comprised $8 \times 1$-hour sessions led by a peer or coach in classrooms, focusing on nutrition and physiology information, role playing, effects of anabolic steroids and analysis of steroid messages in the media. Classroom sessions were supplemented by weight room sessions delivered by research staff aimed at educating users in appropriate and effective strength training techniques.

Trenhaile et al 125 also employed classroom based sessions, which addressed psychological and physiological effects of steroids, weight training techniques, nutrition, decision making and selfesteem training. The rationale behind including weight training or nutritional educational in an intervention programme is to ensure that subjects are gaining optimal benefits from their training, thus providing a legitimate alternative to doping that may improve their performance. Tricker and Connolly ${ }^{126}$ conducted a three-stage intervention including education and discussion about performance enhancing and recreational drugs, life skills training and a group presentation on a drug related topic as chosen by the students. Two studies 39,40 conducted interventions that served exclusively to provide subjects with information about anabolic steroids. Goldberg et al 39 compared effects of a balanced programme exploring potential positive and negative consequences of steroid use with a biased programme that focused solely upon adverse effects. Goldberg et al ${ }^{40}$ contrasted the effects of a lecture plus handout intervention with a handout only condition. To date, the majority of intervention based research in this field has focused upon reducing or preventing the use of anabolic steroids. 


\subsection{Effectiveness}

No study quantified intervention effects using effect size statistics (Eta-squared, Cohen's $d$ ). Six of seven studies improved experimental subjects' knowledge of drug or alcohol issues in general 126 or of a specific drug (anabolic steroids) compared to controls 40-42, 44, 125. Five studies $41,42,44$, 125,126 also reported significant changes in attitude amongst intervention subjects. Changes in attitude scores related to perceived severity of and susceptibility to adverse affects of drug use 42 , 44, 126 , having negative attitudes towards other drug users ${ }^{42}$, using drugs as a way to solve problems ${ }^{41}$, perceived efficacy of performance enhancing substances and beliefs regarding the need for drugs to be successful in sport ${ }^{126}$.

Of the three intervention studies that assessed intentions to use drugs $41,42,44$, all reported that experimental subjects indicated lower intentions to use anabolic steroids compared to controls, with these effects persisting at long-term follow up in two studies 42,44 . Three studies examined changes in behaviour before and after intervention programmes 42, 44, 126. Tricker and Connolly 126 reported no significant differences in drug or alcohol use between control and experimental subjects following a 10-week drug education programme. Goldberg et al ${ }^{42}$ and Goldberg et al 44 reported significantly improved nutrition behaviours for experimental subjects compared to controls following a classroom and weight-room based intervention. There was a trend toward an increased number of new steroid users in control groups compared to experimental groups in both of these studies, but differences failed to attain long-term significance. Three studies assessed changes in self-esteem; 2 reported improved self-esteem for experimental subjects compared to controls 42,44 and one reported no change ${ }^{125}$. 
Table 11. Descriptive analysis of the key findings from doping intervention programmes.

\begin{tabular}{|c|c|c|}
\hline First author (year) & Intervention Components & Results \\
\hline Goldberg et al (1990) & $\begin{array}{l}\text { 3 conditions. } \\
\text { 1. } 20 \text { minute presentation reflecting ACSM position } \\
\text { statement, Q and A session, printed handout covering } \\
\text { presentation material. } \\
\text { 2. Printed handout only. } \\
\text { 3. None-intervention control group. } \\
\text { Approximate intervention duration: } 60 \text { mins } \\
\text { Approximate follow-up duration: } 2 \text { weeks } \\
\end{array}$ & $\begin{array}{l}\text { - Group } 1 \text { improved knowledge on } 6 \text { steroid related items [steroids causing cancer }(\mathrm{P}<0.05) \\
\text { sterility, liver damage, aggressive behaviour }(\mathrm{P}<0.005) \text {, acne, elevated cholesterol }(\mathrm{P}< \\
\text { 0.001)] compared to control group. } \\
\text { - Group } 2 \text { improved knowledge on } 3 \text { steroid related items [steroids causing acne }(\mathrm{P}<0.005) \text {, } \\
\text { sterility, elevated cholesterol }(\mathrm{P}<0.05) \text { compared to control group. } \\
\text { - Group } 1 \text { improved knowledge on } 2 \text { knowledge related items [steroids causing acne }(\mathrm{P}< \\
\text {-01), aggressive behaviour }(\mathrm{P}<0.05) \text { compared to group } 2 \text {. } \\
\text { - No changes in attitude scores for any group after intervention. }\end{array}$ \\
\hline Goldberg et al (1991) & $\begin{array}{l}\text { 3 conditions. } \\
\text { 1. } 20 \text { minute presentation reflecting ACSM position } \\
\text { statement, Q and A session, printed handout covering } \\
\text { presentation material. } \\
\text { 2. } 20 \text { minute presentation on adverse effects of anabolic } \\
\text { steroids, printed handout covering presentation } \\
\text { material. } \\
\text { 3. None-intervention control group. } \\
\text { Approximate intervention duration: } 60 \text { mins } \\
\text { Approximate follow-up duration: } 2 \text { weeks }\end{array}$ & $\begin{array}{l}\text { - Group } 1 \text { improved knowledge on } 5 \text { steroid related items [steroids causing cancer, heart } \\
\text { disease }(P<0.05) \text {, breast enlargement, liver damage }(P<0.01) \text {, acne }(P<0.001) \\
\text { compared to control group. } \\
\text { - Group } 1 \text { also improved knowledge of } 4 \text { steroid related items [steroids causing cancer, heart } \\
\text { disease, sterility }(P<0.05) \text {, breast enlargement }(P<0.001) \text { compared to group } 2 \text {. } \\
\text { - No changes in attitude scores for any group after intervention. }\end{array}$ \\
\hline Goldberg et al (1996) & $\begin{array}{l}\text { - } 16 \times 60 \text { minute sessions (coach / peer lead). } \\
\text { - } 8 \times \text { classroom sessions: Sports nutrition, strength } \\
\text { training techniques, drug refusal skills, anti-steroid media } \\
\text { messages. } \\
\text { - } 8 \times \text { weight room sessions: demonstration of good weight } \\
\text { training methods and techniques. } \\
\text { Approximate intervention duration: } 8 \text { wks } \\
\text { Approximate follow-up duration: } 8 \text { wks }\end{array}$ & $\begin{array}{l}\text { - Experimental subjects reported lower intentions to use steroids }(P<0.1) \text { and lower } \\
\text { intentions to use steroids to reach a goal }(P<0.1) \text { than control subjects } \\
\text { - Experimental subjects showed improved knowledge of alternatives to steroid use }(P< \\
0.01) \text {, dietary supplements }(P<0.05) \text { and the effects of steroids }(P<0.01) \text {. } \\
\text { - Scores on attitude scales relating to "win at all costs" }(P<0.1) \text { and "drugs will solve all } \\
\text { problems" }(P<0.1) \text { improved amongst experimental subjects compared with controls. }\end{array}$ \\
\hline Goldberg et al (1996) & $\begin{array}{l}\text { - } 14 \times 50 \text { minute sessions. (coach / peer lead) } \\
\text { - } 7 \times \text { classroom sessions: Sports nutrition, strength } \\
\text { training techniques, drug refusal skills, anti-steroid media } \\
\text { messages. } \\
\text { - } 7 \times \text { weight room sessions: demonstration of weight } \\
\text { training methods and techniques. } \\
\text { Approximate intervention duration: } 7 \text { wks } \\
\text { Approximate follow-up duration: } 9-12 \text { months }\end{array}$ & $\begin{array}{l}\text { - Experimental subjects reported lower short term }(P<0.009) \text { and long term intentions to use } \\
\text { anabolic steroids }(P<0.02) \text { compared to controls. } \\
\text { - Intervention subjects reported improved sports nutrition behaviours }(P<0.001) \text { and greater } \\
\text { use of school rather than private gyms }(P<0.001) \text { following intervention compared with } \\
\text { controls. } \\
\text { - Experimental subjects were more likely than controls to believe in the potential severity of } \\
\text { anabolic steroid use }(P<0.001) \text {, had more unfavourable attitudes toward steroid users }(P< \\
0.01) \text { and felt more personal vulnerability to adverse effects of steroids }(P<0.01) \text {. }\end{array}$ \\
\hline
\end{tabular}


Table 11. Descriptive analysis of the key findings from doping intervention programmes.

\begin{tabular}{|c|c|c|}
\hline First author (year) & Intervention Components & Results \\
\hline Goldberg et al (2000) & $\begin{array}{l}\text { - } 14 \times 45 \text { minute sessions. (coach / peer lead) } \\
\text { - } 7 \times \text { classroom sessions: Sports nutrition, strength } \\
\text { training techniques, drug refusal skills, anti-steroid media } \\
\text { messages. } \\
\text { - } 7 \times \text { weight room sessions: demonstration of weight } \\
\text { training methods and techniques. } \\
\text { Participants from } 2^{\text {nd }} / \text { 3rd }^{\text {rd }} \text { year cohorts received condensed } \\
\text { intervention covering identical material ( } 5 \times \text { classroom, } 3 \times \\
\text { weight room sessions) } \\
\text { Approximate intervention duration: } 7 \text { wks } \\
\text { Approximate follow-up duration: } 1 \text { semester and } 1 \text { year. }\end{array}$ & $\begin{array}{l}\text { - At the end of the semester, use of anabolic steroids was lower in intervention subjects than } \\
\text { - } 0 \text { ntrols }(P<0.04) \text {, though this reduction was not evident at long term follow-up }(P<0.08) \text {. } \\
\text { - Subjects in the experimental group reported lower intentions to use anabolic steroids at the } \\
\text { - Intervention subjerts }(P<0.05) \text { and } 1 \text { year later }(P<0.03) \text { than controls } \\
\text { supplements, anabolic steroids and alcohol at both short and long-term follow up }(P<0.001 \\
\text { both) compared with controls. } \\
\text { - Experimental subjects more strongly believed that steroids had harmful effects and } \\
\text { perceived greater susceptibility to adverse effects than controls at both follow-up } \\
\text { assessments }(P<0.001 \text { both). }\end{array}$ \\
\hline Trenhaile et al (1998) & $\begin{array}{l}6 \times 30 \text { minute sessions. } \\
\text { 1. Weight training techniques; } 2 \text {. Nutrition information; } \\
\text { 3. Social-decision making; } 4 \text {. Self-esteem training; } \\
\text { 5. Psychological effects of anabolic steroids; } \\
\text { 6. Physiological effects of anabolic steroids } \\
\text { Approximate intervention duration: } 2 \text { wks } \\
\text { Approximate follow-up duration: } 2 \text { wks }\end{array}$ & $\begin{array}{l}\text { - Intervention subjects improved knowledge of anabolic steroids compared to controls }(P< \\
0.01) \\
\text { - Intervention subjects showed positive changes in 'overall attitude' (none specified) }(P< \\
0.01) \text { and attitudes toward anabolic steroids compared to controls }(P<0.01) \\
\text { - No differences were observed for self-esteem or peer resistance scores between control } \\
\text { and intervention subjects. }\end{array}$ \\
\hline $\begin{array}{l}\text { Tricker and Connolly } \\
\text { (1996) }\end{array}$ & $\begin{array}{l}\text { Information, education and discussion about performance } \\
\text { enhancing, medicinal and recreational drugs. } \\
\text { Written assignments, group presentation. } \\
\text { Approximate intervention duration: } 10 \text { wks } \\
\text { Approximate follow-up duration: } 1 \text { semester }\end{array}$ & $\begin{array}{l}\text { - Compared to controls, intervention subjects showed improved knowledge of anabolic } \\
\text { steroids }\left(X^{2}=9.49, P=0.02\right) \text {, human growth hormone }\left(X^{2}=21.13, P=0.01\right) \text {, cocaine }\left(X^{2}=\right. \\
13.30, P=0.003) \text {, amphetamines }\left(X^{2}=19.16, P=0.001\right) \\
\text { - Compared to controls, fewer intervention subjects indicated they: } \\
\text { - "would use steroids to help the team" ( } P=0.002) \\
\text { - "needed steroids to be competitive" }(P=0.033) \\
\text { - "use amphetamines to prevent fatigue during workouts" }(P=0.013) \\
\text { - "needed amphetamines to succeed in their sport" }(P=0.003) \text {. } \\
\text { - No significant differences in drug use were observed between intervention and control } \\
\text { subjects. }\end{array}$ \\
\hline
\end{tabular}




\subsection{Discussion}

The majority of studies in this field have sought to improve knowledge, attitudes and intentions towards anabolic steroid use amongst male college or university athletes. Most were also involved in power-related sports. It is evident that programmes which focus solely upon providing subjects with information on the effects of anabolic steroids are ineffective in reducing risk factors for use. Successful intervention strategies have adopted a comprehensive, multi-faceted approach to drug use prevention, addressing a range of psycho-social variables including peer and media resistance training, body image and self-esteem issues and alternatives to drug use. The Adolescents Training and Learning to Avoid Steroid (ATLAS) programme is the most well researched intervention initiative to date, and the only programme that has been systematically monitored over an extended period of follow-up $41,42,44$.

One strength of the ATLAS programme is that it is conducted on a team format with large segments of the intervention lead by coaches or peers, allowing for reinforcement of classroom material during other team (training) sessions. Accordingly, the amount of time that subjects are exposed to key intervention messages is increased beyond the time spent in classes and weight room based sessions. Further, the potential transferability of this delivery is enhanced by engaging local staff and influential local athletes.

Educating athletes about the effects of drugs, and specifically the adverse effects, may be a means of deterring drug use ${ }^{53}$. However, this contention is not supported in the present review. Studies that employed interventions designed solely to provide subjects with information regarding drug use (anabolic steroids) in either a balanced format 40 or with an emphasis on adverse consequences ${ }^{39}$, were not effective to altering subjects' attitudes or intentions. Whilst providing information on drug-related issues and improving knowledge is necessary, an effective programme must also address the myriad of other variables that impact upon the decision to use performance enhancing drugs, such as alternatives to drug use, peer and media resistance training and decision-making skills. Another intervention, highlighted by the only mandatory school-based drug detection approach ${ }^{43}$, generated conflicting results. Although immediate rates of drug detention were reduced, intentions for future involvement in drug use were heightened. 
Programmes that were effective in changing behaviours, attitudes or intentions relating to performance enhancing drugs were characterised by:

- Interventions conducted over longer periods (2-10 weeks) and comprising a number of teaching sessions rather than those delivered on a 'one shot' basis.

- Programmes that addressed a range of topics including drug and alcohol related issues, alternatives to drug use (nutrition, training methods) and media / peer pressure resistance.

- Increasing participant involvement and ownership in the programme either through peer lead teaching or homework / coursework assignments.

There are several limitations to the existing research. Firstly, whilst a number of studies successfully modified attitudes or intentions related to drug use, they were less effective in reducing drug use behaviours. Too few studies have conducted long-term follow-up to determine whether intervention effects persist over time and whether they translate into reduced drug usage. Secondly, all studies to-date have employed self-report questionnaires to gather data, without corroboration by other methods. Because the issues addressed in this research relate to illegal or taboo practices, or indeed social desirability favouring exaggeration, the validity of findings may be compromised due to under and over-reporting. Research in this field has primarily targeted college or university athletes, with programmes co-ordinated primarily within the athletic department. College and university athletes differ from other athletes in that they are subject not only to the pressures of sporting performance but also expectations regarding their academic achievement, which may create a unique set of circumstances surrounding the decision to engage in drug use. Accordingly, it is not appropriate to generalise the methods and findings of these studies to other settings and populations. Research has mostly been confined to prevention of anabolic steroid use, with less attention paid to other performance enhancing and recreational drugs, such as growth hormones, amphetamines or cocaine. 


\section{MODELS OF PERFORMANCE ENHANCING DRUG USE}

This review of literature has highlighted a significant limitation of the current body of knowledge - the application and empirical validation of doping models in sport is scant. Infact, at the time of writing, only two conceptual models were identified that attempt to provide a framework for understanding performance enhancing drug use and a brief description of the tenets of these models seems appropriate. The Drugs in Sport Deterrence Model (DSDM) ${ }^{119}$ is founded upon criminal deterrence theory and the Drug Compliance in Sport 29 framework emanates from a health promotion / injury prevention perspective, drawing upon behavioural science research on cognitive models, threat appeals and instrumental and normative approaches to guide their research. Both models attempt to theorise how athletes think about doping, in the hope that is will help guide and develop more efficacious anti-doping educational campaigns.

\subsection{The Drugs in Sport Deterrence Model (DSDM)}

The DSDM, presented in Figure 2, is a drug deterrence model for elite athletes. Its aim is to enhance psychologists' understanding of decision-making by elite athletes in relation to using performance enhancing drugs. This model draws upon Deterrence Theory ${ }^{93}$ which is a theoretical approach to understanding compliance with the law. DSDM comprises three elements: (1) costs of a decision to use, (2) the benefits associated with using, and (3) specific situational factors which may impact in some way on the cost-benefit analysis of using. The DSDM is consistent with the rational choice perspective which posits that individuals' behaviour is determined by a conscious and careful cost-benefit analysis of the likely consequences of a particular course of action. This has strong associations with Decision Balance Theory, which has strongly influenced many other areas of Public Health intervention planning. 


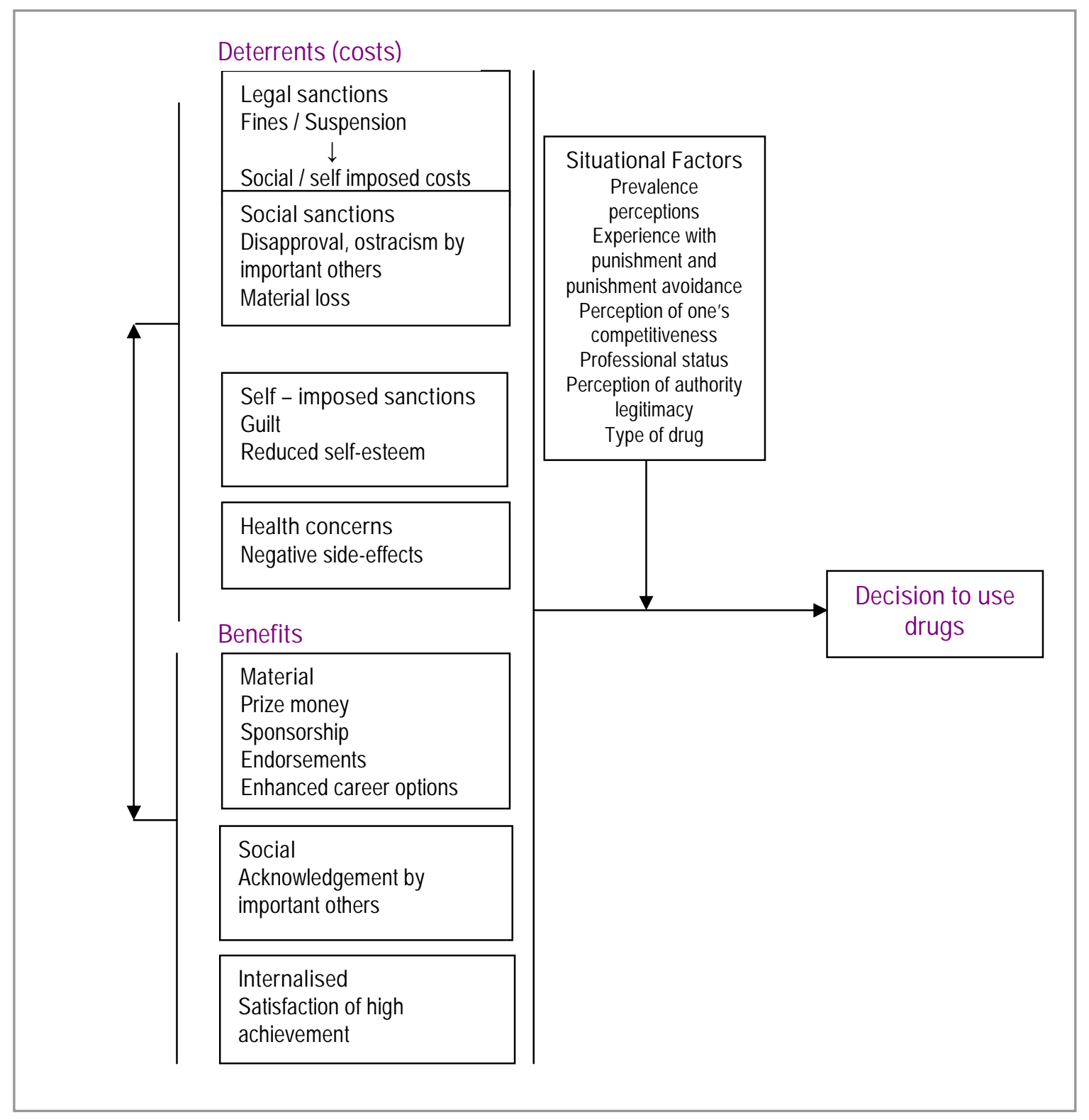

Figure 2. The Drugs in Sport Deterrence Model (DSDM) 119 


\subsection{Drug compliance in sport: A conceptual framework}

Donovan and colleagues ${ }^{29}$ have presented a conceptual framework which seeks to facilitate athlete compliance in relation to the use of performance enhancing drugs in sport (Figure 3). Funded by the Australian Sports Drug Agency (ASDA), researchers employed three behavioural science frameworks to produce the model, namely: social cognition models, threat (or fear) appeals, and instrumental and normative approaches. A grounded theory approach was taken, wherein literature relating to performance enhancing drug use was examined only after the model had been developed. The resulting model comprises six components believed to affect attitudes or intentions toward drug use: a) threat appraisal, b) benefit appraisal, c) personal morality, d) legitimacy, e) personality/self-esteem and f) reference group opinion. In addition, the affordability of drugs and their availability were two 'market' factors included in the model, based on the rationale that such factors may facilitate or inhibit the translation of attitudes and intentions into behaviour.

The model can be viewed as a weighted attribute model:

Drug use $=\sum\{$ W1 (threat), W2 (drug use benefits appraisal), W3 (personal morality), W4 (legitimacy of enforcement framework), W5 (reference groups' opinions), W6 (personality factors), W7 (affordability), W8 (availability)\}. 


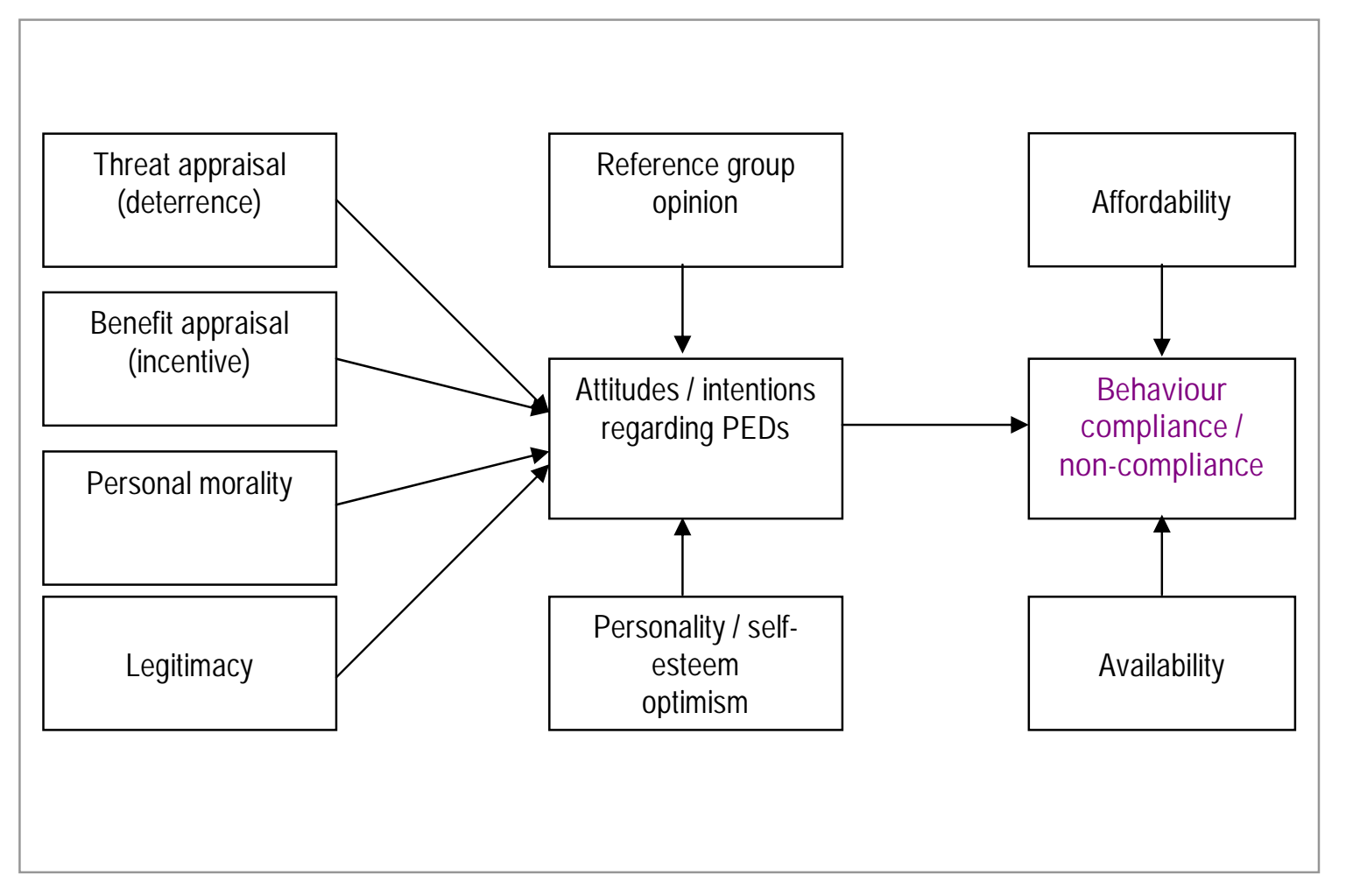

Figure 3. Drug compliance in sport conceptual framework 29

\subsection{Discussion}

\subsubsection{Model comparisons}

Despite the contrasting start points, the two models share a number of similarities. Firstly, both models frame the decision to use performance enhancing drugs as a rational, informed choice and apply the belief that attitudes and intentions are determinants of subsequent behaviour 2 . Currently, the application of psychological theories for understanding drug use in sport is limited 76. However, the potentially important role of psychosocial factors in the decision to engage in doping behaviour can be found in both models and such factors can sit under the heading of 'subjective norms', labelled by the attitude theorist, Ajzen (1985). For example, Donovan et al 29 refer to 'reference group opinion' as a key variable in the decision to use performance enhancing drugs, whilst Strelan and Boeckmann 119 include opinions and relationships with important others under the heading of 'social sanctions'. In both cases, the central concern is that the decision to 
use performance enhancing drugs is influenced by the salient beliefs and behaviours of others, such as fellow athletes, coaches, family or physicians.

The two models comprise mostly comparable components, essentially differing only in the manner in which the constructs are organised. Donovan et al 29 present 'personal morality' and 'reference group opinion' as key variables in the decision to use performance enhancing drugs in there own right, whereas Strelan and Boeckmann ${ }^{119}$ accommodate these constructs under headings of 'self-imposed sanctions' for 'personal morality' and 'social sanctions' in the case of 'reference group opinion'. Market factors (availability and affordability) and legitimacy as described by Donovan et al ${ }^{29}$ can be accommodated within the DSDM under the situational factors heading.

Differences between the two models derive primarily from the claims made by the authors with respect to the scope and operation of the models when applied practically. Strelan and Boeckmann ${ }^{119}$ are more cautious than Donovan et al 29 in their appraisal of the model. They specify that the DSDM is intended to improve understanding of performance enhancing drug use amongst elite athletes and that it is not intended to operate as a drug deterrence programme, rather as a starting point for further research and development of a more comprehensive model. Donovan et al ${ }^{29}$, by contrast, assert that their model is intended to be applied in drug prevention efforts and provides anti-doping agencies with a structured framework for strategic planning and implementing interventions. They also suggest that the model can be applied across all levels of sporting performance (although the relative importance and relevance of different variables will differ). Moreover, the authors assert that the model is flexible enough to be applied during different stages of the competition / training calendar, between different sports and between athletes at different stages in their career.

\subsubsection{Models in practice}

From a practical perspective, the model proposed by Donovan and colleagues ${ }^{29}$ may be easier to apply because each key construct is described explicitly. Therefore, measurement tools and intervention efforts can be developed specifically for each construct. Potentially important variables would need to be drawn out from the more general categories used in the DSDM. The 
flexibility offered within the DSDM - potentially important variables are grouped under broad headings - may allow researchers greater scope for innovation and identification of important new predictive constructs. However, as knowledge and understanding of performance enhancing drug use in sport grows, it may be that the Donovan et al ${ }^{29}$ model, with its clearly defined and specific constructs, may not readily accommodate new ideas and research findings.

Lucidi et al ${ }^{72}$, in their study on the determinants of the intention to use doping substances, drew core variables from the Theory of Planned Behaviour (attitudes, social norms, perceived behavioural control) ${ }^{5}$, but also added 'moral disengagement'. This construct is comparable to that described by Donovan et al ${ }^{29}$ as 'personal morality', which describes the internalisation of broad social values relating to fair play, courage and winning-related behaviour. For Lucidi et al., 'moral disengagement' was used to identify the level of detachment from such prevailing moral values. Theoretical propositions predicting intentions were supported across genders; the model accounted for $51 \%$ of criterion variance. Attitudes, followed by subjective norms, were the strongest predictors of intention to use doping substances. Moral disengagement and past use of protein supplements also influenced behavioural intention. These findings underline the need to develop more sophisticated and tailored interventions to support those athletes holding values that heighten risk for using performance-enhancing drugs and the need to develop empirically tested models is clear.

\subsubsection{Model development agenda}

Recently, a number of social science researchers from the University of New South Wales in Australia have offered useful and stimulating insights into future research agendas for the development of empirically driven models which best represent how athletes think about doping. The first novel way of approaching the issue of drugs in sport is from an economic model perspective. Research questions to be explored using this model include what incentives cause athletes to take performance enhancing drugs and what counter-incentives are most likely to be effective in preventing their drug use. Sharpe ${ }^{109}$ suggests that an equally valid question to test using this methodology is which drug prevention regime will most likely induce rational, selfreferenced individuals not to take drugs. 
O'Donnell, Mazanov and Huybers 84 presented a paper to the Social Science Methodology conference in Sydney, outlining their planned development of an empirical choice model of athletes' decisions to use performance enhancing substances or methods. Given the striking void of model development, testing and application in the field of drug use in sport, it should not be surprising to learn that the application of choice modelling to understanding athletes' performance enhancing drug use is also novel. Yet, the fields of marketing and economics have systematically applied this approach and numerous academic publications have emerged (for example, see ${ }^{55}$ ).

Currently, the model is in the very early stages of development; however, the research team has identified a number of emergent themes for follow-up investigation. The factors are indicative only, but include: a) Performance factors (competitiveness, success, fear of failure), b) Penalty factors (deterrent, stage of career), c) Health factors (side effects, pain/injury, weight control), d) Social factors (in/out group, social influence, modelling), e) Substance factors (type of drug, availability). Finally, potential covariates have been identified, which include emotional intelligence, risk seeking, attitude, overconfidence and social vulnerability. The next step in the programme is to empirically test the identified factors and covariates, which are simply theoretical constructs at present, in the context of drugs in sport. The same requirement also applies to the economic method.

There are many psychosocial theories that could be modelled in this domain and investigations may well be underway. Indeed, towards the end of December 2006, a paper entitled 'Why Drug Testing in Elite Sport Does Not Work: Perceptual Deterrence Theory and the Role of Personal Moral Beliefs' 118 was published. It was too late to include this study in the current review; however, its publication into the scientific community illustrates the dynamic nature of research. Furthermore, the relationship between the medicalisation of sport 132 and doping is a sociological perspective worthy of further investigation. Waddington argues that "if we wish to understand the use of performance enhancing drug use in sport then it is crucial that we understand the centrality of the relationship between elite level athletes and the practitioners of sports medicine (p.11). This discussion is framed within the context of a prevailing 'pill dependent cutlure' and the need to consider the issue of communities ${ }^{132}$ and the social context if we are to truly understanding doping in sport. 


\section{DRUGS AND VALUES: AN ETHICAL REFLECTION OF THE LITERATURE}

\subsection{Introduction}

The social science research that we have highlighted around the area of doping in sport has thrown up a great variety of approaches to practice and the ethical meaning that we attach to that practice. From the outset it is clear that there is very little sense of shared value or purpose amongst the participants and their related communities in a lot of the papers identified. The first impression is of ethical relativity, an acceptance that there are no absolute or global values that apply to all these different contexts. An ethical analysis of this material might take many forms depending on the school of philosophy and theology the ethicists belongs to, to say nothing of his or her innate bias. In order to avoid any sense of imposing ethical meaning upon the data we intend to make use of three reference points. The first is a framework for ethical decisionmaking. This will help to show us how the different groups and persons made their decisions. The second analytical tool is that of virtue ethics. The third ethical approach is that of moral psychology (Please see Appendix C for further detail).

\subsection{An ethical reflection of selected papers}

In the papers that examined the perceived effects of anabolic steroid use in bodybuilders and powerlifters, overall, the good effects of steroid use on psychological, physical and vocational functioning, and enhanced social recognition and acceptance was stressed. Interestingly, Schwerin and Corcoran 107 report that non-steroid users see users, as a group, as largely dysfunctional in these areas and unaware. Amidst all that, the drug users did not perceive that there were any negative effects of the drug use and psychological or physical dependence was minimised in terms of dependence on the improved body functioning. In ethical terms several things emerge in this area.

Firstly, the drug users did not show a clear grasp of the data about drug use. Their interpretation of this was entirely to do with themselves, with no awareness of the potential effect of their drug use on a wider culture. Secondly, this would suggest that perceptions of data were being dominated by a quite narrow view of moral meaning. For most participants this seems to be 
confirmed, with a stress on a libertarian and Unitarian view of ethics. The first, argues that any thing is acceptable so long as it does not affect others. The second argues that an action is good or bad dependent on the consequences. Hence, the participants largely conclude that the consequences of taking steroids are good for them and that they do not harm others. There is moral language being used here, and some photospheres, such as Peter Singer ${ }^{113}$, argue for a complete form of this approach. However, there is little attempt to justify this ethical base by the steroid users and far from looking at other views of morality their view is confirmed for them by peer usage, and thus by the moral community of which they are a part. Thirdly, the narrow ethical awareness and limited perception of the data would seem to indicate that at the base of their ethical meaning was attached to a conditional view of self worth- 'I am acceptable only if I have a good body image, perform well in sport etc.' A similar dynamic exists in alcohol addiction 124. Fourthly, with moral reflection sealed within the community, or subculture, there is little value conflict. Olrich and Ewing ${ }^{87}$, however, do report two cases of value conflict. In both instances, the participants speak of their behaviour conflicting with morals or principles. In neither case is that conflict articulated in detail. Significantly, the conflict does have strong affective power, with a continued sense of guilt being reported. This was clearly a sense of shame, a deep sense of wrong behaviour being 'exposed' to a wider community. The conflict is also attached to other communities outside the steroid user group. Hence, one user contrasts the way of life of his wider family and this points to a different set of values and to different behaviour that can achieve more satisfying acceptance. The effective moral challenge then in these cases seems to operate at the affective level and attached to personal links to other communities. Being a part of these other communities means that the person is often operating according to their ethical perspectives and standards when with them. For the most part however the two different ethical worlds are kept apart, until there is some personal encounter that crosses the two worlds, effecting shame and causing the person to be aware of value conflict and question to values previously held.

From this ethical base it is not surprising that there was little sense of responsibility or the negotiation of responsibility. The strong impression for most of the bodybuilders is that their responsibility was largely to themselves. Any change in this does not emerge until value conflict has occurred. Even with such a change it is not clear that responsibility is seen in a wider context, or who the person might be responsible to other than the self and this narrow ethical perspective 
is confirmed by Anshel ${ }^{11}$. He reports physical, psychological and social reasons for using performance enhancing drugs in elite athletes. The first set of reasons lead to improved performance. The second set would seem to indicate improvement of low self-esteem and with that an ethical perspective that is based on conditional worth. The third uses other athletes who take drugs as models, and thus justification. Ethical thinking here would seem to indicate stages three or four in Kohlberg's stages, where the individual looks to the peer group to determine values, and the individual takes little responsibility for thinking through his or her own position. In one sense responsibility from this is given to the other drug users who act as models- 'If they can do it why can't I'. Very quickly this kind of ethical thinking leads to ethical fallacies such as 'If I didn't use these drugs somebody else would and they would have an unfair advantage'. Such logic is fallacious precisely because it seeks to justify drug use without actually examining what is right or wrong about this practice beyond a narrow view.

Things start to become more murky, leading to apparent moral confusion and uncertainty when the issue of drug testing emerges ${ }^{77}$. At one level this points to a real debate about the ethics of drug testing. The Diane Modahl case in particular raises issues for elite athletes about the fairness of the procedures, confidence in the accuracy of the tests, and the intransigent attitudes of those responsible for the testing. The moral unacceptability was generally taken as read. The concern then was to avoid negative effects on the athletes undergoing testing. They accepted that responsibility for knowing about banned drugs was down to them, but report that they did not have full knowledge of the banned drugs or related penalties for use. There was still little sense of wider responsibilities to fellow athletes or other stakeholders. There was little sense of even who the stakeholders might be in the doping. The major concern for the wider communities only seemed to emerge in a cynical view about the way in which modern sport is financed and commerce driven, including the Olympics. There is, however, not reference to any of the positive values and purpose at the base of the Olympic movement, though this seems to be implied in the negative contrast with the business interests.

In this debate then there are strong echoes of the previous papers, with stress on a libertarian/utilitarian view of ethics. However, there is more complex ethical thinking with real questions about any ethical concerns actualised, through codes and disciplinary procedures. This 
debate was both about fairness at a cognitive level but also about the attitude of the governing bodies, at an affective level. In one sense this represents a very important debate around value conflicts and this is an important example of an ongoing critical learning process. The debate, however, needs to be deepened and developed, as is noted by participants in the McCardle study, some of who wanted more justification for the punishment of drug users and not the simplistic fall back on trying to eradicate 'cheating'. The participants would clearly have liked a more complex moral framework and future research endeavours must begin to acknowledge this need.

Other work on drug testing 23 notes that participants felt shame at having to provide samples for drug testing. They wanted to find ways of humanising the experience, yet at the same time they were able to use the possibility of a test as an acceptable basis for refusing drugs from their peers. This is another example of answering a moral challenge within a community with a moral reference from outside it. This is not a personal link, but rather involves the standards of the sporting community mediated through the testing practice and behind that is the core value of transparency.

One paper reports strong value conflicts where the values of other community members become more explicit ${ }^{28}$. In this article, college athletes show a broader community of practice relating to Higher Education (HE). Moreover, this is not a simple utilitarian view of $\mathrm{HE}$, but one that espouses justice and equity. This in turn is reinforced by peer group and coach pressure. The collegiate ethical identity also has some sense of pride in representing the college, and therefore, by implication, upholding the values. In the light of such a value framework random tests can be justified as fair.

An interesting line of inquiry from an ethical perspective was the hypothetical comparisons of elite athletes who have taken drugs as compared to those who have not by the general public. Grove and Paccagnella's research ${ }^{50}$ suggests that athletes who have taken drugs are viewed as possessing negative personality traits compared to drug free athletes. The authors speculate that this might be partly the effect of 'tall poppy syndrome' the concern to bring down those who have succeeded. Drawing on other studies the authors suggest that behind this psychological dynamic 
may be some very explicit moral values. Firstly, they note the 'just world effect'. This provides a broad view of justice in life - people get what they deserve. The effect may not be quite so strong if the elite sport person has already been loved by their public. Secondly, fuelled by this view of justice as merit is the view from those outside sport that the sports community demands the highest standards around fairness, conformity, fair play and an ethic of success through personal effort and hard work. There may also be some sense of an ethic of sacrifice in this view. Thirdly, and critically, elite sportspersons are the object of intense identification amongst the public, with a genuine admiration for their dedication. Such identification may well lead to a sense of betrayal once conflicting behaviour is exhibited. It is perhaps not surprising that in the related paper 89 the same authors note that athletes who have fallen from grace are viewed more negatively than criminal offenders.

Isaari and Coombs 56 and Corbin et al 25 have attempted to examine different ethical perspectives and contexts. For example, Isaari and Coombs ${ }^{56}$ look at gender differences in terms of drug taking and drug testing. In broad terms the results reinforce gender stereotypes. However, they also seem to reinforce the view held by Gilligan 38 in her debate with Kohlberg on moral development. She characterised Kohlberg's view as focused on individualist problem solving with a stress on freedom and rights. The contrasting feminist perspective focuses on community and cooperative activity. Hence, women in the survey were seen to be more socialised, more aware of belonging to a broader community and less concerned with drug testing as a violation of rights. High School provides the context for the paper by Corbin et al 25 and this study corroborates the findings of Isaari and Coombs in terms of gender, with females appearing more aware of the issues involved in doping. This study highlights significant differences between males and females in developmental terms. The boys surveyed showed an increased openness to drugs as they progress through the school. This may be because they come across more drug use and peer pressure. The girls show a low rate of drug use in grade 8 and 9 , an increase in drug use in year 10 and then in year 11 and 12 a further low rate. Moreover, in grade 11 and 12 the girls were less likely to consider steroid use even if it guaranteed success in athletics. Once again this raises questions ripe for research. As Fowler 35 notes value conflict often emerges around moments of personal development leading to disenchantment with old values, disorientation around purpose and values, and disidentification (uncertainty about 
identity). Teenagers and beyond clearly experience developmental crises at cognitive, affective and somatic levels and there could be many different values systems competing to be heard. It would seem important to find out more about the moral world of the various target groups in relation to drugs in sport and the wider community.

Laure, Thouvenin and Lecerf 68 focuses on one stakeholder who has as much to gain or lose as the athlete, the coach. As highlighted in the Dubin report ${ }^{30}$, the coach plays a very important part in helping to develop and motivate the athlete in general. It seems that some coaches actually encourage the athlete to explore performance enhancing drugs, even going as far as suggesting doctors who could be approached. Laure and colleagues provide data, and refer to more detailed data, noting that their athletes ask one out of six coaches about drug use over a period of three months or more. This would seem to indicate that drug use is only a small part of the coachathlete conversation and Laure et al suggest that this accounts for only a minority of coaches taking a militant stance on drug use and silence from the majority. However, one out of ten coaches reported that the athlete did report attempts to incite them to take drugs. These reports note that half those inciting them were either fellow competitors or coaches themselves. In addition, some $5 \%$ of the coaches interviewed revealed that they also took performanceenhancing drugs.

From an ethical perspective, an insightful finding emerged with most coaches reporting that when faced with doping questions from their athletes they did not have a very effective argument to deter them from use. The majority stressed simply the potential harmful effects of the drugs and Laure et al note that this consequentialist argument is not often successful in deterring athletes. The writers reach the critical conclusion that the majority of coaches have not actually worked through how to motivate their athletes to stay clean. Laure et al note that the coaches report very few 'actions' in trying to get any moral argument across to the athletes.

There are a number of ethical questions in relation to the findings of Laure and colleagues. Firstly, what is the professional identity of the coach? Is there a professional body, with a code of practice? We have noted above that in this area and in ethics in general the most effective motivation to work against drugs comes from the well-formed ethos or codes of another 
community- be that school of family. The professions within sport are a very clear example of a community with a moral identity. Secondly, the professional context for the code would also raise the questions about responsibility. Who is the coach responsible to? This common response from other professions is complex 101 involving responsibility owed to:

- clients (in this case the athlete). How is that worked out? Has it been set out by the professional body?

- co-professionals. Typically, professionals will speak of maintaining the integrity of the profession itself. If one professional does no fulfil broader responsibilities then this will not only make if hard for him or her to be trusted, it will also make it harder for the public to trust the profession as a whole.

- society as whole, including future generations. This begins to signal a very big responsibility that at first is very hard to focus. The engineer, for example, can focus on his handiwork and the effects of any disaster. How does the coach effect responsibility to society? This might be partly through how the contributes beyond his or her professional community to the community of his sport as a whole, or indeed sport itself. In this sense, the coach is contributing to both the values and virtues of sport and to the very character of that sport. In turn, that asks questions of the effect of that sport on society.

All this in turn raises questions about the coach/athlete relationship and its moral base. Do the coach and athlete develop a contract of some kind, and does this contract in any way embody key values or virtues? Elsewhere Robinson has argued 100 that in the therapeutic context, contract is an essential part of developing shared values and practice.

\subsection{Discussion.}

The selected papers outlined in this section reveal some ethical reflection and decision making frameworks. However, these show, on the whole, quite limited awareness of the process and content of ethics in this area. The result is that there is little common ground from which to challenge the athlete other than through concern for self interest around the harm of drugs. Of course, these results may have been what we might expect if we pursue research from a mainly social science perspective. The problem then, however, is that most of the recommendations about how to deal with the problem are couched in terms of problem solving. For instance, if high 
school boys are coming across drugs through working in the gym then we need to ensure that gyms are properly policed. This does not begin to address the underlying question of ethical meaning and how this might have to be engaged more effectively.

What debate there is, around conflict, or dynamics in the relationships with authorities, is very important but runs the danger of staying at the level of opinions. Faced by the pressure of peer groups it would seem important for the development of what Mustakova-Possardt 81 refers to as a critical moral consciousness, akin to Ricoeur's critical hermeneutic ${ }^{99}$. This looks to enabling moral development that empowers the athlete to reflect critically on ethical values held by the self and others, and to develop responsibility for those values. In the absence of a clearly worked out responsibility this leaves athletes relying on negative values to answer incitement to drug use- 'I can't take the drug because I am subject to random tests'. This tells us nothing about why taking drugs might be wrong.

On balance, developing the motivation to be ethical is not about developing knee jerk reactions to codes of ethics or practice ${ }^{81}$. It involves the person developing their own ethical identity such that their values tie in with and affirm their decision-making (Robinson 2007). Hence, the person should feel good about themselves in standing up to peer pressure and challenging practice that they find unacceptable. Ethical motivation in all this can involve self-interest. Most of the moral motivation in the papers reviewed seems to be around this perspective. Self-interest is a perfectly reasonable motivation to be ethical. However, in many of the papers reviewed there is a conflicting view of self-interest; avoiding harm to the self from the effects of doping against doing good for the self in terms of maximising performance. Secondly, mutual interest is a form of ethical motivation. This has greater strength for moral motivation in that it identifies the shared interest. This provides a shared moral meaning and a shared view of practice that reinforces the accepted behaviour. Finally, transcendent interest looks at interest in a group or value beyond the person of narrow community. This sees the persons or group as stakeholders within the wider community who have shared responsibility for that community, and naturally moves into the negotiation of responsibilities. 
Having all of these improves motivation, particularly if they are connected to the community to which the agent belongs, and hence to the identity of the agent. Much of this goes back to the Aristotelian view of virtue ethics. In this, the moral agent reflects on the purpose (telos) of his role, or community, and from that purpose discovers the embodied meaning in practice. There is little sign of this practical wisdom being articulated in the papers under consideration.

To develop this there needs to be articulation and testing of ethical thinking in this area, including any different perspectives. This means providing space for critical conversation. There also needs to be much wider reflection on stakeholders and the role and responsibility of sportspersons in relation to them. Finally, it is of interest that nowhere was there the articulation of ethical values that go beyond the limited perspective of profession or particular interest area. If one takes the work of Parry, McNamee and others, there is strong argument around the idea of a community of practice that stresses excellence, mutuality, fairness and so on, and that the ethical meaning of this is embedded in the idea of sport itself. 


\section{RECOMMENDATIONS FOR FUTURE RESEARCH}

On balance, published research examining attitudes, precipitating factors and education initiatives in relation to doping in sport is limited and requires systematic expansion. The scientific literature on prevalence of drug use continues to dominate and grow. However, future research needs to move beyond prevalence statistics and descriptive analysis by employing theoretical frameworks and more sophisticated methodologies to explore the decision making process involved in doping. In short, the scientific community needs to establish an evidence base built upon studies that represent the higher echelons of the hierarchy of evidence. Only then can interventions be appropriately developed and evaluated. However, such developments must be carefully monitored, systematic, rigorous and theoretically driven if this field is to progress. Furthermore, adequate funding must be made available to support the challenging task that lies ahead conducting quality social science research requires investment. The detail below does not represent an encompassing list of the potential directions in the field. However, it points to some key areas for consideration in relation to precipitating factors, attitudes and intervention research, in the immediate future.

\subsection{Research methodology}

- Future investigations must adopt designs that are higher in the research hierarchy. With a few notable exceptions in the education/intervention field of study, level III research designs dominate the literature. To facilitate progression and the development of models which will inform education prevention efforts and best practice, research must move beyond cross-sectional research towards experimental and controlled studies (Levels I and II). Such designs will enable the examination of causality.

- A systematic approach to research development needs to take place which builds upon and extends previous findings in the field. Adopting a Behavioural Epidemiological Framework would assist in developing a much needed 'feed forward' approach.

- At present, with the exception of only a handful of projects, this research field suffers from 'one hit' approaches and lacks a body of academics engaging in scientific debate. Such debate should be encouraged and supported through the development of forums and 
networking opportunities. Increased publication outputs from doping organisations will also help to share information and evidence from an applied practice.

- Research must approach the study of doping in sport from a theoretical perspective. This is justified by the wide diversity of potential risk factors for current and future use of prescribed drugs and attitudes towards doping in sport.

- These models should reflect the expansive and possibly sequential nature of the respective precipitating and attitudinal factors.

- There are parallels for this development in other areas of health-related research. Approaches such as Psychoneuroimmunology and Socio-cultural-biological perspectives are now gaining ground in disease prevention and management.

- Identifying the interactive effects of a range of factors - ranging contextual, demographic, behavioural, personality to sporting - seems justified.

- This will help to better understand any pathway mechanisms and pathways - into and out of drug use.

- Trials are needed to assess the predictive specificity and sensitivity of factors identified across research designs.

- Researchers are encouraged to employ innovative and rigorous methods of data collection. This is especially important given the sensitive nature of the behaviour of interest.

- Longitudinal research, which monitors the population group over an extended period of follow-up, may contribute to a better understanding of the doping process and aid in the development of doping prevention initiatives.

- Quantitative methodologies dominate the literature to date and therefore future research employing qualitative methodologies is encouraged. In-depth qualitative research designs may be especially suited to understanding the doping dilemma and to identifying the span of understanding of the range of emerging factors that precipitate drug use

- If questionnaires are to be administered in research designs, they must be subject to prior psychometric testing. Therefore, future research must develop instruments that are fit for purpose and psychometrically robust.

- In terms of attitude-behaviour research, given the sensitive nature of some of the research questions posed, future studies should consider the use of methods that 
allow for implicit attitude measurement rather than solely relying on explicit attitudes measurement, which can be subject to self-presentation bias.

- The motives and precipitating factors underlying the use of performance enhancing substance use are unlikely to be monolithic. Therefore, researchers are encouraged to adopt a holistic approach to studying this complex issue - drawing upon fields such as sociology, psychology and ethics.

\subsection{Target groups}

- Research requires considerable globalisation, beyond the United States. At present, generalisation is not possible and a more encompassing cultural perspective is required. Therefore, multinational studies, employing the same research methodologies are encouraged.

- All groups reviewed in this document require further systematic investigation. However, groups notably absent from the target groups identified were females, ethnic groups and athletes that have committed a doping violation.

- Research should assess risk factors, attitudes and intervention efforts in relation to a range of performance enhancing drugs. The majority of existing literature focuses upon anabolic steroid use.

\subsection{Education}

- Embed interventions within a theoretical framework or model. Consider adopting more eclectic theoretical perspectives to fully integrate more effectively a wide range of variables that operate within mechanisms of drug initiation (including maintenance) as well as drug rejection.

- Research must strive to develop appropriate intervention strategies that are based upon a sound evidence base.

- Explore prevention strategies for use of a range of performance enhancing and recreational drugs in athletes.

- Conduct long term follow-up of intervention effects to assess their persistence over time and determine whether programmes are being effective in reducing actual drug use. 
- Identify and support those individuals (or groups) who may be vulnerable to countereffects of well-intentioned approaches.

- National Anti-doping organisations, charged with delivering mass anti-doping education programmes, are strongly encouraged to evaluate their education programmes and publish their findings in the scientific literature.

- To facilitate this challenging task to be undertaken, NADOs are encouraged to work with academics in the field and collaborate with research institutions in order to develop appropriate evaluation tools. 


\section{REFERENCES:}

1. Hierarchy of evidence and grading of recommendations. Thorax. 59:13i-14, 2004.

2. Ajzen, I. From intentions to actions: A theory of planned behavior. In: Action-control: From cognition to behavior. J. Kuhl and J. Beckman (Eds.) Heidelberg: Springer, 1985, pp. 11-39.

3. Ajzen, I. Nature and operation of attitudes. Annual Review Psychology. 52:27-58, 2001.

4. Ajzen, I. and M. Fishbein. Understanding attitudes and predicting social behavior. Englewood Cliffs NJ: Prentice-Hall., 1980

5. Ajzen, I. and T. Madden. Prediction of goal-directed behavior: Attitudes, intentions, and perceived behavioral control. Journal of Experimental Social Psychology. 22:453-474, 1986.

6. Alaranta, A., H. Alaranta, J. Holmila, P. Palmu, K. Pietila, and I. Helenius. Self-reported attitudes of elite athletes towards doping: differences between type of sport. International Journal of Sports Medicine, 2006.

7. Albrecht, R. R., W. A. Anderson, C. A. McGrew, D. B. McKeag, and D. O. Hough. NCAA institutionally based drug testing: Do our athletes know the rules of this game. Medicine and Science in Sports and Exercise. 24:242-246, 1992.

8. Ama, P. F., B. Betnga, V. J. Ama Moor, and J. P. Kamga. Football and doping: Study of African amateur footballers. British Journal of Sports Medicine. 37:307-310, 2003.

9. Anderson, W. A., R. R. Albrecht, D. B. McKeag, D. O. Hough, and C. A. McGrew. A national survey of alcohol and drug use by college athletes. Physician and Sportsmedicine. 19:91-94, 1991.

10. Anshel, M. H. Cognitive behavioural stratagies for combating drug abuse in sport: Implications for coaches and sport psychology consultants. The Sport Psychologist. 5:152-166, 1991.

11. Anshel, M. H. A survey of elite athletes on the perceived causes of using banned drugs in sport. Journal of Sports Behaviour. 14:283-307, 1991.

12. Anshel, M. H. and K. G. Russell. Examining athletes' attitudes toward using anabolic steroids and their knowledge of the possible effects. Journal of Drug Education. 27:121-145, 1997.

13. Ardito, F., P. Goldstein, M. Bahrke, and T. Sattler. Anabolic steroid use: Prevention and education. International Journal of Drug Policy. 5:27-33, 1994.

14. Beauchamp, T. and J. Childress. Principles of Biomedical Ethics. Oxford: Oxford University Press, 1989

15. Bents, R. T., E. T. Powell, and J. M. Tokish. Ephedrine and pseudoephedrine use in college hockey players. Current Sports Medicine Report. 3:243-245, 2004.

16. Blouin, A. G. and G. S. Goldfield. Body image and steroid use in male bodybuilders. International Journal of Eating Disorders. 18:159-165, 1995.

17. Brower, K. J., F. C. Blow, and E. M. Hill. Risk factors for anabolic-androgenic steroid use in men. Journal of Psychiatric Research. 28:369-380, 1994.

18. Brower, K. J., F. C. Blow, J. P. Young, and E. M. Hill. Symptoms and correlates of anabolic androgenic steroid dependence. British Journal of Addiction. 86:759-768, 1991.

19. Burnett, K. F. and M. E. Kleiman. Psychological characteristics of adolscent steroid users. Adolescence. 29:81-89, 1994.

20. Carney, M. D. and K. J. Corcoran. Expectations for physical and non-physical effects from anabolic steroid use. In: Annual Meeting of the Eastern Psychological Association Philadelphia, PA, 1990.

21. Chester, N., T. Reilly, and D. R. Mottram. Over the counter drug use amongst athletes and nonathletes. Journal of Sports Medicine and Physical Fitness. 43:111-118, 2003.

22. Chng, C. L. and A. Moore. A study of steroid use among athletes: Knowledge, attitude and use. Health Education. 21:12-17, 1990.

23. Coombs, R. H. and C. J. Coombs. The impact of drug testing on the morale and well being of mandatory participants. International Journal of Addictions. 26:981-992, 1991.

24. Coombs, R. H. and F. J. Ryan. Drug testing effectiveness in identifying and preventing drug use. American Journal of Drug and Alcohol Abuse. 16:173-184, 1990.

25. Corbin, C. B., S. A. Feyrer-Melk, C. Phelps, and L. Lewis. Anabolic steroids: A study of high school athletes. Pediatric Exercise Science. 6:149-158, 1994.

26. Curry, L. A. and D. F. Wagman. Qualitative description of the prevalence and use of anabolic androgenic steroids by United States powerlifters. Perceptual Motor skills. 88:224-233, 1999. 
27. Diacin, M. Perceptions of male intercolegiate athletes on performance enhancement substances in sport. Bowling Green University, Bowling Green, 1999.

28. Diacin, M. J., J. B. Parks, and P. C. Allison. Voices of male athletes on drug use, drug testing, and the existing order in intercollegiate athletics. Journal of Sports Behaviour. 26:1-16, 2003.

29. Donovan, R. J., G. Egger, V. Kapernick, and J. Mendoza. A conceptual framework for achieving performance enhancing drug compliance in sport. Sports Medicine. 32:269-284, 2002.

30. Dubin, C. Commission of inquiry into the use of drugs and banned practices intended to increase athletic performance. Ottawa, ON, 1990.

31. Elliot, D. L., E. L. Moe, L. Goldberg, C. A. DeFrancesco, M. B. Durham, and H. Hix-Small. Definition and outcome of a curriculum to prevent disordered eating and body-shaping drug use. Journal of School Health. 76:67-73, 2006.

32. Evans, M., Weinberg, R. Jackson, A. Psychological factors related to drug use in college athletes. The Sport Psychologist. 6:24-41, 1992.

33. Finch, J. and J. Mason. Negotiating Family Responsibilities. London: Routledge, 1993

34. Fjeldheim, T. B. Sports instructors and sports leaders: Attitudes toward doping in sports. Collegium Anthropoligicum. 16:343-348, 1992.

35. Fowler, J. Faithful Change. Nashville: Abingdon, 1996

36. Fritz, M. S., D. P. MacKinnon, J. Williams, L. Goldberg, E. L. Moe, and D. L. Elliot. Analysis of baseline by treatment interactions in a drug prevention and health promotion program for high school male athletes. Addictive Behaviours. 30:1001-1005, 2005.

37. Fung, L. and Y. Yuan. Performance enhancement drugs: Knowledge, attitude and intended behavior amond community coaches in Hong Kong. The Sport Journal 9, 2006.

38. Gilligan, C. In a different voice. In: The Future of Difference. H. Eisenstein and A. Jardine (Eds.) New Brunswick, NJ: Rutgers University Press, 1985, pp. 274-317.

39. Goldberg, L., R. Bents, E. Bosworth, L. Trevsian, and D. L. Elliot. Anabolic steroid education and adolescents: Do scare tactics work? Pediatrics. 87:283-286, 1991.

40. Goldberg, L., E. E. Bosworth, R. T. Bents, and L. Trevisan. Effect of an anabolic steroid education program on knowledge and attitudes of high school football players. Journal of Adolescent Health Care. 11:210-214, 1990.

41. Goldberg, L., D. Elliot, G. Clarke, D. MacKinnon, L. Zoref, E. Moe, C. Green, and S. L. Wolf. The Adolescents Training and Learning to Avoid Steroids (ATLAS) prevention programme. Background and results of a model intervention. Archives of Pediatric and Adolescent Medicine. 150:713-721, 1996.

42. Goldberg, L., D. Elliot, G. N. Clarke, D. P. MacKinnon, E. Moe, L. Zoref, C. Green, S. L. Wolf, E. Greffrath, D. J. Miller, and A. Lapin. Effects of a multidimensional anabolic steroid prevention intervention. The Adolescents Training and Learning to Avoid Steroids (ATLAS) Program. Journal of the American Medical Association. 276:1555-1562, 1996.

43. Goldberg, L., D. Elliot, D. MacKinnon, E. Moe, K. S. Kuehl, L. Nohre, and C. M. Lockwood. Drug testing athletes to prevent substance abuse: Background and pilot study results of the SATURN (student athlete testing using random notification) study. Journal of Adolescent Health. 32:16-26, 2003.

44. Goldberg, L., D. P. MacKinnon, D. L. Elliot, E. Moc, G. Clarke, and L. Cheong. The Adolescents Training and Learning to Avoid Steroids (ATLAS) program. Preventing drug use and promoting health behaviours. Archives of Pediatric and Adolescent Medicine. 154:332-338, 2000.

45. Gray, G. R. and R. J. Schoof. Drug testing collegiate student athletes: Opinions of athletes and non-athletes. Journal of Legal Aspects of Sport. 3:51-58, 1993.

46. Greenway, P. and M. Greenway. General practitioner knowledge of prohibited substances in sport. British Journal of Sports Medicine. 31:129-131, 1997.

47. Grossman, S. J. Apple: description and evaluation of a substance abuse education and prevention programme for collegiate athletics. Journal of Primary Prevention. 20:51-59, 1999.

48. Grossman, S. J. and J. H. Gieck. Model alcohol and other drug peer education program for student athletes. Journal of Sport Rehabilitation. 1:337-349, 1992.

49. Grossman, S. J., J. H. Gieck, A. Freedman, and W. L. Fang. The athletic prevention programming and leadership education (APPLE) model: Developing substance abuse prevention programs. Journal of Athletic Training. 28:137-144, 1993. 
50. Grove, J. R. and M. Paccagnella. Tall poppies in sport: Attitudes and ascribed personality traits. Australian Psychologist. 30:88-91, 1995.

51. Gupta, L. and B. Towler. General practitioners' views and knowledge about anabolic steroid use: Survey of GPs in a high prevalence area. Drug and Alcohol Review. 16:373-379, 1997.

52. Haddock, G. and M. P. Zanna. Cognition, affect and the prediction of social attitudes. European Review of Social Psychology. 10:75-100, 1999.

53. Hallaghan, J. B., L. F. Hallaghan, and M. B. Snyder. Anabolic androgenic steroid use by athletes. New England Journal of Medicine. 321:1042-1045, 1989.

54. Hamilton, L. S. and R. W. Stone. Student attitudes toward drug testing of college athletes. Physical Educator. 47:33-36, 1990.

55. Huybers, T. Domestic tourism destination choices - A choice modelling analysis. International Journal of Tourism Research. 5:445-459, 2003.

56. Issari, P. and R. H. Coombs. Women, drug use and drug testing. Journal of Sport and Social Issues. 22:153-169, 1998.

57. Kanayama, G., S. Barry, J. I. Hudson, and H. G. Pope, Jr. Body image and attitudes toward male roles in anabolic-androgenic steroid users. American Journal of Psychiatry. 163:697-703, 2006.

58. Kanayama, G., H. G. Pope, G. Cohane, and J. I. Hudson. Risk factors for anabolic-androgenic steroid use among weightlifters. Drug and Alcohol Dependence. 71:77-86, 2003.

59. Kersey, R. Anabolic-androgenic steroid use by private health club/gym athletes. Journal of Strength and Conditioning Research. 7:118-126, 1993.

60. Kersey, R. Anabolic androgenic steroid use among California community college student-athletes. Journal of Athletic Training. 31:237-241, 1996.

61. King, N. D. Drugs in Sport: The developent of an instrument to determine the knowledge, behaviour, and attitudes of college athletes about sport-performance drugs and sport-coping drugs. University of Kansas, Lawrence, Kansas, 1991.

62. Kohlberg, L. Essays in Moral Development. San Francisco: Harper and Row, 1984

63. Laure, P. and C. Binsinger. Adolescent athletes and the demand and supply of drugs to improve their performance. Journal of Sports Science and Medicine. 4:272-277, 2005.

64. Laure, P., C. Binsinger, and T. Lecerf. General practitioners and doping in sport: Attitudes and experience. British Journal of Sports Medicine. 37:335-338, 2003.

65. Laure, P. and A. Kriebitzsch-Lejeune. Retail pharmacists and doping in sports: Knowledge and attitudes. A national survey in France. Science and Sports. 15:141-146, 2000.

66. Laure, P., T. Lecerf, A. Friser, and C. Binsinger. Drugs, recreational drug use and attitudes towards doping of high school athletes. International Journal of Sports Medicine. 25:133-138, 2004.

67. Laure, P. and H. Reinsberger. Doping and high-level endurance walkers. Knowledge and representation of a prohibited practice. Journal of Sports Medicine and Physical Fitness. 35:228$231,1995$.

68. Laure, P., F. Thouvenin, and T. Lecerf. Attitudes of coaches toward doping. Journal of Sports Medicine and Physical Fitness. 41:132-136, 2001.

69. Lindstrom, M., A. L. Nilsson, P. L. Katzman, L. Janzon, and J. F. Dymling. Use of anabolic androgenic steroids among bodybuilders- frequency and attitudes. Journal of Internal Medicine. 227:407-411, 1990.

70. Lloyd Jones, M. Application of systematic review methods to qualitative research: Practical issues. Journal of Advanced Nursing. 48:271-278, 2004.

71. Lorente, F. O., Peretti-Watel, P., Grelot, L. Cannabis use to enhance sportive and non-sportive performance among French sports students. Addictive Behaviours. 7:1382-1391, 2005.

72. Lucidi, F., C. Grano, L. Leone, C. Lombardo, and C. Pesce. Determinants of the intention to use doping substances: An empirical contribution in a sample of Italian adolescents. International Journal of Sport Psychology. 35:133-148, 2004.

73. MacKinnon, D. P., L. Goldberg, G. N. Clarke, D. L. Elliot, J. Cheong, A. Lapin, E. L. Moe, and J. L. Krul. Mediating mechanisms in a program to reduce intentions to use anabolic steroids and improve exercise self efficacy and dietary behaviour. Prevention Science. 2:15-28, 2001.

74. Maharaj, V. R., T. Dookie, S. Mohammed, S. Ince, B. L. Marsang, N. Rambocas, M. Chin, L. McDougall, and S. Teelucksingh. Knowledge, attitudes and practices of anabolic steroid usage among gym users in Trinidad. West Indian Medical Journal. 49:55-58, 2000. 
75. Mazanov, J. Measuring athletes attitudes towards drugs in sport. In: ACSPRI Social Science Methodology Conference. The University of Sydney, Sydney, Australia, 2006.

76. Mazanov, J., T. O'Donnell, and A. Batley. Psychology and Drugs in Sport: The annoyed, the inspired and the road ahead. The Sporting Mind. 5:3-8, 2006.

77. McCardle, D. Elite athletes' perceptions of the use and regulation of performance enhancing drugs in the United Kingdom. Journal of Legal Aspects of Sport. 9:43-51, 1999.

78. Melia, P., A. Pipe, and L. Greenberg. The use of anabolic androgenic steroids by canadian students. Clinical Journal of Sport Medicine. 6:9-14, 1996.

79. Miller, K. E., G. M. Barnes, D. Sabo, M. J. Melnick, and M. P. Farrell. A comparison of health risk behaviour in adolescent users of anabolic androgenic steroids, by gender and athlete status. Sociology of Sport Journal. 19:385-402, 2002.

80. Monaghan, L. F. Vocabularies of motive for illicit steroid use among bodybuilders. Social Science and Medicine. 55:695-708, 2002.

81. Mustakova-Possardt, E. Education for Critical Moral Consciousness. Journal of Moral Education. 33:1-19., 2004.

82. Naylor, A. H., D. Gardner, and L. Zaichkowsky. Drug use patterns among high school athletes and non-athletes. Adolescence. 36:627-639, 2001.

83. NetherlandsCentreforDopingAffairs. Three anti-doping studies from the NeCeDo: Education, gaps and anti-doping in intellectual sports. Netherlands: Netherlands Centre for Doping Affairs, 1997

84. O'Donnell, T., J. Mazanov, and T. Huybers. Towards a choice model of athletes' decision to use performance enhancing substances or methods: Factors and covariates. In: ACSPRI Social Science Methodology Conference. The University of Sydney, Sydney, Australia, 2006.

85. Ohaeri, J. U., E. Ikpeme, P. U. Ikwuagwu, A. Zamani, and O. A. Odejide. Use and awareness of effects of anabolic steroids and psychoactive substances among a cohort of Nigerian professional sports men and women. Human Psychopharmacology. 8:429-432, 1993.

86. Olrich, T. W. Perceptions of benefits and losses associated with the use and discontinuance of anabolic-androgenic steroids among male bodybuilders. Journal of Personal and Interpersonal Loss. 4:231-242, 1999.

87. Olrich, T. W. and M. E. Ewing. Life on steroids: Bodybuilders describe their perceptions of the anabolic androgenic steroid use period. The Sport Psychologist. 13:299-312, 1999.

88. Ozdemir, L., N. Nur, I. Bagcivan, O. Bulut, H. Sumer, and G. Tezeren. Doping and Performance Enhancing Drug Use in Athletes Living in Sivas, Mid-Anatolia: A Brief Report. Journal of Sports Science and Medicine. 4:248-252, 2005.

89. Paccagnella, M. and J. R. Grove. Drugs, sex and crime in sport: An Australian perspective. Journal of Sport and Social Issues. 21:179-188, 1997.

90. Pan, D. W., Baker, J.A. Perceptual mapping of banned substances in athletics. Journal of Sport and Social Issues. 22:170-182, 1998.

91. Panagiotis, G., D. Ourania, F. Christos, and P. S. Jannis. Knowledge on and attitudes of doping in sport, of young trainees in internal and general-familial medicine. Pharmacologyonline. 2:1-5, 2006.

92. Papadopoulos, F. C., I. Skalkidis, J. Parkkari, and E. Petridou. Doping use among tertiary education students in six developed countries. European Journal of Epidemiology. 21:307-313, 2006.

93. Paternoster, R. The deterrent effect of the perceived certainty and severity of punishment: A review of the evidence and issues. Justice Quarterely. 4:173-217, 1987.

94. Peretti-Watel, P., V. Guagliardo, P. Verger, P. Mignon, J. Pruvost, and Y. Obadia. Attitudes toward doping and recreational drug use among French elite student athletes. Sociology of Sport Journal. 21:1-17, 2004.

95. Perry, H., A. H. Evans, and B. N. C. Littlepage. Anabolic steroids: What do GPs think? International Journal of Drug Policy. 5:15-17, 1994.

96. Peters, R. J., L. F. Adams, J. B. Barnes, L. A. Hines, D. E. Jones, K. M. Krebs, and S. H. Kelder. Beliefs and social norms about ephedra onset and perceived addiction among college male and female athletes. Substance Use and Misuse. 40:125-135, 2005. 
97. Petroczi, A. and T. Nepusz. The effect of self-impression management in social sceince doping research. In: Conference on Ethics and Social Science Research in Anti-Doping. Larnaca, Cyprus., 2006.

98. Pope, H. G., G. Kanayama, M. Lonescu-Pioggia, and J. I. Hudson. Anabolic steroid users' attitudes towards physicians. Addiction. 99:1189-1194, 1999.

99. Ricoeur, P. Ethics and Culture: Habermas and Gademar in Dialogue. Philosophy Today. 17:153$165,1987$.

100. Robinson, S. Agape, Moral Meaning and Pastoral Counselling. Cardifff: Aureus, 2001

101. Robinson, S., R. Dixon, and C. Preece. Engineering Business and Professional Ethics. London: Heinneman Butterworth, 2007

102. Salva, P. S. and G. E. Bacon. Anabolic steroids: Interest among parents and non-athletes. Southern Medical Journal. 84:552-556, 1991.

103. Scarpino, V., A. Arrigo, G. Benzi, S. Garattini, C. La Vecchia, L. R. Bernadi, G. Silvestrni, and G. Tuccimei. Evaluation of prevalence of doping among Italian athletes. Lancet. 336:1048-1050, 1990.

104. Schneider, D. and J. Morris. College athletes and drug testing: Attitudes and behaviours by gender and sport. Journal of Athletic Training. 28:146-150, 1993.

105. Schwerin, M. J. and K. J. Corcoran. Beliefs about steroids: User vs non-user comparisons. Drug and Alcohol Dependence. 40:221-225, 1996.

106. Schwerin, M. J. and K. J. Corcoran. A multimethod examination of the male anabolic steroid user. Journal of Applied Social Psychology. 26:211-217, 1996.

107. Schwerin, M. J. and K. J. Corcoran. What do people think of male steroid users? An experimental investigation. Journal of Applied Social Psychology. 22:833-840, 1992.

108. Schwerin, M. J., K. J. Corcoran, B. J. LaFleur, L. Fisher, D. Patterson, and T. Olrich. Psychological predictors of anabolic steroid use: An exploratory study. Journal of Child and Adolescent Substance Abuse. 6:57-68, 1997.

109. Sharpe, K. Using the economic method to investigate drugs in sport. In: ACSPRI Social Science Methodology Conference The University of Sydney, Sydney, Australia, 2006.

110. Shields, E. W. Sociodemographic analysis of drug use among adolescent athletes: Observationsperceptions of athletic directors-coaches. Adolescence. 30:849-861, 1995.

111. Shirazi, A. The perceptions of head athletic trainers in NCAA division 1, 2, and 3, members institutions towards the status of alcohol, tobacco and other drug (ATOD) prevention and education policies. Oregon State University, 2003.

112. Shirazi, A. and R. Tricker. Current drug education policies in NCAA institutions: perceptions of head athletic trainers. Journal of Drug Education. 35:29-46, 2005.

113. Singer, P. Practical Ethics. Oxford: Oxford University Press. , 1981

114. Somerville, S. J. and M. Lewis. Accidental breaches of the doping regulations in sport: Is there a need to improve the education of sportspeople. British Journal of Sports Medicine. 39:512-516, 2005.

115. Spence, J. C. and L. Gauvin. Drug and alcohol use by Canadian university athletes: A national survey. Journal of Drug Education. 26:275-287, 1996.

116. Starkey, C., T. E. Abdenour, and D. Finnane. Athletic trainers attitudes toward drug screening of intercollegiate athletes. Journal of Athletic Training. 29:120-125, 1994.

117. Stilger, V. G. and C. E. Yesalis. Anabolic-androgenic steroid use among high school football players. Journal of Community Health. 24:131-145, 1999.

118. Strelan, P. and R. Boeckmann. Why Drug Testing in Elite Sport Does Not Work: Perceptual Deterrence Theory and the Role of Personal Moral Beliefs. Journal of Applied Social Psychology. 36:2909-2934, 2006.

119. Strelan, P. and R. J. Boeckmann. A new model for understanding performance enhancing drug use by elite athletes. Journal of Applied Sport Psychology. 15:176-183, 2003.

120. Striegel, H., P. Simon, S. Frisch, K. Roecker, K. Dietz, H. H. Dickhuth, and R. Ulrich. Anabolic ergogenic substance users in fitness sports: A distinct group supported by the health care system. Drug and Alcohol Dependence. 81:11-19, 2006.

121. Striegel, H., G. Vollkommer, and H. H. Dickhuth. Combating drug use in competitive sport. An analysis from the athletes' perspective. Journal of Sports Medicine and Physical Fitness. 42:354359, 2002. 
122. Tangen, J. O., N. A. Bergsgard, B. Barland, and G. Breivik. To dope or not to dope: A study on the decision to use drugs in Norwegian sports. Corpus, Psyche et Societas. 4:41-65, 1997.

123. Terney, R. and L. McLain. The use of anabolic steroids in high school students. American Journal of Disease in Children. 144:99-103, 1990.

124. Tonigan, J., R. Toscova, and G. Connors. Spirituality and the 12-Step Programme. In: Integrating Spirituality into Treatment. W. Miller (Ed.) Washington: American Psychological Association., 2003.

125. Trenhaile, J., H. S. Choi, T. B. Proctor, and P. Work. The effect of anabolic steroid education on knowledge and attitudes of at risk preadolescents. Journal of Alcohol and Drug Education. 43:20$31,1998$.

126. Tricker, R. and D. Connolly. Drug education and the college athlete: evaluation of a decision making model. Journal of Drug Education. 26:159-181, 1996.

127. Tricker, R. and D. Connolly. Drugs and the college athlete: An analysis of the attitudes of student athletes at risk. Journal of Drug Education. 27:105-119, 1997.

128. UKSport. Drug Free Sport Survey. London: UK Sport, 2005.

129. UnitedStatesAnti-DopingAgency. Educational Program Development Athlete Survey, 2001/2002.

130. Van Raalte, J. L., K. A. Cusimano, and B. W. Brewer. Perceptions of anabolic steroid users. Journal of Applied Social Psychology. 23:1214-1225, 1993.

131. Vogels, T., E. Brugman, B. Coumans, M. J. Danz, R. A. Hirasing, and E. Van Kernbeek. Correlates of the use of performance enhancing drugs among young patrons of gymnasiums in the Netherlands. Drugs: Education Prevention and Policy. 3:39-48, 1996.

132. Waddington, I. Sport, health and drugs: a critical sociological perspective. E \& FN Spon, Taylor Francis Group, London, 2000.

133. Waddington, I., Malcolm, D., Roderick, M., Naik, R. Drug use in English professional football. British Journal of Sports Medicine. 39:e18, 2005.

134. Wagman, D., L. Curry, and D. Cook. An investigation into anabolic androgenic steroid use by elite US powerlifters. Journal of Strength and Conditioning Research. 9:149-154, 1995.

135. Warner, D. C., G. Schnepf, M. S. Barrett, D. Dian, and N. L. Swigonski. Prevelance, attitudes and behaviours related to use of nonsteroidal anti-inflammatory drugs (NSAIDs) in student athletes. Journal of Adolescent Health. 30:150-153, 2002.

136. Wichstrom, L. Predictors of future anabolic androgenic steroid use. Medicine and Science in Sports and Exercise. 38:1578-1583, 2006.

137. Wright, S., S. Grogan, and G. Hunter. Body-builders' attitudes towards steroid use. Drugs: Education Prevention and Policy. 8:91-97, 2001.

138. Wroble, R. R., M. Gray, and J. A. Rodrigo. Anabolic steroids and pre adolescent athletes: Prevalence, knowledge and attitudes. The Sport Journal. 5, 2002.

139. Yesalis, C. E., W. E. Buckley, W. A. Anderson, M. Q. Wang, J. A. Norwig, G. Ott, J. C. Puffer, and R. H. Strauss. Athletes projections of anabolic steroid use. Clinical Sports Medicine. 2:155$171,1990$. 
$\begin{array}{ll}\text { Author } & \text { Secondary Author(s) } \\ \text { Alaranta, A. } & \text { Alaranta, H., Holmila, J., Palmu, P., Pietila, K., Helenius, I. }\end{array}$

Title

Self-reported attitudes of elite athletes towards doping: Differences between type of sport.

Publication

International Journal of Sports Medicine

Publication Year

Volume, Issue, Pages

February

Sample: Elite athletes

Design: Cross-sectional survey (questionnaire)

Location: Finland

Key words: Attitudes, Doping, Type of sport

Theory(s) applied: N/A

\section{Summary}

Attitudes of 446 elite athletes receiving financial support from the National Finnish Olympic Committee were examined by questionnaire. Responses were compared by sporting type, with subjects categorised as speed and power athletes, endurance athletes, skill-based athletes or team-sport athletes.

None of the athletes admitted doping. Overall, $90 \%$ of athletes believed that performance could be improved with the use of banned substances. Over $90 \%$ believed it was possible to reach the highest level of achievement without doping. Athletes from skill-based events were most likely to indicate that banned substances were not effective in enhancing performance. Forty-two percent of athletes in speed and power sports reported that they knew of another athlete using banned substances, whilst just $17 \%$ from skill-based sports shared this view. Across all sports, men were more likely to know of another athlete using doping agents than women. Seven percent of athletes stated they would start using currently banned substances if they were allowed, and 3\% believed that doping agents could be used completely or nearly without adverse effects. Athletes who considered use of banned substances not to be harmful were twice as likely to know another athlete using doping practices.

A high response rate allows findings to be generalised to the wider population of elite Finnish athletes. Limitations associated with the use of questionnaires, especially with regard to illegal or taboo practices, means that results should be interpreted with caution.

Author

Secondary Author(s)

Albrecht, R.R. $\quad$ Anderson, W.A., McGrew, C.A., McKeag, D.B., Hough, D.O

Title

NCAA institutionally based drug testing: Do our athletes know the rules of this game?

Publication

Medicine and Science in Sports and Exercise

Publication Year

Volume, Issue, Pages

1992

$24 ; 2 ; 242-246$

Sample: College athletes

Design: Cross-sectional survey (questionnaire)

Location: United States

Key words: Drug testing, Informed consent

Theory(s) applied: N/A

\section{Summary}

The study examined the extent to which college athletes are informed about the drug testing procedures employed by their institution. Items relevant to the present study were extracted from a larger survey of drug related issues amongst college athletes. The sample comprised 2282 athletes from a range of sports, including football, tennis and swimming.

Approximately $7 \%$ of respondents attending 'non-testing' institutions incorrectly believed that they may be subject to some form of drug testing. Thirty six percent of athletes enrolled at institutions where drug testing programmes were in effect indicated that they were ignorant of any testing taking place (21\%) or incorrectly stated that testing did not occur (15\%). Of all subjects attending colleges with drug testing procedures in place, approximately $70 \%$ were unable to correctly identify the testing protocol (voluntary/mandatory, random/announced, all sports/some sports). Individuals who were aware that they were susceptible to testing were more inclined to view such procedures as an effective deterrent to drug use. The implications of this lack of knowledge for athletes, officials and the college or university as a whole are discussed.

Athletes' attitudes towards doping or recreational drug use are not explored. All subjects were volunteers, introducing the possibility of selection bias in the sample. 

Author
Secondary Author(s)
Ama, P.F.M. Betnga, B., Ama Moor, V.J., Kamga, J.P.

Title

Football and doping: study of African amateur footballers.

Publication

British Journal of Sports Medicine

Publication Year

2003

Design: Cross-sectional survey (questionnaire)

Theory(s) applied: N/A
Volume, Issue, Pages $37 ; 307-310$

Location: Cameroon

Key words: Football, Doping

Summary

The study investigated drug use amongst Cameroonian footballers. The sample comprised 723 amateur players, 314 professional footballers and 79 female footballers. Subjects completed a thirty-item questionnaire, which focused primarily on use and awareness of social/recreational drugs, doping substances and nutritional supplements.

Awareness of certain banned substances was quite low in this sample, with $60 \%$ stating they did not know about cocaine, $68 \%$ were not aware of anabolic steroids and $74 \%$ had not heard of amphetamines. Seven percent of all respondents indicated that they had used cocaine before a match, with greatest use amongst local players (8\%), followed by professional footballers (5\%) and female players (3\%). A small percentage (6\%) of amateur and professional players reported using liboga (a plant root with stimulating effects) before matches.

Although knowledge was assessed through awareness of doping methods, subjects' attitudes or beliefs about doping practices was not examined. Results should be interpreted with caution due to the use of self-report questionnaires.

\section{Author}

Secondary Author(s)

Anderson, W.A.

Albrecht, R.R., McKeag, D.B., Hough, D.O., McGrew, C.A

Title

A national survey of alcohol and drug use by college athletes.

Publication

Publication Year

The Physician and Sportsmedicine

1991

Volume, Issue, Pages

Sample: College athletes

Design: Cross-sectional survey (questionnaire)

$19 ; 2 ; 91-104$

Key words: Opinions, Alcohol and drug use

Theory(s) applied: N/A

Summary

Funded by the National Collegiate Athletic Association (NCAA), this study surveyed 2282 male and female college athletes by questionnaire. Rates of performance enhancing and recreational drug use are compared with those of non athletes reported in previous research. Attitudes toward current drug testing procedures are also assessed. Data from the present survey are compared to those collected in a similar study in 1985 .

Five percent of athletes reported using anabolic steroids, showing little change from the 1985 survey. There were significant reductions in the number of athletes using amphetamines, cocaine and marijuana over the same period. Sixty-five percent of respondents either agreed or strongly agreed that all athletes should be tested for drugs by their institution and/or the NCAA. Only $37 \%$ believed that imposing penalties on the entire team when an individual tested positive for illegal drugs was fair and appropriate. Fiftysix percent of athletes indicated that drug testing by their school had deterred drug use, whilst $58 \%$ indicated that testing by the NCAA deterred use.

The possibility of underreporting and the use of a stratified sampling procedure mean that results should be interpreted and generalised with caution. 


$\begin{array}{ll}\text { Author } & \text { Secondary Author(s) } \\ \text { Anshel, M.H. } & \text { Russell, K.G } \\ \text { Title } & \end{array}$

Examining athletes' attitudes toward using anabolic steroids and their knowledge of the possible effects.
Publication
Publication Year
Volume, Issue, Pages
Journal of Drug Education
1997
$27 ; 2 ; 121-145$

Sample: Elite athletes

Design: Cross-sectional survey (questionnaire)

Location: Australia

Key words: Attitudes, Knowledge, Anabolic steroids

Theory(s) applied: Health Belief Model, Theory of Reasoned Action

Summary

Numerous education based programmes have been implemented to reduce anabolic steroid use in sport. Underlying the use of such programmes is the belief that increased knowledge about the effects of prolonged steroid use is associated with a disapproving attitude toward such substances and consequently reduced usage. The present study examined the relationship between an athletes' knowledge about the long term effects of steroid use and their attitudes toward this type of drug. The sample comprised 291 male and female elite track and field athletes. Questionnaire development and interpretation of findings is informed by the Health Belief Model and Theory of Reasoned Action.

Multiple regression analysis indicated relatively low R2 values and correlations between various components of subjects' knowledge and their attitude toward steroid ingestion. Greater knowledge about steroids and their effects on the athletes' physical and mental health was not significantly related to their attitudes about using steroids in sport. The author comments that existing educational programmes may have limited value in terms of creating appropriate attitudes to reduce steroid use.

The study employs lengthy methods in data analysis such that some degree of statistical knowledge is necessary to enable thorough understanding of findings.

Author

Secondary Author(s)

Anshel, M.H.

Title

A survey of elite athletes on the perceived causes of using banned drugs in sport.

Publication

Publication Year

Volume, Issue, Pages

Journal of Sport Behaviour

1991

$14 ; 4 ; 283-307$

Sample: Elite athletes

Design: Cross-sectional survey (questionnaire/interview) Location: Australia

Key words: Perceived causes, Recreational drugs

Theory(s) applied: Problem Behaviour Theory

Summary

One hundred and twenty six elite athletes (94 male, 32 female) were interviewed to examine their feelings about performance enhancing and recreational drug use by team-mates based on their personal interactions with them.

Reasons for using performance enhancing drugs fell into three categories: physical, psychological/emotional and social. Among physical explanations were to reduce pain, speed recovery from injury, increase or decrease energy and arousal (usually dependant on the sport). Psychological and emotional causes included fear of failure and lack of self-confidence. Lastly, social causes included modelling of significant others or rewarded behaviour and a lack of social support, especially amongst female athletes. Findings are explored using Jessors (1982) Problem Behaviour Theory, wherein athletes view drug use as desirable, or even necessary, due to situational demands, implications, expectations, roles or personal needs.

Limitations to the present study include use of a non random sample and an extensive period of data collection during which the topic received much media attention, which may have influenced subjects' responses. 
$\begin{array}{ll}\text { Author } & \text { Secondary Author(s) } \\ \text { Ardito, F. } & \text { Goldstein, P., Bahrke, M., Satler, T. }\end{array}$

Title

Anabolic steroid use: prevention and education.

Publication

International Journal of Drug Policy

Publication Year

1994
Volume, Issue, Pages $5 ; 1 ; 27-33$

Sample: Recreational athletes

Design: Cross-sectional survey (questionnaire/interview)

Location: United States

Key words: Attitudes, Perceptions, Anabolic steroids

Theory(s) applied: N/A

Summary

The paper reports on a pilot study which examined the perceptions of 10 steroid users and 10 non-users regarding steroid prevention and education programmes. All subjects had a history of either organised sports participation or bodybuilding. The study served to gather data which would be used to inform design and hypothesis development of a larger research programme.

Nineteen out of twenty subjects believed that they were more concerned about their weight and/or body shape than other males. Eighty percent of non-users compared to just $20 \%$ of users stated that steroid use could be detrimental to health. Only $30 \%$ of steroid users believed that drug testing was an effective deterrent to steroid use in sport. Both users and non-users agreed that sufficient medical research exists to support the belief that steroids work, but $90 \%$ of users reported that there was insufficient evidence to support the belief that steroids could be harmful. Only 3 out of 20 subjects had attended a steroid prevention or education programme.

Due to the small sample size, statistical methods could not be employed in the usual manner. The value of this study lies in its capacity to inform future research rather than as a rigorous piece of work in its own right.

\author{
Author Secondary Author(s) \\ Bents, R.T. Tokish, J.M., Goldberg, L \\ Title \\ Ephedrine, pseudoephedrine, and amphetamine prevalence in college hockey players. \\ Publication \\ Physician \& Sportsmedicine \\ Publication Year \\ 2004 \\ Design: Cross-sectional survey (questionnaire) \\ Sample: College athletes \\ Volume, Issue, Pages \\ $32 ; 9 ; 30-35$ \\ Location: United States
}

Theory(s) applied: N/A

Key words: Attitudes, Knowledge, Stimulants

\author{
Theory(s) applied: $N$ A
}

\title{
Summary
}

This paper examines the use of metabolic stimulants among 122 collegiate hockey players, using a survey design. It is worth noting that six teams were given the survey, but one team's head coach elected not to participate.

Results demonstrated that more than half (58\%) of the athletes surveyed reported past or present use of the metabolic stimulants examined. Almost half (46\%) reported pseudoephedrine use to enhance performance ( $24 \%$ indicated current use) and $38 \%$ reported ephedrine use (11\% indicated current use). Over 33\% stated they would use a banned substance if it would help them get to the National Hockey League, despite nearly all (92\%) stimulant users being aware of the current NCAA ban of ephedrine. Almost $19 \%$ of non-stimulant users stated they intended to use NCAA-banned substances at some point in their college careers. Nearly all players demonstrated awareness of and belief in the potential side effects of stimulant use.

This study has a number of limitations. Firstly, only one conference was examined and therefore the results may not represent the national perspective. Secondly, the sample size was small and may be subject to underestimation given the decision of one coach not to allow his athletes to partake in the survey.

This paper examines the use of metabolic stimulants among 122 collegiate hockey players, using a survey design. It is worth noting that six teams were given the survey, but one team's head coach elected not to participate. Results demonstrated that more than half $(58 \%)$ of the athletes surveyed reported past or present use of the metabolic stimulants examined. Almost half (46\%) reported 


\author{
Author Secondary Author(s) \\ Chester, N. Reilly, T., Mottram, D.R. \\ Title
}

Over-the-counter drug use amongst athletes and non-athletes.

Publication

Journal of Sports Medicine and Physical Fitness

Publication Year

2003
Volume, Issue, Pages

43; $1 ; 111-118$

Location: United Kingdom

Sample: Elite athletes/non-athletes

Design: Cross-sectional survey (questionnaire)

Key words: Over-the-counter drugs, Doping risk

Theory(s) applied: N/A

Summary

Some over-the-counter (OTC) medicines, especially those used for the treatment of upper respiratory tract (URT) infections, contain substances that are banned by sports governing bodies. This paper reports on a survey of athletes (elite and non-elite) and nonathletes with regard to use of and attitudes toward these substances.

Three percent of athletes stated they had used OTC drugs to enhance performance, but less than half of those believed they had been effective. A higher proportion of elite, as opposed to non-elite, athletes did not take OTC medicines. Of those that did use OTC treatments, elite athletes were more likely to use only those which did not contain banned substances. Only twenty-three percent of athletes and $14 \%$ of non-athletes believed that OTC drugs should be banned. Within the athlete subgroup, elite athletes were more likely than non-elite athletes to have greater knowledge of OTC drugs and support their prohibition. The author suggests that doping control programmes are ineffective, because they are only reaching elite athletes and not those who have the potential to become elite.

Problems associated with data collection by questionnaire should be acknowledged in interpretation of these findings. Due to their impact on training, athletes may have been more likely to report URT infections than non-athletes, introducing a possible response bias.

\author{
Author Secondary Author(s) \\ Chng, C.L. Moore, A. \\ Title \\ A study of steroid use among athletes: Knowledge, attitude and use. \\ Publication \\ Publication Year \\ Volume, Issue, Pages \\ Health Education \\ 1990 \\ $21 ; 6 ; 12-17$ \\ Sample: University athletes \\ Design: Cross-sectional survey (questionnaire) \\ Location: United States
}

Key words: Attitudes, Knowledge, Anabolic steroids $\quad$ Theory(s) applied: N/A

Summary

The study investigated knowledge, attitudes and prevalence of anabolic steroid use in 222 university students and gym members, all of whom were volunteers. The study population was selected because it contained a large portion of steroid users, according to anecdotal reports by athletes, coaches and sports administrators in the community. A 32-item questionnaire was used to gather data.

Overall prevalence of anabolic steroid use was $23 \%$, with greater usage in males than females. Males were generally more knowledgeable and more positive in their attitude toward steroids than females. Athletes were found to have greater use and knowledge of steroids and a generally more positive attitude toward their usage than non-athletes. A significant moderate correlation was identified between attitude and knowledge, such that the more an individual knew about steroids the more favourable was their attitude towards them. The most frequently reported motives for steroid use were to get stronger or look more muscular, to improve the chances of becoming a professional athlete or to earn more money. Reasons for not using steroids included fears that they were harmful and produced unpleasant side-effects and that fact that they are illegal.

Knowledge and attitude scores are composites of all relevant questionnaire items, thus individual points and discrepancies cannot be analysed in-depth or highlighted for future research. Findings may be limited by a response bias associated with the use of volunteers as subjects. 


\author{
Author Secondary Author(s) \\ Coombs, R.H. Ryan, F.J. \\ Title
}

Drug testing effectiveness in identifying and preventing drug use.

Publication

American Journal of Drug and Alcohol Abuse

Publication Year

1990
Volume, Issue, Pages $16 ; 3 / 4 ; 173-184$

Sample: College athletes

Key words: Drug testing, Prevention

Design: Cross-sectional survey (questionnaire/interview)

Location: United States

Theory(s) applied: N/A

Summary

The impact of a mandatory drug testing programme on the morale and well-being of college athletes was examined. Information was gathered from 500 subjects ( $71 \%$ male) on drug use, attitudes towards drug education and testing programmes, and the impact of testing upon drug use behaviour, morale and well-being, using a 75-item questionnaire. A sub sample of 57 respondents also took part in an in-depth interview exploring similar issues.

The majority of respondents (71\%) reported that taking part in the drug test was 'no big deal', whilst 37\% stated it was 'interesting' and '36\% that it was 'educational'. Comments from interviews in support of this included "it was 15 minutes out of my year" and "Its an interesting conversation piece". Some adverse effects of testing were reported. Forty-seven percent reported that testing was 'embarrassing', 36\% that it was 'humiliating' and 26\% that it was 'upsetting'. Forty-seven percent of respondents indicated that testing caused non-using athletes to worry about being falsely identified as a user and $38 \%$ stated that it adversely affected athletes' morale. Some beneficial outcomes of testing were also identified, such that $27 \%$ of athletes indicated testing had improved their athletic performance. Suggestions as to how the testing experience could be improved related to making the process more dignified, improving education sessions, making the setting for testing more comfortable and making standards more rigorous.

Results from this study are generated from a sample also used by Issari and Holman-Coombs (1998) and Coombs and Ryan (1990).

$\begin{array}{ll}\text { Author } & \text { Secondary Author(s) } \\ \text { Coombs, R.H. } & \text { Coombs, C.J. }\end{array}$

Title

The impact of drug testing on the morale and well-being of mandatory participants.

Publication

The International Journal of Addictions

Publication Year

1991

Volume, Issue, Pages

26; 9; 981-992

Sample: College athletes

Design: Cross-sectional survey (questionnaire/interview) Location: United States

Key words: Morale, Drug testing

Theory(s) applied: N/A

Summary

The impact of a mandatory drug testing programme on the morale and well-being of college athletes was examined. Information was gathered from 500 subjects ( $71 \%$ male) on drug use, attitudes towards drug education and testing programmes, and the impact of testing upon drug use behaviour, morale and well-being, using a 75-item questionnaire. A sub sample of 57 respondents also took part in an in-depth interview exploring similar issues.

The majority of respondents (71\%) reported that taking part in the drug test was 'no big deal', whilst $37 \%$ stated it was 'interesting' and '36\% that it was 'educational'. Comments from interviews in support of this included "it was 15 minutes out of my year" and "Its an interesting conversation piece". Some adverse effects of testing were reported. Forty-seven percent reported that testing was 'embarrassing', 36\% that it was 'humiliating' and 26\% that it was 'upsetting'. Forty-seven percent of respondents indicated that testing caused non-using athletes to worry about being falsely identified as a user and $38 \%$ stated that it adversely affected athletes' morale. Some beneficial outcomes of testing were also identified, such that $27 \%$ of athletes indicated testing had improved their athletic performance. Suggestions as to how the testing experience could be improved related to making the process more dignified, improving education sessions, making the setting for testing more comfortable and making standards more rigorous.

Results from this study are generated from a sample also used by Issari and Holman-Coombs (1998) and Coombs and Ryan (1990). 

Author
Secondary Author(s)
Corbin, C.B.
Feyrer-Melk, S.A., Phelps, C., Lewis, L.

Title

Anabolic steroids: A study of high school athletes.

Publication

Pediatric Exercise Science

Publication Year

1994

Design: Cross-sectional survey (questionnaire)
Volume, Issue, Pages 6; 149-158

Location: United States

Sample: High school athletes

Theory(s) applied: N/A

Key words: Prevalence, Attitudes, Anabolic steroids

Summary

Researchers assessed 1680 high school athletes for use of anabolic steroids and explored factors that characterised steroid users such as attitudes, availability and peer influence. Subjects were predominantly male, in grades 8-11.

Steroid use rates were $2.4 \%$ for males and $1.1 \%$ for females. Males reported greater availability of steroids and were more likely to know someone who sold them or used them. Availability and knowledge of other users increased with grade level. Eight percent of males, compared to just $2 \%$ of females stated they would use steroids if they were legal. Approximately $10 \%$ of all subjects indicated they would use steroids if it would guarantee them an Olympic medal. For both males and females, personal factors such as having considered steroid use, a willingness to use them if they were legal and a willingness to use them if they could insure success in sports were the most useful in classifying athletes as steroid users versus non-users. Just under $3 \%$ of subjects knew a coach or school official that helped athletes get steroids.

Due to the controversial subject matter caution must be exercised when interpreting findings as collected by questionnaire. A number of additional variables, not assessed in the survey, may impact upon the use of anabolic steroids.

$\begin{array}{ll}\text { Author } & \text { Secondary Author(s) } \\ \text { Curry, L.A. } & \text { Wagman, D.F. } \\ \text { Title } & \end{array}$

Qualitative description of the prevalence and use of anabolic androgenic steroids by United States powerlifters.
Publication
Publication Year
Volume, Issue, Pages
Perceptual and Motor Skills
1999
$88 ; 1 ; 224-233$

Sample: Elite athletes

Design: Cross-sectional survey (open-ended questionnaire) Location: United States

Key words: Attitudes, Commentary, Drug testing

Theory(s) applied: N/A

\section{Summary}

The study used a questionnaire to obtain yes/no responses to key issues relating to use of and experience with anabolic steroids and drug testing, with the option to expand on each answer through open commentary. Responses were collected from 15 elite US Powerlifters.

Ten respondents admitted to having used anabolic steroids. Five reported that they had beaten the International Olympic Committees doping control procedures. All subjects indicted that they suspected steroid use amongst other Powerlifters at National and International competitions, accompanied by comments that subjects 'knew for a fact' this was happening and that it was 'no secret'. Ten respondents stated that steroids could be used in sufficient dosage to improve performance without hazard to health. Eleven subjects reported that they would prefer a situation where no performance enhancing drugs were allowed and detection was $100 \%$ effective.

The study was solely qualitative in nature, thus data cannot be tested using statistical techniques and findings should not be generalised to other populations. 


\author{
Author Secondary Author(s) \\ Diacin, M.J. Parks, J.B., Allison, P.C. \\ Title
}

Voices of male athletes on drug use, drug testing and the existing order in intercollegiate athletics.

Publication

Journal of Sport Behaviour

Publication Year

2003

Volume, Issue, Pages

$26 ; 1 ; 1-16$

Sample: College athletes

Key words: Voices, Constructivism

Design: Qualitative survey (interview)

Summary

The study used semi-structured interviews to examine the perspectives of 8 male intercollegiate athletes on drug use and testing. Subjects were predominantly Caucasian, aged 20-22 and represented a range of academic subjects including business, marketing and education. Theories of reinforcement, pragmatic role acceptance and organisational deviance framed data analysis.

Students generally rejected the use of performance enhancing substances in sport and supported the testing of college athletes for doping agents and recreational drugs. Three themes emerged in the responses of athletes: factors influencing athletes' perceptions of the use of performance enhancing substances, privacy issues relating to drug testing and negotiating the meaning of fairness. Coaches and peers/team-mates were the primary shapers of beliefs about drug use. The author refers to theories of reinforcement developed by Bandura (1977) to explain these perceptions. Athletes indicated that representing their university in sport was a privilege and that drug testing was not an invasion of privacy but an acceptable part of that privilege, suggestive of pragmatic role acceptance among college athletes. Testing for certain substances was justified most frequently on the basis that it ensured fair competition. Some athletes expressed concern at the repeated testing of athletes who tested negative for performance enhancing substances. The author asserts that findings in this study are context-bound, thus it is not appropriate to make generalisations to the wider college population.

\author{
Author \\ Secondary Author(s) \\ Fjeldheim, T.B. \\ Title \\ Sports instructors and sports leaders: Attitudes toward doping in sports
}

Publication

Collegium Anthropologicum

Publication Year

1992

Design: Cross-sectional survey (questionnaire)
Volume, Issue, Pages

$16 ; 2 ; 343-348$

Location: Norway

Sample: Sports instructors/leaders

Theory(s) applied: N/A

Key words: Attitudes, Knowledge, Doping

\title{
Summary
}

One hundred sports instructors and sports leaders completed a questionnaire regarding their knowledge of and attitudes toward doping in sport. All participants were drawn from a small community in south-eastern Norway.

Ninety-eight percent of respondents stated that it is cheating to use doping practices in sport and $94 \%$ stated it should be banned due to possible negative side effects. All sports leaders and instructors believed they had a role to play in preventing doping. Ten percent of subjects believed that doping controls in Norway were too strict, whilst 37\% indicated that they thought it was unfair that Norwegian athletes were subject to stricter controls than those from other nations. Knowledge of doping issues was generally lacking. Fo example, $25 \%$ were unable to mention a single method of doping in sport and $46 \%$ were not aware of laws relating to being an accessory to use of anabolic steroids.

Interpretation and discussion of findings is brief and lacks in-depth analysis. The authors adopt an informal writing style that, whilst accessible, perhaps undermines the credibility of the article. 


\begin{tabular}{|c|c|c|c|}
\hline $\begin{array}{l}\text { Author } \\
\text { Fung, L. }\end{array}$ & $\begin{array}{l}\text { Secondary Author(s) } \\
\text { Yuan, Y. }\end{array}$ & & \\
\hline \multicolumn{4}{|c|}{$\begin{array}{l}\text { Title } \\
\text { Performance enhancement drugs: Knowledge, attitude and intended behavior among community coaches in Hong Kong }\end{array}$} \\
\hline $\begin{array}{l}\text { Publication } \\
\text { The Sport Journal }\end{array}$ & & $\begin{array}{l}\text { Publication Year } \\
2006\end{array}$ & $\begin{array}{l}\text { Volume, Issue, Pages } \\
9 ; 3\end{array}$ \\
\hline Sample: Coaches (community) & Design: Cross-se & ey (questionnaire) & Location: Hong Kong \\
\hline
\end{tabular}

Key words: Attitudes, Knowledge, Behavioural intent Theory(s) applied: Theory of Planned Behaviour

\section{Summary}

This paper examines doping knowledge, attitudes and behavioural intentions of community coaches attending a coach education class in Hong Kong. The sample comprised 114 coaches (93 males), with a mean age of 29 years (SD \pm 8.1 ) and the Theory of Planned Behaviour informed the study design.

Overall, community coaches reported negative attitudes towards doping in sport with the majority of coaches (70\%) disagreed that "refusal to take performance drugs equals to refraining from being an elite athlete". Further, their behavioural intentions were not supportive of doping in sport. For example, $63 \%$ of coaches disagreed that they would find ways to assist friends or relatives (significant others) to get hold of banned substances. Paradoxically, $20 \%$ of coaches agreed that scientific research should develop drugs that can pass tests of doping control. Subjective norms were also analysed in this investigation, however, one could argue that the questions do not represent this dimension of the attitude-behaviour theory. Indeed, the relationship between subjective norm and behavioural intent was not significant, although behavioural intention was related to the coaches' attitude, perceived knowledge and actual knowledge. However, the magnitude of the relationships was small $(r=\sim 0.3)$.

This paper is strengthened by its application of social-cognitive theory, but the tenets of the Theory of Planned behaviour were not fully explored and the questionnaire employed was not psychometrically validated.

$\begin{array}{ll}\text { Author } & \text { Secondary Author(s) } \\ \text { Gray, G.R. } & \text { Schoof, R.J. }\end{array}$

Drug testing collegiate student athletes: Opinions of athletes and nonathletes.

Publication

Journal of Legal Aspects of Sport

Sample: University athletes

Key words: Opinions, Drug testing

Design: Cross-sectional survey (questionnaire)

Publication Year

1993 sue, Pages

$3 ; 1 ; 51-58$

Location: United States

Summary

The study compared the opinions of 70 male athletes with 70 male non-athletes, on a range of issues relating to drug testing in college. A 34-item questionnaire was designed to explore 4 distinct themes relating to drug testing; the concept of drug testing generally, legal issues relating to drug testing, procedures for conducting tests, and possible sanctions following a first time positive test.

Both groups indicated that drug testing of athletes was a good idea, because it prevented unfair advantage. However, only athletes supported the contention that non-athletes should also be subject to drug testing. Athletes and non-athletes showed considerable disagreement on the subject of what sanctions should be imposed upon an individual testing positive for the first time. Non-athletes were generally supportive of more stringent treatment for the offending athlete, more likely to support measures to reduce the athlete's financial aid and penalise the entire team. Athletes were more inclined to report that administrators were exaggerating the extent of the drug problem in college and suggested that athletes should be entitled to refuse a drug test without penalty.

All subjects were drawn from a single university; therefore the sample is unlikely to be representative of the student body nationwide. 


\author{
Author Secondary Author(s) \\ Greenway, P. Greenway, M. \\ Title
}

General Practitioner knowledge of prohibited substances in sport.

Publication

British Journal of Sports Medicine
Publication Year

1997
Volume, Issue, Pages $31 ; 129-131$
Sample: General Practitioners

Design: Cross-sectional survey (postal questionnaire)

Location: United Kingdom
Theory(s) applied: N/A

Key words: Knowledge, General Practitioners

Summary

This short paper presents findings from a postal survey conducted to examine General Practitioners' knowledge of banned substances in sport. All GP's were based in West Sussex, UK.

Only 35\% of GP's were aware that information regarding banned substances in sport could be found in the British National Formulary. Between $60-80 \%$ of GP's correctly identified the following substances as permitted in sport; inhaled salbutamol/salmeterol, inhaled corticsteroids and paracetamol. Approximately $30-40 \%$ were unaware that oral corticosteroids and dextropropoxyphene are not permitted. Twelve percent of respondents incorrectly stated that GP's are permitted to prescribe anabolic steroids for non-medical reasons.

Response rate to the postal questionnaire was low (39\%). The survey was short and simplistic in its content, thus detailed examination of this subject area is not possible.

$\begin{array}{ll}\text { Author } & \text { Secondary Author(s) } \\ \text { Grove, J.R. } & \text { Paccagnella, M. }\end{array}$

Title

Tall poppies in sport: Attitudes and ascribed personality traits.

Publication

Australian Psychologist

Sample: University students

Publication Year

1995
Volume, Issue, Pages

$30 ; 2 ; 88-91$

Location: United States

Key words: Attitudes, Personality, Tall Poppies

Theory(s) applied: Tall Poppy Syndrome, 'Just World Effect'

Summary

The study investigates the 'Tall Poppy Syndrome' which describes a tendency to closely scrutinise high-profile individuals, search for reasons to 'cut them down to size' and experience satisfaction when such individuals suffer a reversal of fortune. One-hundred and thirty nine university students rated two contrasting groups of high-profile athletes in terms of their attitudes towards them and ascribed personality traits. Group A (Martina Navratilova, Magic Johnson, Ben Johnson) had been subject to publicity for being gay, HIV positive or a steroid user, whilst group B had not (Monica Seles, Micheal Jordan, Carl Lewis).

In support of the authors' hypotheses subjects reported that they would rather be similar to athletes in group B than A, and that they would like these athletes more and be happier to spend time socially with them. In addition, athletes from group A were considered to be less trustworthy, rule-orientated or honest and have less integrity and self control. It is suggested that evaluation of Tall Poppies is shaped by high expectations of how athletes should behave. Athletes who are perceived to violate the generally conservative values upheld in sport, such as fair play, discipline and achievement through hard work, are subject to harsh judgement.

Subjects' perceptions of a steroid user were not compared with those of 'clean' athletes or those facing other forms of stigmatisation. 


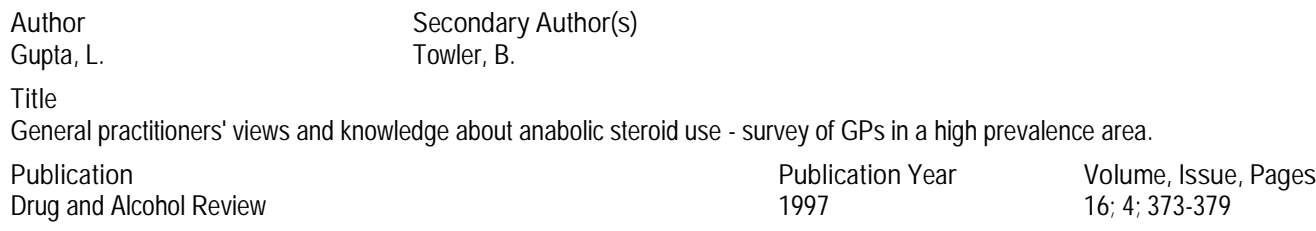

Publication Year

1997

Volume, Issue, Pages $16 ; 4 ; 373-379$

Sample: General Practitioners

Design: Cross-sectional survey (postal questionnaire)

Key words: Attitudes, Knowledge, Anabolic steroids

Theory(s) applied: N/A

Summary

Examined General Practitioners attitudes, clinical behaviour, information needs and contact with anabolic-androgenic steroid users, in an inner city district where high prevalence of steroid use had been reported. Data was gathered by questionnaire from 143 , predominantly male, GP's.

Thirty seven percent of respondents stated that they had seen between 1-5 patients who said they had ever used anabolic steroids in the previous 12 months, with a further $6 \%$ reporting they had seen more than 20 patients with previous steroid use over the same period. Two percent stated they had prescribed steroids for bodybuilding purposes in the previous year, $6 \%$ indicated a willingness to do so in a hypothetical situation and $21 \%$ reported that they knew of at least one GP in the New South Wales region who prescribed steroids for non-medical reasons. Forty percent of respondents indicated they would be prepared to provide advice on side effects and safe injecting techniques to steroid users. Just over half of GP's (54\%) felt that they had sufficient knowledge to advise users on possible side effects, whilst $77 \%$ stated they would like more information about steroid use.

Researchers intentionally selected a region with high prevalence of steroid use, thus findings may not be representative of the wider population.

Autho Secondary Author(s)

Hamilton, L.S. Stone, R.W.

Title

Student attitudes toward drug testing of college athletes.

Publication

Physical Educator

Sample: College students

Key words: Attitudes, Drug testing

Design: Cross-sectional survey (questionnaire)

Publication Year

1990
Volume, Issue, Pages

$47 ; 2 ; 33-36$

Location: United States

\section{Summary}

The attitudes of 640 college students aged 18-24 were assessed by questionnaire. The sample comprised mostly non-athletes ( $n=$ 559), evenly distributed by sex and across all college years.

Students were generally supportive of drug testing in college, with $90 \%$ of subjects stating that it was the right of the college to require drug testing of intercollegiate athletes. Students also indicated that both amateur and professional athletes have a duty not to use illegal drugs. There was a tendency for student athletes to be more permissive of drug use by professional athletes than student nonathletes. With regard to the perceived benefits of drug use, $14 \%$ of student athletes stated that drug use was an acceptable means of building muscles and $20 \%$ believed it made them more attractive to the opposite sex. In both cases, a smaller percentage of nonathletes recognized the benefits of steroid use.

This is a short paper providing interesting background reading on the development of drug testing procedures in US colleges but lacking in-depth analysis or detailed discussion of findings. 
$\begin{array}{ll}\text { Author } & \text { Secondary Author(s) } \\ \text { Issari, P. } & \text { Holman-Coombs, R. } \\ \text { Title } & \\ \text { Women, drug use and drug testing. } & \text { The case of the intercollegiate athlete. } \\ \text { Publication }\end{array}$

Publication

Journal of Sport and Social Issues

Publication Year

1998

Design: Cross-sectional survey (questionnaire/interview)

Theory(s) applied: Socialisation
Volume, Issue, Pages

22; $2 ; 153-169$

Location: United States

Key words: Attitudes, Gender, Drug testing

\author{
Theory(s) applied: Socialisation
}

\title{
Summary
}

The attitudes and behaviours of 500 intercollegiate athletes with regard to drug use and drug testing were assessed by questionnaire. In depth interviews were conducted with a further 57 students to provide qualitative insight into questionnaire findings. The primary focus of this paper was to compare responses by gender and, in particular, to examine the female perspective on drug use and testing, a topic which has received little coverage in existing literature.

Females were significantly less likely than men to consider drug testing an invasion of privacy $(P<0.01)$, a violation of civil rights $(P<0.001)$ or unethical $(P<0.001)$. Females were more likely to support mandatory drug testing for all intercollegiate and professional athletes. Female athletes were more likely to support the banning of athletes who tested positive for illegal substances, whilst males believed that athletes should be given 2 or more chances following a positive test before being banned. Across both sexes, athletes agreed that testing should be conducted for steroids, amphetamines, barbiturates and tranquilizers. There was general agreement that testing should not be conducted for alcohol, prescription drugs or tobacco. The authors comment that prevention and intervention efforts need to target shared and distinct characteristics of men's and women's attitudes and behaviour towards drug use and testing.

Results from this study are generated from a sample also used by Coombs and Coombs (1991) and Coombs and Ryan (1990).

Author

Secondary Author(s)

Kersey, R.D.

Title

Anabolic androgenic steroid use by private health club / gym athletes.

Publication

Journal of Strength and Conditioning Research

Publication Year

1993
Volume, Issue, Pages

7; $2 ; 118-126$

Location: United States

Sample: Gym users

Design: Cross-sectional survey (questionnaire)

Key words: Knowledge, Prevalence, Anabolic steroids

Theory(s) applied: N/A

Summary

The study surveyed 185 private health club / gym users for use and knowledge of anabolic steroids, using a 22-item questionnaire. Responses of self-reported users and non-users are compared.

Forty eight percent of users reported they were 'very knowledgeable' on the subject of steroids compared to just $12 \%$ of non-users No objective method of assessing knowledge was used. The primary source of knowledge on anabolic steroids was 'magazines / trade literature' for non-users and 'lifting partners' for users. Eighty-four percent of users and 69\% of non-users felt that anabolic steroids could improve athletic performance. Fourteen percent of users compared to $46 \%$ of non-users indicated that less than $10 \%$ of people they knew were using steroids. Forty four percent of users and $17 \%$ of non-users reported that between $50-80 \%$ of people they knew were using steroids.

The study provides a mostly descriptive analysis of anabolic steroid users / non-users based upon the study of a specific population. Little information is reported with regard to attitudes or beliefs about steroid use or steroid users. Study findings are not discussed in great depth. 
Kersey, R.D

\title{
Title
}

Anabolic-androgenic steroid use among California community college student athletes.

\section{Publication}

Journal of Athletic Training

Sample: College athletes

Key words: Prevalence, College athletes, Anabolic
Volume, Issue, Pages $31 ; 3 ; 237-241$

Location: United States

Summary

The paper primarily focuses on prevalence of anabolic steroid use in community college athletes, with descriptive comparisons of users and non-users. The sample comprised 1185 male and female subjects, aged 17-39, assessed for steroid use and knowledge using a 27 item questionnaire. Information regarding subjects' attitudes to steroid use is limited.

Prevalence of steroid use was $4.2 \%$ for males and $1.2 \%$ for females. Forty-eight percent of users compared to just $15 \%$ of non-users considered themselves to be 'very knowledgeable' on steroid related matters. Lifting partners and fellow athletes were the primary sources of knowledge for steroid users, whilst non-users were more likely to be informed by coaches or instructors. Users tended to over-estimate the rate of steroid use amongst peers whilst non-users tended to under-estimate this figure.

Subjects' perceived knowledge was not corroborated by an objective measure of actual knowledge. The survey did not explore athletes' attitudes towards steroid use in depth. Problems associated with use of questionnaires to collect data on sensitive or controversial topics should be acknowledged in interpretation of findings.

\author{
Author Secondary Author(s) \\ Laure, P. $\quad$ Lecerf, T., Friser, A., Binsinger, C. \\ Title
}

Drugs, recreational drug use and attitudes towards doping of high school athletes.

Publication

International Journal of Sports Medicine

Publication Year

2004

Sample: High school athletes
Volume, Issue, Pages

$25 ; 2 ; 133-138$

Key words: Attitudes, Recreational drugs, Doping

Theory(s) applied: N/A

Summary

Data were gathered from 1459 French high school athletes (average age 16 years) by questionnaire assessing drug use, attitudes towards doping and psycho-sociological factors associated with the use of drugs and doping agents.

Four percent of subjects stated they had used doping agents at least once, with higher prevalence in boys than girls. Drug use also increased with age and level of competition. Seven percent stated that doping was not always hazardous to health, especially amongst boys, athletes over 18 years of age, and those who had used doping practices previously. Sixty-eight percent of athletes believed that doping is effective in improving sport performance and $21 \%$ reported that refusal to use doping practices meant losing all chances of becoming a great champion. Twenty-seven percent of subjects indicated that doping could be practised without any health risks if supervised by a physician. Athletes who admitted using doping agents were more likely to have bad relations with their parents, feel disliked by classmates and feel unhealthy.

Threats to reliability associated with use of questionnaires, especially with young people and on issues of illegal substance use, should be considered when interpreting these results. 

Author
Secondary Author(s)
Laure, $P$.
Reinsberger, $\mathrm{H}$.
Title
Doping and high-level endurance walkers. Knowledge and representation of a prohibited practice.
Publication
Publication Year
Volume, Issue, Pages
The Journal of Sports Medicine and Physical Fitness
1995
$35 ; 3 ; 228-231$

Sample: Elite/national athletes

Design: Cross-sectional survey (open-ended questionnaire) Location: France

Key words: Motives, Knowledge, Doping

Theory(s) applied: N/A

Summary

The study investigated knowledge and attitudes of doping by self-report questionnaire in a predominantly male sample of 102 high-level endurance walkers. Included in the questionnaire were items relating to circumstances in which doping may be deemed more or less excusable, assessment of potential health risks and incidence of doping in endurance walking and other sports.

The most frequently cited motives for engaging in doping were to increase performance, wish to win and for financial reasons. Subjects were unclear as to whether or not existing sanctions for doping were adequate or acted as a deterrent, but indicated that tests for doping should be conducted. Subjects were familiar with anabolic androgenic steroids and amphetamines as doping agents but did not show extensive knowledge of other possible substances. Forty-one percent of those surveyed indicated that they were aware of the use of doping agents in endurance walking.

The article lacks clarity; perhaps as a consequence that English is not the author's first language. It should also be noted that the response rate to questionnaires was quite low, just $54 \%$.

\author{
Author Secondary Author(s) \\ Laure, P. Thouvenin, F., Lecerf, T. \\ Title \\ Attitudes of coaches towards doping. \\ Publication
}

Journal of Sports Medicine and Physical Fitness

Design: Cross-sectional survey (postal questionnaire)

Publication Year

2001

Volume, Issue, Pages

41; $1 ; 132-136$

Sample: Coaches

Theory(s) applied: N/A

Key words: Attitudes, Prevention, Education

Summary

The attitudes of 260 newly qualified coaches concerning issues of doping and its prevention in sport were assessed by postal questionnaire. Subjects were mostly male, aged 23-31.

Sixty-eight percent of coaches believed that doping was a form of drug addiction, and $70 \%$ stated that most sporting records had been broken due to use of doping practices. Approximately one third of respondents suggested that an athlete who declines doping has little chance of succeeding at the highest level, with a further $10 \%$ stating that doping could be practised without hazard to health if supervised by a physician. Eighteen percent of coaches reported that they had been confronted with a request for information or for issue of doping substances within the last 12 months. The majority believed that they have a role to play in doping prevention, but felt they were not sufficiently trained to take action. Recommendations are made to alter the attitudes of coaches on doping and through education improve their capacity to take preventive action.

The attitudes expressed above represent those of a particular population of the Lorraine region in France, thus are not representative of the coaching population as a whole. The voluntary nature of participation in a postal survey introduces the possibility of response bias. 


\author{
Author Secondary Author(s) \\ Laure, $\mathrm{P}$. Binsinger, $\mathrm{C}$., Lecerf, T. \\ Title
}

General practitioners and doping in sport: Attitudes and experience.

Publication

British Journal of Sports Medicine
Publication Year

2003
Volume, Issue, Pages $37 ; 4 ; 335-338$
Sample: General Practitioners

Design: Cross-sectional survey (telephone interview)

Location: France
Theory(s) applied: N/A

Key words: Attitudes, Experience, Knowledge

Summary

Attitudes to, and knowledge of, doping in sport were examined for 202 French General Practitioners by telephone interview. A 40 -item questionnaire was used to gather information on knowledge of doping agents, contact with doping on an everyday basis and commitment to doping prevention.

Over $80 \%$ of subjects acknowledged that doping is a public health problem and constitutes a form of drug addiction. GP's were generally lacking in knowledge regarding the various types of doping agent, naming only 2.6 of the 13 classes of substances on the IOCs prohibited list. Seventy-three percent of GPs confirmed that they possessed the list of banned substances, but all owned a copy of the Vidal dictionary which contains a copy of this list. Thirty-seven percent of GP's indicated that they had been faced with a request for information about doping agents in the previous 12 months. Eighty-two percent stated that current methods of preventing doping were ineffective, and that the primary reasons to combat doping in sport were to protect athletes' health and uphold ethical values in sport. Eighty-nine percent of GP's believed that they had a role to play in doping prevention, but the majority considered themselves poorly trained to take action.

Findings should be interpreted with caution due to use of telephone interview technique which may introduce a source of bias.

\author{
Author Secondary Author(s) \\ Laure, P. Kriebitzsch-Lejeune, A.
}

Title

Retail pharmacists and doping in sports: Knowledge and attitudes. A national survey in France.

Publication

Publication Year

Science and Sports

2000

Volume, Issue, Pages

Sample: Retail pharmacists

Design: Cross-sectional survey (telephone interview)

$15 ; 3 ; 141-146$

Key words: Attitudes, Knowledge, Education

Theory(s) applied: N/A

Summary

One hundred and ninety eight retail pharmacists were questioned with regard to their willingness to engage in doping prevention efforts, and whether they possess the skills and attitudes necessary to do so. Data collection was by telephone interview following a scripted protocol.

Pharmacists lacked knowledge on prohibited substances, naming on average 1.7 of the 8 classes of methods and substances on the IOC prohibited list. Eighteen percent of pharmacists were not aware that a list of prohibited substances could be found in the Vidal dictionary. Eighty eight percent of pharmacists acknowledged doping as a public health problem and 69\% percent indicated it was a form of drug addiction. Pharmacist were most likely to report that team members, doctors and drug dealers where supplying doping agents. The majority of pharmacists $(91 \%)$ considered that they had a role to play in doping prevention, but most of them believed they were poorly or very poorly trained to do so. Seventy-three percent of pharmacists reported that current methods for preventing doping were ineffective. Suggestions are made as to how pharmacists could be better educated to fulfil their role in tackling doping.

Findings should be interpreted with caution due to use of telephone interview methods, which may introduce a source of bias. 


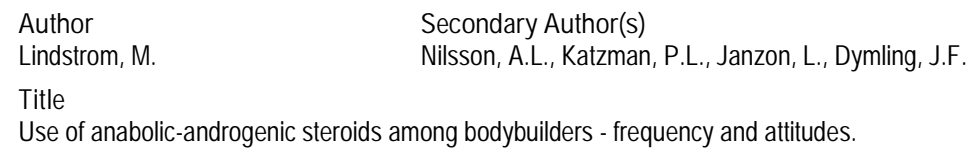

Publication Year 1990

Design: Cross-sectional survey (questionnaire)
Volume, Issue, Pages $227 ; 6 ; 407-411$

Location: Sweden

Sample: Bodybuilders

Theory(s) applied: N/A

Key words: Frequency, Attitudes, Anabolic steroids

Summary

One hundred and thirty eight bodybuilders participated in this study to assess frequency of, and attitudes toward, anabolic steroid use. Also measured was training frequency, body mass index, blood pressure, socio-economic status, side effects and medical knowledge. Results of steroid users and non-users were compared.

Thirty-eight percent of respondents reported using steroids at some point. Users combined parenteral and oral methods to administer the drugs most frequently. Steroid users were more likely to be training for competition than non-users and showed significantly greater knowledge than non-users. Non-users were more likely to be involved in body building to improve well-being or increase muscle volume. Ninety-four percent of all respondents considered anabolic steroids to be dangerous; for steroid users this was only the case if consumed in high doses. Thirty nine percent of current steroid users indicated that they planned to continue usage in the future.

This is a short paper that does not analyse or discuss attitudes toward steroid use in great detail.

Author

Maharaj, V.R.

Title

Knowledge, attitudes, and practices of anabolic steroid usage, among gym users in Trinidad.

Publication

West Indian Medical Journal

Publication Year

2000

Volume, Issue, Pages

$49 ; 1 ; 55-58$

Sample: Recreational athletes

Design: Cross-sectional survey (questionnaire)
Location: West Indies

Key words: Attitudes, Knowledge, Prevalence

Theory(s) applied: N/A

\section{Summary}

One thousand and sixty two recreational gym users completed a questionnaire to determine knowledge, attitude and practices regarding anabolic androgenic steroids. The sample was evenly distributed by sex ( $52 \%$ male) with approximately $50 \%$ of subjects aged $20-29$

Prevalence of lifetime steroid use was $2.9 \%$ (95\% Cl 2.0-4.1), with significantly greater usage amongst males than females. The number of correct responses to questions regarding knowledge of steroids ranged from 0-17, with a median of 7 . Knowledge of anabolic steroids was greater amongst males and steroid users. Sixty-six percent of respondents indicated that anabolic steroids should be banned in competition, $6.4 \%$ that steroids should be allowed in competition and $27 \%$ expressed no opinion on this matter. Sixty-nine percent reported that steroids should only be available with a prescription. The most frequently cited reason for steroid use was to improve physical appearance.

The low rate of reported steroid use may indicate a degree of underreporting. Results tables are not presented which is another limitation of this article. 
Elite athletes' perceptions of the use and regulation of performance enhancing drugs in the United Kingdom.

\section{Publication}

Journal of Legal Aspects of Sport

Sample: Elite athletes
Volume, Issue, Pages 9; $1 ; 43-51$

Location: United Kingdom

Key words: Perceptions, Attitudes, Elite athletes

Theory(s) applied: N/A

Summary

The paper addresses the perceptions of 12 elite UK fencers on the issue of performance enhancing drug use. In particular, the impact of the case of Diane Modahl, a British athlete banned but subsequently cleared of a doping offence, upon the attitudes of subjects regarding drug use and testing are explored. Participants' knowledge and perceptions of drug testing and the scientific rationale which support it were assessed through a semi-structured interview.

Subjects generally had poor knowledge of the effects of anabolic steroids and other performance enhancing drugs. The majority of respondents indicated that their primary source of information on drugs were newspaper reports. Moreover, subjects lacked faith in the official sources of information on doping, such as the Amateur Fencing Association, and preferred to seek advice from other athletes, doctors or pharmacists if necessary. All participants reported that they did not have confidence in testing procedures, and without prompting referred to the Diane Modahl case as the main reason for this. A number of subjects expressed concerns about testing positive for substances, such as caffeine or codeine, which can be found in 'over-the-counter' products. Despite a general cynicism and distrust of drug testing, most participants believed that giving athletes the freedom to take performance enhancing substances should be resisted.

The article is qualitative, thus findings cannot be analysed using statistical methods or generalised to other populations.

Autho

Secondary Author(s)

Melia, P.

Pipe, A., Greenberg, L.

Title

The use of anabolic-androgenic steroids by Canadian students.

Publication

Clinical Journal of Sport Medicine

Publication Year

1996

Design: Cross-sectional survey (questionnaire)
Volume, Issue, Pages

$6 ; 1 ; 9-14$

Location: Canada

Sample: High school students

Theory(s) applied: N/A

Key words: Attitudes, Knowledge, Anabolic steroids

Summary

Reports on data from the Canadian Centre for Drug Free Sport (CCDS) National Survey on Drugs in Sport. A Forty-two item questionnaire was completed by 16169 school students aged 11-18, drawn randomly from five Canadian regions. The aim was to assess prevalence of use of performance enhancing drugs, particularly anabolic steroids, and associated knowledge and attitudes.

Overall prevalence of steroid use was $2.8 \%$, of which $1.5 \%$ used to improve performance and $1.3 \%$ to alter body image. Prevalence was greater for males and increased with age and involvement in competitive sport. Twenty-five percent of users reported they injected these drugs; of that group $29 \%$ indicated they had shared needles. Twenty-nine percent of users, compared to just $6 \%$ of nonusers, believed that steroid use would not harm them. Seventy-four percent of students strongly agreed that using drugs to do better in sport was cheating. The authors refer to a 'chemical intervention mentality', such that students reported using a number of substances (caffeine, diuretics, painkillers, steroids) to improve sporting performance. It is noted that efforts to counter anabolic steroid use must employ strategies that target not only those using to enhance performance but also those using to alter body-image.

Due to the legal and social constraints surrounding anabolic steroid use, there is a strong possibility of underreporting of there usage. 
Vocabularies of motive for illicit steroid use among bodybuilders.

Publication

Publication Year

2002
Volume, Issue, Pages $55 ; 5 ; 695-708$

Sample: Bodybuilders

Design: Ethnography (interview/observation)

Location: United Kingdom

Key words: Vocabularies of motive, Embodiment

Theory(s) applied: Self-fulfilment, Neutralisation

Summary

Using qualitative methods, the paper explores the reasons given by bodybuilders for their use of anabolic steroids from a sociological perspective. The analysis is informed primarily by the work of Weinstein (1980), Scott and Lyman (1968) and Sykes and Matza (1957). Respondents espoused three main justifications for their own and/or other bodybuilders' illicit steroid use; namely: selffulfilment accounts, condemnation of condemners and a denial of injury. Accordingly, steroid use was justified as a means to an end, distinct from recreational drug use. Observers that passed negative judgements on those using steroids were rejected on the basis that condemners were likely to be in poor physical condition, engaged in more common risk practices (e.g. smoking, drinking alcohol) or were ignorant about steroids. Lastly, steroid use was justified on the grounds that it was not injurious to health, such that usage was informed by a collective body of knowledge held by experienced members of the bodybuilding community. Guided by this knowledge, parameters that distinguished between 'safe' and 'risky' steroid practices were set.

The framework utilised in this paper examines steroid users' perspectives as social constructions, wherein differences in subjects' gender, socio-economic status or ethnicity are not considered.

\author{
Author Secondary Author(s) \\ Naylor, A.H. Gardner, D., Zaichkowsky, L. \\ Title
}

Drug use patterns among high school athletes and nonathletes

Publication

Publication Year

2001

Design: Cross-sectional survey (questionnaire)
Volume, Issue, Pages $36 ; 144 ; 627-639$

Location: United States

Sample: High school students

Theory(s) applied: N/A

Key words: Athletes/Non-athletes, Recreational drugs

$$
\text { Theory(s) applied. N/A }
$$

Summary

The primary aim of this study was to examine recreational and ergogenic drug use patterns in 1515 high school students, using a 150 item questionnaire. Researchers sought to identify differences in usage between athletes and non-athletes. Data were also gathered on students' perceptions of a drug education and prevention programme run by the Massachusetts Interscholastic Athletic Association (MIAA)

Analysis revealed that athletes were less likely to use cocaine, psychedelic drugs and smoke cigarettes than non-athletes. There were no differences in usage of anabolic steroids or androstenedione between athletes and non-athletes. Sixty-eight percent of athletes stated that they were aware of the MIAA's Chemical Health Eligibility Rule which prohibited the use of recreational or ergogenic drugs during the athletic season. Thirty-eight percent of students reported having violated this rule; only $12 \%$ of these students stated they had been punished by school officials. Seventy one percent of athletes believed that some of their team-mates had violated this ruling. Thirty one percent expressed interest in drug education initiatives provided by the athletic department, but only $52 \%$ stated they would be prepared to undergo random drug testing.

The study population was gathered solely from the Massachusetts region, thus the school and sport cultures described are bound to that locality. Generalising these findings must be done with caution. 


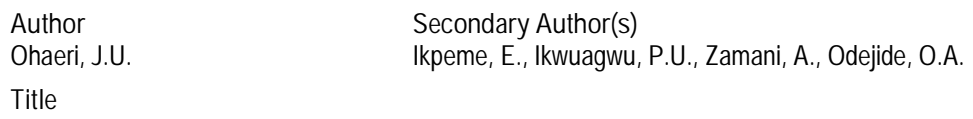

Two-hundred and fifty professional Nigerian athletes were surveyed to ascertain use and awareness of anabolic steroids and other drugs. Subjects indicated type of sport and level of participation, perception of muscle build and satisfaction with body shape.

Only 3 respondents (1.2\%) reported previous use of anabolic steroids. Knowledge of possible side effects of steroid use was lacking, such that over $80 \%$ of athletes were not aware that steroid use could cause tendon injuries, acne and gyneaecomastia. Eight percent suggested that team-mates encouraged use of anabolic steroids, while $4 \%$ stated that they admired the achievements of sportspeople who used steroids. Five subjects admitted that they had trafficked drugs previously with a further 13 reporting they had been approached to serve as a drug courier.

The possibility of under-reporting, due to the illegal nature of the practices explored in this study, is a limitation of these findings.

\author{
Author Secondary Author(s) \\ Olrich, T.W. Ewing, M.E.
}

Title

Life on steroids: Bodybuilders describe their perceptions of the anabolic-androgenic steroid use period.

Publication

The Sport Psychologist

Publication Year

1999

Volume, Issue, Pages

$13 ; 3 ; 299-312$

Sample: Bodybuilders

Design: Qualitative survey (interview)

Key words: Perceptions, Social Status, Dependence Theory(s) applied: N/A

Summary

In depth interviews were conducted with 10 experienced bodybuilders who had previously or were currently using anabolic androgenic steroids (same sample drawn from in the study by Orlich, 1999). Subjects discussed their experience of the steroid use period, with particular reference to reasons for initiating use and perceptions of there psychological and physical effects.

Nine out of ten subjects described their experience in a very positive manner. Subjects reported physical, psychological and social benefits of steroid use, including increased muscle mass, improved confidence and greater social status and peer recognition. Three prominent themes emerged when examining the reasons for initiating steroid use. These were: a feeling that they were at a plateau in their training, frustration at watching others progress while they did not and curiosity as to their effects. Five out of ten subjects stated that their decision to try steroids was a difficult one, characterised by feelings of guilt and/or compromised morals. Eight subjects commented that to be competitive at a high level in bodybuilding steroids and other drugs were a must. All subjects acknowledged the possibility of psychological dependence on steroids.

The low number of subjects means that results should not be generalised to the wider population. The fact that the interviewer was personally acquainted with subjects introduces the possibility of bias in reporting. 
Title

Perceptions of benefits and losses associated with the use and discontinuance of anabolic-androgenic steroids among male

\title{
Publication
}

Journal of Personal and Interpersonal Loss

Publication Year

1999

Design: Qualitative survey (interview)
Volume, Issue, Pages $4 ; 3 ; 231-242$

Location: United States

Sample: Bodybuilders

Theory(s) applied: N/A

Key words: Perceptions, Dependency, Masculinity

Summary

Drawing on data collected by in-depth interviews with 10 experienced bodybuilders already discussed by Olrich and Ewing (1999), the article describes perceived benefits of steroid use and explores in greater detail the development of psychological dependency associated with prolonged steroid use. Findings are discussed with reference to the work of Mishkind et al. (1987), which outlines a framework to understand the link between steroid use, the mesomorphic body type and cultural views of masculinity.

All subjects agreed that there is a strong psychological dependency involved with steroid use. Dependence was experienced in a two fold manner: firstly through a desire to maintain the benefits accrued through steroid use and secondly an urge to avoid the negative consequences associated with loss of muscle that occurred when steroid use was terminated. Also important were social gains associated with increased muscle size, such as increased peer recognition and social status. The desire to maintain this level of recognition also plays a role in developing dependence upon steroids. The author contends that termination of steroid use not only results in loss of muscle mass but also peer recognition, self-confidence and social status. The work of Mishkind et al (1987) asserts that the mesomorphic body type has become the embodiment of masculinity, thus bodybuilders who lose mesomorphic characteristics in the process of terminating steroid use may also suffer a loss in perceived masculinity.

\author{
Author Secondary Author(s) \\ Ozdemir, L. N Nur, N., Bagcivan, I., Bulut, O., Sumer, H., Tezeren, G. \\ Title
}

Doping and performance enhancing drug use in athletes living in Sivas, mid-Anatolia: A brief report.

Publication

Journal of Sports Science and Medicine

Publication Year

Volume, Issue, Pages

Sample: Elite/amateur athletes

2005

$4 ; 248-252$

Key words: Attitudes, Prevalence, Doping

Design: Cross-sectional survey (questionnaire/interview)

Location: Turkey

Summary

The study aimed to establish the prevalence of, and reasons for, doping drug use amongst adults and adolescents (age range 15-34 years) in the Turkish city of Sivas. Data were gathered from 433 athletes and 450 non-athletes using a 24 item questionnaire. Approximately $20 \%$ of athletes competed at National level.

Overall prevalence of doping drug use was $8.0 \%$, with significantly higher incidence in athletes (14.5\%) compared to non-athletes $(1.8 \%)$ and in males compared to females. Bodybuilders reported the highest usage of doping agents. The most frequently cited reasons for drug use were to improve physical condition, to solve weight problems, to recover from injury or to increase chances of selection for a team. Compared to non-users, drug users were more likely to report that their competitors were also using drugs, that doping was necessary for success and that doping agents should be legalised. A small percentage (3.2\%) of users indicated that they had administered excessive doses of a doping agent, whilst more than half (52\%) were unaware of some potential side-effects associated with drug use.

Given that all subjects were drawn from the same city, researchers should be cautious in making generalisations about the findings reported in this article. This short paper is lacking in detailed analysis and discussion of findings, possibly because English is not the authors' first language. 
$\begin{array}{ll}\text { Author } & \text { Secondary Author(s) } \\ \text { Paccagnella, M. } & \text { Grove, J.R. }\end{array}$

Title

Drugs, sex and crime in sport: An Australian perspective.

Publication

Journal of Sport and Social Issues
Publication Year

1997
Volume, Issue, Pages

$21 ; 2 ; 179-188$

Location: Australia

Sample: University students

Design: Cross-sectional survey (questionnaire)

Key words: Perceptions, Media, Stigmatization

Theory(s) applied: N/A

\section{Summary}

The impact of different types of controversial publicity (steroid use, criminal activity or sexual stigma) on subjects' perceptions of selected high-profile sports performers was investigated. Data was collected by questionnaire from 106 undergraduate Sport Science students. Subjects rated named sports stars (e.g. Ben Johnson and Martin Vinnecoomb as examples of steroid users) on 11 dependent variables assessing attitudes and ascribed personality traits.

Athletes associated with drug use were perceived as less honest and less rule orientated than performers subject to other forms of publicity. They were also viewed as lacking in self control and uncaring, especially by male subjects. This was believed to be a result of a tendency toward conservatism within the sporting institution and the expectation of exemplary behaviour from high profile sports stars. Athletes who had been sexually stigmatized were generally viewed more positively than the other two groups. The paper highlights the impact of gender and sub-cultural values in the formulation of attitudes toward stigmatized athletes.

Findings are limited by the use of subjects closely tied to the sporting institution and the inclusion of only two stimulus performers within each category of stigma.

$\begin{array}{ll}\text { Author } & \text { Secondary Author(s) } \\ \text { Pan, D.W. } & \text { Baker, J.A. } \\ \text { Title } & \end{array}$

Perceptual mapping of banned substances in athletics. Gender and sport defined differences.

\section{Publication}

Journal of Sport and Social Issues

Sample: Student athletes

Key words: Perceptual maps, illicit drugs
Volume, Issue, Pages

$22 ; 2 ; 170-182$

Location: United States

\section{Summary}

The study examined student-athletes perceptions of 16 banned substances, using a multi-dimensional-scaling approach. Subjects rated each substance on a 7 point Likert scale $(1=$ attribute not related to substance, 7 = attribute strongly related to substance) for each of 20 selected attributes, which included social factors, side effects, positive effects and relevance to athletic performance. Responses were compared by gender and participation in ether contact or non-contact sport, with the intention to identify substances to which student-athletes are vulnerable.

Strong preferences were identified for alcohol and caffeine in all subjects. Marijuana, speed, and LSD were popular amongst male students and amphetamines and morphine among female students. Differences were also evident for type of sport, with marijuana, cocaine and heroin preferred amongst contact sport participants, whilst marijuana and speed were most popular for those in non-contact events. Male athletes were well informed about the functions and dysfunctions of anabolic steroids. The author comments that this is indicative of the effect of drug education programmes amongst university students, but questions the extent to which they have deterred use because college athletes were still vulnerable to use.

Other factors that effect drug use, such as age, socio-economic status or competitive level were not included in the analysis. 


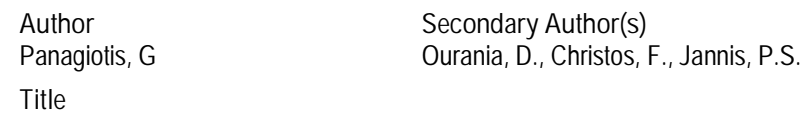

Knowledge on and attitudes of doping in sport, of young trainees in internal and general-familial medicine.

Publication

Pharmacologyonline

Sample: Trainee doctors

Key words: Attitudes, Knowledge, Doctors

Design: Cross-sectional survey (questionnaire)

2006

2; $1-5$

Location: Greece

\section{Summary}

This article presents the findings of a survey regarding knowledge and attitudes of doping in sport in a sample of 123 young trainees in internal and general familial medicine in Greece. The sample comprised $83 \%$ males and the mean age was $28.3 \pm 3$ years.

This study highlighted a concerning lack of knowledge in this sample of trainee doctors. Only $25 \%$ of respondents had heard of the WADA/IOC banned lists and only $5.7 \%$ possessed knowledge of the laboratory control procedures. It is worrying to note that the majority (99\%) questioned declared that newspapers were their main source of knowledge relating to doping, rather than their medical studies. Furthermore, $87 \%$ felt under-trained in practicing sports medicine with only $5.7 \%$ referring to blood doping as a prohibited doping method. Despite their rudimentary knowledge in this field, nearly half of those surveyed (48\%) considered the current methods of preventing doping in sport as ineffective.

The generalisability of this study is questionable given the sample comprised entirely of doctors from one hospital in Greece. Furthermore, the questionnaire used to assess knowledge and beliefs had not undergone a validation process.

Author

Peretti-Watel, P.

Title

Attitudes toward doping and recreational drug use among French elite student-athletes.

Publication

Sociology of Sport Journal

Sample: Elite athletes

ation Year

2004

Volume, Issue, Pages

$21 ; 1 ; 1-17$

Location: France

Key words: Attitudes, Correlates, Socioeconomic status Theory(s) applied: Self-fulfilment, Habitus

Summary

Examined attitudes towards doping, their correlates and their relationship with cigarette, alcohol and cannabis use among 458 French elite student athletes. Cluster analysis was used to compare characteristics found between groups of athletes who expressed similar attitudes. Findings were interpreted from a sociology of deviance perspective, utilising concepts of 'neutralisation', 'positive deviance' and self-fulfilment.

Over $90 \%$ of all athletes reported that doping was dishonest, unhealthy and/or hazardous because of sanctions. Three clusters of subjects were identified: those that considered doping as both dangerous and useless, those that viewed doping as dangerous but efficient in improving performance and those that regarded doping as a dangerous but necessary adjunct to sporting and nonsporting achievement. Males and older athletes were over-represented in the latter two clusters. Other factors associated with a positive attitude towards doping were lower personal and parental academic achievement and greater involvement in sporting practice (assessed by number of hours per week spent in sporting activity). The authors conclude that athletes who engage in doping behaviour do so in pursuit of legitimate goals with illegitimate means but justify their behaviour with a legitimate rationale. 


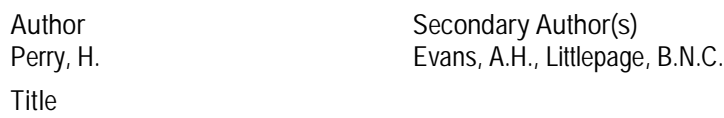

Publication Year 1994

Volume, Issue, Pages $5 ; 1 ; 15-17$

Design: Cross-sectional survey (questionnaire)

Location: United Kingdom
Sample: General Practitioners

Key words: Views, Anabolic steroids
Theory(s) applied: N/A

\section{Summary}

This short paper reports on questionnaire data gathered from 103 General Practitioners. Questionnaire items related to the number of steroid users seen in practice, tests and services offered to users and GP's confidence in their ability to counsel users.

The majority of respondents indicated they would be willing to offer steroid users blood pressure (91\%) and liver function tests (76\%) but fewer were prepared to offer kidney tests (59\%) and blood counts (57\%). Only 63\% of GP's were aware of a needle exchange scheme operating in their local area. Seventy two percent stated they would advise users on harm minimisation procedures, such as safe injecting methods. Only $34 \%$ of GP's had confidence in their ability to counsel users.

Results are discussed only briefly, with reference to the complex relationship that has developed between steroid users and the medical community and issues regarding overuse of blood testing.

\section{Author} Secondary Author(s)

Peters, R.J. Adams, L.F., Barnes, J.B., Hines, L.A., Jones, D.E., Krebs, K.M.A., Kelder, S.H.

Title

Beliefs and social norms about ephedra onset and perceived addiction among college male and female athletes.

Publication

Substance Use and Misuse

Sample: College athletes

Key words: Beliefs, Addiction, Ephedra

\section{Summary}

The beliefs and norms of 43 college athletes (13 males, 30 females) regarding use of ephedra were assessed by qualitative interview. Informed by the Theory of Planned Behaviour, interviews sought to explore subjects' beliefs regarding reasons for ephedra use, feelings towards users, duration of use, indicators of addiction, risks of use and barriers to quitting. Differences in response are analysed by gender.

Key factors related to personal ephedra use were performance enhancement and coach or peer encouragement for males and for weight loss or to increase energy levels for females. Both males and females generally believed that using ephedra was 'normal' and I or 'acceptable'. One subject, for example, stated "I think everybody does it so it's ok" whilst another reported "If it helps you win then its ok". Episodes of eccentric behaviour, such as "you shake a lot" or "you tend to act wiry" were reported as signs of addiction, whilst routine use was the most important factor in determining addiction. For females, the most frequently cited barrier to desisting ephedra use related to appearance, such as increased weight. Both males and females indicated that effects on athletic performance and lack of education were barriers to quitting usage.

The sample size was small, unevenly distributed by gender and comprised solely of college athletes, thus findings cannot be generalised readily. 
$\begin{array}{ll}\text { Author } & \text { Secondary Author(s) } \\ \text { Pope, H.G. } & \text { Kanayama, G., Ionescu-Pioggia, M., Hudson, J.L. }\end{array}$

Title

Anabolic steroid users' attitudes towards physicians.

Publication

Publication Year

1999

Design: Cross-sectional survey (questionnaire/interview)
Volume, Issue, Pages 99; 9; 1189-1194

Location: United States

Sample: Weight-lifters

Theory(s) applied: N/A

Key words: Attitudes, Physicians, Anabolic steroids

Summary

The study used interviews and questionnaires to assess the attitudes of 43 anabolic steroid users and 37 non-users, with regard to their level of trust in the knowledge and advice provided by physicians. All subjects were male and experienced weight lifters

Results supported the researchers hypotheses that subjects would give physicians high ratings on knowledge of general health and conventional drugs but much lower ratings on knowledge of anabolic steroids. Steroid users rated physician knowledge significantly lower than non-users. As a source of knowledge on steroids, users scored physicians as no more reliable than their friends, internet sites or the person who had sold them the drugs. Forty percent of anabolic steroid users trusted information from their drug supplier at least as much as they trusted information from their physician. Steroid users were also more inclined to disclose their use of steroids to male friends, girlfriends or spouses than any physician they had seen. The author asserts that physicians must be more thoroughly educated about anabolic steroids and maintain a degree of suspicion when evaluating male athletes, if this level of distrust is to be reversed.

The small sample size and possibility of selection and reporting bias demand that these results should be interpreted with caution.

$\begin{array}{ll}\text { Author } & \text { Secondary Author(s) } \\ \text { Salva, P.S. } & \text { Bacon, G.E. } \\ \text { Title } & \end{array}$

Anabolic steroids: Interest among parents and non-athletes.

Publication

Southern Medical Journal

\section{Publication Year}

1991
Volume, Issue, Pages $84 ; 5 ; 552-556$

Sample: General Practitioners

Design: Cross-sectional survey (postal questionnaire)

Location: United States

Key words: Inquiries, Athletes parents, Anabolic steroids Theory(s) applied: N/A

\section{Summary}

Family physicians, general practitioners and paediatricians were examined to ascertain the nature and extent of interest in anabolic steroids expressed by patients attending their clinic. A postal questionnaire was sent to 1305 physicians evenly distributed across the state of Texas. Completed surveys were returned by 517 subjects, a response rate of $40 \%$.

Fifty percent of physicians indicated that they had had at least one enquiry regarding anabolic steroids in the previous 5 years. When separated by age, enquiries were most frequent by patients aged 13-17 (59\%) and 18-25 (37\%). Twenty six percent of inquiries from the teen age group (13-17) were made by parents, all of which were related to participation in American football. The primary reason for enquiring about steroids was sports related, followed by psychosocial reasons, body-building and weightlifting. The majority of patients enquiring about steroids were white males.

The validity of findings may be compromised by the retrospective nature of data collection, which is dependent upon subjects' accurate recall of events. The low response rate also limits study findings. 


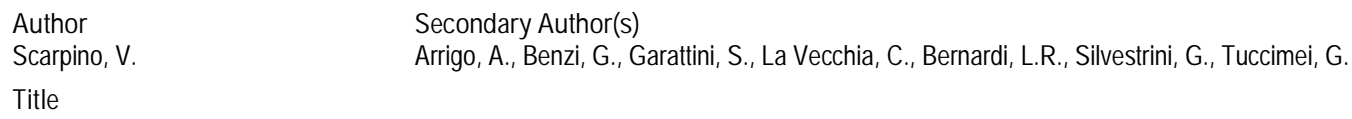

Publication Year

1990

Sample: Elite athletes, Coaches, Doctors Design: Cross-sectional survey (interview) 336; 1048-1050

Volume, Issue, Pages

Location: Italy

Key words: Attitudes, Knowledge, Prevalence

Theory(s) applied: N/A

\section{Summary}

Knowledge of, attitudes to and use of illegal drugs and other forms of doping was evaluated by interview in 1015 Italian athletes and 216 coaches, doctors and managers. The study was funded by the Italian National Olympic Committee and National Research Council.

Overall, $30 \%$ of athletes, coaches and managers and $21 \%$ of doctors indicated that athletic performance could be enhanced by use of drugs and other doping practices. More than $10 \%$ of athletes stated that amphetamines and anabolic steroids were being used frequently at national or international level. Athletes' most frequently cited reasons for using doping agents were to win in competition (63\%), improve training performance (9\%), reduce pain (6\%) and at the request of a coach (6\%). The majority of athletes believed that they had been put under external pressure to use drugs or doping practices. Three-quarters of athletes indicated that access to illegal substances was not difficult. A greater number of subjects indicated that doping was potentially harmful than stated it was efficacious in improving performance.

Findings should be interpreted with caution since the sample was identified on the basis of quotas and not individuals, thus errors and sources of bias, particularly selection bias, could have arisen.

$\begin{array}{ll}\text { Author } & \text { Secondary Author(s) } \\ \text { Schneider, D. } & \text { Morris, J. }\end{array}$

Title

College athletes and drug testing: Attitudes and behaviours by gender and sport.

Publication

Journal of Athletic Training

Sample: College athletes

Key words: Attitudes, Gender, Type of sport

Design: Cross-sectional survey (questionnaire)

Publication Year

1993
Volume, Issue, Pages $28 ; 2 ; 146-150$

\section{Summary}

Five hundred and twenty four US college athletes were assessed for their attitudes and behaviours towards a mandatory drug education and testing programme. Differences between sports and by gender were analysed. Responses were obtained from 197 athletes (38\%), participating in a range of sports including baseball, American football, basketball, lacrosse, track and field and hockey.

Fifty-seven percent of athletes claimed to have experimented with illegal substances whilst at college, but only $10 \%$ of those suggested it had been to enhance performance. Opinions were generally split as to whether or not drug testing discouraged drug use, whether penalties for drug use were severe enough or whether testing should be conducted at random. Only $17 \%$ of subjects believed that drug testing was an invasion of privacy. Across all sports, males were more likely to know a team mate using illegal substances than females. Between sports, Lacrosse players and American football players were most likely to know a team mate using illegal substances.

The article takes a generalised approach to investigating drug and alcohol use, thus specific substances or ergogenic aids are not mentioned by name. Findings may be limited by a possible selection bias associated with the use of volunteers as subjects. Factors that may influence subjects opinions, such as year of study, were not controlled for. 
$\begin{array}{ll}\text { Author } & \text { Secondary Author(s) } \\ \text { Schwerin, M.J. } & \text { Corcoran, K.J. }\end{array}$

Title

Beliefs about steroids: User vs. non-user comparisons.

Publication

Drug and Alcohol Dependence

Publication Year

1996
Volume, Issue, Pages $40 ; 3 ; 221-225$

Location: United States

Sample: Bodybuilders

Design: Cross-sectional survey (questionnaire)

Key words: Beliefs, Anabolic steroids

Theory(s) applied: N/A

\section{Summary}

The paper investigates factors associated with anabolic steroid use. The beliefs of 20 steroid users and 27 non-users are compared using the 40-item Beliefs About Steroids Scale (BASS). Subjects rated statements concerning the physical and psychological effects of anabolic steroids on a 1-4 Likert-type scale. All subjects were male university bodybuilders.

Significant differences were found between users and non-users on 35 out of 40 questionnaire items. Steroid users expressed more positive beliefs about the physical and psychological effects of anabolic steroid use. Amongst other reasons, users stated that they expected steroids to make them feel more masculine ( 3.84 vs. $2.85, P<.001)$, more confident $(3.79$ vs. $2.44, P<.001)$, a better athlete (3.74 vs. $2.48, P<.001$ ) and happier with themselves ( 3.63 vs. $1.85, P<.001)$. Findings are discussed within the context of the 'Theory of Reasoned Action', such that behavioural beliefs shape attitudes, intention and subsequent behaviour.

At the time of publication the BASS scale was still in the development stages and required further psychometric testing. Further, all subjects were experienced bodybuilders or weight lifters from the student population, thus findings must be generalised with caution.

Author Secondary Author(s)

Schwerin, M.J. Corcoran, K.J.

Title

A multimethod examination of the male anabolic steroid user.

Publication

Journal of Applied Social Psychology

Publication Year

1996

Design: Cross-sectional survey (questionnaire)
Volume, Issue, Pages

$26 ; 3 ; 211-217$

Location: United States

Sample: University students

Theory(s) applied: N/A

Key words: Perceptions, Anabolic steroids, Cocaine

Summary

The study extended the authors previous work (see Schwerin and Corcoran, 1992) to explore peoples' perceptions of the male steroid-using bodybuilder using a visual stimulus, rather than a written stimulus. As one way of fulfilling their psychology course requirements, University students were exposed to a slide presentation with a drug free body builder, a steroid using body builder, a cocaine using body builder, a cheating body builder or an athletically active individual. Following the presentation, subjects rated the character using the Steroid Perception Questionnaire (SPQ). Differences in representation of the story protagonist as measured using the SPQ were analysed according the method of presentation, either visual or written.

Similar to previous findings, in general, the steroid using bodybuilder was viewed negatively compared to their drug-free counterparts. Steroid using bodybuilders were rated poorly on constructs relating to social assertiveness, tension reduction, global positive perceptions and intelligence. However, ratings of intelligence and global positive enhancement changed for the steroid using protagonist with the change from written to visual mode of representation. Ratings were more positive after the visual mode of presentation, suggesting that visual information may mitigate negative attitudes about drug use, possible as a result of the visible physical effects apparent in this form of presentation. Caution must be taken when interpreting these findings as weak internal consistencies were noted for three of the subscales of the SPQ. 

Author
Secondary Author(s)
Schwerin, M.J.
Corcoran, K.J.
Title
What do people think of the male steroid user? An experimental investigation.
Publication
Journal of Applied Social Psychology
Publication Year
Volume, Issue, Pages
$22 ; 10 ; 833-840$

Sample: University students

Design: Cross-sectional survey (questionnaire)

Location: United States

Key words: Perceptions, Anabolic steroids, Cocaine

Theory(s) applied: N/A

Summary

The study focused on the perceptions that others have of anabolic steroid users. Subjects were provided with one of four variations of a written person description. In each case the person was either a steroid-using bodybuilder, a cocaine-using bodybuilder, a drug free bodybuilder or an athletically active individual (not involved in body-building). After reading the person description, subjects rated the story protagonist on characteristics relating to sexuality, aggression, social skills and intelligence using the 18-item Steroid Perception Questionnaire. Subjects were 276 university students.

Results indicated that subjects viewed the bodybuilding steroid-user significantly more negatively than the drug free bodybuilder or the athletically active individual. Specifically, they were seen as less intelligent, interesting, happy, confident and relaxed compared to non-using athletes. Subjects viewed a cocaine-using bodybuilder and a steroid-using bodybuilder similarly. The authors contend that education and intervention efforts should aim to distinguish steroid use from other forms of drug abuse (i.e. cocaine).

\section{Author}

Secondary Author(s)

Shields, E.W

Title

Sociodemographic analysis of drug use among adolescent athletes: Observations-perceptions of athletic directors-coaches.

Publication

Publication Year

1995

Volume, Issue, Pages

Adolescence

Design: Cross-sectional survey (postal questionnaire)

$30 ; 120$

Sample: Athletic directors / coaches

Theory(s) applied: N/A

Key words: Perceptions, Drug abuse, Athletes/non-

$$
\text { Theory(s) applied. NIA }
$$

Summary

The study examined Athletic Directors' (AD's) perception of substance abuse among student athletes and to compare this with substance use patterns of the general student body regionally and nationally. Two hundred and fifteen AD's (response rate 66\%) completed a questionnaire assessing their observations and perceptions of substance abuse amongst student athletes and the general student body separately. The article focuses on substance abuse in a broad manner, without specific reference to drug use for the purposes of performance enhancement.

The percentage of AD's who perceived the drug problem to be 'very big' or 'somewhat big' for student athletes was less than for students in the general study body for 10 out of 12 specified drugs, including alcohol, tobacco and marijuana. The perception of reduced drug use by athletes compared to other students was consistent across geographic location, size of school and racial-ethnic composition. The author asserts that this data presents a case for participation in athletics as a deterrent to drug abuse. Corroboration of findings through other methods of investigation would be necessary before this could be stated with any certainty.

A key limitation to this study is that AD's may have been unaware of, or unwilling to admit or inform on, their pupils substance use habits. Therefore, the reliability of these findings may be questionable. 
$\begin{array}{ll}\text { Author } & \text { Secondary Author(s) } \\ \text { Shirazi, A. } & \text { Tricker, R. } \\ \text { Title } & \\ \text { Current drug education policies in NCAA institutions: Perceptions of head athletic trainers. }\end{array}$

\title{
Publication
}

Journal of Drug Education

Publication Year

2005

Design: Cross-sectional survey (questionnaire)
Volume, Issue, Pages

$35 ; 1 ; 29-46$

Location: United States

Sample: Head athletic trainers

Theory(s) applied: N/A

Key words: Perceptions, Alcohol / other drug, Prevention

Summary

Three hundred and fifty three head athletic trainers (HATS) from a range of NCAA member institutions completed a web-based questionnaire regarding current athletic department alcohol, tobacco and other drug (ATOD) policies operating in their college or university.

Eighty-three percent of HATS reported having an ATOD policy in place, especially those in NCAA Division 1 compared to Divisions 2 and 3. Thirty percent of HATS indicated that ATOD courses were offered to students once a year, compared to just $1 \%$ who reported courses were offered on a monthly basis. ATOD courses generally covered topics relating to health and legal aspects of drug abuse and materials aimed at improving students' decision making skills. Programmes relating to assertiveness training, resisting peer pressure and coping with the pressures of competition were often absent. HATS across all 3 NCAA divisions expressed concerns that ATOD programmes were not offered closer to athletic or social events. HATS emphasised a need for athletic departments to develop long-term and comprehensive ATOD programmes for athletes and ensure these programmes are evaluated and updated regularly. The most frequently cited barriers to developing and evaluating ATOD courses were inadequate guidelines on policy development and financial and time constraints.

\author{
Author Secondary Author(s) \\ Somerville, S.J. $\quad$ Lewis, M. \\ Title
}

Accidental breaches of the doping regulations in sport: is there a need to improve the education of sportspeople?

Publication

British Journal of Sports Medicine

Publication Year

2005

Volume, Issue, Pages

Sample: Elite athletes

Design: Cross-sectional survey (postal questionnaire)

$39 ; 512-516$

Key words: Knowledge, Accidental doping, Education Theory(s) applied: N/A

Summary

Researchers examined elite UK athletes' opinions regarding accidental breaches of doping regulations, assessed their educational needs and explored ways of reducing this problem. One hundred and ninety six subjects from a range of sports (athletics, cycling rowing and sailing) were sent a postal questionnaire, of whom 74 completed and returned it for analysis (response rate $38 \%$ ).

Approximately $90 \%$ of respondents had received a doping education update within the last 6 months. Subjects were largely in agreement that they had received the relevant information to stop them getting in trouble and knew how to check if a particular substance was banned. However, they also indicated that they would prefer to receive more regular reminders about doping issues and authorities should do more to educate athletes on this matter. The two most frequently suggested methods of improving athletes knowledge was to increase awareness of the UK Sport website and provide regular updated lists of acceptable medicines and supplements. Athletes reported that the most common reasons for accidental breaches were inadequate labelling or changes in product composition and human error, such as lack of knowledge or laziness. The team doctor was the most popular source of information about supplements or medicines. The authors suggest that education efforts should include contingency planning for minor illnesses so that athletes avoid using over the counter medicines known to contain banned substances.

Reduced statistical power, due to low response rate, may limit findings of the present study. 
$\begin{array}{ll}\text { Author } & \text { Secondary Author(s) } \\ \text { Spence, J.C. } & \text { Gauvin, L. }\end{array}$

Title

Drug and alcohol use by Canadian university athletes: A national survey.

Publication

Journal of Drug Education

Publication Year

1996

Design: Cross-sectional survey (questionnaire)
Volume, Issue, Pages $26 ; 3 ; 275-287$

Location: Canada

Sample: University athletes

Theory(s) applied: N/A

Key words: Perceptions, Drug testing / education

\author{
Theorys) applied: NIA
}

\title{
Summary
}

The study examined prevalence of performance enhancing and recreational drug use and attitudes towards drug education and testing amongst 754 (62\% male) Canadian university athletes. Subjects were drawn from 8 universities, from a range of sports including ice hockey, football, basketball, track and field and swimming. The questionnaire used to gather data focused primarily upon drug use, with only 4 items pertaining to attitudes towards drug related issues.

Twenty seven percent of male athletes and $38 \%$ of females agreed with the statement "There is a problem of illegal drug use by Canadian athletes". Respondents generally supported random drug testing, with approximately $85 \%$ indicating that testing should be carried out. The vast majority of participants also reported that Canadian universities should provide drug and alcohol education programmes for athletes. However, only a third of all respondents indicated that the existing drug testing programme, operated by the Canadian Interuniversity Athletic Union, had been effective in deterring drug use. One in three subjects did not know whether the university offered drug education for student athletes.

A degree of caution is required in interpretation of findings, due to the self-report nature of data collection

\author{
Author Secondary Author(s) \\ Starkey, C. Abdenour, T.E., Finnane, D. \\ Title
}

Athletic trainers' attitudes toward drug screening of intercollegiate athletes.

Publication

Journal of Athletic Training

Publication Year

1994

Theory(s) applied: N/A
Design: Cross-sectional survey (postal questionnaire)

Sample: Athletic trainers

Key words: Attitudes, Drug screening

Summary

Researchers employed a 16-item questionnaire to determine the attitudes of athletic trainers towards the drug screening of athletes and how they view their role in the process. Two-hundred and eighteen surveys were collected, from an initial sample of 500 .

Respondents were predominantly male and had been certified as an athletic trainer for 17 years, on average.

Sixty-two percent of trainers indicated that their involvement in the university/college drug testing programme placed them in the dual role of being 'police' and 'counsellor'. A further $73 \%$ also stated that they did not think that they should be involved in the process of collecting urine specimen samples. Just under half of trainers felt that their involvement in the drug sreening process comprimised their rapport with athletes. Sixty-four percent of trainers stated that educational sessions relating to drug use must be reinforced by actual implementation of the drug screening process.

The paper focuses on drug and alcohol use in a general sense, thus specific reference to doping or performance enhancing drugs is not made. The authors note that there is a gender bias in the sample studied, with males over-represented compared to the national distribution. 
$\begin{array}{ll}\text { Author } & \text { Secondary Author(s) } \\ \text { Stilger, V.G. } & \text { Yesalis, C.E. } \\ \text { Title } & \end{array}$

Anabolic androgenic steroid use among high school football players.

Publication

Journal of Community Health
Publication Year

1999
Volume, Issue, Pages

$24 ; 2 ; 131-145$

Location: United States

Sample: High school football players

Design: Cross-sectional survey (questionnaire)

Key words: Knowledge, Use, Anabolic steroids

Theory(s) applied: N/A

\title{
Summary
}

Eight hundred and seventy three high school football players from 27 randomly selected schools completed a questionnaire assessing knowledge, attitudes, use and availability of anabolic androgenic steroids. The sample universe was stratified into urban, suburban and rural high schools in order to attain a comparable number of subjects from each geographical region.

No differences in anabolic steroid use were found between urban, suburban and rural schools. Forty nine percent of users reported improvement in performance as the primary reason for use, whilst $29 \%$ stated improved appearance. Off those that discontinued use, $43 \%$ did so because of adverse health effects, $28 \%$ were afraid of being drug tested and $11 \%$ said it was against their beliefs. Fifty four percent of users indicted that "I would use anabolic androgenic steroids if I knew opponents playing against me were using them" compared to just $22 \%$ of non-users. Forty-one percent of steroid users listed a physician or coach as their primary source for obtaining steroids.

Findings may be limited by the use of self-report methods of data collection. The possibility of underreporting, due to the illegal nature of the subject matter, may limit the validity of findings.

\author{
Author Secondary Author(s) \\ Striegel, $\mathrm{H}$. Vollkommer, G., Dickhuth, $\mathrm{H}$ \\ Title
}

Combating drug use in competitive sport. An analysis from the athletes' perspective.

Publication

Publication Year

Volume, Issue, Pages

The Journal of Sports Medicine and Physical Fitness

2002

$42 ; 3 ; 354-359$

Sample: Elite athletes

Design: Cross-sectional survey (questionnaire)

Location: Germany

Key words: Motives, Psychosocial factors

Theory(s) applied: N/A

\section{Summary}

The article examines psycho-sociological factors that motivate drug taking and seeks to highlight from an athletes' perspective whether or not doping in sport should be combated and which methods would be suitable in doing so. Data were gathered from 101 national and international German athletes by anonymous questionnaire.

The most frequently reported reasons for drug use were to achieve athletic success and for financial gain. Also mentioned, but to a lesser degree, were motives relating to increasing self-confidence and social recognition. Ninety-eight percent of respondents stated that measures should be taken to combat doping in sport. To achieve this aim, athletes indicated that improved methods of detection and more information on the health risks of doping were preferable to more severe punishments for drug users. Seventy-nine percent did not regard current dope testing to be sufficient. Seventy-four percent of athletes supported Government intervention in anti-doping efforts through the establishment of an anti-doping law.

The sample comprised athletes involved in individual sports most frequently, with only a small percentage (15\%) competing at professional or international level, thus some limitations are evident in the extent these findings can be generalised. 


\author{
Author \\ Terney, R. \\ Title \\ The use of anabolic steroids in high school students. \\ Secondary Author(s) \\ McLain, L.G.
}

\title{
Publication
}

American Journal of Diseases in Children

Sample: High school students

Design: Cross-sectional survey (questionnaire)

Publication Year

1990

Volume, Issue, Pages

$144 ; 1 ; 99-103$

Location: United States

Key words: Knowledge, Awareness, Incidence, Steroids Theory(s) applied: N/A

Summary

The paper reports on a survey of 2113 high school students' knowledge, perceptions and use of anabolic steroids. A 29 item questionnaire was used to assess general knowledge about steroids, awareness of risks and side effects, and incidence of use. Subjects were evenly distributed by sex and across grades 9-12. Results are compared for athletes and non-athletes.

Prevalence of steroid use was $6.5 \%$ percent in males and $2.5 \%$ in females. Five point five percent of athletes reported steroid use compared to $2.4 \%$ of non-athletes, with usage once again greater in males than females. The sports with the highest incidence of steroid use were American football and wrestling. Two percent of athletes stated that a coach or faculty member had suggested that they use steroids. Ten percent of respondents indicated they would use steroids to help in high school sport and $9 \%$ that they would use them to obtain an athletic scholarship. The most frequently cited sources of information on steroids were television (34\%), friends (27\%), 'muscle' magazines 6\% and physicians (4.8\%).

Problems associated with under and over reporting when using self-report methods should be considered when interpreting these findings.

\author{
Author Secondary Author(s) \\ Tricker, R. Connolly, D.
}

Title

Drugs and the college athlete: An analysis of the attitudes of student athletes at risk.

Publication

Journal of Drug Education

Publication Year

Volume, Issue, Pages

Sample: College athletes

Design: Cross-sectional survey (questionnaire)

$27 ; 2 ; 105-119$

Key words: Attitudes, Drug abuse, Risk factors

\section{Summary}

The study was intended to examine the relative importance of selected attitudinal factors that could be used to describe the profile of collegiate athlete who was 'at risk' for using anabolic steroids, human growth hormone and other banned substances. Five hundred and sixty three college athletes from 2 universities completed the King Drug in Sport Questionnaire. Subjects were classified as being 'at-risk' for drug use if they indicated they would use a particular substance to become a better athlete, if they could do so without getting caught or expressed similar such sentiment. Interpretation of findings is informed by the Theories of Reasoned Action and Planned Behaviour.

Thirty two percent of subjects reported lifetime use of marijuana, $8 \%$ use of anabolic steroids and $4 \%$ use of cocaine. Findings indicated that 'at-risk' student athletes in this study would use banned substances given the 'right' circumstances and that major influences on drug taking behaviour can be classified within the 3 principal areas outlined in the Theory of Reasoned Action. Subjects indicated that subjective norms, based on the influence of drug testing, peer influence and fear of detection are significant factors that influence the decision to use or not use banned substances. The implications of these findings for current and future doping education and prevention efforts are discussed. 


\title{
Author
}

Van Raalte, J.L.

\section{Title}

Perceptions of anabolic steroid users.

\section{Publication}

Journal of Applied Social Psychology

Sample: Bodybuilders, University students

Key words: Perception, Anabolic steroids,

\section{Summary}

Three experiments were conducted to examine the perceptions that three populations (steroid using athletes, non-using athletes, undergraduate non-users) have of a steroid using athlete. The study replicates and extends research conducted by Schwerin and Corcoran (1992). In experiment 1, subjects were provided with one of three variations of a written person description. Between conditions the story protagonist either (a) paid particular attention to his diet, (b) used the anabolic steroid Dianabol or (c) used cocaine for recreational purposes. Experiments 2 and 3 were identical, except for the use of additional person descriptions; a non-using athlete condition and a cheating bodybuilder condition. For all experiments, the Steroid Perception Questionnaire (Schwerin \& Corcoran, 1992) was used to determine subjects' perceptions of the target's arousal and aggression, intelligence, relaxation and tension reduction, sexual enhancement, social assertiveness and global positive effects.

Subjects in experiment 1 (steroid using athletes) viewed the steroid user in the story no differently from the diet conscious bodybuilder but more positively than the recreational cocaine user. Non-steroid using athletes in experiment 2 viewed the steroid using bodybuilder and the diet conscious bodybuilder or athlete similarly. In experiment 3, undergraduate students viewed the steroid user more negatively than both the diet conscious athlete and diet conscious bodybuilder. Psychosocial education programmes are discussed in light of the findings across the three studies.

\author{
Author Secondary Author(s) \\ Waddington, I. Malcolm, D., Roderick, M., Naik, R.
}

Title

Drug use in English professional football.

Publication

British Journal of Sports Medicine

Publication Year

2005

Design: Cross-sectional survey (postal questionnaire)

Theory(s) applied: N/A
Sample: Elite footballers

Key words: Attitudes, Recreational drugs

\section{Summary}

The article describes the use of nutritional supplements, knowledge of performance enhancing and recreational drug use, and experience and attitudes towards drug testing in English professional footballers. Data was obtained for 706 subjects by anonymous postal questionnaire, from an initial sample of 2863 (response rate $=25 \%$ ).

Supplement use was widespread, with $58 \%$ of subjects reporting use of vitamin pills and $37 \%$ using creatine. Players were more likely to consult with the club physiotherapist or fitness trainer than the club doctor for advice on supplement use. Thirty-four percent reported that they thought performance enhancing drugs were being used by some players and $6 \%$ stated that they knew someone personally that was using them. Whilst $65 \%$ of players reported that they had been tested for banned drugs within the last two years, $35 \%$ reported that they had not been tested and $60 \%$ believed it was unlikely that they would be tested within the next twelve months. The majority of players (73\%) indicated that drug testing was 'probably' or 'certainly' a deterrent to drug use. Players generally felt that punishment for drug use was 'about right' (59\%), whilst 25\% felt that it was 'not severe enough'. Footballers are drug tested less frequently than other professional athletes. The capacity of the existing drug testing programme to detect use of illicit drugs is questioned.

A low response rate may limit study findings. 


$\begin{array}{ll}\text { Author } & \text { Secondary Author(s) } \\ \text { Wagman, D.F. } & \text { Curry, L.A., Cook, D.L. } \\ \text { Title } & \end{array}$

An investigation into anabolic androgenic steroid use by elite US powerlifters.
Publication
Journal of Strength and Conditioning Research
Publication Year
1995
Volume, Issue, Pages 9; $3 ; 149-154$

Design: Cross-sectional survey (questionnaire)
Location: United States

Sample: Elite powerlifters

Theory(s) applied: N/A

Key words: Attitudes, Knowledge, Anabolic steroids

\author{
The
}

\title{
Summary
}

Elite US powerlifters were surveyed, using a postal questionnaire, to determine prevalence of and attitudes towards anabolic steroid (AS) use. Of the 26 participants deemed eligible for inclusion in the study, completed questionnaires were received from 15 (response rate $=60 \%$ ). Subjects were divided according to use of steroids; 10 self-identified as former or current 'users' and 5 as 'non-users'.

Users were more likely than non-users to believe that 'I would not be hurting anyone else if I decided to use AS' and that 'Taking AS is necessary if I am to be competitive in my sport'. In contrast, non-users were more likely to agree that 'I do not need AS to help me become the best athlete I can be'. All participants indicated that their competitors at national / international level were using AS. Two thirds of all respondents ( $60 \%$ users / $80 \%$ non-users) reported that current doping controls were ineffective. All non-users compared to $60 \%$ of users indicated that they would not want to compete if there were no doping controls. Eighty percent of users and $60 \%$ of nonusers stated they would prefer a situation in which no performance enhancing drugs were allowed and detection methods were $100 \%$ effective.

Small sample size and use of subjects drawn solely from the powerlifting population limit the extent to which findings may be generalised.

\section{Author}

Secondary Author(s)

Warner, D.C.

Schnepf, G., Barrett, M.S., Dian, D., Swigonski, N.L.

\section{Title}

Prevalence, attitudes and behaviours related to the use of nonsteroidal anti-inflammatory drugs (NSAIDs) in student athletes.

\section{Publication}

Journal of Adolescent Health

Sample: High school athletes
Volume, Issue, Pages $30 ; 3 ; 150-153$

Location: United States

Key words: Attitudes, Nonsteroidal anti-inflammatory

Publication Year

2002

\section{Summary}

This brief article describes prevalence and attitudes toward use of non-steroidal anti-inflammatory drugs (NSAIDS) in 604 male high school American football players. Administration of NSAIDS by intramuscular injection is a banned practice. Unfortunately, researchers do not provide details of the methods used by subjects to administer these drugs. Findings are of value in highlighting prevailing attitudes to and prevalence of NSAID use among high school American Football players. However, a limitation of this study is the low response rate (only 55\%) and the bias that could ensue owing to the fact that seventeen out of the thirt-five coaches contacted failed to return the completed surveys. Further, distrubuting questionnaires via the coach may lead to significant underreporting.

Seventy-five percent of subjects report using NSAIDS in the previous 3 months and $15 \%$ report daily use. Daily users were more likely to believe that NSAIDS improved their performance, to have decided independently to use them and used them to block pain before it occurred rather then as treatment for it.

Limitations to the study include using coaches to distribute questionnaires, which may introduce selection bias and failure to collect information on dosage and methods of drug administration. 
$\begin{array}{ll}\text { Author } & \text { Secondary Author(s) } \\ \text { Wright, S. } & \text { Grogan, S., Hunter, G. }\end{array}$

Title

Body-builders' attitudes towards steroid use.

Publication

Drugs: education, prevention and policy

Publication Year

2001

Volume, Issue, Pages

8; $1 ; 91-97$

Location: United Kingdom

Sample: Bodybuilders

Design: Cross-sectional survey (questionnaire)

Key words: Attitudes, Motivations, Anabolic steroids

Theory(s) applied: N/A

Summary

The study investigated attitudes and motivation for steroid use among bodybuilders and addressed implications for the development of drug education strategies. Five thousand questionnaires were distributed through two body building magazines, asking about motivation for training, attitudes toward and reasons for use of steroids. Replies were received from 135 readers, 59 of whom were steroid users. Subjects were mostly male, but the sample was otherwise diverse comprising subjects aged 18-68, who had been training for between 3 months and 47 years.

Users tended to emphasise the positive aspects associated with steroid use, which included enhancing training and demonstrating a commitment to body-building. Negative aspects of steroid use were played down and mostly attributed to ill-informed or ignorant practices. The majority of non-users viewed steroid use as cheating. Users and non-users generally agreed that steroids were used by many sports people, maximised hard training and were necessary for competing. Reasons for steroid use were often multiple, including to get bigger/more muscular, to compete, to speed up muscularity, for cosmetic reasons, overcome plateau or out of curiosity.

Subjects in the study were volunteers rather than being actively recruited, thus sample characteristics may be biased toward a particular personality type.

Author $\quad$ Secondary Author(s)

Title

Anabolic steroids and pre-adolescent athletes: Prevalence, knowledge and attitudes.

Publication

The Sport Journal

Sample: Pre-adolescent athletes

Design: Cross-sectional survey (questionnaire)
Volume, Issue, Pages $5 ; 3$

Location: United States

Key words: Attitudes, Knowledge, Prevalence

Theory(s) applied: N/A

Summary

A survey of 1553 pre-adolescent athletes (10-14 years) was conducted across 34 states in the USA, funded by the National Youth Sports Research and Development Centre. Using a 20 -item questionnaire, subjects were assessed for their knowledge of the effects of steroids use, sources of information on steroids, prevalence and attitudes toward steroids and accessibility.

Less than $1 \%$ of subjects reported current or previous use of anabolic steroids, with higher prevalence amongst males $(0.9 \%)$ than females (0.2\%). Reasons for use included to improve athletic performance, improve personal appearance and because of peer pressure. Sixty-six percent of athletes believed that steroids would not improve their performance and $90 \%$ stated that they did not need to use steroids to be successful in their chosen sport. Males were more inclined than females to report that steroids would improve performance and improve their chances of athletic success. The most common sources of information on steroids were books and magazines, followed by parents, coaches, trainers and lastly teachers. Thirty percent indicated they believed Olympic athletes used anabolic steroids to make the team, whilst $25 \%$ believed college athletes also used steroids to make the team. 


\section{Title}

Athletes' projections of anabolic steroid use.

\section{Publication}

Clinical Sports Medicine

Sample: College athletes

Key words: Beliefs, Estimated prevalence

\section{Summary}

In an attempt to overcome the problem of under-reporting associated with the use of self-report survey methods, this study asked subjects to estimate their competitors' anabolic steroid use level. The intention was to establish an estimate of steroid use that likely reflected the upper-boundary of actual use. Subjects were 1638 athletes from 5 NCAA Division 1 institutions.

Overall projected rate of anabolic steroid use was $14.7 \%$ for males and $5.9 \%$ for females. American football players reported the highest projected use rate (29.3\%), followed by track athletes $(20.5 \%)$ and baseball players (8.3\%). Only $2 \%$ of football players and $4 \%$ of track athletes believed that none of their competitors had ever used steroids. Sixty nine percent of football players reported that steroid use was 'a problem' or a 'very big problem' in their sport. Among female track athletes, $27 \%$ indicated that steroids were 'a problem' or 'very big problem' in their event. With the exception of women's hockey, $20 \%$ of respondents across all sports stated that steroid use had probably or definitely increased in the previous 4 years.

Despite asking subjects to estimate competitors steroid use rate, rather than their own, the survey response rate was modest (74\%), suggesting that some respondents were still unwilling to discuss drug use practices. Response rates for American football and track and field were lowest, while projections of use in these sports were highest. 
$\begin{array}{ll}\text { Author } & \text { Secondary Author(s) } \\ \text { Blouin, A.G. } & \text { Goldfield, G.S. }\end{array}$

Title

Body Image and steroid use in male bodybuilders.

Publication
International Journal of Eating Disorers

Publication Year

1995
Volume, Issue, Pages $18 ; 2 ; 159-165$

Location: Canada

Sample: Male bodybuilders

Key words: Anabolic steroids, Body image

Design: Case-control survey (questionnaire)

\title{
Summary
}

The relationship between body image, steroid use and sports participation was explored in 139 male athletes. The sample comprised 43 body builders, 48 runners and 48 martial artists, all of whom completed various questionnaires including the Anabolic steroid questionnaire, the Eating Disorder Inventory, Rosenberg's Self Esteem Scale and a Drive for Bulk Scale.

Bodybuilders reported lower levels of self-esteem, higher ineffectiveness and greater levels of perfectionism and interoceptive awareness than at least one, and sometimes both, of the other two groups. Bodybuilders also indicated elevated measures for bulimia, drive for thinness and drive for bulk compared to runners and martial artists. Steroid using bodybuilders reported significantly lower self-esteem, higher interoceptive awareness and maturity fears than non-using bodybuilders. Multiple linear regression analysis revealed that psychological and body image variables were significant predictors of steroid use. Significant independent predictors of steroid use were bulimia, drive for bulk and maturity fears. Psychological and behavioural characteristics of a subgroup of bodybuilders are similar to those of females with eating disorders.

Low response rate $(29 \%)$ limits the extent to which findings can be generalised to the wider bodybuilding population. It is not possible to ascertain whether the relationships identified herein are causes or consequences of steroid use, due to the cross-sectional nature of the study.

\author{
Author Secondary Author(s) \\ Brower, K.J. Blow, F.C., Young, J.P., Hill, E.M.
}

Title

Symptoms and correlates of anabolic-androgenic steroid dependence.

Publication

British Journal of Addiction

Publication Year

1991

Design: Cross-sectional survey (questionnaire)
Volume, Issue, Pages 86; 759-768

Location: United States

Sample: Male weight lifters

Theory(s) applied: N/A

Key words: Anabolic steroids, Correlates, Dependence

Summary

The study explored frequency and correlates of dependence on anabolic androgenic steroids (AAS) in 49 male steroid using weight lifters. Subjects were classified as either dependent or non-dependent using DSM-III-R criteria. The two groups were then compared on variables from four domains (physical, demographic, pharmacologic and psychological) believed to predict or correlate with dependence. Multiple regression analysis was used to predict dependence.

Twenty-eight subjects presented three or more symptoms of dependence and were thus classified as dependent, in accordance with DSM-III-R criteria. The remaining 21 subjects were grouped as non-dependent, though it is worthy to note that $94 \%$ of respondents reported at least one symptom associated with dependence. Comparison of dependent and non-dependent subjects revealed significant differences for pharmacologic and psychological variables only. Dependent users had taken larger doses of AAS and completed more cycles of use. They were also more likely to report not feeling big enough and more aggressive symptoms. Multiple regression analysis identified maximum dosage of AAS and feeling not big enough as significant predictors of number of symptoms of dependence. The importance of body image as a key motivator for AAS use and implications for prevention efforts are discussed.

A possible selection bias in sampling and failure to adopt methods to corroborate self-report measures are limitations to the present study. 
$\begin{array}{ll}\text { Author } & \text { Secondary Author(s) } \\ \text { Brower, K.J. } & \text { Blow, F.C., Hill, E.M. }\end{array}$

Title

Risk factors for anabolic-androgenic steroid use in men.

Publication

Publication Year

Volume, Issue, Pages

Journal of Psychiatric Research

1994

$28 ; 4 ; 369-380$

Sample: Male weight lifters

Design: Case-control survey (questionnaire)

Location: United States

Key words: Anabolic steroids, Risk factors, Body Image

Theory(s) applied: N/A

Summary

Risk factors for anabolic steroid use were investigated in a sample of 404 male weight lifters, selected from community gyms. After completion of a short, self administered questionnaire subjects were classified as either 'low risk non-user', 'high risk non-user' or 'steroid user'.

Group comparison revealed that on the continuum from low risk to high risk and from high risk to actual use, there was an increase in competitive bodybuilding, use of non-steroidal performance enhancers and steroid using acquaintances. Body image significantly distinguished subjects in the high risk group from the other two groups. Seventy-one percent of the high risk group felt they were 'not big enough' compared to $38 \%$ of steroid users and $21 \%$ of the low risk group. Stepwise multiple regression was used to select traits that best predicted how high risk subjects differed from those in the other two groups. After controlling for age, the best predictors of high risk status were feeling not big enough, knowing a steroid user, number of non-steroidal substances used, height and weight.

Some selection bias may have occurred as gyms were selected by convenience and systematic sampling of subjects did not occur. No information was gathered for females. Data collection was solely self report without corroboration by other techniques.

$\begin{array}{ll}\text { Author } & \text { Secondary Author(s) } \\ \text { Burnett, K.F. } & \text { Kleiman, M.E. }\end{array}$

Title

Psychological characteristics of adolescent steroid users.

Publication

Publication Year

1994

Design: Case-control survey (interview/questionnaire) Location: United States

Sample: Male weight trainers

Theory(s) applied: N/A

Key words: Anabolic steroids, Personality, Adolescents

Summary

The Millon Adolescent Personality Inventory (MAPI) and Profile of Mood States (POMS) were used to compare psychological characteristics of 24 adolescent steroid using weight trainers with 24 non-using weight trainers and 24 non-athletic control subjects. All subjects were male aged between 16-19.

Analysis of MAPI findings revealed that steroid users had significantly higher levels of forcefulness and impulsiveness and lower levels of cooperativeness than did non-athletes. For each of these measures, non-using athletes' scores fell between steroid users and non-athletes, but did not attain statistical significance. The authors suggest that adolescent steroid using athletes appear to be relatively similar to other adolescent athletes in terms of personality. POMS data indicated that users who were currently on a cycle of steroid use experienced higher levels of depression, anger, vigour and total mood disturbance than users not currently on a cycle.

Due to the cross-sectional nature of the research, it is not possible to determine cause and effect relationships between steroid use and the specified psychological characteristics. Small sample size precluded the use of rigorous statistical methods. 
$\begin{array}{ll}\text { Author } & \text { Secondary Author(s) } \\ \text { Evans, M. } & \text { Weinberg, R., Jackson, A. }\end{array}$

Title

Psychological factors related to drug use in college athletes.

Publication

The Sport Psychologist

Publication Year

1992

Design: Cross-sectional survey (questionnaire)

Theory(s) applied: N/A

$$
\text { applied: N/A }
$$

ssue, Pages $6 ; 1 ; 24-41$

Location: United States

Key words: Mood, Self-esteem, Illicit drugs

\section{Summary}

Psychological factors related to use of performance enhancing and recreational drugs were investigated in a sample of 377 male and 167 female college athletes. A questionnaire was used to gather demographic information, prevalence, intensity and duration of drug use and to explore the pressures felt by athletes regarding athletic and academic performance. In addition, subjects completed the Profile of Mood States (POMS) questionnaire and the Coopersmith Self-Esteem test. Differences between high / low quantity drug users and between males and females were assessed.

Due to low rates of usage for other drugs, analysis was restricted to alcohol, marijuana and barbiturates. High alcohol users (75\% percentile) scored significantly higher on POMS subscales of anger, fatigue and vigour than low / non-users. Interestingly, male low / non-users of alcohol scored higher on scores for vigour than did male high users, whilst the reverse was true for females with higher alcohol users scoring more on the vigour subscale than low / non-users. On the subject of stress, high alcohol users reported significantly more pressure from coaches to perform well, whilst low / non-user group reported higher levels of anxiety from maintaining academic grades. Barbiturate users recorded significantly lower self-esteem scores than non-users. No significant differences were found between marijuana users and non-users.

Due to the cross-sectional nature of research it is not possible to determine cause and effect relationships between drug use and specified variables.

Author

Kanayama, G

Title

Body image and attitudes toward male roles in anabolic-androgenic steroid users.

Publication

American Journal of Psychiatry

Sample: Weightlifters

Key words: Anabolic steroids, Body image

Summary

Using data gathered in previous research (Kanayama et al, 2003) this study sought to further examine the association between bodyimage and use of anabolic steroids in a small sample of heterosexual users $(n=48)$ and non-users $(n=41)$. All respondents completed questionnaires although four potential participants were excluded since their self-reported homo- or bi-sexuality may be linked to body image disorders. Questionnaires assessed self-esteem, attitudes toward male roles, body image, eating-related attitudes and behaviours and muscle dysmorphia. Findings highlighted few group differences, focusing on users reported greater muscle dysmorphia. Specifically, users were five times more likely to be 'Preoccupied with body size' (OR=5.5, $95 \mathrm{Cl} 1.7$ to 17.8) and were four times more likely to 'Always cover their body with clothes' (OR=4.1 95\% $\mathrm{Cl} 1.3$ to 13.0 ).

An important feature in the design was the recognition of short-term 'experimenters' from more prolonged, heavy users of AAS. However, these features of muscle dysmorphia were drawn from questionnaire items with unknown psychometric properties. The study highlights that body image concerns may be a stable trait in AAS users rather than a new feature linked to initial or recent use. 
Author Secondary Author(s)

Kanayama, G. Pope, H.G., Cohane, G., Hudson, J.I.

Title

Risk Factors for anabolic-androgenic steroid use among weightlifters: A case-control study.

Publication

Drug and Alcohol Dependence

Publication Year

2003

Design: Case-control survey (questionnaire)

Theory(s) applied: N/A

$$
\text { Theory(s) applied: N/A }
$$

Volume, Issue, Pages 71; 1; 77-86

Location: United States

Key words: Anabolic steroids, Risk factors

\section{Summary}

Risk factors for anabolic steroid use were assessed in 48 male steroid using weightlifters and 45 non-using matched control subjects. Researchers employed a number of questionnaires to identify differences between users and non-users including a Life Events Questionnaire, a modified rating scale for Attention Deficit Hyperactivity Disorder (ADHD), a childhood conduct disorder scale and a survey that explored subject's attributes when they first began to lift weights. In order that risk factors for use, rather than consequences of use, were identified, users responded to questionnaires according to their position before initiation of steroid use.

In support of the researchers' hypotheses, users reported poorer relationships with their fathers, lower self confidence about body appearance and higher rates of illicit substance abuse or dependence prior to steroid use. The authors comment that a poor relationship with one's father may in some way lead to deficits in 'body image' which individuals attempt to rectify through steroid use. Body image disorders may serve as both risk factors for and consequences of anabolic steroid use. Findings did not support a relationship between steroid use and rates of $A D H D$ or mood/anxiety disorders.

Limitations to this study include small sample size and possible selection bias in sampling methods. The study also fails to distinguish between causal and non-causal risk factors.

$\begin{array}{ll}\text { Author } & \text { Secondary Author(s) } \\ \text { Laure, P } & \text { Binsinger, C } \\ \text { Title } & \end{array}$

Adolescent athletes and the demand and supply of drugs to improve their performance.

\section{Publication}

Journal of Sports Science and Medicine

Sample: High school students
Publication Year

2005

Design: Cross-sectional survey (questionnaire)
Volume, Issue, Pages

2; 272-277

Location: France

Key words: Anabolic steroids, Adolescents, Enticement, Theory(s) applied: N/A

Summary

This study provides important evidence that a precipitating factor for drug use is athlete motivation (asking) supported by the enticement of local providers. A self-reported questionnaire was presented in two parts; (i) Drugs used to enhance performance and, (ii) Sources of drug supply and enticement. The questionnaire was distributed in the 2001-02 school year. From 6402 responses (48.9\% female, $46 \%$ return rate) $4 \%$ of French student athletes (average age 16.1 years) reported being 'enticed', with males (5.6\% ) over twice as commonly enticed as females (2.6\%). One in ten (10.3\%) athletes had been given prohibited substances from an average of two people (from friends, parents, family and doctors). Almost $50 \%$ of these athletes had paid for the supply. Findings also showed how suppliers especially 'target' high level athletes who are unsatisfied with their sporting results. Two arguments were used to entice; (a) better performance through improved strength, size and speed, and (b) combating pain and fatigue. Trusting the person doing the enticement was an important factor; half of users had not talked to their parents about being enticed.

With 42000 questionnaires distributed, the response rate may be questioned although the authors emphasise that only one third of the questionnaires were ever received by athletes. The authors emphasise that the relatively unrepresentative nature of the sample should be seen as only providing the details of specific types and patterns of behaviour. The adoption of an invalidated questionnaire is also problematic, even though the device was based on previous work. 


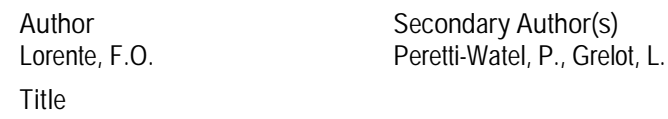

Publication

Addictive Behaviours

Sample: Sports science students

Key words: Cannabis, Sports performance

Summary

An 87-item questionnaire was used to examine sports practice and use of illicit drugs, especially cannabis (use of and motives), amongst 1152 students, drawn from 6 sports science universities in France (response rate 88\%). Researchers aimed to examine prevalence of cannabis use to enhance sportive and non-sportive performance and identify factors associated with both kinds of use.

Approximately $66 \%$ of respondents indicated use of cannabis at some point in their lifetime. Fifteen percent of males and $12 \%$ of females reported using cannabis to enhance sporting performance. Use of cannabis for sporting or non-sporting performance was highly correlated. A simultaneous equation model indicated that both kinds of cannabis use were endogenous: cannabis use to enhance sporting performance may lead to cannabis use to enhance non-sporting performance and vice versa. Cannabis use to enhance sporting performance was positively related to competitive level (increased use amongst national / international athletes compared to departmental / regional athletes) and sliding sports (windsurfing, skiing, snowboarding).

A number of variables that may impact upon the decision to use cannabis, such as ethnicity, socio-economic status or personality, were not included in the analysis.

\author{
Author Secondary Author(s) \\ Lucidi, F. $\quad$ Grano, C., Leone, L., Lombardo, C., Pesce, C
}

Title

Determinants of the intention to use doping substances: An empirical contribution in a sample of Italian adolescents.

Publication

Volume, Issue, Pages

International Journal of Sport Psychology

2004

$35 ; 2 ; 133-148$

Sample: High school students

Design: Cross-sectional survey (questionnaire)

Location: Italy

Key words: Doping, Intentions, Determinants

Theory(s) applied: Theory of Planned Behaviour

\title{
Summary
}

The study aimed to establish whether intentions towards the use of doping substances could be predicted by variables held within the Theory of Planned Behaviour (TPB) (attitudes, subjective norms, perceived behavioural control). Two additional variables were added to the model; past use of ergogenic supplements and a moral disengagement measure. The sample comprised 952 Italian high school students aged $14-20$ years ( $50 \%$ male)

Prevalence of illegal substance use was $5.2 \%$ for males and $1 \%$ for females. Findings indicated that TPB variables significantly predicted intentions to use doping substances. Attitudes towards doping were the strongest predictor of behavioural intentions, followed by social norms. The influence of perceived behavioural control on intentions was weak and barely significant. A relation was found between moral disengagement and intention to use doping substances. The author notes that the widely accepted norms of banning misconduct in sports, and the imperative of preserving one's health from damaging consequences of substance abuse, may not be accessible or effective with those individuals who have high moral disengagement levels, thus making these subjects more prone to doping agent abuse.

Formal methods of sampling were not employed in the present study, thus the possibility of sampling bias should be acknowledged. The relationship between intentions toward doping and actual use was not established. 


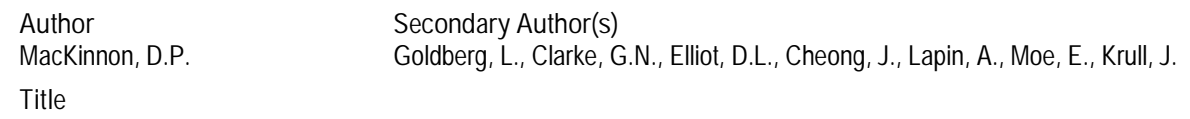

Publication Year

2001

2; $1 ; 15-28$

Prevention Science

Sample: High school athletes

Design: Cross-sectional survey (questionnaire)

Location: United States

Theory(s) applied: N/A

\title{
Summary
}

The study examined mediating mechanisms responsible for the effects of an intervention programme aimed at reducing intentions to use anabolic steroids, improve nutrition behaviours and increase strength training self-efficacy. The Adolescents Training and Learning to Avoid Steroids programme (ATLAS) was delivered to approximately 1500 male high school football players from 15 schools in Oregon and Washington, USA.

At 1 year follow-up, the programme effects on intent to use anabolic steroids were significantly mediated by perceived severity of anabolic steroid effects and reasons for using steroids. Interestingly, the mediated effect of reasons for using steroids was counterproductive, meaning that the increase in reasons for using steroids lead to greater intentions to use. For nutrition behaviours, peers as an information source, team as an information source and beliefs in media advertising significantly mediated programme effects at 1 year follow-up. The mediated effect of beliefs in media advertisements was a counterproductive effect. Programme effects on strength training self-efficacy were mediated by peers and team as sources of information, perceived severity of anabolic steroid effects and beliefs in media advertising, at 1 year follow-up. The finding that changes made to certain mediators was actually counterproductive to the overall aims of the programme, highlights the need for caution in selecting and intervening on mediators which form the basis of a prevention programme.

\author{
Author Secondary Author(s) \\ Miller, K.E Barnes, G.M., Sabo, D., Melnick, M.J., Farrell, M.P.
}

Title

A comparison of health risk behavior in adolescent users of anabolic-androgenic steroids, by gender and athlete status.

Publication

Sociology of Sport Journal

Publication Year

Volume, Issue, Pages

Sample: High school students

Design: Cross-sectional survey (questionnaire)

19; 385-402

Key words: Anabolic steriods, Risk factors, Health-risk

Theory(s) applied: N/A

\section{Summary}

Based on the Youth Risk Survey over, 16000 high school students completed self-reports of androgenic-anabolic steroid (AAS) use. The sample was nationally representative of ethnicity, although there was evidence of under-representation of some smaller ethnic groups. Almost 500 students reported using AAS, although sporting involvement (versus not) did not distinguish steroid use. However, AAS users were more likely to engage in other risk behaviours, suggesting that this forms part of problem behaviour syndrome. Among non-athletes AAS users were twice as likely to be female. Among Hispanic female athletes, steroid use was four times more common (versus non-athletes). Athlete users often engaged in higher levels of a range of risk behaviours, and were disproportionately represented by Hispanic groups. 


\author{
Author Secondary Author(s) \\ Papadopoulos, F.C Skalkidis, I., Parkkar, J., Petridou, E. \\ Title
}

Doping use among tertiary education students in six developed countries

Publication

European Journal of Epidemiology

2006

Volume, Issue, Pages

21; 307-313

Sample: College athletes

Design: Cross-sectional survey (questionnaire)

Location: Multi-national: Europe

Key words: Performance-enhancing drugs, Young people Theory(s) applied: N/A

Summary

A study of a broad range of doping involvement in a group not typically investigated, 'sports involved' tertiary education students. This sample was dominated by students over 21 years of age and analysis was based on the 2173 self-reports (1097 females).

Between $1.4 \%$ to $4.3 \%$ of respondents reported at least one use of physical performance enhancing drugs. The group average was $2.6 \%(n=68)$, with no international differences. However, national sample sizes were unequal, e.g., Italy $(n=71)$ and France $(n=212)$; Finland $(n=650)$ and Germany $(n=449)$. Anabolic steroid use was reported by 18 students. Multiple logistic regression emphasised that being a student in biomedical science reduced the likelihood of doping use. In contrast, taking supplements and having a doping peer were important independent predictors of increased risk of using doping substances. Further analysis highlighted that the greatest proportion of students using doping substances (9.9\%) were found in those both taking supplements and having a doping peer. However, findings based on comparisons with 18 people must always be viewed carefully.

The absence of some EU countries (e.g., Denmark, Sweden, Spain and the UK) weakens the generalisability of the findings.

Author

Secondary Author(s)

Schwerin, M.J. Corcoran, K.J., LaFleur, B.J., Fisher, L., Patterson, D., Olrich, T.

Title

Psychological predictors of anabolic steroid use: An exploratory study.

Publication

Publication Year

Volume, Issue, Pages

Journal of Child and Adolescent Substance Abuse

1997

$6 ; 2 ; 57-68$

Sample: Bodybuilders, Athletes

Design: Case-control survey (questionnaire)

Location: United States

Key words: Anabolic steroids, Psychological Predictors Theory(s) applied: N/A

Summary

Psychological predictors of anabolic steroid use are examined in 35 anabolic steroid (AS) using bodybuilders, 50 non-using body builders, 50 athletically active exercisers and 50 non-exercising individuals. Data were gathered using the Body Dissatisfaction Index (BoDI), the Upper Body Strength (UBS) component of the Body Self-Esteem Scale, the Social Physique Anxiety Scale (SPAS), and the Brief Fear of Negative Evaluation (Brief-FNE) scale. Multiple polychotomous logistic regression was used to identify factors that predicted membership of the AS-using bodybuilding group.

Three variables were found to be predictive of AS use; BoDI, UBS and age. For every one point increase in BoDI score (higher score = greater body dissatisfaction) the odds of being a non-user decreased, implying that increasing BoDI scores are more likely to indicate AS use. Similarly, higher scores of the UBS scale indicated a greater likelihood of AS use. AS using bodybuilders were more likely to be older than subjects from all other comparison groups. The importance of body image in understanding AS use is discussed.

Results and discussion are brief and lack in-depth analysis or examination of present and previous findings. A possible response bias due to low response rate (57\%) and use of only self report measures without corroboration by other means are limitations. 

Author
Secondary Author(s)
Striegel, $H$.
Simon, P., Frisch, S., Roecker, K., Dietz, K., Dickhuth, H.H., Ulrich, R.
Title
Anabolic ergogenic substance users in fitness-sports: A distinct group supported by the health care system.
Publication
Drug and Alcohol Dependence
Publication Year
Volume, Issue, Pages
2006
81; $11-19$

Sample: Fitness centre users

Key words: Ergogenic anabolic substances, Correlates Theory(s) applied: N/A

Summary

The study aimed to establish whether ergogenic substance users, especially anabolic steroid users, exhibit similar features to multiple substance users or whether they constitute a discrete group. One thousand eight hundred and two questionnaires assessing 'body data', 'social indicators', 'physical fitness', and drug use related constructs were distributed, of which 621 were included in data analysis (response rate $34.5 \%$ ). Subjects were recruited from fitness centres in Germany.

Ergogenic substance use was significantly higher in males (19.2\%) than females (3.9\%) and amongst bodybuilders (52.6\%) than weight lifters $(10.5 \%)$ or those practising fitness sports $(7.9 \%)$. Other factors correlated with ergogenic substance use were higher body weight, higher BMI, longer duration and more frequent fitness centre use. None of the social indicators (education status, family status, nationality) were associated with ergogenic drug use. Logistic regression analysis revealed a positive relation of anabolic ergogenic substance use with BMI, cocaine use, training years, training frequencies and bodybuilding and negative relations to alcohol consumption, A-level education and German nationality. Factors associated with general illicit drug use were alcohol intake, smoking, having a university degree and not having children. There was evidence to suggest that a high proportion of ergogenic drug users are supported by the public health care system, with $32 \%$ of users reporting that their usage was monitored by a physician.

The low response rate necessitates for a degree of caution in interpretation of findings.

Author

Tangen, J.O.

Title

To dope or not to dope. A study of the decision to use drugs in Norwegian sports.

Publication

Corpus, Pysche et Societas

Sample: Bodybuilders, Athletes, Students

Key words: Doping, Decision -making

Design: Case-control survey (questionnaire)

Publication Year

1997
Volume, Issue, Pages

4; 1; 41-65

Location: Norway

\section{Summary}

Drawing upon a range of disciplines, the study attempts to identify cultural, social and psychological processes that influence the decision to engage in doping behaviour. A questionnaire was developed based upon a heuristic model designed to summarize key factors in the decision making process. The sample comprised self-identified drug users, elite athletes, gym users and university students. According to questionnaire responses, subjects were separated into 'drug user' and 'non-user' groups for analysis.

Findings revealed a number of differences between users and non-users in terms of value-orientation, social position, social environment, sport milieu, sport capital, motives for training and structure of preferences. Users, for example, were more likely to report they experienced pressure to perform from rivals or team-mates rather than from themselves. One finding of particular interest was that users and non-users expressed similar sentiments with regard to a number of ethical issues in sport, such as match fixing or faking a penalty, differing only in their viewpoint regarding use of performance enhancing drugs.

The article provides an ambitious and comprehensive discussion of factors that may influence the decision-making process behind drug use in sport. Overall clarity and expression of these ideas is compromised however, possibly because English is not the author's first language. 


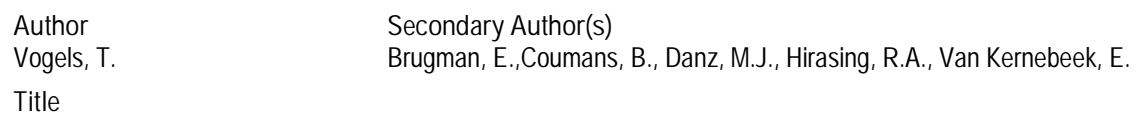

Publication Year

1996

Volume, Issue, Pages $3 ; 1 ; 39-48$

Sample: Gym users

Design: Cross-sectional survey (questionnaire)

Key words: Performance-enhancing drugs, Correlates Theory(s) applied: N/A

Summary

The study aimed to describe prevalence of performance enhancing drug (PED) use and the individual, social and cultural factors that contributed to their use, in a sample of gym members aged 16-25. Researchers' employed a body satisfaction scale to examine the impact of body image on drug use. Further questionnaires were used to explore social and cultural variables such as recreational drug use, knowledge and attitudes of peers about drugs and conformity/non-conformity with social or peer group norms.

Using multivariate logistic regression, the most significant predictors of PED use were 'being interested in PEDs', 'knowing other users' and non-conformity of the peer group'. In contrast to other research in this field (Brower et al 1994) findings did not indicate a strong relationship between PED use and body satisfaction. The importance of social and cultural factors in use of performance enhancing drugs is emphasised, especially with regard to education and prevention efforts.

No indication is given for subject's athletic/sporting ability or competitive status. Response rate to the present survey was quite low $(66 \%)$ and data collection was by solely self-report methods.

Author

Secondary Author(s)

Wichstrom, L.

Title

Predictors of future anabolic androgenic steroid use

Publication

Medicine and Science in Sports and Exercise

Publication Year

2006

Design: Prospective cohort (questionnaire)

Theory(s) applied: N/A

Key words: Anabolic steroids, Risk factors

\author{
Theory(s) applied: N/A
}

Summary

One of the only studies to use baseline self-reports to predict measures repeated again five years later (1994-1999). The sample comprised 2924 (1647 female) Norwegian high school students from 67 schools. Questionnaire items were drawn from established scales as part of the Young in Norway study. The random sample was representative of grades 7-12 (ages 12-20 years) and the overall return rate was $68 \%$.

Questionnaire subscales were taken from instruments with some evidence of psychometric testing. Anabolic-androgenic steroid (AAS) use was reported by $1.9 \%$ in baseline and $0.8 \%$ in the follow-up, indicating that this behaviour had only limited stability. Main findings were based on multiple logistic regression, showing that future AAS use was predicted by young age, male gender, previous AAS use, involvement in power sports and frequent alcohol intoxication (50+ times per 12 months). AAS use did not predict future emotional or behavioural problems other than reducing the risk of subsequent frequent alcohol intoxication. Results appear independent of attrition differences (based on gender, grade level, poor grades, domestic location and prediction for working manually at age 40), which heightens the generalisability of the findings. 
Anshel, M.

Title

Cognitive-behavioral strategies for combating drug abuse in sport: Implications for coaches and sport psychology consultants.

Publication

The Sport Psychologist

Sample: N/A

Key words: Cognitive-behavioural strategies, Prevention

ublication Year

1991

Volume, Issue, Pages

5; 152-166

Location: Australia

Summary

The author draws upon personal experience and relevant literature to discuss a number of cognitive and behavioural strategies that may be implemented by coaches or sports psychologists to prevent drug abuse by athletes. The article examines why previous attempts at controlling drug abuse in sport may have failed and argues that the role of a team coach or psychologist in preventing drug use has yet to be fully realised.

Cognitive strategies are those which aim to effect athletes' attitudes and behaviours through verbal and non-verbal communication. Anshel argues that these should appeal to the athlete's maturity, intellect, and need for self-actualisation and fulfilment, both individually and collectively as a team. A number of such strategies including, discussing ethical issues, teaching coping skills, providing educational opportunities, building self-esteem through skill development and being aware of an athlete's mental status are discussed. The primary objective of behavioural strategies is to shape the environment to control and influence subsequent behaviour. Behavioural strategies include avoiding boredom, developing and implementing plans of action, behavioural contracting, goal-setting and well organised drug testing.

A number of the strategies discussed here are not supported by empirical research, thus it is unclear whether such methods would be effective as part of a doping prevention intervention.

\section{Author}

Secondary Author(s)

Donovan, R.J.

Egger, G., Kapernick, V., Mendoza, J.

Title

A conceptual framework for achieving performance enhancing drug compliance in sport.

Publication

Sports Medicine

Sample: N/A

Design: Review / model development

Publication Year Volume, Issue, Pages 2002
$32 ; 4 ; 269-284$

Location: Australia

Key words: Conceptual framework, Prevention

Theory(s) applied: Health Belief Model, Protection Motivation Theory

\section{Summary}

A conceptual model to describe factors that influence an athletes attitudes and intentions to use (or not use) performance enhancing drugs is presented. Drawing upon behavioural science frameworks, previously employed in a range of health education settings (social cognition models, threat appeals and instrumental and normative approaches), the model outlines 6 variables believed to shape the decision to engage in doping behaviour: personality factors, threat appraisal, benefit appraisal, reference group influences, personal morality and legitimacy. Two additional 'market' factors (availability and affordability) that may facilitate or inhibit translation of attitudes and intentions into behaviour are also included.

The model predicts that likelihood of drug use is lowest when threat appraisal is high, benefit appraisal is mediocre, personal morality is opposed to drug use, legitimacy (of sanctioning bodies) is high, reference groups are disapproving of drug use and personality factors are resilient. The model is intended to provide anti doping agencies with a structured framework for strategic planning and implementing interventions.

Further research is required to improve understanding of athlete's attitudes regarding drug use and personality factors that effect drug use choices before the model can employed comprehensively. 

Author
Secondary Author(s)
Elliot, D.L.
Moe, E.L., Goldberg, L., DeFrancesco, C.A., Durham, M.B., Hix-Small, H.

Title

Definition and outcome of a curriculum to prevent disordered eating and body-shaping drug use.

Publication

Journal of School Health

Sample: High school athletes

Publication Year

2006
Volume, Issue, Pages 76; $2 ; 67-73$

Location: United States

Key words: Prevention, Adolescents, Risk factors

Theory(s) applied: N/A

Summary

This two-stage study began with pooling important factors to be included in a curriculum-based intervention (Athletes Targeting Healthy Exercise and Nutrition Alternatives - ATHENA). This is a sister study to the ATLAS study reported for boys. Initial data were drawn from 6 middle and 7 high schools $(n=1179)$ in Oregon, USA. In stage two, and based on a similar population, a randomised controlled trial was undertaken across 18 high schools ( $I=457, C=471$ pupils). Outcomes were based on questionnaire responses measuring mood, self-esteem, behavioural norms, perceptions of healthy body weight/size, media effects of women and societal pressures to be thin. Results consistently favoured the intervention over controls. Significant changes were found in the targeted risk factors and reduced on-going (in the previous 3 months), new use of diet pills and body-shaping drugs (amphetamines, AAS, sport supplements) and self-rated skill in strength training (all at least $P<0.05$ ). Nutrition and exercise behaviours and intentions for future drug use and for refusing unhealthy weight loss behaviours, and resisting unhealthy pressures from friends, all improved in the intervention (at least $P<$ 0.05).

Limitations include reliance on self-report, the short duration of the intervention and the low transferability of delivery quality.

\author{
Author Secondary Author(s) \\ Fritz, M.S. MacKinnon, D.P., Williams, J., Goldberg, L., Moe, E.L., Elliot, D.L.
}

Title

Analysis of baseline by treatment interactions in a drug prevention and health promotion program for high school male athletes.

Publication

Addictive Behaviours

Publication Year

Volume, Issue, Pages

Sample: High school athletes

Design: Randomised controlled trial (questionnaire)

30; 1001-1005

Key words: Prevention, Anabolic steroids

Theory(s) applied: N/A

Summary

This paper draws upon data gathered in previous research (Goldberg et al, 1996) to analyse baseline by treatment interactions for an intervention to prevent use of anabolic steroid in adolescents. Data were gathered from 3207 male high school football players, aged approximately 15 years.

Analysis revealed two baseline by treatment interactions, relating to knowledge and intention to use steroids, both of which served to improve the effectiveness of the programme. Specifically, individuals who knew less about steroids prior to the intervention learned more than those with greater initial knowledge. In addition, for those with a higher degree of intent before the programme, the intervention decreased their intentions to use steroids more than those with initially low intentions. 

Author
Secondary Author(s)
Goldberg, L.
Elliot, D., Clarke, G.N., Mackinnon, D.P., Moe, E., Zoref, L., Green, C., Wolf, S.L., Greffrath, E.,
Title
Miller, D.
Effects of a multi-dimensional anabolic steroid prevention intervention. The adolescents Training and Learning to Avoid Steroids
Publication
Journal of American Medical Association.
Publication Year
1996
Volume, Issue, Pages
$276 ; 19 ; 1555-1562$
Sample: High school athletes
Design: Randomised prospective trial (questionnaire)

Key words: Prevention, Adolescents, Anabolic steroids Theory(s) applied: N/A

\title{
Summary
}

A team-based education intervention was implemented to reduce anabolic steroid use amongst high school football players. Thirty four schools were randomly allocated to either an experimental or control condition. The intervention was administered to members of the school football team and comprised $7 \times 50$ minute class sessions lead by a coach or student team leader and 7 weight room sessions lead by research staff. The intervention addressed effects of steroids, nutrition and training alternatives to steroids, drug refusal role plays and anti-steroid messages. Subjects completed a self-administered questionnaire before and after the intervention and at 9 or 12 month follow-up.

At long-term follow up, experimental subjects had increased understanding of steroid effects, improved drug refusal skills, improved nutrition and exercise behaviours and reduced intentions to use anabolic steroids compared with controls. A number of other intervention effects relating to knowledge, attitudes, and individual and peer influences were noted, some of which persisted to long term follow-up. A team-based approach to improve adolescent steroid use behaviour and risk factors appears to be a promising avenue for future interventions.

Subject attrition and differences in control/experimental group baseline characteristics may have impacted upon findings.

\author{
Author Secondary Author(s) \\ Goldberg, L. $\quad$ Elliot, D.L.,Clarke, G.N., MacKinnon, D.P., Zoref, L., Moe, E., Green, C., Wolf, S.L.
}

Title

The adolescents training and learning to avoid steroids (ATLAS) prvention program. Background and results of a model intervention.

Publication

Archives of Pediatric and Adolescent Medicine

Sample: High school athletes

Design: Non-random controlled trial (questionnaire)

Publication Year

1996
Volume, Issue, Pages 150; 7; 713-721

Key words: Prevention, Attitudes, Anabolic steroids Theory(s) applied: N/A

\section{Summary}

The Adolescents Training and Learning to Avoid Steroids (ATLAS) intervention was developed to prevent anabolic steroid use amongst high risk adolescents. The intervention comprised $8 \times 1$-hour classroom sessions delivered by a coach or peer leader and 8 weightroom sessions lead by research staff. Two urban high schools participated; one received the intervention and one served as a control group. All subjects were high school football players, 56 from the experimental school and 24 from the control school. Mean age was 16 years. Subjects completed a 299 item questionnaire before and after the intervention to ascertain attitudes and intent to use steroids and other drugs, knowledge of drug effects, and diet and exercise related constructs.

Compared with controls, experimental subjects were significantly less interested in trying steroids, less likely to use them even if their friends did and less inclined to believe steroids were a good idea after the intervention. They also showed greater knowledge of nutritional supplements and alternatives to steroid use and improved body image.

Time and cost implications of such an extensive intervention programme may limit the extent to which similar initiatives could be coordinated on a national or international scale. 

Author
Secondary Author(s)
Goldberg, L.
Bosworth, E.E., Bents, R.T., Trevisan, L.

Title

Effect of an anabolic steroid education program on knowledge and attitudes of high school football players.

Publication

Journal of Adolescent Health Care

Publication Year

Volume, Issue, Pages

Sample: High school athletes

Design: Randomised controlled trial (questionnaire) $11 ; 3 ; 210-214$

Key words: Education, Attitudes, Anabolic steroids

Theory(s) applied: N/A

Summary

Researchers employed a pre/post experimental design to assess knowledge and attitudes towards anabolic steroid use in high school American football players. Subjects completed an anonymous questionnaire before and 2 weeks after a steroid education intervention.

Subjects were divided into three experimental groups. Group 1 received a lecture and 4 page handout, group 2 received the handout only and group 3 served as controls. Intervention content was based upon the current ACSM position statement.

Subjects receiving the presentation and handout (group 1) showed improved knowledge of 6 steroid effects (sterility, acne, cholesterol elevation, liver damage, cancer, aggressive behaviour) compared with controls. Knowledge improved on 3 steroid effect items (sterility, acne, cholesterol elevation) for subjects' receiving just the handout (group 2) as compared with controls. Group 1 subjects also had improved knowledge of 2 steroid effects (acne, aggressive behaviour) compared to those in group 2. Post intervention attitude scores increased for all groups, but intervention group scores were not significantly different from controls. The author notes that more in-depth exposure to the risks and complications of anabolic agents may be required to alter attitudes in adolescents.

\author{
Author Secondary Author(s) \\ Goldberg, L. MacKinnon, D.P., Elliot, D.L., Moe, E.L., Clarke, G., Cheong, J. \\ Title
}

The adolescents training and learning to avoid steroids program. Preventing drug use and promoting health behaviours.

Publication

Publication Year

Volume, Issue, Pages

Archives of Pediatric and Adolescent Medicine

2000

$154 ; 332-338$

Sample: High school athletes Design:Randomised controlled trial (questionnaire) Location: United States

Key words: Prevention, Anabolic steroids, Alcohol

Theory(s) applied: Social Learning Theory

Summary

The effects of a team-based randomised controlled trail aimed at reducing anabolic steroid, alcohol and other drug use in high school football players (aged 15-16 years) are described. Similar to previous studies (Goldberg et al 1996) the Adolescents Training and Learning to Avoid Steroids (ATLAS) program comprised classroom and weight-room based sessions, lead by coaches or peer leaders. The intervention programme addressed effects of steroids and other drugs on sports performance, alternatives to steroid and supplement use, nutritional advice and peer and media pressure resistance training. The intervention was conducted over 3 successive years, with 15 experimental schools and 16 control schools for each trial. Subjects' drug related attitudes, intentions and behaviours were assessed by questionnaire immediately before and after the intervention and at 1 year follow up.

At short-term follow-up, experimental subjects had lower intentions to use and actual use of anabolic steroids than control subjects. Intention to use steroids remained lower for experimental subjects at 1 year follow up. Experimental subjects more strongly believed that steroid use could be harmful and were less likely to believe advertisements for sports supplements and positive steroid use images at both follow-up periods. A number of positive intervention effects were noted for alcohol and other drug use, nutrition and exercise behaviour and peer/team influences

The financial costs associated with an intervention of this scale may limit the extent to which similar programmes could be implemented on a wider basis. 
$\begin{array}{ll}\text { Author } & \text { Secondary Author(s) } \\ \text { Goldberg, L. } & \text { Bents, R., Bosworth, E., Trevisan, L., Elliot, D.L. }\end{array}$

Title

Anabolic steroid education and adolescents: Do scare tactics work?

Publication

Publication Year

Volume, Issue, Pages

Pediatrics

1991 $87 ; 3 ; 283-286$

Sample: High school athletes Design: Randomised controlled trial (questionnaire)

Location: United States

Key words: Scare tactics, Knowledge, Anabolic steroids Theory(s) applied: N/A

Summary

The opinions of high school football players were assessed before and after two contrasting anabolic steroid education interventions. Group 1 received a balanced education programme, providing details of possible benefits and risks associated with steroid use. A second group received a programme focusing solely on adverse effects of steroid use (scare tactics). A third group served as controls.

Subjects receiving the balanced intervention significantly increased their agreement with 5 of 10 steroid effect risks, whilst those receiving the negative education programme showed no change in score on these factors. No changes were identified in attitudes toward personal steroid use in any of the 3 experimental groups. The author comments that strategies that primarily emphasise the adverse consequences of anabolic steroids are ineffective education models. Further investigation is required to identify initiatives that effect changes in attitude towards steroid use in adolescents.

Follow-up was conducted just 2 weeks after the intervention was implemented, thus it is not possible to determine whether effects persisted over time. The sample comprised solely male football players; therefore it is unclear how this intervention might affect those involved in other events or female athletes.

Author Secondary Author(s)

Goldberg, L. $\quad$ Elliot, D.L., MacKinnon, D.P., Moe, E., Kuehl, K.S., Nohre, L., Lockwood, C.M.

Title

Drug testing athletes to prevent substance abuse: Background and pilot study results of the SATURN study.

Publication

Publication Year

Volume, Issue, Pages

Journal of Adolescent Health

2003 $32 ; 1 ; 16-25$.

Sample: High school athletes Design: Non-randomised controlled trial (questionnaire)

Location: United States

Key words: Mandatory testing, Attitudes, Prevalence

Theory(s) applied: N/A

Summary

The effect of a mandatory, non-punitive, random drug testing programme for high school athletes was assessed. One hundred and fifty seven (experimental group: $n=95$ ) subjects aged approximately 15 years participated in the study. Participants completed a 121item questionnaire to assess beliefs and attitudes regarding negative and positive consequences of drug use and drug testing, norms among peers and authority figures, risk behaviours and perceived likelihood and efficacy of testing.

Past 30-day illicit drug use for athletes in the drug testing group decreased, whereas monthly use for control athletes increased from the beginning to the conclusion of the year. Whilst the programme was effective in reducing self-reported drug use, a number of changes in attitude towards drugs and drug testing were also noted, such that caution is required in interpretation of findings. At end of year follow-up, athletes in the drug testing group believed that drug use resulted in fewer negative consequences and indicated a preference for risky behaviours compared to those in the control group. In addition, subjects in the testing group also believed that there were fewer benefits of testing and that testing was less able to detect true drug use than control subjects.

A limitation to the study is that schools self-selected to the control or experimental condition, rather than being randomly allocated. 

Author
Secondary Author(s)
Grossman, S.J.
Smiley, E.B.
Title
APPLE: Description and evaluation of a substance abuse education and prevention program for collegiate athletes
Publication
The Journal of Primary Prevention
Publication Year
1999
Volume, Issue, Pages
20; $1 ; 51-59$

Sample: College athletes

Design: Intervention/evaluation (questionnaire / interview)

Location: Unlted States
Theory(s) applied: N/A

Key words: Substance abuse education, Prevention

Summary

The paper reports on the progress of the Athletic Prevention Programming and Leadership Education (APPLE) model for substance abuse education and prevention in university athletic departments. The model comprises 7 key 'slices': recruitment practices, expectations and attitudes, education, policies, referral and counselling, discipline and drug testing. Grossman et al (1993) provide a more detailed explanation of the APPLE model and its implementation. APPLE is the drug and alcohol education and prevention model for the National Collegiate Athletic Association (NCAA).

At the time of publication, 212 NCAA institutions had attended APPLE Working Weekend conferences, the starting point for implementing the APPLE model. Follow-up assessments indicate that institutions have been most successful in achieving goals in the areas of policy development, education and programming and addressing departmental attitudes and expectations. Factors that have characterised a lack of progress towards APPLE goals are time constraints, financial resources and administrative attitudes.

The effectiveness of the model in changing the drug and alcohol related attitudes and behaviours of student athletes is yet to be established.

\section{Author Secondary Author(s)}

Grossman, S.J. Gieck, J.

Title

A model alcohol and other drug peer education program for student athletes.

Publication

Journal of Sport Rehabilitation

Publication Year

1992
Volume, Issue, Pages

$1 ; 1 ; 337-349$

Location: United States

Sample: N/A

Design: Model development

Theory(s) applied: N/A

Key word
Summary

The authors describe a peer-lead alcohol and other drug (AOD) abuse prevention model for student athletes. The model focuses on generalised alcohol and drug use issues within athletic teams without specific reference to drug use for performance enhancement.

It is suggested that the college or university recruits an alcohol/drug prevention specialist to set up and administer the programme, but its successful operation is dependent upon institutional and administrative support at all levels, including athletic directors and coaches. Central to this model are peer elected team leaders that serve as an internal resource for team-mates experiencing AOD problems and as 'prevention specialists' for the team as a whole, assessing needs and organising education and prevention initiatives that are specific to their own team. Once elected, peer leaders are provided with training to develop knowledge of the subject area and leadership skills. A comprehensive evaluation plan should be designed prior to implementation of the programme and gather information from a variety of perspectives, including peer leader and their team-mates, coaches and athletic trainers.

The successful operation of this model depends greatly on the integrity and commitment of peer leaders and their ability to maintain cooperative and open relationships with team-mates once the programme is in operation. The authors do not provide an explanation of any theoretical grounding for the model. There is also a lack of specific and detailed guidelines for implementing this programme. 


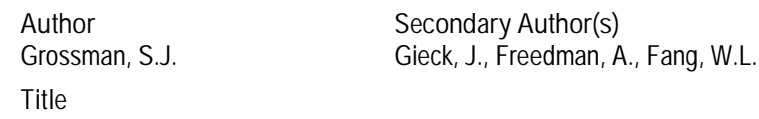

Sample: N/A

Design: Model development

Location: United States

Key words: Alcohol / drug prevention, Peer leaders

Theory(s) applied: N/A

Summary

The Athletic Prevention Programming and Leadership Education (APPLE) model aims to provide a framework for athletic departments to implement alcohol and other drug (AOD) abuse education and prevention initiatives for student athletes. The model is conceptually presented in the form of an apple, comprising 7 segments that each represent a key characteristic of the programme.

The 7 segments are: recruitment practices, expectations and attitudes, education and AOD programmes, policies, drug testing, discipline, referral and counselling. The education and AOD programme segment is believed to be the most important aspect of the APPLE model. The unique feature of education and AOD programmes informed by the APPLE model is the Student Athlete Mentor (SAM) scheme, wherein peer elected student mentors act as counsellors for team-mates and ensure education and prevention efforts are focused on the particular needs of the team they represent.

This initial presentation of the model served only to describe its development and key characteristics. Grossman and Smiley (1999) provide an evaluation of the programmes effectiveness after implementation across a number of universities.

\author{
Author Secondary Author(s) \\ Strelan, $P$.
}

Title

A new model for understanding performance enhancing drug use by elite athletes.

Publication

Journal of Applied Sport Psychology

Publication Year

2003

Design: Model development

Key words: Decision-making, Model, Elite athletes Theory(s) applied: Deterrence Theory

Summary

The Drugs in Sport Deterrence Model (DSDM) attempts to outline key factors that influence the decisions of elite athletes to use (or not use) performance enhancing drugs. The model is informed primarily by Deterrence Theory, an approach to understanding compliance with the law developed from criminological literature.

The model assumes that the decision to use performance enhancing drugs is well-informed, well-planned, rational and designed to maximise the athlete's best interests. The model consists of three main components: the costs of a decision to use (deterrents), the benefits associated with using, and specific situational factors which may impact on the cost-benefit analysis of using. Deterrents to drug use include legal sanctions, such as fines or suspension, social sanctions in the form of ostracism or disapproval by important others, self imposed sanctions, such as guilt or reduced self-esteem, and lastly health concerns in the form of negative side-effects associated with drug use. Benefits of drug use are material, (in the form of prize money or sponsorship) social (such as increased recognition from important others) and internal (factors related to satisfaction with high achievement). Situational factors include, professional status, type and availability of drug used and perceived legitimacy of sanctioning bodies.

The model is intended to guide further research and understanding in this field and has yet to be empirically tested. 


\author{
Author Secondary Author(s) \\ Trenhaile, J. Choi, H.S., Proctor, T.B., Work, P. \\ Title
}

The effects of anabolic steroid education on knowledge and attitudes of at-risk preadolescents.

Publication

Journal of Drug and Alcohol Education

Publication Year

1998

Volume, Issue, Pages

Sample: Preadolescent athletes Design: Randomised controlled trial (questionnaire) 43; $2 ; 20-31$

Key words: Attitudes, Knowledge, Anabolic steroids

Theory(s) applied: N/A

Location: United States

\title{
Summary
}

The effects of a steroid education intervention on knowledge and attitudes of 35 male preadolescent wrestlers was examined using an experimental pre/post test control group design. The intervention was conducted over $6 \times 30$ minute sessions on subjects relating to nutrition, social decision making, self-esteem training and psychological and physical effects of steroids. Subjects' steroid knowledge was assessed using the Anabolic Steroid Knowledge Questionnaire, and attitudes assessed using a modified version of the Drug Abuse Resistance Education program student questionnaire.

Data analysis revealed significant improvements in steroid knowledge for experimental subjects compared to controls. Statistically significant differences were also found on attitude scores, suggesting a positive improvement in attitudes for subjects in the experimental group. No differences were identified between experimental and control groups for self-esteem or peer resistance.

The study is limited by small sample size. No long term follow up was conducted, thus it is not possible to determine whether or not intervention effects persisted over time.

$\begin{array}{ll}\text { Author } & \text { Secondary Author(s) } \\ \text { Tricker, R. } & \text { Connolly, D. }\end{array}$

Title

Drug education and the college athlete: Evaluation of a decision-making model.

Publication

Publication Year

Volume, Issue, Pages

Journal of Drug Education

1996

$26 ; 2 ; 159-181$

Sample: University athletes

Design: Quasi-experiment (questionnaire)

Location: United States

Key words: Drug education, Decision-making

Theory(s) applied: N/A

Summary

The paper describes the evaluation of a10-week drug education and prevention programme (DEPP) for student athletes at Oregon State University (OSU) and Mid-Western University (MWU). A third cohort of university student athletes from Pacific North-Western University (PNWU) served as controls, making a total sample of 635 . The programme was a required module for all university athletes, and comprised guest speakers, discussion groups, written assignments and a group presentation. Subjects' knowledge about drugs, attitudes towards drug use, actual drug use and factors related to drug use decision making were assessed before and after programme implementation using the King Drug in Sport Questionnaire and the Decision Making Questionnaire.

Subjects from OSU showed significant improvements in drug related knowledge from pre to post test. Fewer students from OSU reported they would use steroids to help the team or felt they needed them to compete. Eighty-three percent of athletes at OSU agreed that the programme had had a positive impact upon them. There was evidence to suggest that athletes involved in major revenue generating sports (American football, basketball, baseball) perceived drug use and education differently from those in other sports. No significant differences in incidence and prevalence of drug use were identified across the 3 experimental groups. 


\section{Search terms}

i) 'attitudes', 'beliefs', 'knowledge', 'perspectives', 'opinions'.

ii) 'correlates', 'determinants', 'risk factors', 'precipitating factors'.

iii) 'education', 'intervention', 'model', 'prevention'.

\section{Inclusion criteria}

Articles that met the following criteria were included:

- Assessment of attitudes, beliefs or knowledge of performance enhancing drug use in sport (athletes, general public, coaches, physicians).

- Assessment of correlates, risk factors, or determinants of performance enhancing drug use amongst athletes (all levels of performance).

- Models, interventions or education programmes aimed at improving understanding or reducing use of performance enhancing drug use.

The search was limited to articles published in the English language since 1990. A detailed breakdown of the electronic search strategy follows. Manual searches of personal files and reference lists of primary research articles and reviews were also carried out. In addition, 24 national anti-doping organisations were contacted to identify internal publications, reports, surveys or other published material that would not be identified through conventional searching. Studies that investigated alcohol or other drug use (performance-enhancing or recreational) without specific reference to sports performance were excluded, and studies that only reported prevalence rates were also excluded.

\section{Search stages}

Sifting of search 'hits' consisted of three stages, as recommended by Lloyd Jones ${ }^{70}$. Papers were first reviewed by title, then by abstract and, finally by full text, excluding those at each stage that did not satisfy inclusion criteria. Searching revealed 12628 potentially relevant search 'hits'. In cases of uncertainty the paper was evaluated by two members of the research team and a consensus reached by discussion. 


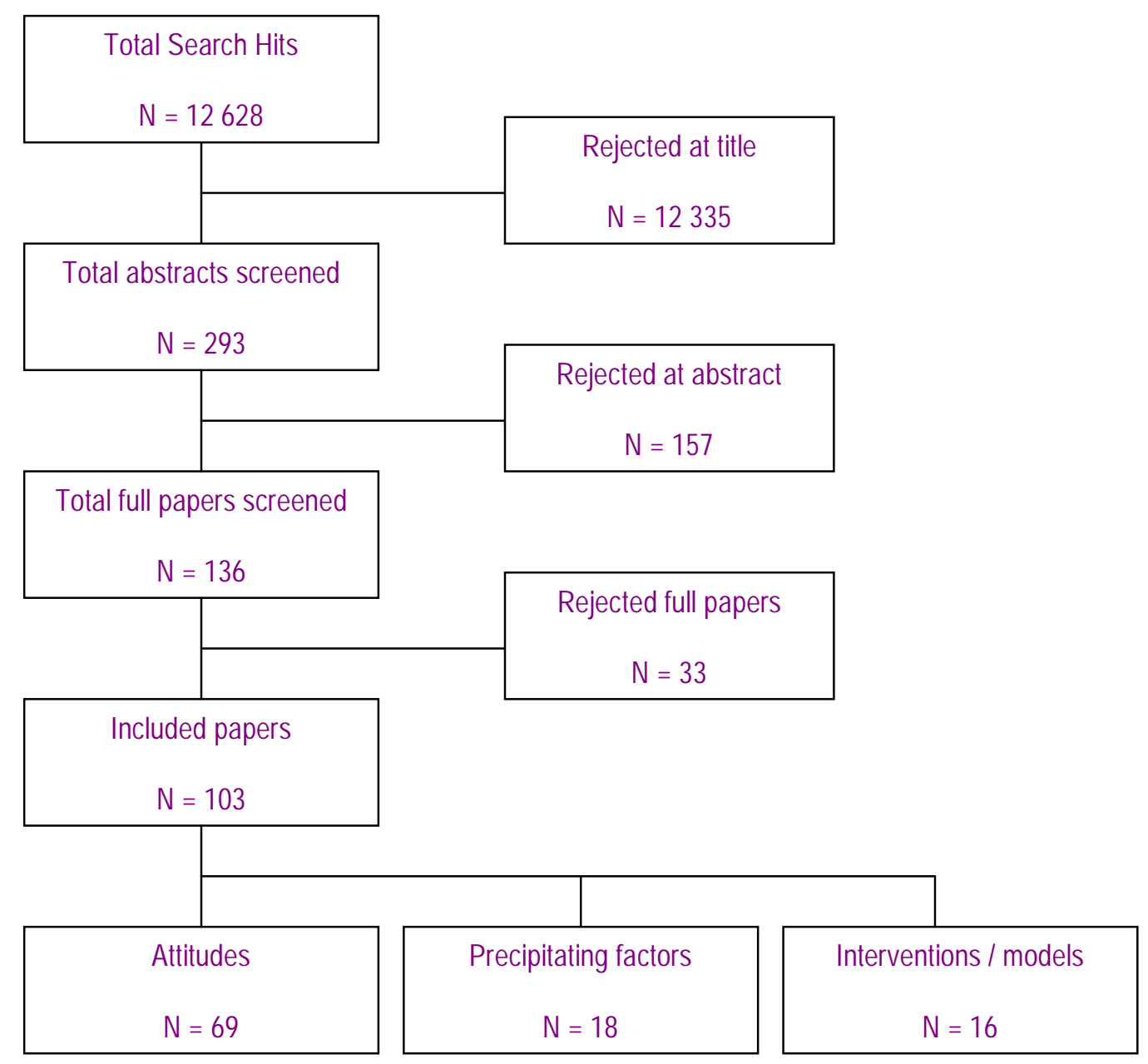

Figure 4. An overview of the electronic search strategy. 
Electronic search; Sources, Terms, Hits. Searched April 2006.

\section{Pubmed}

Limits: 1990 onwards, English language

Terms: doping AND attitudes

Hits: $\quad 58$

doping AND beliefs

doping AND knowledge

doping AND perspectives

doping AND opinions

performance enhancing drugs AND attitudes

performance enhancing drugs AND beliefs

performance enhancing drugs AND knowledge

performance enhancing drugs AND perspectives 2

performance enhancing drugs AND opinions 0

drugs AND sport AND attitudes 43

drugs AND sport AND beliefs $\quad 16$

drugs AND sport AND knowledge 34

drugs AND sport AND perspectives 2

drugs AND sport AND opinions 3

doping AND correlates 3

doping AND determinants 3

doping AND risk factors $\quad 35$

doping AND precipitating factors 1

performance enhancing drugs AND correlates 2

performance enhancing drugs AND determinants 0

performance enhancing drugs AND risk factors 5

performance enhancing drugs AND precipitating factors 0

drugs AND sport AND correlates $\quad 7$

drugs AND sport AND determinants 3

drugs AND sport AND risk factors $\quad 52$

drugs AND sport AND precipitating factors 1

$\begin{array}{ll}\text { doping AND education } & 87\end{array}$

doping AND intervention $\quad 10$

doping AND model 213

doping AND prevention 238

performance enhancing drugs AND education 21

performance enhancing drugs AND intervention 6

performance enhancing drugs AND model 23

performance enhancing drugs AND prevention 32

drugs AND sport AND education $\quad 74$

drugs AND sport AND intervention 32

drugs AND sport AND model 105

drugs AND sport AND prevention 157 


\section{Ingenta}

Limits: 1990 - 2006 Only, English Language

Terms: doping AND attitudes

Hits: 6

doping AND beliefs

doping AND knowledge

doping AND perspectives 14

doping AND opinions 1

performance enhancing drugs AND attitudes 1

performance enhancing drugs AND beliefs 1

performance enhancing drugs AND knowledge 5

performance enhancing drugs AND perspectives 3

performance enhancing drugs AND opinions 0

drugs AND sport AND attitudes 3

drugs AND sport AND beliefs 1

drugs AND sport AND knowledge 3

drugs AND sport AND perspectives 1

drugs AND sport AND opinions 0

doping AND correlates $\quad 21$

doping AND determinants 2

doping AND risk factors 2

doping AND precipitating factors 0

performance enhancing drugs AND correlates 1

performance enhancing drugs AND determinants 0

performance enhancing drugs AND risk factors 0

performance enhancing drugs AND precipitating factors 0

drugs AND sport AND correlates 0

drugs AND sport AND determinants 0

drugs AND sport AND risk factors 4

drugs AND sport AND precipitating factors 0

doping AND education 6

doping AND intervention $\quad 5$

doping AND model 1150

doping AND prevention 18

performance enhancing drugs AND education 0

performance enhancing drugs AND intervention 1

performance enhancing drugs AND model 8

performance enhancing drugs AND prevention 3

drugs AND sport AND education 3

drugs AND sport AND intervention 2

drugs AND sport AND model 3

drugs AND sport AND prevention 4 


\section{EBSCO (Academic search elite, Business source premier, Cinahl, Pre-Cinahl, Hospitality and Tourism index, Inspec, PsychArticles, PsychInfo, SportsDiscus, Lista)}

Limits: 1990 - 2006 only, English language, search for terms in Abstract

Terms: doping AND attitudes

Hits: 21

doping AND beliefs

doping AND knowledge

doping AND perspectives

doping AND opinions

performance enhancing drugs AND attitudes

performance enhancing drugs AND beliefs 2

performance enhancing drugs AND knowledge 8

performance enhancing drugs AND perspectives 2

performance enhancing drugs AND opinions 1

drugs AND sport AND attitudes $\quad 30$

drugs AND sport AND beliefs 4

drugs AND sport AND knowledge $\quad 33$

drugs AND sport AND perspectives 13

drugs AND sport AND opinions $\quad 7$

doping AND correlates $\quad 134$

doping AND determinants $\quad 10$

doping AND risk factors $\quad 6$

doping AND precipitating factors 0

performance enhancing drugs AND correlates 1

performance enhancing drugs AND determinants 0

performance enhancing drugs AND risk factors 2

performance enhancing drugs AND precipitating factors 0

drugs AND sport AND correlates 2

drugs AND sport AND determinants 1

drugs AND sport AND risk factors 16

drugs AND sport AND precipitating factors 0

doping AND education $\quad 62$

doping AND intervention $\quad 8$

$\begin{array}{ll}\text { doping AND model } & 7393\end{array}$

doping AND prevention $\quad 69$

performance enhancing drugs AND education 11

performance enhancing drugs AND intervention 2

performance enhancing drugs AND model $\quad 8$

performance enhancing drugs AND prevention $\quad 7$

drugs AND sport AND education 43

drugs AND sport AND intervention $\quad 14$

drugs AND sport AND model 18

drugs AND sport AND prevention $\quad 40$ 
Updated Search: 1st December 2006.

\section{Pubmed}

Limits: 2005 onwards, English language

Terms: doping AND attitudes

Hits: $\quad 10$

doping AND beliefs

doping AND knowledge

doping AND perspectives

doping AND opinions

performance enhancing drugs AND attitudes

performance enhancing drugs AND beliefs

performance enhancing drugs AND knowledge

performance enhancing drugs AND perspectives

performance enhancing drugs AND opinions

drugs AND sport AND attitudes

drugs AND sport AND beliefs

drugs AND sport AND knowledge

drugs AND sport AND perspectives

drugs AND sport AND opinions

doping AND correlates

doping AND determinants

doping AND risk factors

doping AND precipitating factors

performance enhancing drugs AND correlates

performance enhancing drugs AND determinants

performance enhancing drugs AND risk factors

performance enhancing drugs AND precipitating factors

drugs AND sport AND correlates

drugs AND sport AND determinants

drugs AND sport AND risk factors

drugs AND sport AND precipitating factors

doping AND education $\quad 29$

doping AND intervention $\quad 5$

doping AND model 4

doping AND prevention 0

performance enhancing drugs AND education 8

performance enhancing drugs AND intervention 0

performance enhancing drugs AND model 4

performance enhancing drugs AND prevention $\quad 7$

$\begin{array}{ll}\text { drugs AND sport AND education } & 17\end{array}$

drugs AND sport AND intervention 4

drugs AND sport AND model $\quad 5$

drugs AND sport AND prevention 25 


\section{Ingenta}

Limits: 2005 onwards, English language

Terms: doping AND attitudes

Hits: 6

doping AND beliefs

doping AND knowledge

doping AND perspectives $\quad 14$

doping AND opinions 3

performance enhancing drugs AND attitudes 1

performance enhancing drugs AND beliefs 5

performance enhancing drugs AND knowledge 1

performance enhancing drugs AND perspectives 3

performance enhancing drugs AND opinions 0

drugs AND sport AND attitudes 3

drugs AND sport AND beliefs 3

drugs AND sport AND knowledge 1

drugs AND sport AND perspectives 1

drugs AND sport AND opinions 0

doping AND correlates $\quad 21$

doping AND determinants 2

doping AND risk factors 2

doping AND precipitating factors 0

performance enhancing drugs AND correlates 0

performance enhancing drugs AND determinants 0

performance enhancing drugs AND risk factors 1

performance enhancing drugs AND precipitating factors 0

drugs AND sport AND correlates 0

drugs AND sport AND determinants 0

drugs AND sport AND risk factors 4

drugs AND sport AND precipitating factors 0

doping AND education 6

doping AND intervention 6

doping AND model $\quad 24$

doping AND prevention 0

performance enhancing drugs AND education 0

performance enhancing drugs AND intervention 1

performance enhancing drugs AND model 9

performance enhancing drugs AND prevention 3

drugs AND sport AND education 3

drugs AND sport AND intervention 2

drugs AND sport AND model 3

drugs AND sport AND prevention 4 
EBSCO (Academic search elite, Business source premier, Cinahl, Pre-Cinahl, Hospitality and Tourism index, Inspec, PsychArticles, PsychInfo, SportsDiscus, Lista)

Limits: 2005 onwards, English language, search for terms in abstract

Terms: doping AND attitudes

Hits: 18

doping AND beliefs

doping AND knowledge

doping AND perspectives

doping AND opinions

performance enhancing drugs AND attitudes

performance enhancing drugs AND beliefs

performance enhancing drugs AND knowledge

performance enhancing drugs AND perspectives

performance enhancing drugs AND opinions

drugs AND sport AND attitudes

drugs AND sport AND beliefs

drugs AND sport AND knowledge

drugs AND sport AND perspectives

drugs AND sport AND opinions

doping AND correlates

doping AND determinants

doping AND risk factors

doping AND precipitating factors

performance enhancing drugs AND correlates

performance enhancing drugs AND determinants

performance enhancing drugs AND risk factors

performance enhancing drugs AND precipitating factors 0

drugs AND sport AND correlates

drugs AND sport AND determinants

drugs AND sport AND risk factors

drugs AND sport AND precipitating factors

doping AND education $\quad 23$

doping AND intervention 4

doping AND model 3

doping AND prevention $\quad 28$

performance enhancing drugs AND education 0

performance enhancing drugs AND intervention 0

performance enhancing drugs AND model 0

performance enhancing drugs AND prevention 0

drugs AND sport AND education 9

drugs AND sport AND intervention 1

drugs AND sport AND model 0

drugs AND sport AND prevention 1 


\section{ZETOC and Web of Science}

Limits: 2005 onwards, English language

Terms: doping AND attitudes

Hits: $\quad 54$

doping AND beliefs

doping AND knowledge

doping AND perspectives $\quad 98$

doping AND opinions $\quad 21$

performance enhancing drugs AND attitudes 0

performance enhancing drugs AND beliefs 0

performance enhancing drugs AND knowledge 1

performance enhancing drugs AND perspectives 0

performance enhancing drugs AND opinions 1

drugs AND sport AND attitudes 0

drugs AND sport AND beliefs 0

drugs AND sport AND knowledge 0

drugs AND sport AND perspectives 0

drugs AND sport AND opinions 0

doping AND correlates 164

doping AND determinants 13

doping AND risk factors 14

doping AND precipitating factors 0

performance enhancing drugs AND correlates 2

performance enhancing drugs AND determinants 0

performance enhancing drugs AND risk factors 0

performance enhancing drugs AND precipitating factors 0

drugs AND sport AND correlates 0

drugs AND sport AND determinants 0

drugs AND sport AND risk factors 0

drugs AND sport AND precipitating factors 0

$\begin{array}{ll}\text { doping AND education } & 109\end{array}$

doping AND intervention $\quad 19$

doping AND model $\quad 24$

doping AND prevention $\quad 25$

performance enhancing drugs AND education 1

performance enhancing drugs AND intervention 0

performance enhancing drugs AND model 0

performance enhancing drugs AND prevention 1

drugs AND sport AND education 0

drugs AND sport AND intervention 0

drugs AND sport AND model $\quad 0$

drugs AND sport AND prevention 0 


\section{APPENDIX C: ETHICAL DECISION MAKING FRAMEWORK}

The information that follows frames the ethical reflection offered in Section 7.

a) Data gathering. The starting place of ethics is reflection on the situation. This means looking at the stakeholders who were involved in any situation and what their interests and needs are. Core to all data gathering is clarity about the expectations of stakeholders. Hence, gathering data can depend upon building up relationships with those involved in the situation.

b) Value Management. The second stage of ethical decision making is the identification and working through of the values involved. Different stakeholders will have different values, including personal, professional and public:

- Personal ethical values. These may be from a personal, cultural or religious belief system, focusing on everyday ethical practice

- Professional ethical values. Professional moral values can be seen as fundamental and procedural principles:

- Fundamental principles. Fundamental values of the profession include non malfeasance and beneficence ${ }^{14}$. These are very broad principles, meaning above all do no harm, but also do good. Interpreting these in the situation then becomes important. Another basic principle suggested by Beauchamp and Childress is respect for autonomy (self governance). This can be seen in two ways. Firstly, in a negative sense it involves not interfering with the freedom of the client to decide for themselves. Secondly, in a positive sense it refers to enabling the client to make their own decision. - Procedural principles. These are the important values which inform the professional's engagement with the situation, and are really instruments of the basic principles. Confidentiality is essential for respecting the autonomy of the client. Such confidentiality needs to be formally established. Informed consent is also essential to positive respect. In addition Beauchamp and Childress argue for cost-benefit analysis and risk-benefit analysis as ways of assessing consequences in the light of the basic principles.

- $\quad$ Public values. This might involve two areas. Firstly, the values of different groups or communities. Secondly, the values that underlie public life, including community, democracy, freedom and health.

c) Responsibility analysis and negotiation. Research in social policy and families has noted the importance of negotiating responsibilities in developing and maintaining ethical meaning. Finch and Mason ${ }^{33}$ concluded that a majority of families did not work from principles or any predetermined value base. Rather, they negotiated responsibility and through this developed ethical reputation and identity. A similar approach can apply to this phase of decision-making. Firstly, it involves identifying the stakeholders in any situation. Secondly, there is an analysis of the stakeholders in terms of power and responsibility. This enables a full appreciation of constraints and resources in the situation. Thirdly, responsibility can be negotiated. This does not simply look to the development of goods for all stakeholders. Rather, it accepts the premise of mutual responsibility and enables its embodiment. Hence, it enables a maximisation of resources through collaboration, and the development of ethical identity which can include all those involved. 
d) Responding. In making a response that takes account of the ethical issues the various possible options need to be reviewed in the light of the different values, bringing together value and principles, consequences, responsibilities and dialogue amongst the stakeholders. This also requires awareness of the constraints in any situation and the resources- maximised by collaboration.

\section{Virtue Ethics.}

Virtues ethics moves away from reliance on principles and assessment of consequences to the character of the person or the ethos of the community. Virtues are personal strengths or capacities that make up the character of the person, such as courage or integrity. Aristotle suggests that virtues are of the mean; that is they are not found in the extreme. Courage, for instance, lies between the extremes of foolhardiness and cowardliness. In this approach to ethics there is less concern for finding 'the right answer' and more for getting attitudes and virtues right, thus leading to the most ethical response.

\section{Moral development.}

Broadly moral psychology can be placed into either the stages view or the broader feminist view. The first of these argues that moral maturity develops in stages, moving from early dependence on others to determine ethical norms to greater ethical autonomy. The stage approach of Kohlberg 62 provides a way of assessing moral maturity. Gilligan 38 argues that moral psychology does not develop in this way, involving more a development in awareness and the capacity to respond in a creative and collaborative way. 